: $i^{2}$

;

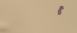

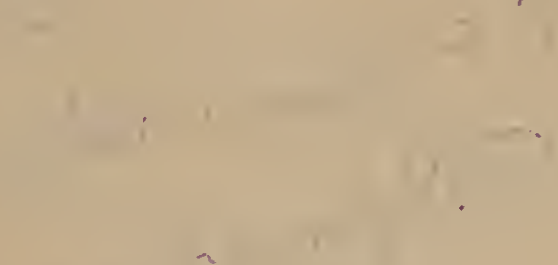

$\sqrt[12]{12}+2$ 




ARCANA ENTOMOLOGICA. 



\section{ARCANA ENTOMOLOGICA;}

012

\section{JEltustrattonts}

(1:

NEW, RARE, AND INTERESTING

\section{INSECTS.}

\section{BY J. O. WESTWOOD, F.L.S.,}

IIon. Mem. IIist. Soc. Quebec; Soc. Nat. I1ist. Boston, U.S.; Mem. Soc. Cas. Nat. Cux. Moscow; Physiogr. Soc. Lund; Soc. Roy. Scienc. Lille; Soc. Illst. Nat. Mauritjus; Snc. Curierr. and Philomat. Paris; Lit. I'hil. and Nat. IIist. Soe. Helfast, Richmond, Sheflield; Mem. Soc. Entomol. de France; Secretary Fint. Soc. Loudon, ke ke.

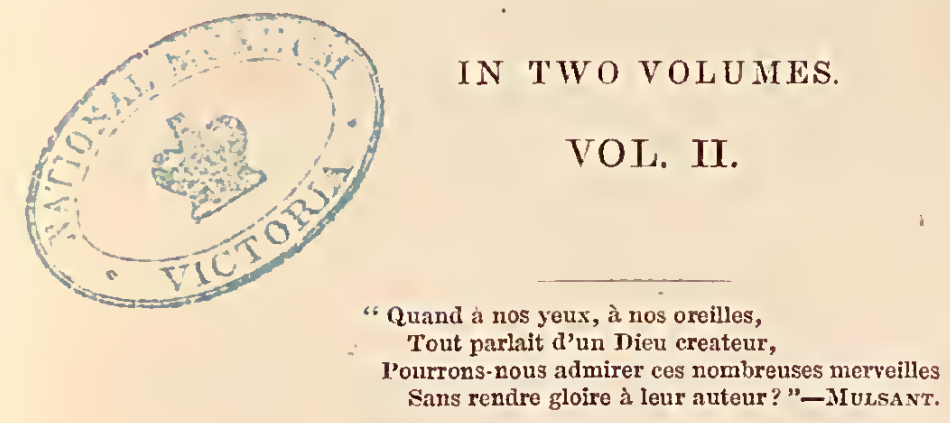

LONDON:

WILLIAM SMITH, 113, FLEET STREET.

Moccexty. 



\section{Sustematic :Arrangement}

OF THE

\section{ILLUSTRATIONS CONTAINED IN THE PRESEN'T VOLUME.}

\section{COLEOPTERA.}

Monograpit of tile Fanili Paussidas . . Plates 49, 50, 58, 68, 88, 89, 90, $91,92,93, \& 94$

Goliath Beetles of Africa . . . . Plates 67, $81, \& 96$ Two New Species of Yncs . . . . . . . Plate 73 Monograpi of the Genus Chiroscelis . . . . . . Plate 87 Longicorn Beetles of New Zealand . . . . . Plate 56 Longicorn Beitues of Africa . . . Plates 64, 69, 78, 84, 85, \& 86

HYMENOPTERA.

Mutillid of New Holland . . . . . . Plates 53 \& 54 Thynnidez of New Holland . . . . Plates 74, 75, 76, 77, $82 \& 83$ New Genera of Sphegide . . . . . . . Plate 65

ORTHOPTERA.

New Mantide . . . . . . . . . . . Plate 62 New Locustide and Gryllide. . . . . . Plates 63 \& 70 New Priasmide . . . . . . . . . . . Plate 61

HOMOPTERA.

Cicada imperatoria . . . . . . . . . . . Plate 51 New Cicade and Fulgoride . . . . . Plates 57 \& 71

\section{IEPIDOPTERA.}

Teinopalpus imperialis and Parrye • • • • . Plates 59 \& 60 New Holland Species of Papilio . . . . . . Plates 52 \& 68 Indian Species of Papilio . . . Plates 55, 66, 72, 79, \& 80 


\section{ERRATA.}

P. 5, 1, 21, rear " Palpi labialce articulis duobus ultimis aqualibus."

P. 20, 1. 25, add Note, In Tachypterts both the recurrent veins enter the 2nd submarginal cell as in Psamatha.

P. 42. The specics of Teinopalpus were captured at Darjeeling, au invalid station in the Himalayan Mountains, near the Nepaul frontier, about fifty miles from Dhamalagin, by Georgo R. J. Meares, Esq., by whom they were presented to Captain Parry.

P. 54. Transpose tho refereuees $\dagger$ and $\ddagger$ to the second and third foot uotes.

P. 84. Tamia (Sternotomis) Palinii, is the Lamia principalis, Dalm. Seh. Syn. I. iii. 1pp. p. 162 .

P. 103, 1. 17, add "The Genus Elurus, Klug, founded on two Ner World Species."

P. 115, for "Thynnus interruptus," read "Thynnus Leachiellus."

P. 124. "Aelurus mœrens," add, "alis fuseo parum tinctis, apice arex margicalis obseuriore."

P. 125. "Lamia Comes," is "2. cornutor, Fabr."

"Lamia prineeps," belongs to the "Sub-g. Zoographus."

P. 161. "Platyrhopalus suturalis," is " Pl. angustus, var." 

49.
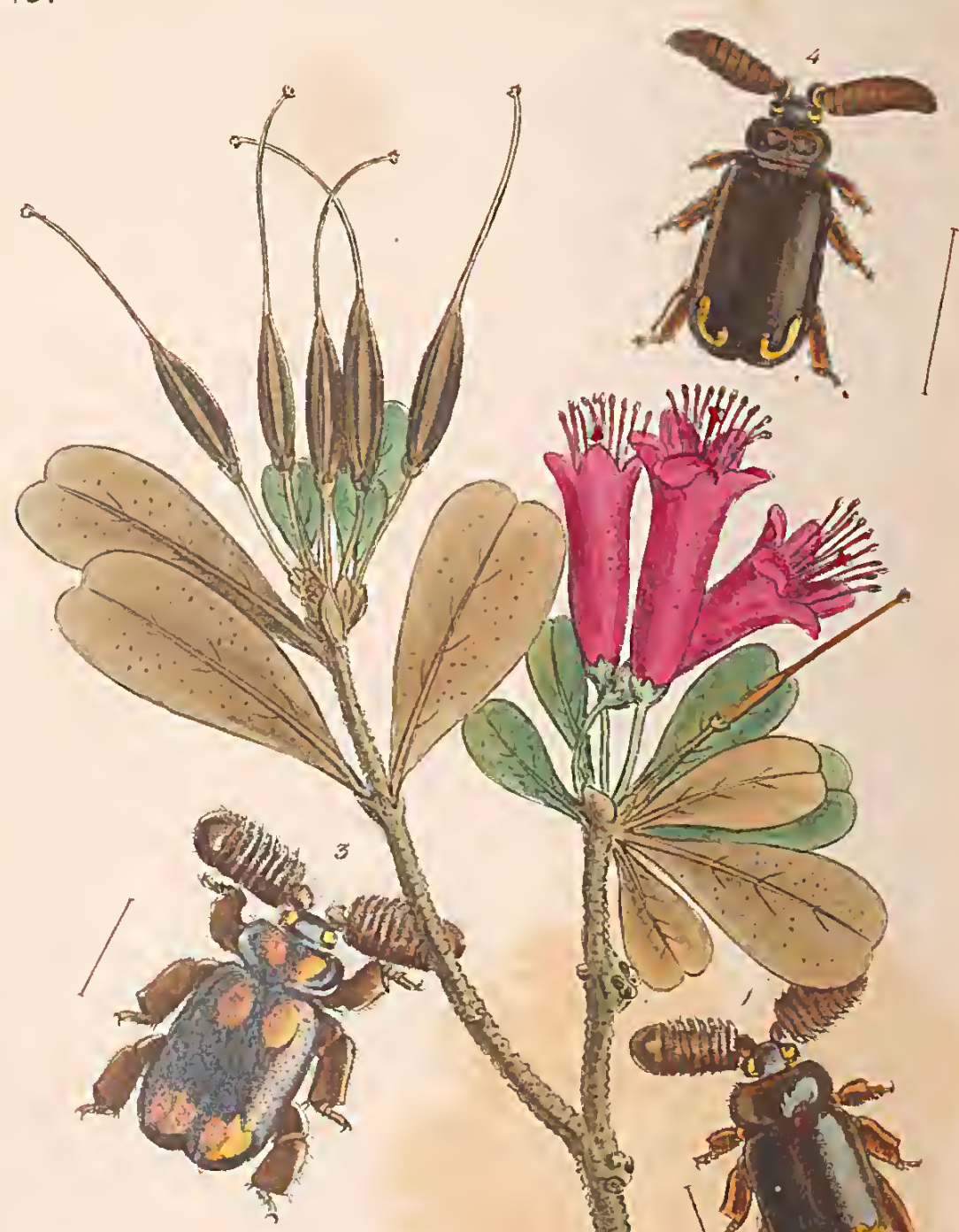

Hifle Wheses
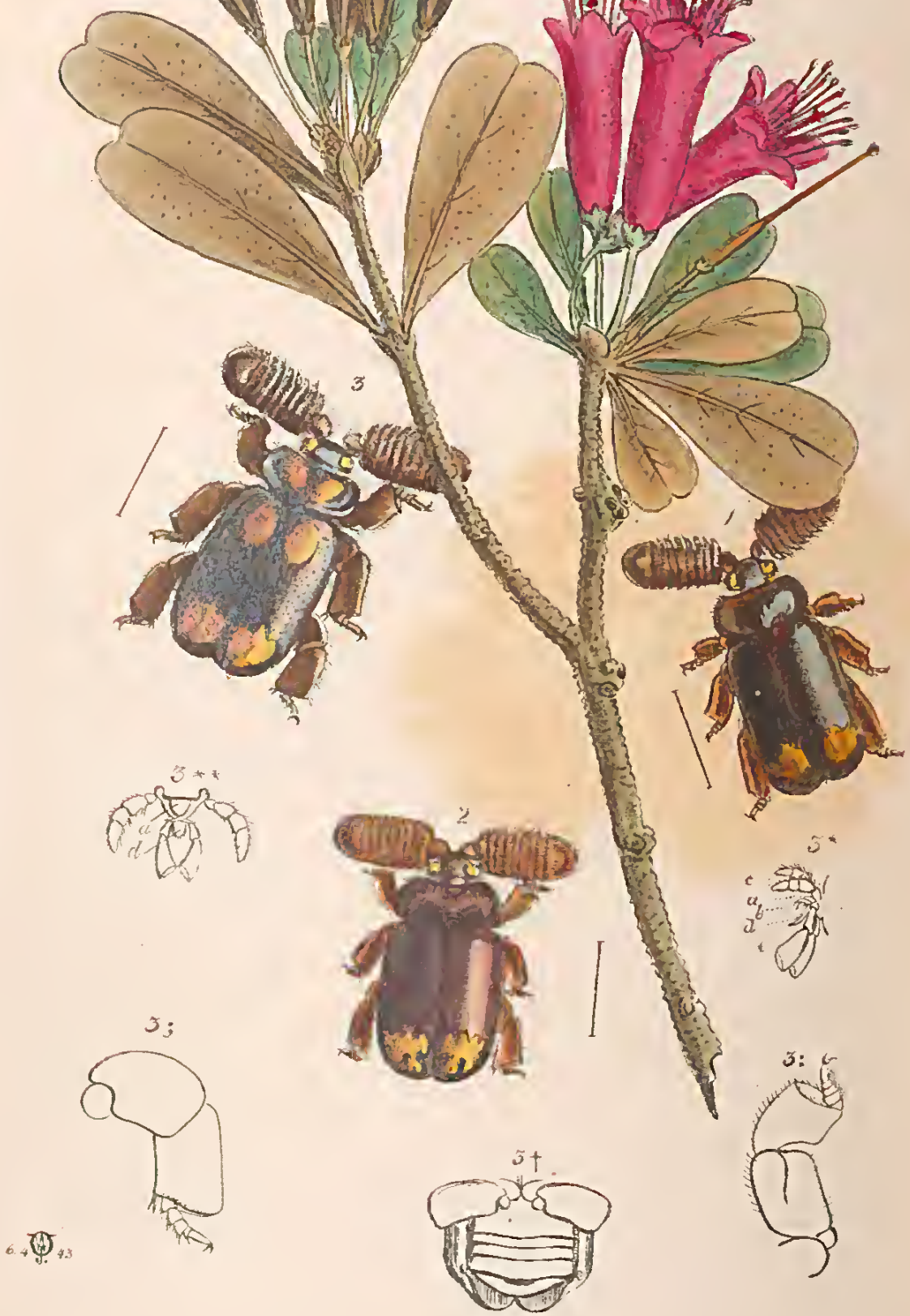

50.
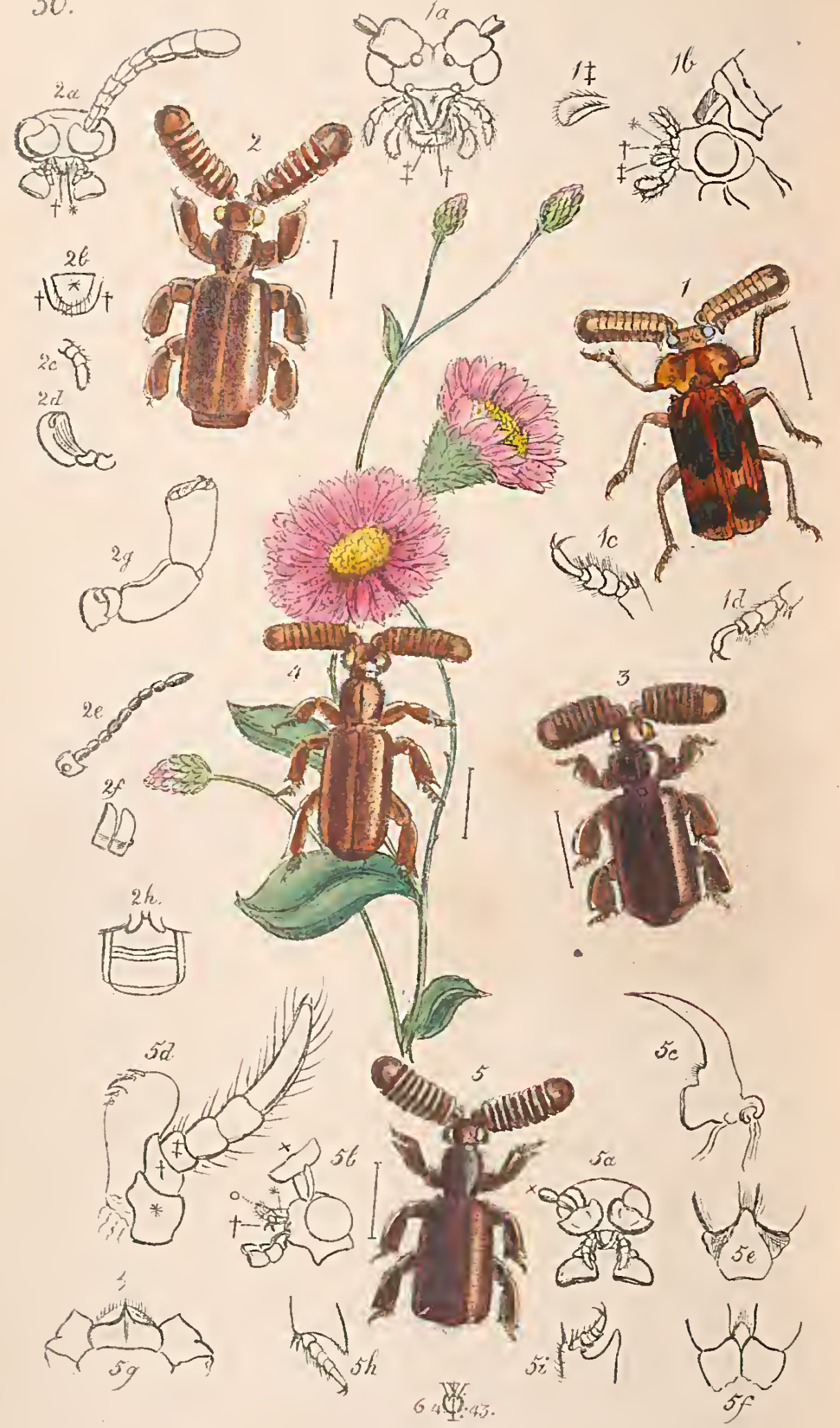


\title{
ARCANA EN'TOMOLOGICA.
}

\author{
PLATES XLIX AND L.
}

MONOGRAPH OF THE COLEOPTEROUS FAMILY PAUSSIDE.

\section{PART I.}

[HAving acquired, since the publication of my various memoir's on the family Paussidæ, which have appeared in the Transactions of the Linnean Society, vols. 16, 18, and 19; the 2nd volume of the Transactions of the Entomological Society, and the Entomological Magazine, vol. 5, mucl additional matter relating to these singular insects, as well as a considerable number of new species, of which no figures have yet been published, I have thought that a complete series of coloured figures of the entire family *, most of them redrawn with care for the purpose of this work, would be received with interest by entomologists.]

The family Paussidæ comprises a small assemblage of exotic coleopterous insects, varying from a quarter to rather more than half an inch in length, the species of which are of extreme rarity in collections (single individuals only of the greater portion being known); and at the same time so remarkable in their structure, that Latreille observed, "vainement chercherions nous dans tout l'ordre des Coléoptères un genre qui nous offie des caractères aussi bizarres, et aussi insolites que les Paussus." - Nouv. Dict. d'H. N. v. 25, p. 57 .

\footnotetext{
* The figures accompanying my monograph in the Linnxan Transactions, published twelve years ago, were uncoloured.

No. X111.-1st $\mathrm{MAY}, 1843$. 
The following are the chief characters of the family.

$$
\text { PAUssld K, Westw. (Paussili, Latr.; Paussides, Leach.) }
$$

Corpus oblongo-quadratum subdepressum, rigidum. Caput subtriangulari-globosum porrectum, collo instructum, antennx permagno crisse, difformes, articulis 2-10, articulo basali compresso, parte reliqua antennarum plus miruusve depressa: labrum corneum porrectum; manbuls falcatse cornex aeute; maxillw lobo satis magno, tenni, apice dentato, palpi maxillares nagni. Labium cornenn vel coriaccum: palpi labiales maximi. Tholax forma diversa. Elytra postice quadrata angulo externo apicali tuberenlo sepius instructo. Pedes subrequales breves compressi. Tarsi breves 5 -articulati in plurimis; articulis hand lobatis; basnli sxpius minnto. Abdomen thorace multo majus et elytris Jongius, e segmentis 4 constans, duobus intermediis multo brevieribus.

A short notice of the history of this family will show the great incrcase which has been madc in our knowledge of its contents. The genus Paussus was proposed by Cinnzens in 1775, in a short paper, in the Dissertationes Academice, in which he also described the genus Diopsis, and with which he terminated his entomological career. Of the former genus he knew only a single species. Thunberg, in 1781, described two more spccies of Paussus in the Swcdish Transactions, in which work the genus Cerapterus was described by Swederus in 1778. In 1798, Afzelius published an excellent paper on the Paussi in the Linncean Transactions, in which he described the then known species in detail, adding a new one. Donovan added several new species of Panssus, in the "Insects of India," and a new Cerapterus in his "Insects of New Holland," in which, for the first time, the relation existing between these two genera was noticed. One or two other species were added by Schönher, Dalman, and Fabricius; those introduced by the lastnamed author not belonging to the family. In the various nemoirs which I have pnblished, the number of species has been increased four-fold, excluding several now proved not to belong to the family; uamely, those constituting the genus Trochoideus WV. *, which, as shown by my dissections of one of the species published in the Transactions of the Entomological Society, is referable to the Endomychidae, and those which strictly belong to the sub-family of which Malaclius is the type + .

Of the habits of this family but little is known. The specimens of Paussus sphrerocerus captured by Afzelius at Sierra Leone, in the months of January and February, were taken in houses by

* 1. Paussus cruciatus, Dalm., found in Gum copal. ; 2. Troch. Dalmanni, Westw., from Madagascar; 3. Troch. Desjardinii, Guér, from the island of Mauritius; and of the Rev. W. W. Hope, from., from Colombia. A 5 th unnamed species is in the collection + 1. Paussus flavicomis, Fabricins probably identical with T. Amcricanus.

Guér.). 2. Paussus ruficollis, Fabricins (Megadcuterus flav., Westw.; Lajus eyaneus, chus vittatus, Say (Collops vittatus, 
night, falling upon the table from the ceiling, on the introduction of lights upon the table. They are slow and steady in their movements, and evidently of great rarity. I have received statements of sinilar habits exhibited by several other Indian and Javanese species; and Mr. Westermann states that the eight species of the family captured by hin, were all taken accidentally in louses by night, flying about wood, whence he conceives them to be nocturnal and xylophagous. (Silbermann, Rev. Ent. No. 3.) A species of Paussus was received by M. Dupont from Senegal, with the statement that it had been observed to crepitate like the Bombardier beetles; and M. Payen informed M. Lacordaire that the species which he had detected in the Moluccas and isles of Sunda, possess the same power. (Lacord. Introd. ii., p. 57.) M. Verreaux at the Cape of Good Hope, and Mr. George MacLeay in New Holland, liave detected species of Paussidx in ants' nests: the latter having also observed that the species of Cerapterus captured by him crepitates. A new species of this genus has recently been received by Mr. Hope from Port Philip, with the observation that it had been found under dried cow-dung as well as under the loose bark of trees.

Afzelius also states that in looking at one of his specimens of Paussus sphærocerus (remarkable for the globular, glossy, and pale-coloured club of its antennæ) in the evening, and happening to stand between the light and the box in which it was enclosed, so that his shadow fell upon the insect, ho observed, to his great astonishment, tho globes of the antennæ, like two lanthorns, spreading a dim phosphoric light. He adds, however, that he was "prevented from ascertaining the fact by reiterated experiments," as his specimen died. Nay not the reflected light falling upon the semipellucid livid-coloured balls of the antennæ give them the described appearance? Or, may it not be accounted for precisely in the same manner as the light emitted by the shining moss mentioned in Loudon's "Magazine of Natural History," (No. xv. p. 463 ,) by the late Mr. Bowman?

In their geographical distribution the insects of this family, hitherto known, are natives of the old world, if we except the species represented in plate 50, f. 2 , which $\mathrm{Mr}$. Miers has brought from Brazil. The others are from tropical and southern Africa, India, the islands of the Indian Ocean, and New South Wales; and one from the Balkan Mountaius in Turkey.

The relations of thesc insects with other Coleopterous families 
has been the subject of much doubt. Afzelius separatcd Paussus into a distinct fifth section of the Coleoptera, on account of its antenis, observing, however, that they bear so much natural resenblance to Clerus, that their proper place in the systematic arrangement will be next to that genus. With Clerus, howcrer, as well as with Cerocona, (a relation proposed by Fabricius), or Silpha and Hispa (as suggested by Swederus), the Paussida can scarcely bc said to possess a single point of relationship. Latreille united them, with many other groups, into a great tribe, under the name of Xylophaga, intermediate between the Rhynchophorous and Longicorn beetles. That they are related to some of the insects introduced amongst the Xylophaga, appears to me to be the case; but, as las been proved by various latcr writers, many of the Xylopliaga belong to the great division Necrophaga, into which the Paussidæe must also enter, together with the Trogositidæe ancl aberrant Cucujidae, "which last may perhaps be regarded as possessing the greatest affinity with the Paussida, more particularly when wo notice the depressed bodies, the formation of the antenna, and especially the pentamerous tarsi in many of the gencra of that fanily, such as Catogenus, Clinidium, Rhysodes," \&c. Such is the opinion I expressed in my first Paper in the Linnæan 'Transactions, after a very cxtended series of dissections of a great number of allied genera of Xylophaga, and such is still my opinion notwithstanding Mr. MacLeay (Annul. of S. Afr. p. 73) has given me credit for having been the first to suspect the affinity of Cryptopliagns witlı the Paussidæ, without having however expressed myself very clearly upon the subject. It would indeed have been extraordinary had I done so, becauso I never entertained such an opinion.

Mr. MacLeay also states that Trochoideus certainly leads off from the Paussidx to Myrmecoxenus, Cherr., Cryptophagus, \&c., but in my opinion the first-mentioned genus does not possess the sliglitest relation with any of the others; in like manner the relationship asserted by $\mathrm{Mr}$. MacLeay to exist between the Paussidæa and Psclaphidæ, seems to me equally unnatural, since no two groups can possess fewer points of resemblance in common. "It would have been quite as natural to assert the relation of the Paussidæe with the Ozenæ, for the latter crepitate, their bodies are polished, and their elytra furnished with tubercles at the outer posterior angles, as in the Paussi."

The resemblance thus pointed out by me in 1838 has appeared 
to Dr. Burmeister to be of greater importance than I felt and still feel disposed to accord to it, since in a very philosophical memoir published by him in Guérin's Mlagasin de Zoologie, 1841, he has endeavoured to prove that the Paussida are nearly related to the Carabidx, and especially to the Ozænæe, considering them as a group annectent to the Carabida, in the same manner as tho Gyrinida are attached to the Dyticirla.

My observations on the grounds on which Dr. Burmeister lias deduced this relationship will be given in treating on the genera Paussus and Platyrhopalus, an examination of which led Dr. Burmeister to arlopt these views.

The following is a synoptical table of the genera belonging to the family :-

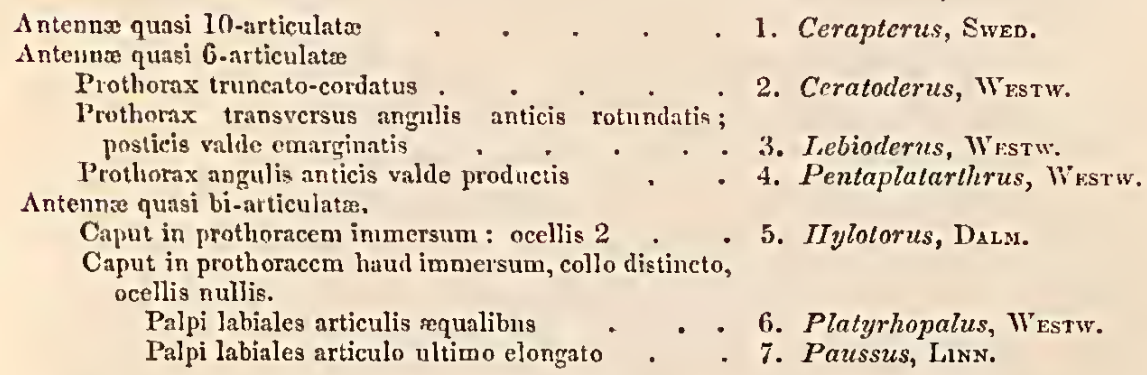

The various relations existing amongst the species of these different genera, do not appear to me to allow of their arrangement either in a linear or eircular series in our present limited knowledge of the family. Mr. MacLeay, adopting a series of relations pointed out by ne in the Linuean Transactions, proposed to arrange them in a circle by eommeneing witl the Paussi, thence passing to Platyrhopalus, P. Mellii leading to Cerapterus latipes, Cerapterus MacLeaii to Pentaplatarthrus, by which last he returns to the Panssi with a bipartite prothorax. Considering the discovery of a circular arrangement of the species of a group to be the cssential proof of its being natural, it follows that all other genera which appear to belong to the family must be rejeeted, "since, if inserted in the above cireular series, they appear to interrupt it." I consider it lowever unquestionable that Ceratoderus, Lebioderus, and Hylotorus, are as truly Paussideous as Cerapterus or Pentaplatarthrus, and to be groups as high in the importance of their characters as either of those genera which Mr. MacLeay himself admits.

I shall aecordingly describe the genera in the order given in the above table, without wishing it to be considered as their natural 
linenr series; and shall, under each group, notice the relations it appears to bear to the rest.

\section{CER APTERUS, Swederus.}

Corpus depressum abdomine elytrisque latis. Caput subtringgulare postice collo brevi cylindrico instructuu : oculiglobosi valde promiuuli : antenua capitis fronte insertæ pubescentes perfoliatas 10-articulatix, capite cun thorace paullo lougiores, articulo Imo compresso sublunari, reliquis ]atis depressis, 2-9 transsersis, nltino fere quartam parten antenna constituente apige rotundato: Jabrum mandibula et maxilla parva. Palpi elongati inaquales; labinles crassiores. Filytra al angulos posticos externos tuberculo instructa. Tarsi breves 5 -articulati in cxcavatioue apicali tibiaruu eapius recepti, articulis basalibus crassioribus subtus sctosis.

In the number of the joints in the antcnnæe this genus stands alone in the family; several of its species, however, exhibit relations with some of the gencra; thus Cerapterus latipes bears a strong resenblance to Platyrhopalus Mellii ; the Australian specics in their simplc-formed prothorax and gencral form rescmble the species of Paussi in which the prothorax is not bipartite, whilst C. Westermanni in its slender legs and dilated prothorax resembles Lebioderus.

Mr. MacLeay, in 1838, in his Paper on this genus, (introduced into Dr. Smith's Illustrations of the Zoology of South Africa, in consequence of a new specics of the genus having becn brought from thence by that naturalist) published figures of four species. I am now enabled by the kindness of several correspondents to describe as many as nino distinct specios, which may be divided into the following subgenera.

\section{Sub-Genus I.-CERAPTERUS (stricte sic dictus).}

Prothorax latissimus, lateribus rotundatis, antenna latissinæe lateribus serratis articulo ultimo maximo. Elytra abdomen tegentia. Tibir latissimæ (in C. 4-maculato bicalcarntæ, in reliquis ccalcarates). Scutellum mediocrc.

Specres I.-Cerapterns latipes. (Plate 49, fig. 1.) " C. piceus ; clytris macula apicali flarescente subrotunda antice quadridentata postice lobata ; antennis rufis articulo ultimo in tubcreulo ad basin elevato." MacL. [Palpis labialibus sec. figuras Swederi articulo ultimo paullo securiformi]. Long. corn., sec. fig. Swed. lin. 6.

Iabitat in Oriente.

Srs.-Swéderus, Kongl. Vetensk Acad. \&c. t. 9, 1788, p. 203, pl. 6, f. 1. Westw. Linn. Trans. 16, p. 669, and 18, p. 582. MacLeay Ann. Soc. Afr. pl. 4, fig. inf. sinistr.

The above description and the accompanying nigure are taken from Mr. Macteay's memoir above referred to, as that gentleman now possesses the original and still unique specimen described by Swederus, who states that it came from Honduras; but Donovan, on the authority of General Davies, the original possessor of the insect, stated it to be a native of Bengal. Mr. MacLeay further adds, "Thorax capite duplo latior medio posticeque utrinque foveo- 
latus, antennse lateribus convergentibus serratis, articulo ultimo quatuor præcedentibus simml sumptis longiore. Elytra thorace vix latiora. Tibiæ rufre latissimæ apice haud spinosæ."

Spec1es 1I.-Cerapterus ITorsfieldii. (Plate 49, fig. 2.) C. picens thoraee antice emarginato, elytris macula apicale flavescente laud rotundata, literam ' $\Upsilon$ quodammodo simulantc, palporum l:ubialinm alticu lo ultimo valde se euriforme. Long. eorp. lin. $5 \frac{1}{3}$.

1Iibitat in insula Jara, Dr. Horsfield. In the colleetion of the East India House, and Mr. Melly.

Srn.-Cerapterus IYorsfieldii, Westw. Linn. Trans, v. 16, p. 672, v. 18, p. 583. MacLcay op. eit. tab. 4, fig. sup. dext.

Nr. MaeLeay from a careful comparison between Dr. Horsfield's and Swederus' inseets, gives the following characters as distinctive of this species.

"Caput nigro-piccum, antennis rufo-fcrrugincis lateribus parallelis vix serratis articulo basilari lobato, ultimo quinque precedentibus simul sumptis longiore: thorax eapite triplo latior, postice utrinquc subfoveolatus. Elytra thoraee latiora : tibia rufxe apiee haud spinosa."

Speeres IIl.-Ceraplerus quadrimaculatus. (Plate 49, fig. 3, and details.) C. picco-niger, nitidissimus, prothorace (antice viso) subemarginato maculis duabus magnis obseure rufescentibus, clytris tenuissime punctatis maeulis duabus magnis ovalibus prope scutcllum alterisque duabus apicem versus majoribus antice et postice lobạtis rufo-fulvis. Long. corp. lin. 5.

Habitat in insula Jara, D. Westermann.

Srx.-Cerapterus quadrimaculatus, Westw. Trans. Linn. Soc. v. 18, p. 583.

Fig. $3 *$ represents the trophi seen laterally in situ ; $a$ is the labrum, $b$, the two mandibles, $c$, the maxillary palpi, $d$, the elongated labium, and $e$, the labial palpi, which are moderately securiform. Fig. $3 * *$ represents the same organs seen in front similarly lettered. Fig. 3: represents one of the fore feet; and 3; one of the hind ones, the tibire in the four latter bicalearated, and the tarsi 5 -jointed; and fig. 3 t the under side of part of the body, the deflexed podex being risible beyond the terminal joint.

\section{Sub-Gexus I1._ORTHOPTERUS, Westw.}

Thorax latus (capite haud duplo latior): antenno longiores sublate plana lateribus subrectis, articulo ultimo mediori. Elytra abdomen tegentia: tibire spina apicali intus instruetre.

Speeles I. (IV.)-Cerapteras (Orthopterus) Smithii. (Plate 49, f. 4.) C. nigro-piceus subnitidus, elytris macula fulva notatis, thorace latioribus et fere quintuplo longioribus. Long. corp. lin. $7 \frac{1}{2}$.

Habitat, South Africa witlin the tropic of Capricorn.

Syn.-Cerapterus Smilhii, MacLeay op. cit. p. 74, pl. 4, fig. sup. sinistr. Westw, Linn. Trans. v. 18, p. 583, and Entomol. Mag. 5, p. 502.

This is the largest species in the family. A unique specimen was "eollected by Dr. Smith, and described and figured by Mr. MacLeay in the "Annulosa of South Africa," from which work my figure and description are derived. 


\section{Sub-Genus III.-ARTHROPTERUS, MucLeay.}

Caput thorace haud augustius : thorax subquadrntus antiee paullo latior. Antennæ sublatæ lateribus haud serratis articulo ultimo mediocre. Elytra angusta abdomine breviora: tibis apice bicalcarate angulo opposito acuto: scutellum ninutum: tarsi intra tibiarum apies haud contractiles.

Species I. (Y.)-Cerapterus (Arthropterus) MIacLeaii. (Plate 50, fig. 4.) C. rufobrunneus antennarumu lateribus haud serratis; thorace subeonvexo postice angustiore angulis antieis rotundatis postieis aeutis diseo in medio vix canaliculato; elytris oblongo-quadratis; pedibus rufo-brunneis. Long. eorp. lin. $4 \frac{1}{2}$.

Habitat in Nova Hollandia. In Mlus. D. MacLeay.

Srx.-Cerapterus MacLeaii, Donovan, Ins, of New Holland, Plato 3, MacLeay, op. eit. pl. 4, fig. iuf. dext. Westwond. Linn. Trans. 16, p. 672, 18, p. 384, and Ent. Mag. 5, p. 503.

Mr. Francillon's unique specimen of this species is now in Mr. Macleay's possession, from whose figure in the work above quoted mine is copied.

Spreifs II. (VI.)-Cerapterus (Arthropterus) Hopii. (Plate 50. fig. 5, and details) C. pieeus punctatus nitidus setosus, elytris brunnen-piceis, antennis pedibusque nigricantibus prothorace ovali postice truncato medio leviter eanaliculato, antenuarum lateribus subserratis. Long. corp. lin. $4 \frac{1}{2}-5$. Habitat in Nova Hollandia. Port Philip. Mus. D. Hope and Parry.

Several specimens of this species have been received by the Rev. F. W. Hope, from New Holland; namely, one from Mr. W. S. MacLeny, who has suggested the specific name which I lave adopted above; and others, flom Port Philip: the latter captured under bark, and beneath dried cow-dung.

Fig. $5 a$ represents the head fiom tho front, and $5 \delta$ sideways, * being the labium, t the mandibles, and o the maxillary palpi; the labial palpi, as seen in these figures, are of large size, and very securiform. $5 c$ is one of the mandibles highly magnified; $5 d$ one of the maxillæ, also highly magnified, with the basal portions separately indicated for more easy comparison with the figures to appear in the subsequent plates of this monograph; $5 e$ represents the labium and basal joints of the labial palpi as seen from the outside of the mouth, the former of small size, and scarcely extended beyond the extremity of the basal joint; in $5 f$ (as seen within the mouth) the two basal joints are seen to be soldered together, forming the inside of the labium ; $5 \mathrm{~g}$ represents the mentum, which in this species forms, with the two lateral pieces, a kind of collar, enclosing the labium and base of the labial palpi; $5 h$ represents one of the hind feet; and $5 i$ a fore-foot: all having two apical spines, and the tarsi, especially in the hind feet, clearly seen to be 5 -jointed. 


\section{Sub-Gevus 1V.-PHYMATOPTERUS, Testw.}

Depressiusculus : caput thoraco augustius : prothorax cordato-truncatus medio longitudinaliter imprcssus: antennæ lata serratæ: clytra oblongo-quadrata ad angulum externum apicalem tuberculo instructa. Tibiæ latw interno ad apiccn bicalcaratse, angulo externo opposito rotundato. Tarsi distinctc 5-articulati.

Species 1. (VII.)-Cerapterus (Phymatopterus) picezs. (Platc 50, flg. 3.) C. piceus tenuissime puuctatus antennis pedibusque rufo piccis, capite thorace-minori angulis pono oculos acute procluctis. Long. corp. lin. 5.

Habitat in Nova Hollandia. In Mus. D. Curtis et Gory.

Cerapterus ( Phymatopterus) piceus. Westw. in Ent. MIag. 5, p. 503 ; Linn. Trans. v. xviii. p. 584.

Cerapterus MTacLeaii?. Westw. in Trans. Ent. Soc. vol. ii. p. 95, pl. x. fig. 7 .

\section{Sur-Genus V.-HOMOPTERUS, Westw.}

Depressiusculus : caput thorace paullo latius verticc depresso; palpi maxillarcs parvi graciles articulo ultimo longiori attcnuato; labiales 3-articulati articulo Imo. minuto 2 do. latiori brevi angulis apicalibus acutis, 3 tio. maximo valde securiformi ; antenna longiores subplana anticè subserrata, margine postico subcontinuo; thorax cordato-truncatus; elytra elongatoquadrata. Femora et tibire latissimse, has apice ecalcaratio et pro receptiono tibiarnm excavatce. Tarsi breves articulis intermediis subtus sctosis.

SPEcIEs I. (VIIl.)-Cerapterus (Homopterus) Brasiliensis. (Plnte 50, fig. 2, and details.) C. fulvo-rufescens, tenuissimo punctatus oculis albidis, vertico dcpresso, thorace intra augulos posticos utrinque foveolato. Long. corp. lin. $3 \frac{1}{3}$.

Sxx.-Cerapterus Brasiliensis, Miers's MS. Westw. in Linn. Trans. vol. xviii. pl. 39, fig. $\mathrm{C}$, $a$, and $b$.

"This insect was caught on the Corcavado Mountain, near Rio Janeiro, by a negro whom I employed."-Miers's MSS.

The unique species above alluded to is now in Mr. Miers's rich collection of South American insects.

Figure $2 a$ represents the head seen in front, * being the labrum, and t the mandibles, which are more higlly magnified in $2 b ; 2 c$ is one of the maxillary palpi ; $2 d$ one of the labial palpi seen laterally; $2 e$ one of the antennæe seen laterally, showing the broad compressed basal joint and the depressed terminal joints; $2 f$ are two of the intermediate joints of the antenne; $2 \cdot g$ one of the fore legs; and $2 h$ the abdomen seen from beneath.

\section{Sur-Genus VI.-PLEUROPTERUS, Westw.}

Caput thoraco duplo augustius. Antenne elongata subplanx, articulo 2do. extus in angulum acutum producto. Palpi elongati, labiales articulo ultímo crassiori vix securiformi. Labinm maximum rigidum. 'Thorax clytrorun latitudine lateribus marginc elevato, posticc valde siuuato utrinquo in auriculam producto. Elytra oblongo-quadrata, basi bicostata; Pedes elongati graciles tibiis bicalcaratis tarsisque latis, subtus setosis 5-articulatis articulis $1 \mathrm{ct} 4$ nuinoribus.

Species 1. (IX.)-Cerapterns (Pleuropterus) Westermanni. (Plate 50, fig. 1, and details.) C. rufo piccus haud nitidus; clytris nigris postice cruce rufescenti notatis, basi bicostatis, disco lougitudinaliter sub impicssis apice mfescentibus. Long. corp. lin. $4 \frac{1}{3}$.

Habitat in Iusula Jara. In Mus. D. Westermanni.

I lave named this species after the distinguished entomologist to whose kindness I am so greatly indebted, for sending me his unique 
specimens of this and several other species of the family, from Copenlagen, for my examination.

Figure $1 a$ represents the head in front, and $1 b$ sideways - * bcing the labrum, + the mandibles, and + the labium; $1 c$ is one of the fore fcet; and $1 d$ one of the hind ones.

The plant represented in Plate 49 is the beautiful Javancse Rhododendron retusmm, and in Plate 50 is figured the Rhodanthe Manglesii, Lindl., from the Swan River Settlement.

\section{EXTRACTS FROM PROFESSOR BURMEISTER'S MEMOIR ON THE PAUSSIDAE.}

(MAG. DE ZoOL, 18tl.)

After remarking upon the insufficiency of the charactcrs derived from the tarsi for the natural distribution of the Coleoptera into primary groups, and noticing that the structure of the wings has becn hitherto unemployed in characterizing the higher groups of beetles, Professor Burmeister considers that in the latter character he has discovered the true grounds for removing the Paussida from all the various families with which they lave been associated, and bringing them into the neighbourhood of the Carabidæ. Considering the great serviee which has been long obtained by employing the variation in the structure and position of the wing-veins in the Diptera and Hymenoptera, and which has rccently been extended to the Lepidoptera by Boisduval, Lefcbvre, and more especially Milne Edwards (from whom we may shortly expect a most elaborate memoir upon the subject), to the Orthoptera by De Haan, to the Homoptera by myself, and to a portion of the Neuroptera by Rambur; it is surprising that this character sliould have received so little attention amongst the Coleoptera; and, without assigning to it the primary importance attached to it by Burmeister, I eannot regard lis employment of it (ns well as of the number of segments of the abdomen, both in this memoir and in his Handbuch der Entomologie, vol. 4) otherwise than as proofs of a deep and philosophic spirit of inquiry.

"Je donne ici (observes Burmeister) quclques indications sur la eonstruction générale des ailes des Coléoptères. D'abord il est nécessaire de connâitre la construction de leur membrane, même

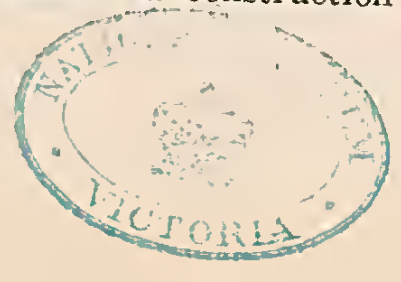


pour voir si elles sont couvertes de petits poils ou glabres. La petitesse des poils m'a fait longtemps croire que les ailes de tous les Coléoptères en sont privées, comme se sont veritablement les ailes des Lamellicornes; mais un examen plus attentif, avec un microscope composé, m'a montré que le plus grand nombre des Coléoptères, commo les Carabiques, les Hydrocanthares, les $\mathrm{Cy}-$ cliques, les Dimères, les Mycétoplaagiens, on la plupart des familles ont des ailes couvertes par des poils microscopiques. C'est aussi le cas des Pausida. Considérant, ensnite, la disposition des nervures dans les ailes, nous remarquons que tous les Coléoptères ont deux nervures principales, que je nomme nervure marginale et nervure radiale. La nervure marginale est située au bord antérieur de l'aile et est accompagnée généralement par une autre nerrure, plus petite, qui part aussi de la base de l'aile. La nervure marginale n'atteint pas le bout de l'aile; mais elle se termine, à peu près à la moitié, aux deux tiers ou aux trois quarts de sa longueur, pres du bord antérieur, par un articulation; c'est le point dans lequel l'aile est pliée, si elle doit être couverte par les elytres. La nervure radiale part de la base de la première, mais en divergeant sur un angle plus ou moins grand, cette nervure se dirige vers le bord posterieur de l'aile; mais elle ne l'atteint pas et se termine aussi par un sorte d'articulation à la même hauteur que celle de la nervure marginale. J'ai trouvée ces deux nervures dans toutes les ailes des Coléoptères, et souvent seules, comme chez les Cis, et dans la plupart des genres contenant des espèces très petites; mais, chez la plupart des Coléoptères, l'aile a des nervures accessoires. Ces nervures sont situées, tantot entre les deux nervures principales et tantot après la radiale. Je nomme les premières discoidales si elles sont entre la nervure marginale et la radiale, et apicales si elles sont apres les articulations des deux nervures au bout de l'aile: enfin, jc nomme basales toutes les nervures qui sont situées après la radiale, au côté du bord postérieur de l'aile. Ces trois groupes differents de nervures sont très variables chez les differentes familles des Coléoptères et donnent un très bon caractère pour les determiner." The wing of the Paussidx is then described in detail, and figures of the wings of Platyrhopalus denticornis, Calosoma sycoplianta, Dyticus marginalis, Gyrinus natator, $\mathrm{Cu}-$ cujus sp., and Bostrichus sp., are given by Dr. Burmeister, who adds,

"Un suel regard montre une ressemblance géuérale parfaite enti’e les ailes des Platyrhopalus, Calosoma, Dyticus, and Gyrinus; 
mais la plus grando différence entre los quatre ailes des earnassiers et eelles d'un Cucujus et d'un Bostrielius, genres aberrants de la famillo des Longicornes et des Rhyncophores. Nons arons ici, en même temps, l'uecasion de voir l'importance de' la configuration des ailes pour déterminer les familles naturelles; ear nous voyons les quatre ailes des Coléoptères, qui sont des membres d'un seul groupo naturel, tout-a-fait semblable: mais celles des autres groupes different, non senleument de celles des earnassiers, mais aussi entre elles; et la même ressemblanee que l'on voit dans les ailes de ees quatre earuassiers se trouvera si l'on eompare les ailes des Longieornes avec eelles du Cuenjus depressus, ou, d'un autre côte. si l'on eompare celles des Rhynchophores avec celles d'un Bostrichus. Je le répète, les ailes de tous les earnassiers sont convertes de petits poils microscopiques, et nous tronverons les mémes poils à l'aile d'un Platyrhopale."

Heneo he considers that-

" Les Pausides sont des Coléoptères carnassiers, très voisins des Carabiques et remplaent la même modification du type des carnassiers terrestres, comme los Gyriniens parmi les earnassiers aquatiques."

He then institutes an extended and very eareful series of comparisons between the structure of the various parts of the body of the Paussidse and various earnivorous genera, and thus procecds :

"L'analogic avec les Gyriniens n'est clle pas grande? ceux-ei n'ont-ils pas les mêmes jambes courtes ct comprimées comme la plupart des Pausides; et les tarses des Gyriniens ne sont-ils pas tout-à-fait particuliers et différents des tarses des Dytieiens? C'est pourquoi personne ne peut douter quo ces deux familles ne soient les membres d'un groupe plus grand et naturel que nous nommons des Hydrocanthares et qui est placé à côté des Carabiques, dans le plus grand groupe des carnassiers. Il cst necessaire de donner un nom général pour les denx groupes des Carabiques et Pausides, qui forment ainsi les Colćoptères carnassiers terrestr'es,

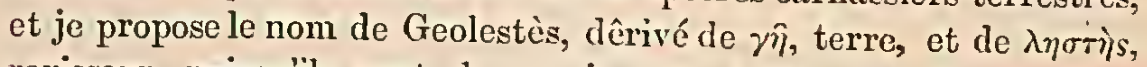
ravissenr, puisqu'ils sont des ravisseurs de la terre, eomme les Hydrocanthares les ravisseurs de l'eall. Ainsi les carnassiers sont déterminés et partagés de cette manière ;" the Geolestes composel of two groups, 1 Carabide, and 2 Pausside, and the HronocixTHaris of two groups; 3 Dyticida, and $\$$ Gyrinida. 


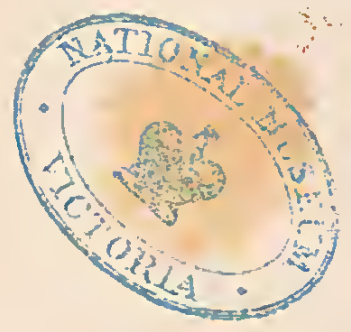


51.

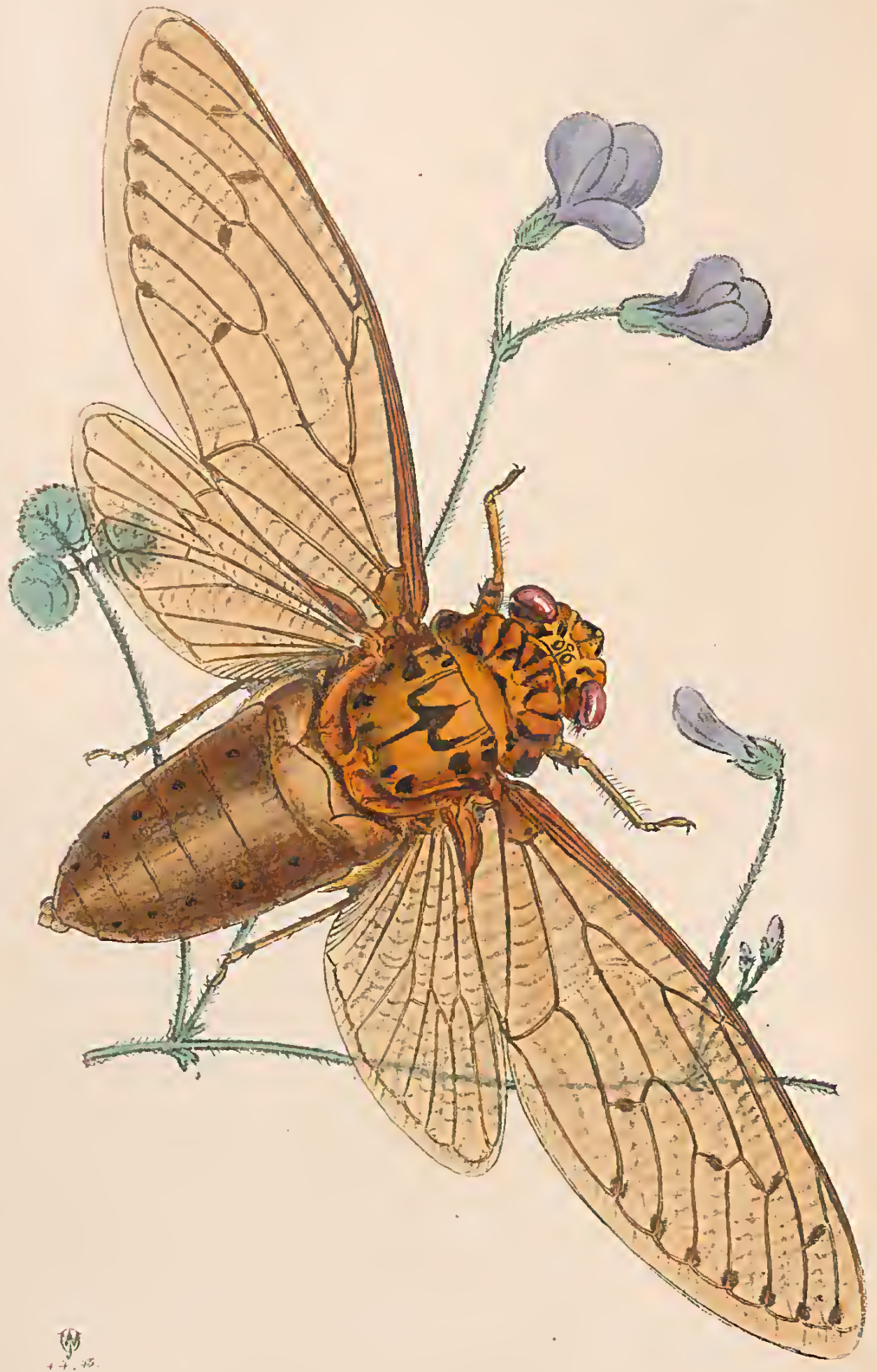


Dr. Gerarar, in his excellent memoir upon the species of the Genus Cicada, published in the Sth livraison of Silbermann's "Revue Entonologique," has arranged them in the following manner :-

1. Fore wings transparent and hyalinc.

A. Scutellum emarginate, sp. I-3.

B. Scutellum not emarginatc.

a. Head hroad and short, eyes prominent, sp. 4-38.

b. Head triangular, cyes simple, sp. 39-47.

2. Fore-wings coloured, coriaccous opake, sp. $48-53$.

3. Fore-wings coriaceous at base, with a transverse vein whicll divides them into two halves, sp. $53-60$.

It will be serviceable to compare Dr. Burmeister's arrangement, given in the second volume of his "Handbuch der Entomologie," with that of Dr. Germar. It is as follows :-

1. Fore-wings at the hasc parcliment-like, apical portion transparent lyaline.

a. Prothorax dilated at the sides. (C. stridula, \&c.)

h. Prothorax not dilated, narrower tlian the head. (C. philæmata, \&c.)

2. Fore-wings not horny at the hase.

A. Tarsi 3 -jointed.

1. Lateral margin of prothorax not dilated into a plate.

a. Head small. (C. formosa, villosa, rufescens, \&c.)

b. Head large; cyes prominent. (C. orni, \&c.)

2. Lateral margin of protherax dilated into a plate hroader than the hread head. (C olivacea Germar.)

B. Tarsi 2-jointed.

1. Prothorax with lateral dilatations. (C. tympanum, \&c.)

2. Prothorax not dilated at the sides, narrow. (C. mannifera, \&c.)

The species represented in the accompanying Plate (by far the largest of any hitherto known, and now for the first time figured), enters into Dr. Germar's section 1. B. b., and into that of 2. A. 1.a., in the arrangement of Dr. Burmeister. The following are its characters :- 
CICADA IMPERATORIA, Westuood. (Annals of N. H.)

Plate 51.

C. lutco-fulva, capite et thoracis dorso maculis plurimis magnitudine et forma variis, nigris; mesothoraceque figurn trifida notatis; pronoti lateribus in medio emarginatis et angulatis; abdomine brunneo lateribus pallidioribus maculn in singulo segmento utrinque nigra; alis flavido-livalinis, venis fulvis; anticarum venis transversis subapicalibus fusco nebulosis maculisque septem versus margincm fuscis. Long. corp. unc. $3 \frac{1}{2}$. Expans. alar. unc. $8 \frac{1}{4}$.

Inhabits the East Indies (Ncpaul, \&c.) and the Indian Islands. In my own and other collections,

This fine insect is nearly allied to C. fusca Olir. Stoll, Cigal, fig. 36, from the west coast of Sumatra, as well as to the Cicada flarida, of Guérin, figured in Belanger's "Voyage aux Indes Orientales." The specimen figured is a male, the drum-covers being visible at the sides of the base of the abdomen, hiding the greater part of the posterior femora on the underside. They extend no farther than is here represented. If this species make a noise proportioned to its size, it must indeed be loud. That of the small European species has long been famous, as the Odes of Anacreon prove. Having in the first volume of this work (p. 98) given an English translation of his Ode to the Cicada, a German one by Ramler, quoted by Burmeister, is here added.

Gilictlids nenn' id sid) Bifase!

Daj bu auf Sen biofften Batumen

Bon ein wenig Ihou Eegeiftert,

Uehntidy cinem Sinig fungeft.

Dein gehoret all uns jedes,

Thas ou in sen Felsern ithaueft,

$23 a s$ rie Sabreszeiten bringen;

Dir fino Freuns sie Eantbewohner,

25eil bu feinem lebft gu Eeibe,

Uno bie Eterbliduen wcrehren

Did, Des Enmmers holden Boten;

Lns es lieben sidb sie गuipen

llno es liebt sith Phoibos Telber;

Er gab sir bie flare Grinme; -

Tích sas Ilter sid nibt bránget,

Eeher, Erdgeborne, Eanger,

Ecisenlos, obn' Błut im Sleifone.

Sthier bift bu sen Bustern ábnlids !

The plant represented in the plate is the Indian Parochetus communis. 


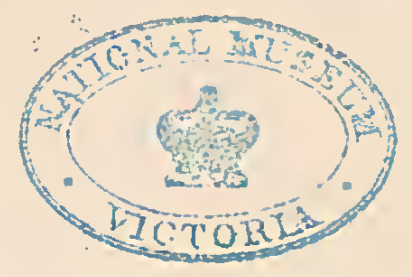




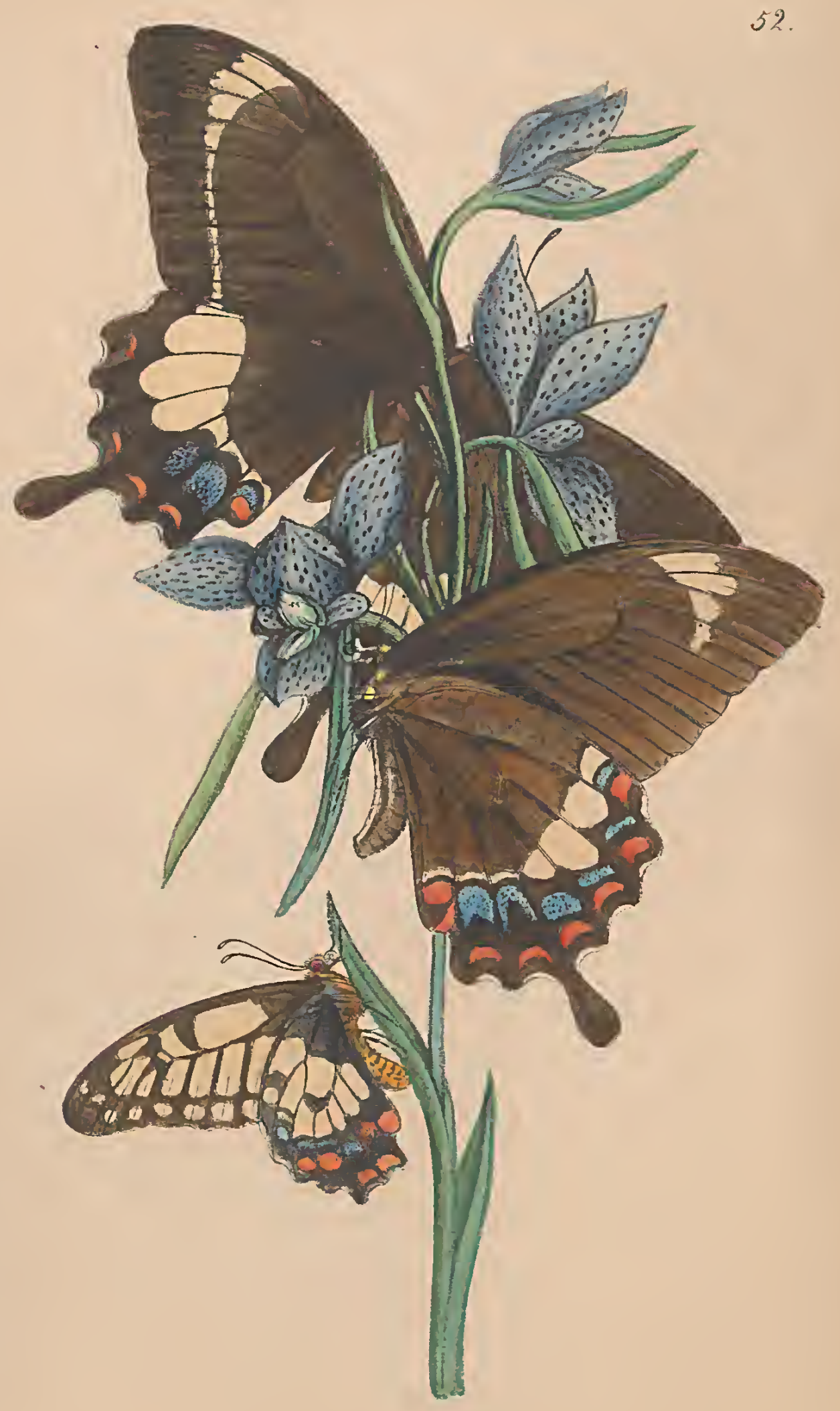


PLATE LII.

ON THE IUSTRALIAN SPECIES OF PAPILIO.

Tue spccies of Papilio hitherto recorded as natives of New Holland, are very few in number. The following is a list of all those which I am acquainted with as inhabitants of that portion of the world.

Species I.-Pap. Jlioneus, Donovan, Ius, N. H. (not of Abhot and Smith, Ins, of Creorgia.) Spectes II.-Papilio Canopus, Westw. in Ann. of Nat. Hist.; of which figures will be giveu in stubsequent number.

Sprcifs HI.-P'apilio Capaneus, Westw. (Plate 52, fig. sup.)

P. alis supla fuscis anticis striga tenui subapicali ad costam dilatata lutescenti, posticis caudatis macula magna straminea pone medium, in linea ad margincn analem ducta lunulis tribus rubris ocelloque rubro et cerulco at angulum analcm; anticis subtus fuscis, striga olsoleta, parte ad costam pallida solum relicta; posticis ponc medium scrio irregulari macularum albarum; Lumulisque sex fulvis spatio intermedio cxruleo irrorato ocelloque anali fulvo uigro ct cerulco, incisuris al bis. Expans. alar. unc. $4 \frac{3}{4}$.

Mus. Soc. Linn. ct Entomol. Loud. D. Alex. MIacLeay.

Species IV.-Pup. Frectheus, Donovan, Hübner, Exot, samm.

Pap. Egeus, Donovan, Hibucr (fim:le).

Specres Y.-Pap. MacLeayanus, Leach, Zool. Misc. Hübn. Zutr.

Species VI.-Pap. Sarpedon, Linn. Westw. Brit. Cycl. N. H. p1. for Butt.

I have received an Australian spccincu of this spccies from the Linnæan Socicty, being one of a collection sent by Mlex. MacLeay, Esq. It has not before bcen recorded as inhabiting a more southeru latitule than New Guiuca.

Spfcies VII.-Papilio Lycaon, Boisduval JISS.

A new species, very closely allicd to P. Eurypilus of Clerek's Icones and Evemon Bdv.; figures of which, already dram, will be giveu in a future number of this mork.

Species VIII.-Pap. Anlinous, Donovan, Ins. N. H.*

Specres IX.-Papilio Sthenelus, MacLeay. Scarcely distinguishable from P. Epius.

Sprcifs X.-Papilio Anactus, MacLeay, in Append. to King's Survey of Aust. p. 458.

Is no figure has hitherto appeared of this interesting specics, I have represented its under surface in the lower figuro of Plate 52. It has been described as allied to $P$. Epius and P. Machaon, but it las a much more striking relation to Papilio Cressida Fabricius. The upper side differs only in laving tho palc spots on the fore wings rather morc dusky than beneath. I was first acquainted with tbis species from a specimen in the collection of Mr. Lewis, of Kensington, the possessor of a fine collcction of shells. I have since obtaincd the spccies from in dealer in insects.

Spectes XI.-Papilio (Eurycus) Cressida, Fabr. Donovan. Cressida Heliconides, Swainson, Z. I. 2 d scr. pl. 94.

Specres XII.-Papilio (Eurycus) Harmonia, Fabr. Donovan.

The orclidaceous plant represented is the Australian Diuris punctata, Smith.

* A butterfly, which appears to me to differ in no respects from Donovan's figure, stands in tbe collection of the Jardin des Plantes, with tbe manuscript name of Papilio Alcxander attached to it. 


\section{TO A BUTTERFLY.} FROM HERDER.

LIGHx and lovely thing of sky, Butterfly!

Flutt'ring ever amid flowers, Fed on buds and dewy showers, (Flower thyself, or leaf with wings!)

Say, what finger rosy-red Thy rich colours brings?

Was 't some sylph that o'er thee threw Each bright hue?

Raised thee from morn's fragrant mist,Bade thee through thy day exist?

Al, beneath my fingers prest, Palpitates thy tiny heart, E'en to death distrest.

Fly away, poor soul! and be Gay and free!

Thus, no more a worm of earth, I shall one day flutter forth; And, like thee, a thing of air, Clothed in sweets and honeyed dews, Each sweet flow'ret share! 
$(9$ 


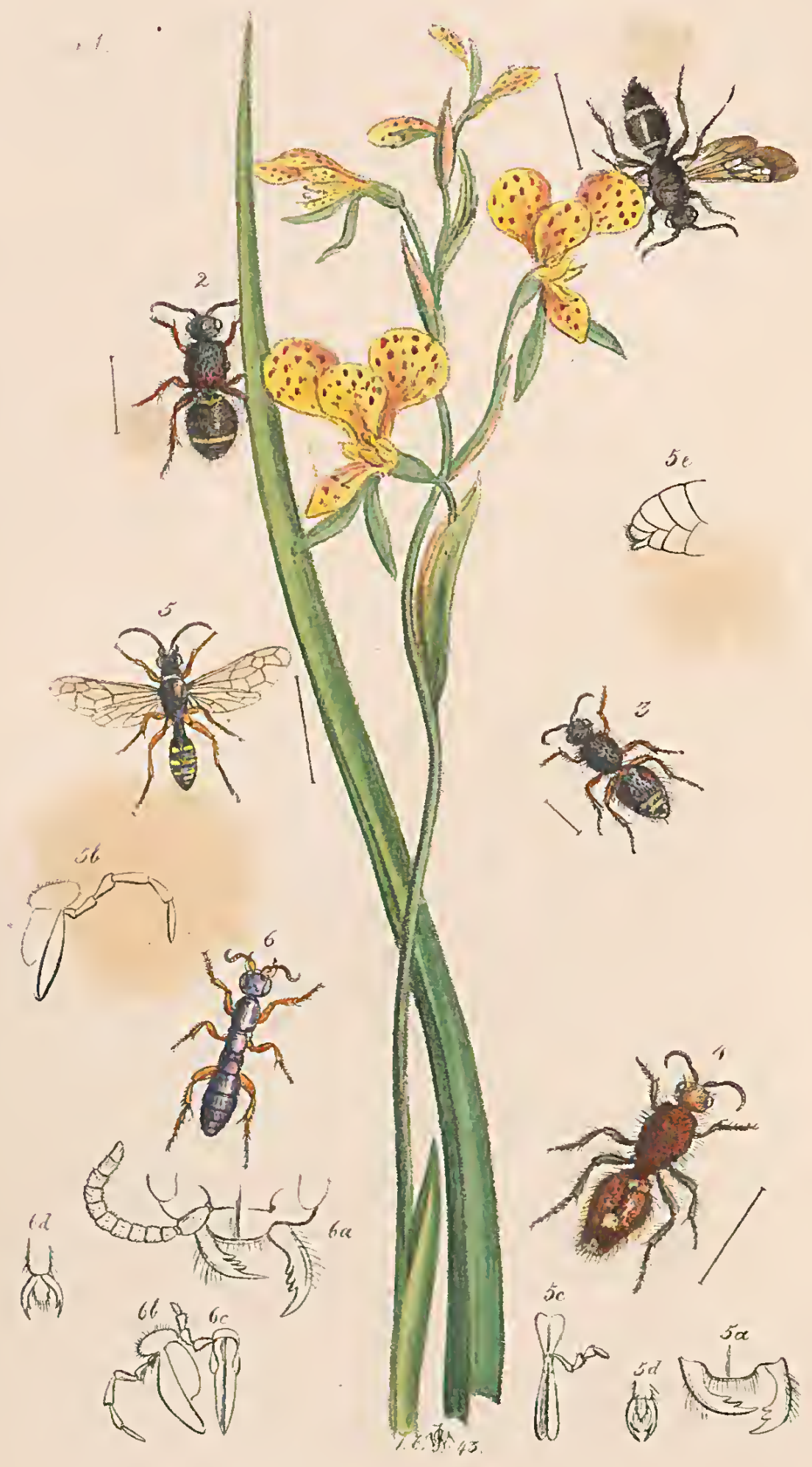




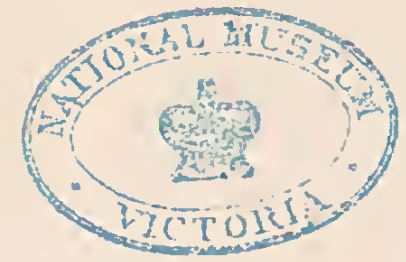




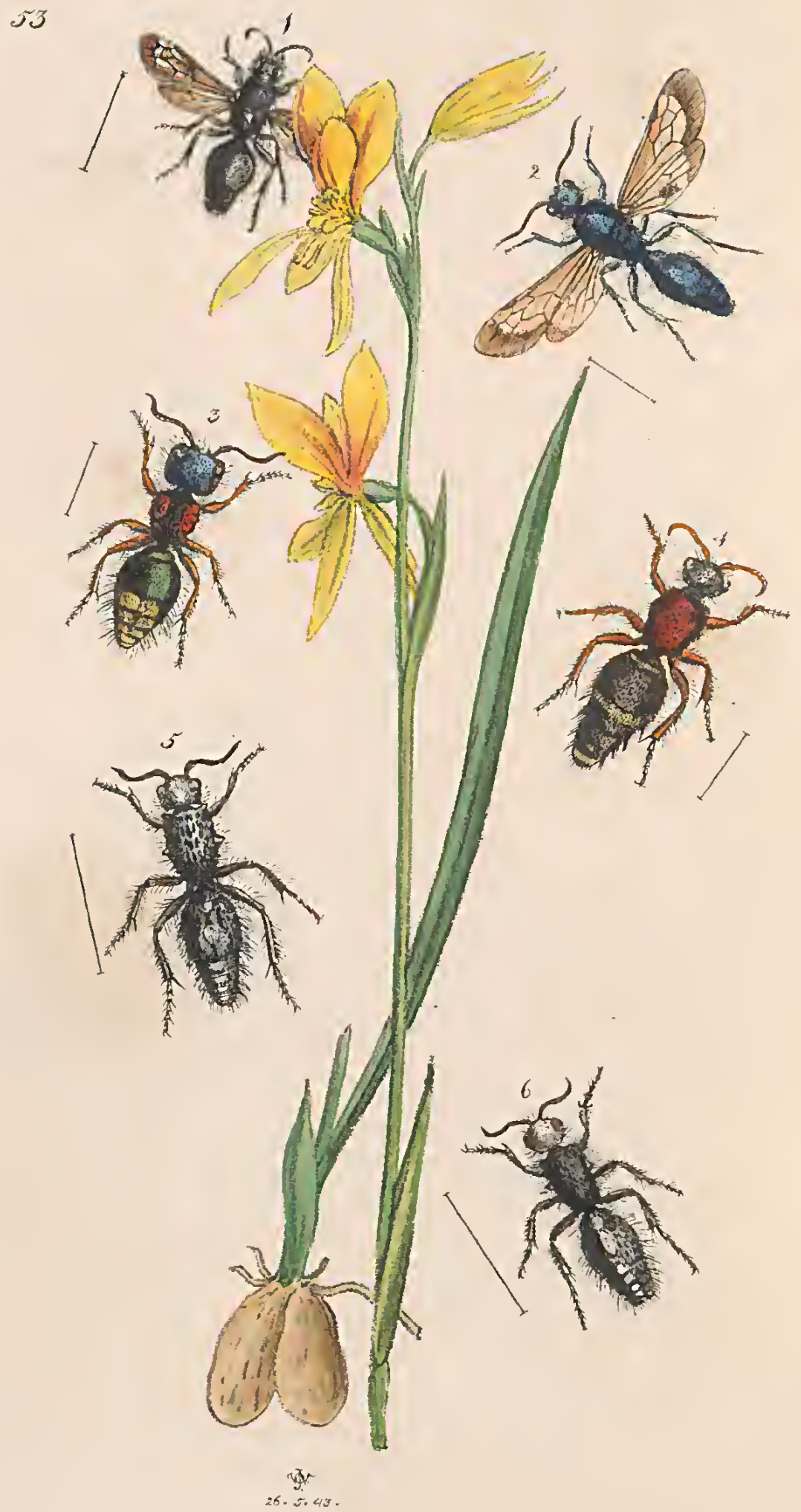




\section{PLATES LIII. AND LIV. \\ ON THE MUTILLA OF NEW HOLLAND.}

IT is a curious circumstance, in reference to the geographical distribution of insects, that the two Hymenopterous groups of fossorial species, possessing apterous females, should be so unequally dispcrsed over the surface of the earth. Whilst the genus Mutilla is found in every quarter of the globe, Thynnus is confined to the southern hemisphere, and is here only met with in the Australian and South American continents. It is further worthy of notice, that whilst Thynnus is a numerous group in Australia and rare in South America, the Mutille of the western world are far more numerous than those of New Holland and its dependencies.

It is most probable that the economy of both these groups are identical, and that the females are sand-burrowers; and the males attached to flowers rather than predaccous in their liabits.*

$$
\text { Genus.-MUTILLA, Linneus. }
$$

The following are all the Australian species of Mutilla which I have hitherto seen in collections, or of which I have met with the descriptions :-

Species I.-M Mutilla formicaria. (Plate 53, fig. 6.) M. nigra, capite cinerascenti-lirto, thorace nigro, scabro, lateribus vix tuberculatis, abdomine nigro (subpiceo in certo situ), linca dorsali macularnm albo-cinerascentium lateribusque abdominis albo-birtis. + . Long. corp. lin. 9.

Syn.-M Mutilla formicaria Fabricius, Ent. Syst. 2, 368. Syst. Piez. p. 430.

Originally described by Fabricius from the Banksian Cabinet, where the specimen still remains. The Rev. F. W. Hope has reccntly obtained a specimen in Mr. Gould's collections from Port Essington.

Specres II.-Mutilla rugicollis Westw. (Platc 53, fig. 5.) M. nigra nitida scabra, capite, mnculis dorsalibns pilisque lateralibus abdominis albo-cincrascentibus, thoracis angulis anticis lateribugque tuberculato-angulatis, thoracis dorso punctis magnis oblongis, netathoraceque spatio clongato-tiangulari impresso, abdominis segmento secundo magno valde scabro, medio tenue punctato, plagaque rotundata albo-cinerascenti alteraquo scmicirculari basali o pilis segmenti basalis formata, segmentis, reliquis etian plaga ejusdem coloris notatis. 우 Long. curp. lin. $9 \frac{\overline{3}}{2}$.

In the cabinet of the Britislı Museum, ticketed "Hunter, New

* A memoir on the habits of some Indian species of Nutilla, by Captain Boys, was resd at the Entomological Society, on the 5 th $\mathbf{J u u c}, 1843$, in which are described tho procecdings of a male in the act of dragging along a dead cockroneh, in a manner prcciscly similar to that adopted by female fossorial insects, whilst provisioning their nests. It is scarcely to be supposed that a male Mutilla could have been thus employed.

No. XIV.-Ist JULY, 1843. 
Holland," and in the collection of the Rev. F. W. Hope, from Western Australia.

Ozs.-This species is very closely allied to MI. formiearia, but is at onee distinguished by the strueture of the thorax and seulpturo of the body.

Speres Il1.-MLutilla ferruginata, Westw. (Plato 54, fig. 4.) M. ferruginea punctata, eapite cinerascenti-hirto, abdomine maenlis tribus e pilis fulvis in medio marginis postiei segmentorum $1 \mathrm{mi}, 2 \mathrm{di}$ ot nltimi ; antennis pedibueque nigris, tarsis piceis, thorace ovali anticè truneato, dorso punetis regnlaribus rotundatis; lateribus haud tubereulatis ; segmento 2do abdominis magno in inedio longitudinaliter impresso; dorso punctis oblongis impresso. ㅇ․ Long. colp. lin. 7 .

In the collection of Joln Curtis, Esq., F.L.S., \&c., from New Holland.

Spreies 1V.-Mrutilla aurata. M. ecruleseens lirta, antennis fuseis, abdominis segmento primo maximo maeula magna dorsali aurata nitente; reliquis segmentis basi atris; alis nullis. 오.

Srn.-M. aurata Fabrieius, Ent. Syst. 2, 368. Syst. Piez. p. 430.

Described as a native of New Holland, by Fabricius, from the Banksian Collection. I have not, however, been able to discover the species in the cabinets of the Linnæan Society.

Spec1es V.-MIutilla ruficornis. MI. nigra, antennis rufis, ano pilis albidis tecto, alis atris. ô. Svn.-MI. ruficornis Fabrieius, Ent. Syst. 2, 369. Syst. Piez. p. 431.

Also described by Fabricius as a native of Now Holland, from the same collection as the last, but I have not been able to find it there.

Speces V1.-Mrutilla Australasice. M. lirta nigra antennis rufis tloraceque hirto obseure rufo, abdomino orato nigro segmentis 1,2 , ultimoque margine ciliato aibis, pedibus rufis. II. ciliato triplo Iuajor.

Srn.-1M. Australasice Fabrieins. Syst. Piez. p. 433.

Described by Fabricius as a native of "Nova Cambria," from the collection of Labillardière.

Speeres V11.-M Mutitla dorsigera, Westw. (Plate 53, fig. 4.) M. nigra, parum hirta obseura, tenue at valdo punctata, antennis pedibus, mandibulis basi dorsoque collaris et thoracis obscure rufis, abdomine opaeo, nigro, segmentis 1,2 et ultimo striga marginali c pilis albo-seriecis formata, einetis; thoraee in medio lateribus parum angulatis capiteque, parum latiore, abdomineque multo minori; pedibus antenuisque brevioribns. 우. Long. corp. lin. $4 \frac{1}{2}$.

Habitat in Terra Tan Diemenii. D. Lewis. In Mus. Westw.

I can scarcely think this to be identical with the M. Australasice, although it is closely allied to that species.

Sprcies VIII.-MIutilla affinis, Westw. (Plate 54, fig. 2.) M. brevis robusta nigra hirta punctata, thorace postieo obseure ferrugineo, abdomine segmentis 1 et 2 pilisque analibus albidis, pedibus pieeo rufis, antennis tareisque obseuris, thorace supra tenne oblongo-punetatis, abdomino brere-ovali tenuissime punetato. $\$$. Long. corp. lin. $4 \frac{1}{2}$. IIabitat in Nova Hollandia. In Mus. Brit. No. 550 .

Allied to M. dorsigera, but much more robust in proportion to its size, and more obscurely coloured.

Spectes IX.-MUtilla lateralis. Westw. (Plate 54, fig. 3.) M. nigra subopaca punetata, antennis mandibulisque nigris, pedibus rufis, ablominis segmento basali supra, 2di late. 
ribus et subtus ferrugineis; loe ct reliquis al marginem posticum pilis aureis ; facio ante oenlos plama et recte truncata. 웅. Long. corp. lin. $2 \frac{1}{5}$.

Ifabitat in Terra Van Diemenii. In Mus. D. W. W. Saunders, F. L. S.

Speces X.-Mutilla elegans, Westv. (Plate 53, fig. 2.) M. tota cxrulea nitida punetata, cinerascenti-hirta, antennis longis tarsisque nigris, abdomine elongato, segmento $1 \mathrm{mo}$ pctiolari, alis pallido ciuerascenti-hyalinis apice late fuscis. $\delta$. Long. corp. lin. $4 \frac{1}{p_{0}}$. Expans, alar. lin. $6 \frac{3}{4}$.

Habitat in Terra Van Diemenii. D. Ewing. Mrus. Brit et Westw.

In this species the veins separating the submarginal cells are inserted into the marginal cell at nearly equal distances apart; and tho first recurrent vein is received by the second submarginal cell rather beyond the middle, whilst the second recurrent vein is received nearly at the extremity of the third submarginal cell, forming nearly a straight line with the extremity of the third submarginal cell.

SPECIEs X1.-Mrutilla abdominalis, Westw. (Plate 53, fig. 1.) M. nigra tenuiter punctata hirta, capite scutelloque cinerascenti hirtis, abdomine obseure purpureo tenuissime punetato pilis albis utrinque ad apieen segmentorum 2 di et ultini ; pedibns nigris, tibiarum 4 posticarum ct artieulo basali tarsorum albis ; alis fuseis, byalino-variegatis, segmento basali abdominis parvo nodum parrum transversum ad basin formanti, 210 magno eam. panulato. A. Long, corp. lin. 6. Expans, alar. lin. 11.

Habitat in Australasin. In Mus. Brit.

The insertion of the veins in this species is very similar to that of the preceding species.

Species XIT.-Mutilla morosa, Westr. (Plate 51 , fig. 1.) Mt. nigra punetata nigrohirta, thoraeo rugosc-punetato, abdomine faseia pilorum alborum ad apicem segmentorum $1 \mathrm{mi}$ et $2 \mathrm{di}$, loc parum constricto, alis hyalino et fuseo variis, apice late fusco. Long. enpp. lin. 6. Expans, alar. lin. $9 x$.

Habitat "Swan River." In Mus. Brit.

SPEcies XIII.-Mutilla concinna, Westir. (Plate 33, fig. 3.) Mr. capite magno, cyaneo punetato antice bicornienlato, thorace parvo nigro oblongo-punctato, lateribos et subtus ferrugineis, abdomine magno aneo nitido, sericeo, posticc pilis aureis in maeulas dispositis ornato, antennarum articulo basalf mandibulisque (nisi ad apices oblique emarginatos) pedibusque ferrugineis. Long. corp. lin. $4 \frac{1}{2}$.

Habitat in Terra Yan Diemenii. Mus. Netrman, Westwood, etc. The trophi do not differ in this curious species from those of the rest of the genus.

$$
\text { GENus.-PSAMATHA, Shtzckard. }
$$

This genus was established by Mr. Shuckard, in the Transactions of the Entomological Society of London, for tho reception of an insect having precisely the labit of a male Mellinus, but remarkable as being the only one yet characterized among the Mutillide in which the second sub-marginal cell receives both the recurrent nervures, ${ }^{*}$ in which respect it also differs from all the species of insects of which Thynnus is the typical form, except tho genus Tachypterus Guérin. Dr. Klug having on this account omitted the genus and its supposed female in his beautiful memoir on the Thynni, recently published in the Berlin Transactions, I have been 
inducer to add a figure of it, and of Diamma cærulæa, to my representations of Australian Mutille.

As the genus Psamatha lias been described at some length in the work above referred to, it will be necessary only that I should notice some peculiarities omitted by Mr. Shuckard; these relate especially to the structure of the mouth. The clypeus (plate 54, fig. $5 a$ ) is carinated down the middle, being produced in a transverse lobe over the labrum, of which the anterior ciliated margin is almost hidden. The mandibles are much curved, and terminate in three acute tecth, the apical one bcing the largest. In the male Mutille the mandibles are simply bifid; tho same is also the casc with the majority of tho Thymi. The Chilian Telephoromyia Gnér: and tho Kangaroo Island Tachypterus Gućr. have, lowever, the mandibles bidentate witlin. The maxillæ (fig. 5 b) in Psamatha do not materially differ from the general form of these organs amongst the fossorial species, with 6-jointed maxillary palpi ; the labium (fig. $5 \mathrm{c}$ ) in my specimen is considerably exserted and emarginate at the tip, arising from a very narrow carinated mentum, slender in front, and witl 4-jointed labial palpi. The ungues in all the feet are bifid, (fig. 5 d), in which respect the insect agrees with the Thynni, and differs from the Mutillæ. The eyes are but very slightly cmarginate on the inside, whereas they lave a deep notch in the male Mntilla. The veins of the wings extend quite to the apical margin as in the Thynni, whereas in the Mutilla they stop at some distance from the margin. And lastly, tho want of colour in these organs, as in this insect, occurs in the Thynni more ordinarily than in tho Mutillæ. The oxtrcmity of the abdomen (fig. $5 e$ ) is incorrectly described by Mr. Shuckard, as it has only one valve on each side projecting beyond it (in $\mathrm{my}$ specimen bcing coloured whitish) forming the quadrant of a circle, and externally fringed; the apical ventral plate is truncate at its extremity, and not produced into a spine as in many Thynni, nor bidentate as in the male Mutillæ.

Species 1.-Psamalha chalybea, Shuckard. (Plate 64, fig. 5.) Chalybca nitida griscopubcscens, margine postico prothoracis albido, abdomine atro utrinque maculis quatuor

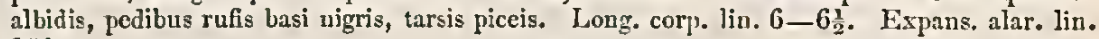
$11 \frac{1}{2}$.

Habitat in Terra Van Diemenii. Mus. Soc. Ent. Lond. Saunders, Shuckard, ct Westrr.

I am indebted to W. W. Saunders, Esq., for this interesting species.

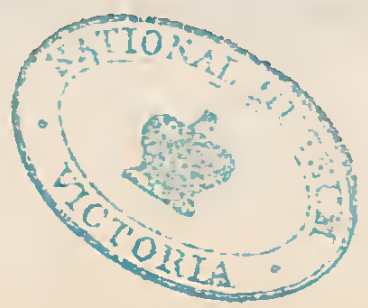


DIAMMA, Westw. (In Procecdings of Zool. Soc., April 14, 1835.)

Corpus elongatum nitidum apterum, thorace in medio constrictum scgmentisque abdominis basi subcoarctatis. Caput subhorizontale fere rotundatum. Clypeus (fig.6 a) nocdio longitudinaliter carinatus, antice in lobum transversum, super labrum productus. Labrum mangine antico cilinto. Mandilula Jongas currate falents, intus ct ante apicem acutum deutibus tribus sequalibus armate. Maxillm (fis. 6 b) lobo cxtcrno tenui margine rotundato ; palpi naxillares graciles 6 -articnlati articnlis $3 \mathrm{ct}+$ longioribus. Mentum corneum (fig. 6 c) clongatum labio in apico ejus retratilic. Palpi labiales 4-articulati articulis iutermcdins obconicis. Antcuna breves convoluta 12, articulates articulo 2ndo minuto, apicalibus gracilionibus. Thoras quast binodosus. Nolus anticus fere rotundatus $\mathrm{c}$ collari maximo constans. AIcsonotum in annulum brevcm tagustum contractum. Mesostcrnum unajus, obliquum, et pedes intermedios gerens. Metathorax inagnus nodum posticum thoracis constituens et spiraculis duobus lateralibus instructus. Abdomen oblongo-ovalo subdcpressum scgmcuto basali ad apicem constrictum. Pedes breviusculi spinosi unguibus bifidis (fig. 6 d).

THE very interesting insect, which is the type of this genus, is closely allied to Myrmecodes Latr., or the females of Thynni and to Myrmosa Latr. The peculiar toothing of the mandibles, is, however, quite unlike that of those insects, whilst the elongated maxillary palpi are still more unlike those of the female Thynni, T. variabilis o for example, in which the maxillary palpi are extremely short and apparently only 3-jointed, a peculiarity overlooked by Dr. Klug in his Memoir on Thynnus, althongh it is one which would have caused him to hesitate previous to sinking all the genera established by M. Guérin. I am unwillingly prevented at present from entering into this part of the subject so fully as it deserves, and shall only add that, in the females of Myrmosa, Methoca, and Mutilla, the palpi do not differ from those of the males, which is also most probably the case in Diamma. The very slight pilosity of the body of the type of this genus, its polished surface, articulated thorax, and bifid ungues, are all characters which it, however, possesses in common with the female Thynni; which appcar to me to be its nearest allies.

SpFcies I.-Diamma bicolor, Westw. (Plate 54, fig. 6.) D. tota purpurea, cyaneo, vel xneo nitens, antennis pedibus mandibulisque rufis, his ad apicem nigris. Long. corp. lin. $9 \frac{1}{2}$

Habitat in Terra Van Diementi. In Mus. nostr., \&c. Communic. Dr. Ewing, \&c.

M. Guérin has described a female insect from Kangaroo Island (in the Voyage de la Coquille, texte, p. 235,) under the name of "Diamma ephippiger; A pterus, niger nitidus laevigatus mesothorace, metathorace pedibusque fulvis." Like D. bicolor 9 , it has 6 -jointed maxillary palpi, but the mandibles have only in single tooth within, and Mr. Shuckard assures me that this insect is the female of Rhagigaster unicolor, an insect which differs considerably from Psamathic. 
The plant represented in pl. 53 is the Australian Diuris aurea of Smith, and that in plate 54 is D. maculata, from the samo country.

"This is human happiness!

Its secret and its evidenee are writ

In the broad book of Nature. 'Tis to have

Attentive and believing faculties;

To go abroal rejoicing in the joy

Of beautiful and well-created things;

To love the voice of waters, and the sheen

Of silver fountains leaping to the sea;

To thrill with the ricl melody of birds,

Living their life of music; to be glad

In the gay sunshine, reverent in the storm;

'To see a beauty in the stirring leaf,

Aud find calm thoughts beneath the whispering tree;

To see, and hear, and breathe the evidence

Of God's decp wislown in the natural world!

It is to linger on "the magic face

Of hurnan beauty,' and from light and shade

Alike to draw a lesson; 'tis to love

The cadences of roices that are tuned

By majesty and pnrity of thought;

To gaze on woman's beauty, as a star

Whose purity and distance make it fair;

And in the gush of music to be still,

And fcel that it has purified the heart!

It is to love all virtue for itself,-

All nature for its breathing evidence;

And when the eye liath seen, and when the ear

Hath drank the beautiful harmony of the world,

It is to humble the imperfeet mind,

And lean the broken spirit upon God!" 


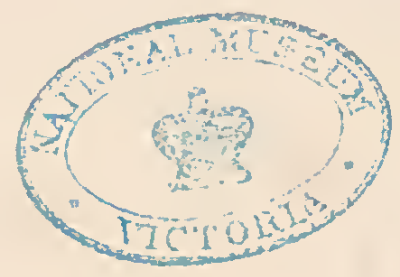




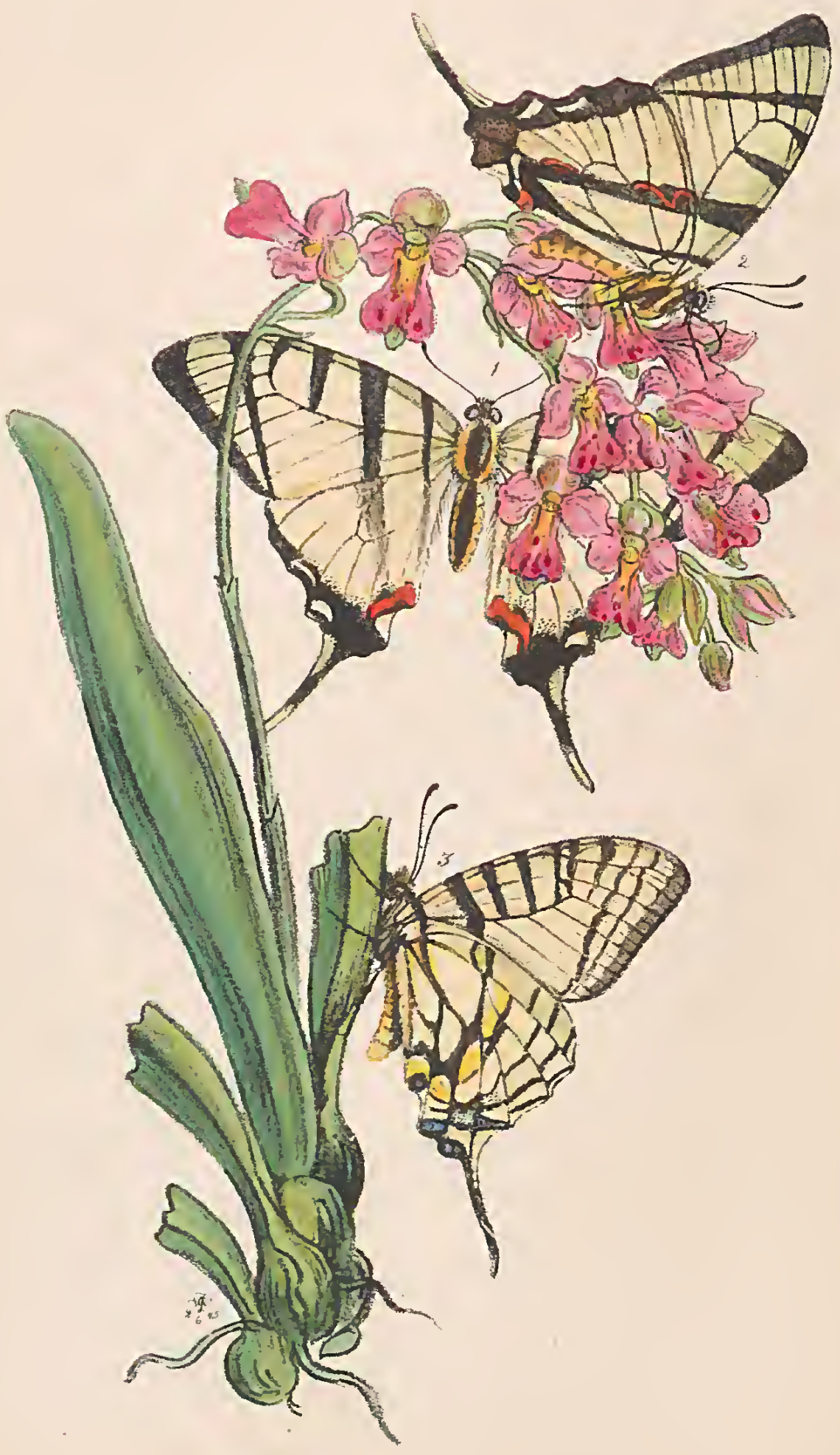


PLATE LV.

ILLUSTRATIONS OF TWO HITHERTO UNFIGURED SPECIES OF THE GEXUS PAPILIO FROM INDIA.

Those beautiful species of the genus Papilio, which are for the most part distingnished by having the ground of the wings pale yellowish or cream-coloured, traversed by straight black fascia, often extending across both tho wings, and having the hind wings tcrminated by long slender tails, and which constituto Boisduval's sixteentl group, appcar to be dispersed nearly over the wholo globe, and hence from this cosmopolitan disposition, and the great similarity which exists amongst the species, some confusion both in the synonymes and habitats of scveral of them lias taken place. Thus the Papilio Nomius of Esper, (P. Meges Hb. P. Niamus, Godart. Swainson, Zool. Ill., 2 ser., pl. 32,) an inscot now known to be a native of India*, was described by Godart as an inhabitant of Brazil, whilst Mr. Swainson evon asserts that he took the species in that country. Other allied species appcar to be of the greatest rarity in tho East, amongst which may especially be mentioned P. Telamon, of Donovan, a nativo of China, which wo may now, perhaps, hope to reccive; P.Dor'cus Reinwardl, beautifully figured by M. De Haan in the 6th plato of his splendid Memoir on the Papiliones of tho East, and the two species represented in my plate ; of these the two upper figures exhibit both surfaces of tho wings of an entirely new spccies, whilst tlie under figure represents the underside of a species not hitherto figured, and of which a description of the upper side alone has hitherto been given to the public.

\section{PAPIllo aGeTES, TVesiw. (Plate 55, figs. I, 2.)}

P. alis pallidissime stramincis costa vix virescenti, anticis fisciis 4 (tertia a basi abbreviata, margineque apieali nigris, posticis margine apieali nigro maculaque anali rubra. Expans. alar. une. $3 \frac{1}{4}$.

Inhabits the East Indies (Syllet?) Mus. Brit.

This elegant species is allied to P. Agesilaus, and especially to $P$. Dorcus. The extremity of the discoidal cell in the fore wings is connected with the costa by a small black conical mark, which in some of the allied species becomes an additional fascia. The two basal bars of the fore wings are earried across the lind ones beneath;

* I have now before me a considerable number brought homo by Colonel Hearsey, a gentle. man devotedly attaelied to the study of the transformations of Indian Lepidoptera. 
the seeond being marked near the eostal margin of the latter with two red curves, whieh, as well as the bases themselves, are slightly visible through the wing, when seen from above; the dark margin of the hind wings bears two white lunules, and these wings lrave a white marginal spot below the anal angle, which is marked with a long red patch, surmounted above by black, and resting on an oblique short black streak.

\section{PAPIlio GLYCERION, Gray. (Plate 55, fig. 3.)}

This species was first very eoneisely deseribed by Mr. G. R. Gray, in the Zoologieal Misecllany*. Boisduval subsequently gave a more detailed deseription of its upper side from a drawing sent him by the former author. I have therefore preferred figuring the under side. The upper surface of the fore wings differs from the under in having the blaek bars at the extremity of the wing more distinct and broader, and the under wings are much less varied with the dark marks, which are eonfined nearly to the apieal margin. The space between the base of the tail and the anal angle is eorered by a pateh of black; the yellow spot is, however, not surmounted by the black line.

I am indebted to Captain Parry for an opportunity of figuring this rare species, whieh he reeeived from Semlah, in the East Indies.

The Nepalese plant represented in the plate is the Orehidaeeous Tribraèlia reptans. Lindl. Coll. Bot., tab. 41.

* The Platcs and descriptions of Gencral Hardwicke's insects, quoted by Boisduval, have not been published. 
(1) 
56

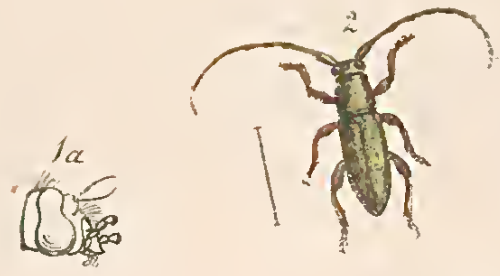

0
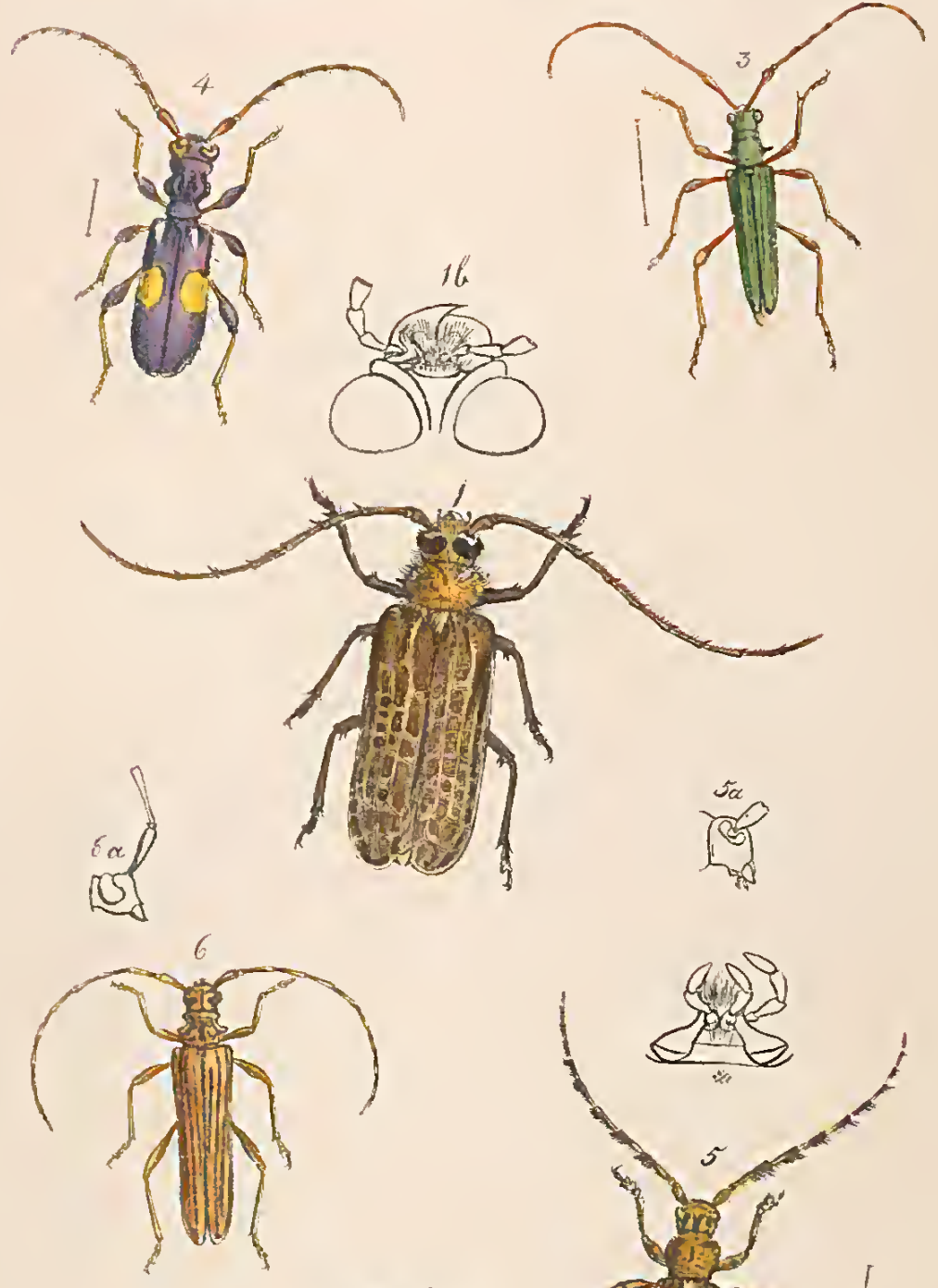

thention

10.4

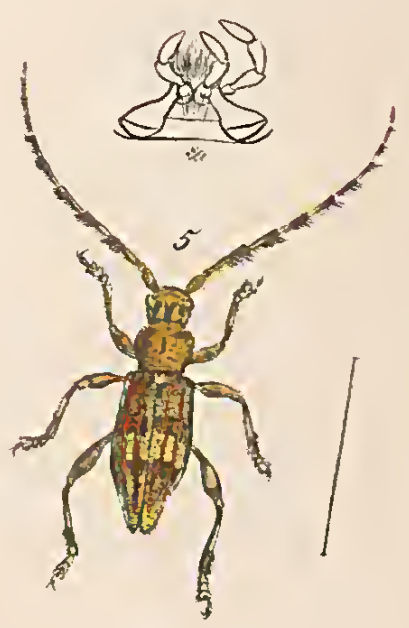




\section{PLATE LVI.}

ON THE LONGICORN COLEOPTERA OF NEW ZEALAND.

Captain F. Parry having placed in my hands for publication some of the Longicorn species of beetles which he has recently obtained from New Zealand, I liave considered that it would be serviceable to add to my descriptions a list of all the Longicorn species, hitherto described as natives of that country, which is accordingly given beneath, being chiefly derived from the Appendix to Dieffenbach's Travels.

Specres I. - Prionus (Prionoplus) reticularis, White, in Dieff. Trav. vol. ii. App. p. 276. (Plate 56, fig. 1). P. piceo-fuscus; facie, pronoto, et thorace subtus pilis aureo-fuscis tomentosis, elytris pallide reticulatis.

Long. corp. lin. $17-18$.

"This Prionus forms a section or sub-genus distinct from Sceleocantha and Toxeutes of Newnan (Annals and Mag. of Nat. Hist. v.pp. 14, 15), the latter founded on the Australian Prionus arcuatus, Fabr.; it differs essentially from Malloderes, Dupont (Guér. Mag. Zool. 1835, pl. 125), and Aulacopus, Serville (Ann. Soc. Ent. France, 1832, pp. 144, 145), of the characters of the species of which it partly partakes,"-White, op. cit. Malloderes, founded upon a Chilian insect, and Trichoderes of Cherrolat (Guér. Mag. Zool. 1843, pl. 113), upon a Mexican species, differ from the present in the armature of the thorax, each side of which, in our insect, is armed with a short spine in the centre. The eyes are of a very large size, the palpi short, the third and following joints of the antenna terminated by a short spine. The male antennæe are rather longer than the body. All the femora are armed within at the tip by two short spines, and the elytra are rounded at the tips, with a short spine at the extremity of the suture.

Captain Parry's specimen is from Port Nicholson. Fig. 1 a, represents the head seen laterally, and fig. $1 \mathrm{~b}$, the underside of the head.

Species II.-Phoracantha dorsalis.

Sxw.-Stenochorus dorsalis, Macleay, in Append. to King's Survey, ii, p. 45 I.

Phoracantha dorsalis, Newman, Ann. of Nat. Hist. ४. p. I9; White, op. cit. p. 278.

Species III.-Coptomma variegatum, Whitc, op. cit. p. 278.

Syn.-Callidium variegatum, Fabricius, Ent. Syst. 2, 325 ; Syst. El. 2, 340 ; Oliv. 70, tab. 5, fig. 58 .

Tmesisternus var., Bdv., Guérin.

Coptomma vitticolle, Newm. Ann. Nat. Hist., v. p. 18. 
Described by Fabricius from the Banksian Collection, which still possesses the typical specinen. Also in the British Museum Collection, presented by Drs. Dieffenbach and Sinclair.

Species IT.-Coptomma sulcatum, White, op. cit. p. 278.

Srv.-Callidium sulcatum, Fabr. Syst. Ent., p. 189 ; Syst. Elcuth. 2, 340 ; Oliv. Eat. 70 , t. 4 , fig. 48.

Tmesisternus sp., Latr.; Guér.; Voy. Coq. texte, p. 130.

Described by Fabricius from the specimen still remaining in the Banksian Collection.

Species Y.-Coplomma linealum, White, op. cit. p. 279.

Syn.-Callidium linealum, Fabr., Syst. Ent., p. 189 ; Oliv. Ins. 70, t. 4, fig. 50.

Tmesisternus sp., Latr. ; Guér.; Toy. Coq. texte, p. 130.

Coptomma fusiforme, Newman, MS. in Brit. MIus.

Also described by Fabricius from the specinen still existing in the Banksian Cabinet. It is also in the Cabinet of the British Museum, although not so indicated by Mr. White.

Spec1es VI._Lamia crista, Fabr., Syst. Ent., p. 176; Ent. Syst. 2, 268 ; Syst. Eleuth. 21, p. 282 ; Oliv. Ins. 67 , tab. 14, fig. 101 ; Whitc, op. cit.

Described by Fabricius from the Banksian Cabinet.

Species VII.-Lamia pulverulenta, Westw., (Plato 56, fig. 5).

L. nigra olscura, albida pulverosa, thoracis lateribus inermibus, clytris nigro-bifasciatis fulvoque costatis, antcnnis pedibusquo albido fasciatis, illis externe setosis.

Long. corp. liu. 9.

Inlabits Port Nicholson, New Zealand. MIus. Parry.

This curious species differs from all the other Lamix, and somewhat approaches 'Tmesisternus in the form of the head. I am not, however, sufficiently acquainted with the distribntion of the Longicorn beetles to warrant my proposing a new genus for its reception. The head (fig. 5 a) is rather elongated behind the eyes, with the front part nearly perpendicular; it has two whitish lines behind; the palpi are short (fig. ${ }^{*}$ ) with the extremity rather pointed; the antennæe are 11-jointed, the third joint being the longest, and all the joints being fringed on the outside witl liairs, alternately coloured as the joints themselves, the bases of which are white and the extremities black. The thorax is nearly rounded, with the sides unarmed; the elytra are convex, the humeral angles prominent, and the hind part much attenuated and deflexed; the tips not spined but pilose; along each run four slender, fulrous, elevated costr, which do not extend to the tip; the middlc of the elytra are ornamented with two interrupted black fasciæ; the legs are varied with black and whitish colonrs, the extremity of the tibia bcing externally setose. 
Speces VIII.-Cerambyx strigipennis, Westw. (Plate 56, fig. 6).

C. sordide luteus, picco longitudinaliter striatus, thoracis dorso et lateribus tubcrculatis, antennis nigro amnulatis, pedibus gracilibus pallidis.

Long. corp. lin. 11.

Habitat Port Nicholson, New Zealand. MLus. Parry.

The head is broad in front before the eyes, and with the face rather oblique (fig. $6 \mathrm{a}$ ), and truncate, and the parts of the mouth are small; the mandibles short (fig. $6 \mathrm{~b}$ ), and black at the tip ; the palpi also short, the maxillary ones scarcely longer than the labial (fig. $6 \mathrm{c}$ ); the antenna are shorter than the body, with the first joint clavate, the third and several following of nearly equal length, with the base of the joints black; the head has a dark central line, and the space behind the eyes is also dark-coloured; the thorax is constricted near the front margin, and dilated on each side into a short, thick, conical spine; the disk has also four elevated tubercles, placed thus,.$\because$; the middle of the thorax is marked with a dark line. The elytra are long and nearly parallel, with the suture and five longitudinal streaks on each, of pitchybrown; the first not extending to the base, the second and fourth united together near the tip, the third being insulated by them, the fourth much abbreviated at the base, and the fifth slender and submarginal; the feet are slender and simple, the femora being very slightly clavate.

Species IX.-Sienoderus Sinelairi (Plate 56, fig. 3, and 3a, head seen laterally). S. prasino-viridis sericeo-opacus, pcdibus antennisque rufis, thorace utrinque spina armato, elytris tenuissime punctatis et flavido marginatis disco sub-bicostatis, abdomine piccorufescenti.

Long. corp. lin. $4 \frac{1}{2}$.

Syx.-Callichroma (Calliprason) Sinelairi, White, op. cit. p. 277.

Habitat New Zealand, D. Sinclair. IIus. Brit.

The eyes are very large and nearly rounded; the antennæe are 11-jointed, slender, with the first joint long and clavate, the terminal joints rather thicker than the preceding; the thorax is narrowed both behind and before the middle, where it is armed on each side with a spine.

Mr. White considers this insect as a new sub-genus, near to Promeces, Serville, and as one of the links connecting the Cerambycidæ with the Lepturidæ.

Specres X.-Xylotoles griscus. (Plate 56, fig. 2.) X. griseus scutelli margine ely trisque lineolis aliquot brevissimis flavidis; basi punctis impressis apice vix acuminatis, pedibus fuscis femoribus clavatis antcnnisque fuscis.

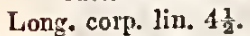

Habitat New Zealaud, Mus. Banks et Mus. Brit.

Syn.-Saperda grisea, Fabricius, Syst. Ent. 186 ; Ent. Syst. 1, 2, 313 ; Syst. El. 2, 324. $X$ ylotoles griseus, White, op. cit. 
Speres XI.-Xylotoles lentus, Newman, Entomol., No. 1, p. 12.

Specres XII.-Lamia heteromorpha, Bdv. Voy. Astrol. 2, 505. I bclieve species XI. and XII. to bc identical with Xylotoles griseus.

Species XIII.-Xylotoles lynceus, White, op. cit. p. 279.

Srv,-Saperda lyncea, Fabricius, Ent. Syst. 1, 2, p. 313 ; Syst. Eleuth. 2, 323.

Described by Fabricius as a native of New Zcaland, from the Banksian Cabinet, in which the typical specimen is still preserred. Its elytra, divergent at the tips, at once scparatc it from the preceding species.

Species XIV._Obrium Fabricianum, Westw.

Sxn._Clylus minutus, Fabricius, Syst. Ent. 192 ; Ent. Syst. 2, 332 ; Syst. El, 1, 2, p. 346 ; Oliv, Ins. 70 ; Fab. 5 , fig. 56.

Nec Obrium minutum, Auct. hodicrn.

Described by Fabricius as a native of New Zealand, from the Banksian Cabinet, where the typical spccimen still exists, although in a bad state of preservation. The species is very closely allied to the following, of which it might perhaps be considered an inmature individual, werc not the joints of the antenna black at the tips.

Srec1fs XV.-Obrium gultigerzu, Wcstr. (Plate 56, fig. 4.)

O. cyaneum nitidum, clytris magis purpurasccntibus basi subtuherculatis, singulo plaga magna meltana rotundata albida parum clevata, articulis omnibus antennarum ad apicen, apicibusqne clavatis femorum nigris. Caput antice fulvo-purpureum, troplis brevibus rufescentibus, mandibularum brevium apicibus nigris, thorax clongatus ante et ponc medium valdo constrictus, mcdio rotundato gibboso. Tibiæ et tarsi pallide testacei.

Long. corp. lin. $2 \frac{8}{4}$

Habitat Port Nicholson, New Zealand. Mus, Parry.

Specres XVI.-Saperda tristis, Fabricius, Syst. Ent. 186, and Ent. Syst. vol. iv., Appendix, p. 453-(whero Fabricius has corrected tho crrors in the transposition of the namcs of the species described by him in rol. i. part $2, \mathrm{p} .314$ of that work, where the S. lineata, from Zangnebar, was described under the name of tristis.)

The species was describcd by Fabricius in his earlier works correctly as a native of New Zealand, from the Banksian Collection, where the typical specimen is still preserved. In the Syst. Eleuth. $(2$, p. 326) by another strange error Fabricius assigns Germany as the native country of the species.

Specıes XVII.-Saperda villosa, Fabr., Syst. Eleutb. 2, p. 320; Whitc, op. cit.

Sy n.-Saperda hirta, Fabr. Ent. Syst. 1, 2, p. 309 (nec. S. hirta, Fabr. Ent. Syst, 1, 2, p. 317, ex Italia).

Described by Fabricius as a native of New Zealand, from the Banksian Cabinet, in which the typical individual is still preserved. 


\section{ENTOMOLOGICAL INTELLIGENCE, NOTICES OF NEW WORKS, \&c. (No. XIV.)}

KixG's College, London.- In the very large collection of objects of nature and art, presented to tho museum of this institution last year by Her Majesty, and which was collected at Kew for the education of the family of King George III., was a considerable collection of insects, made, as it was stated, under the direction of Sir Joseph Banks, and other naturalists, his friends. Having, on the occasion of the opening of this museum, on the 22nd June (1843) had an opportunity of examining this collection, I can but express the disappointment I felt on not finding therein any of those species of insects which Sir Joseph Banks brought home from the islands of the Southern Ocean, of which it seemed probable that duplicates would have been presented to the cabinet of his royal patron. The only insects of value which I obscrved on a cursory view, are Papilio Cressida, P. Harmonia, the latter in fine preservation, as is also a specimen of $P$. Pelaus; several of the large species of AEgeria with very hairy hind legs; several fine species of Mantis and a large species of $X_{y a}$. The collection was kept in glazed drawers, each insect stuck in a small square pastcboard tray, turned upside down, into which some waxen secretion had been poured.

Asmmolean Museum, Oxford.-This very interesting and wellkept collection has recently received a valuable donation, consisting of a cabinet of insects of all orders, from Sylhet or some of the adjacent parts of India, in which many of the new and splendid species recently described by the Rev. F. W. Hope are comprised. It likewise contains several species of Papilio which appeared to me, on a casual examination, to be undescribed, as well as a specimen of the singular P. Payeni, being, I believe, the only specimen of that insect in this country.

Zoolocical Socrety.-The Earl of Derby, President of this Society, has recently presented to it a very extensive and valuable series of insects, from the hilly and hitherto unknown country in tho interior of the south of Africa, lying betwcen $25^{\circ}$ and $26^{\circ} \mathrm{S}$. lat., and $27^{\circ}$ and $28^{\circ} \mathrm{E}$. long., collected by $\mathrm{Mr}$. Burton, as noticed 
in vol. i. p. 174 of this work. In addition to the splendid goliathbeetles, described in my former volume, the collection is very rich in Anthiæ, Graphipteri, a new and singular large species of Cicindela; several new Dromica, several singular Cremastocheili and Longicoln beetles (of which I have made drawings and descriptions for publication in this work). The collection comprises all the ordcrs of insects, and is extremely intercsting in an entomo-geographical point of view. A second sclcction has been presented by the Earl of Derby to the British Museum.

Insects of Sicriy ANd Corfu.-The insects of these two intercsting localities have recently been closely investigated by A. Melly, Esq., and the Rer. Mr. Kuper, who have lately returned home from thence, bringing with them extensive collections, preserved with the greatest care, and comprising numerous scries, especially of minute species of Colcoptera, many of which are quite new, both generically and specifically. An extensive selection of the species from Corfu lras bcen presented to the Entomological Society by the latter gentleman.

Insects from Sylhet, the Kasyah Hills, and the adjacent PARTS of INDIA.-In addition to the cabinet recently presented to the Ashmolean Museum, mentioned above, soveral collections of insects from these hitherto scarcely known districts of India have within the last few months arrived in England. One of considerable extent lias been sent to R. H. Solly, Esq.; another received by the Rev. Mr. Stainforth, was subsequently sold, when the Rev. F. W. Hope obtained the Coleoptera, Orthoptera (containing some splendid Grylli), Homoptera (including some beautiful Fulgoridæ, \&c.), and Mr. H. Doubleday the Lepidoptera. Tho Lepidopterous portion of another large collection, subsequently arrived, has been purchased by the British Museum, in which was comprised the new species of Papilio, figured in Plate 55. The Coleoptera of this collection were purchased by Captain Parry, and the other orders by the Rev. F. W. Hope, who has likewise received another collection from the same country, through the "agency of Dr. Cantor. The Entomological Society of London has also received a considerable collection from Mr. $\mathrm{M}^{\circ} \mathrm{Clelland}$; and within the last fow days I have received a small but interesting collection of Assamese species, from W. Robinson, Esq., of Gowliatti, E. I. containing various new and interesting species, which I propose to figure in future Numbers of this work. 
Histoire des Insectes nuisibles a la Vigne, et particulièrement de la Pyrale, qui dévaste les Vignobles des départements de la Cote d'Or, \& c., avec l'indication des moyens qu'on doit employer pour la combattre. Par M. Victore Audourn. Paris, Fortin-Masson. 1842, large 4 to, 350 pp. 23 coloured Plates.

The publication of this splendid work at length enables entomologists to appreciate the vast loss which their favourite science has sustained in the lamented decease of M. Victor Audouin, and to determinc his legitimate station amongst the "herocs scientiæ." This work clearly shows the manuer in which the study of insects was converted into a science by one of its most talented professors, and at the same time rendered beneficial to the great mass of mankind. It will also clearly prove to those who do not carc to form collections of species, that the investigation of the habits of a single insect is sufficient to prove a great minc of enjoyment, and that entomologists may find sufficient employment for a life without moving far beyond the precincts of their own abodes.

The situation which was so well filled by M. Audouin, united to the grcat interest with which he regarded everything connected with the habits and economy of the insect tribes, especially fitted him to undertake the investigation of the economy of and determine the practicability of remedies against a small Lcpidopterous insect, the Pyralis (Tortrix), Vitana Fabr., whicls had proved extremely injurious to the vines of France, thereby materially affecting one of the great resources of part of the kingdom. The result of these investigations is now given to the scientific world under the auspices of the French Government. And whether wo regard the work as affording a complete view of the natural history of the insect, in all its states, as well as that of its various enemies, as a minute detail of structural peculiarities, both internal and exter$\mathrm{nal}$ of the insect in its different statcs, as a bibliographical notice of the insect, or a practical suggestion and application of remedies, this Memoir cannot be otherwise considered than as one of the most perfect entomological illustrations which has ever yet appcared. The plates are exquisitely engraved, the whole of the anatomical figures being from the pencil of the author himself. Those plates which represent the varions modes and stages of the attacks of the insects upon the vine, are very beautifully drawn and coloured. The whole work, in fact, affords a specimen of what an entomological treatise ought to be. 
Verhandelingen over de NatuUnLye geschiedenis der Nederlandsche overzeesche Bezittingen, \&c. Fol.

Fauna Japonica, sive Descriptio Animalium quæ in Itinere per Japoniam suscepto ann. 1823-I830, collegit Ph. Fr. De Siebold conjunctis studiis-W. De Haan, pro invertebrata elaborata. Lugd. Batav. Fol. Livr. 1-5.

THese noble works are as honourable to their distinguished author and royal patron as they are worthy of the national institution from which they proceed, and of they subjects therein represented. Well, indeed, may the Museum of Leyden hare arrived at its present high fame, when those who contributed to its stores perceive in how fitting a manner their contributions to the national treasures are made available to the scientific world. The work first above mentioned has already been noticed in the 1st volume of the Arcana (p. 47, ) wherein the first part of the entomological portion, comprising the genus Papilio, was shortly mentioned. A second portion has since been published devoted to the Orthopterous insects. In the introductory observations upon each family its entire generic distribution and structural peculiarities are detailed, so that the work cannot in this respect be considered as confined to the Orthoptera of the East. The text of this lirraison is occupied with the families Blattidæ, Mantidæ, and Phasmidæ, a complete list of the Eastern species known to the author being given, together with the descriptions and figures of a great number of new ones, some of the latter being of great singularity. The plates are beautifully executed, and afford a splendid specimen of the capabilities of drawing on stone. Nothing equal to them has yet appeared in this country.

The second work above mentioned is devoted to the Brachyurous and Macrourous Crustacea, which are described and illustrated in a manner which leaves nothing to be desired, (if we except the want of colouring in the plates). The generical and subgenerical details are very elaborate, and all the species are represented of the natural size, several requiring double folio plates. 


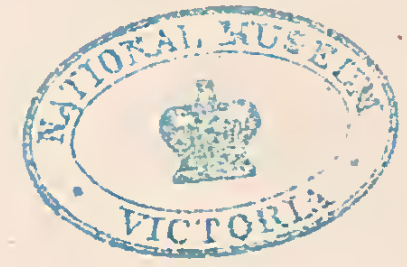




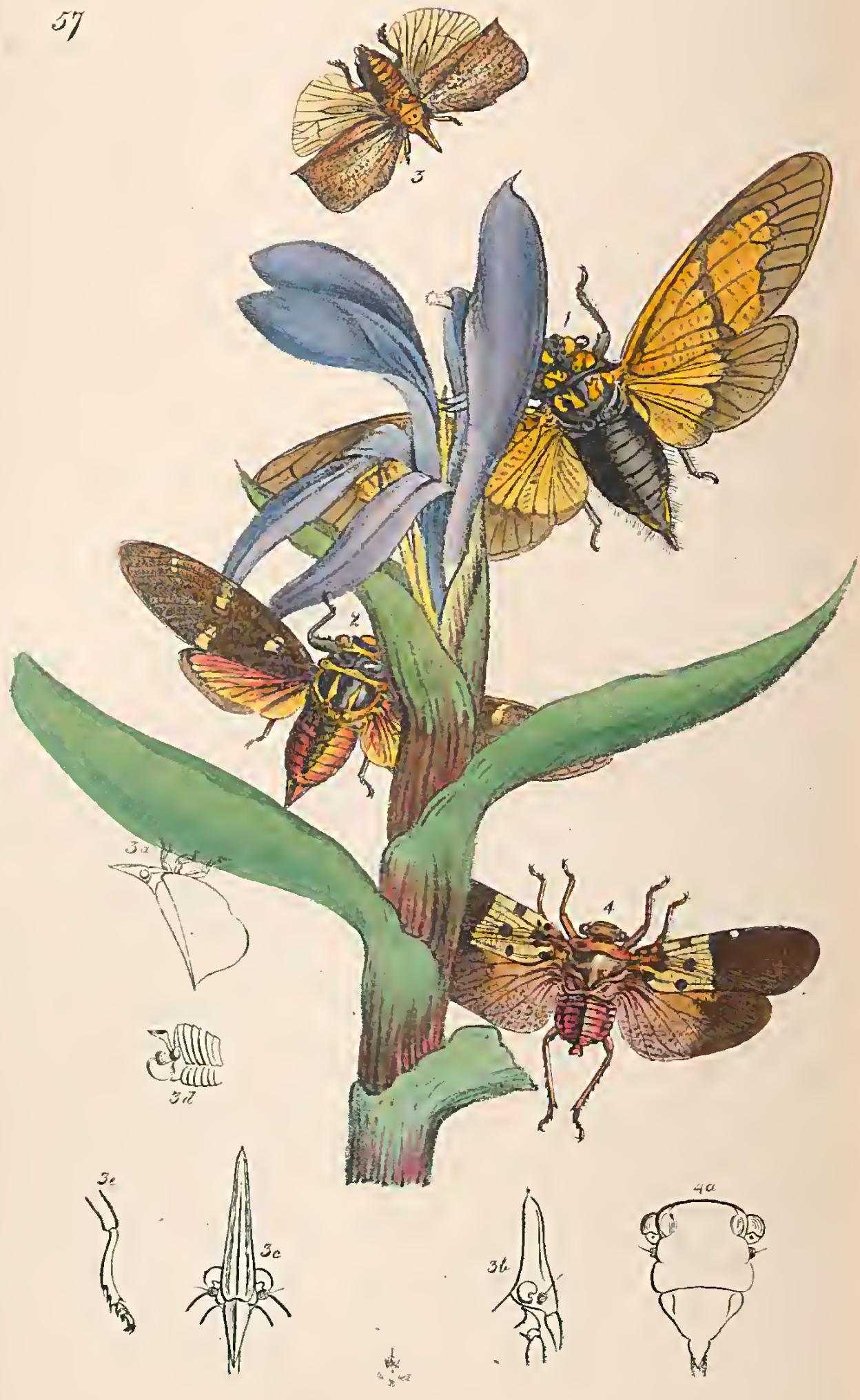




\section{PLATE LVII. \\ DESCRIPTION OF SOME HOMOPTEROUS INSECTS FRONI THE EAST 1NDIES.}

Is a former page (13) I gave a sketch of the arrangements of the species of the genus Cicada, proposed by Drs. Germar and Burmeister. Within the last few days has been published, M. Serville's volume on the Hemiptera, in thc Suites à Buffon, in which, adopting the principle that every group of species logically constitutes a genus, we find the genus Cicada of modern authors broken up into the following genera :-

HOMOPTERA.

AUCHENORHY NCHI (Cicadariæ Latr).

1 Faun. Stridulantes;

1 Tribe. Reticelli;

composed of the genera POLYNEURA, CYSTOSOMA and HEMIDICTYA. (See Are. Ent. 1. pl. 24.)

2 Tribe Octicelli;

1 Group Tosenides (Div. 1, Hcmipteræ Burm.)

G. Tacua.-Type Cicada speciosa Wied. (C, indica Donov. Java)

G. Tosens.-Type C. fasciata Fab. (Java.)

? C. Mearesiana, Westr. Arc. E. pl. 25, fig. 1 (Himalaya.)

G. Pyens.-Type C. Strix. Brullé. R. An. Ed. Crochard. pl. 95. f. 1. (Madagascar.)

G. Geana.-Type C. Maculata Fabl: (Cbina.)

? C. Dives, Westw. Arc. Ent. pl. 25, fig. 2. (Sylhet.)

G. Huғchys.-Type C. Sanguinea, De G. (China)

C. Philiemata, Fabr. Germ. (China.)

C. Incarnata, Gcrm. (Sanguinolenta, Brullé.) Java,

G. Phatypleuna.-Typo C. Stridula Linn. Fabr. (Catcnata, Drury.) (C. G. Hope.) Add C. Capcnsis L.-C. dccora Germ-C. divisa, Germ.-C. hirtipennis Germ,-C. plumosa, Germ.,-C. semiclara, Germ.C. nobilis, Germ.

G. Hearisciera - Typo H. maculipennis, Isap. (yersicolor, Brullé ; sumptuosa, Blanch.) Brazil.

G. Mogannis.-Type M. illustrata* Serville, pl. 9, fig. 4. (Java.)

$$
2 \text { Group. Cicadides. }
$$

With the base of the Eiytra cntirely membranous.

G. Zаммана.-Typc T. Tympanum, F. (Brazil.)

Z. Strepens (C. Tympanum, Pal. B.)

G. Oxypleuna.-Type O. Clara, Servillc. (Africa.)

G. Tetrigades.-Type T. Chilensis, Serv, (Chili.)

G. Cyclochila.-Type C. Anstralasix, Donov. (N. Hall.)

G. Dundubia.-Type C. Vaginata, Fab. (Java)

Add C. chlorogaster, Bdv,; C. doryca, Bdv., Tettig. spinosa, Fabr.

G. Tнорita.-Type Tettig. saccata, Fabr. (China.)

C. perulata Guer. (Port Jackson.)

* This is the Cicada rostellata De Haan, in litt. M. Serville's figure incorrectly represents the fore wings with a dark spot at the tips.

No. XV.-lst SEPTEMBER, 1843. 
G. Fidicina - Type T. Mannifera, Fabr. (Cayenne.)

C. Opalina, Germar. (Brazil.)

G. Crcads.-Type C. Fraxini, C. Ormi.

G. Tıвıcfi, Lalr.-Type T. Sanguinea, F. (C. hæmatodes, Oliv.)

G. TFtтigonyia.-Type T. Vespiformis, Stoll. pl. 29, f. 173 . (Afiris.)

F. Cakineta.-Type C. Formosa Germ. (Polychroa Perty). Brazil. Tettig. villosn Fabr. (C. G. Hope.)

These various genera are entirely established upon external characters, especially the relative size and form of the head, prothorax, and sonorous organs; and, as most of the types of these groups are well known species, I have not thought it necessary to detail their characters.

The two species of Cicada, represented in the accompanying plate, appear to enter into M. Serville's genus Gxa:1a; the fore-wings being entirely opaque (Syn. art. 720), the sides of the prothorax not dilated (art. 726), and the front of the head rounded (art. 727.) There is, however, considerable diversity between these two species in the comparative breadth of the wings.

CrCada pulchella, Westw. (Plate 57, fig. 1. + )

(Royle's Himalaya, pl. 10, fig. 2.)

Nigra capite thoraceque sulphureo-maculatis, alarum dimidio basali sulphureo (in alis anticis fascia nigricanti obliqua diviso) apicibus llavido-fuscis, venis in partibus obscuris nigris. Expans. alar. uic. $3 \frac{3}{6}$.

Habitat in Hinalaya, \&ic. Mus. nostr. \&c. ô, 우.

The abdomen beneath and on each side at the extremity is spotted with yellow, the fore-wings are broadly wrinkled as in C. maculata, and the drum-covers of the male are small, leaving the striated internal membrane broadly exposed.

\section{CICADA 8-NOTATA, Westw. (Platr.57, fig. 2. \%)}

Nigra, capite fascia frontali et postica, fasciaque postica prothoracis metathoraceque flaridis, mesothorace lineis duabus irregularibus flavidis, abdomine sanguineo segmentis basalibus supra in medio nigro maculatis; alis anticis fusco-nigricautibas, singula maculis 4 al bidis venisque tenuissimis rubris; alis posticis sanguineis nigro-limbatis.

Long. corp. lin. 11 $\frac{2}{2}$. Expans, alar. unc. 2, lin. 7 .

Hahitat in Assam. Mus. Westrw. ô, ㅇ․

I am indebted to Mr. Robinson for this interesting novelty, which is closely allied to C. dives W. figured in pl. 25 of this work, from Sylhet. Like that species, the present has rather narrow fore-wings, which have the surface very closely wrinkled with transverse furrows. 
Genus.-CYRENe, Westu.

Corpus bieve crassum abdomine compresso. Caput fronte conico longo, porrecto, apice acuto, supra ad latera carinatum, carinis ante apicem obliteratis, postice ad prothoraccu cxtensis. Oculi magni latcrales subtus emarginati (fig. 3 a, 3 b). Ocelli nulli. Antenno parvo suh oculos inserta. Promuscis mutilata, Prothorax mesothoracis longitndine, disco punctis duobus in medio impressus. Hemelytra coriacca opaca homogcnea convexa laia, margine antico sinuato apicc rotundato, angulo postico acuto; venis parum ramosis. Pedes breves robusti, tibiis posticis curvatis, intus versus apicem 3-spinosis (fig. $3 e$ ). Abdomen apice truncato in lobos duos terminatum, appendiculo tenui erecto apice concavo instruetum. (Fig. $3 d$.)

The entire surface of the hemelytra of this new Fulgorideous genus is covered with an immense number of minute circular elevated areas, visible only under a lens. I have observed notling similar in any other Fulgorideous insect. When at rest, the wings are carried almost perpendicularly, as in fig. $3 a$.

Species unica.-CYREne guttulat A, Westw. (Plate 57, fig. 3 \& 3 a.)

Fusco-brunnea, proboscidc picea, abdomine rufescenti, bemelytris guttulis nonnullis minutis albidis alterisque duobus (in singulo) nigris, alis posticis fuscis. Long. corp. Jin. 7. Expans. alar. lin. 14.

Habitat in Insula Sumatra. D. Raflles. In Mus. Soc. Zool. Lond.

\section{LYSTRA TRICOLOR. (Plate 57, fig. 4.)}

Sanguinea glaberrima, prothoracis lobo antico mesothoraceque anticc nigris, henelytrolum dimidio basali (basi ipso livido excepto) stramineo nigro maculato; apicali brunneo, macula costali straminea; posticis rubris dimidio apicali fusco, pedibus castaneo-sanguineis.

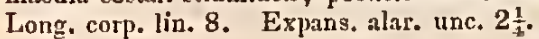

Habitat in Assam.

I am likewise indebted to Mr. Robinson for specimens of this beautiful addition to the Fulgoridæ, from a country which appears to be extremely rich in the species of that family, judging from the splendid insects described and figured by the Rev. F. W. Hope in the new Part of the Transactions of the Linnean Society.

The present species has the face (fig. 4a) convex and very glossy, nearly square, with the sides rather deeply impressed; the eyes are rather slightly emarginate beneath, leaving a small space in which the ocelli are placed. The disc of the liead is excavated and marked with two ocelli-like tubercles placed wide apart. The four fore-tibire are slightly compressed, but are without any tendency to foliation.

The plant represented in the plate is Roscoea purpurea, from Upper Nepaul. (Smith, Exot. Bot.) 
THEY may boast of the spring-time when flowers are the fairest, And birds sing by thousands on every green tree;

They may call it the loveliest, the greenest, the rarest,But tlie summer "s the season that 's dearest to me!

For the brightness of sunshine; the depth of the sladows; The crystal of waters; the fullness of green;

And the rich flowery growth of the old pasture inearlows In the glory of summer can only be seen.

Oh the joy of the greenwood! I love to be in it, And list to the hum of the never-still bees; And to hear the sweet roice of the old mother linnet, Calling unto her young 'mong the leaves of the trees!

To see the red squirrcl frisk hither and thither, And the water-rat plunging about in his mirtl, And the thousand small lives that the warm summer weather Calls forth to rejoice on the bountiful earth !

Then the mountains, how fair! to the blue rault of heaven Towering up in the sunshine, and drinking the light, While adown their deep chasms, all splintered and riven, Fall the far-gleaming cataracts silvery white!

Oh the beautiful flowers, all colours combining,

The larkspur, the pink, and the sweet mignonette, And the blue fleur-de-lis, in the warm sunlight shining:

As if grains of gold in its petals were set?

Yes, the summer,--the radiant summer's the fairest, For greenwoods and mountains, for meadows and bowers, For waters, and fruits, and for flowers the rarest, And for bright shining butterflies, lovely as flowers!

Mary Howtt. 


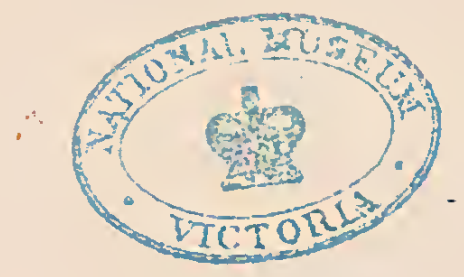




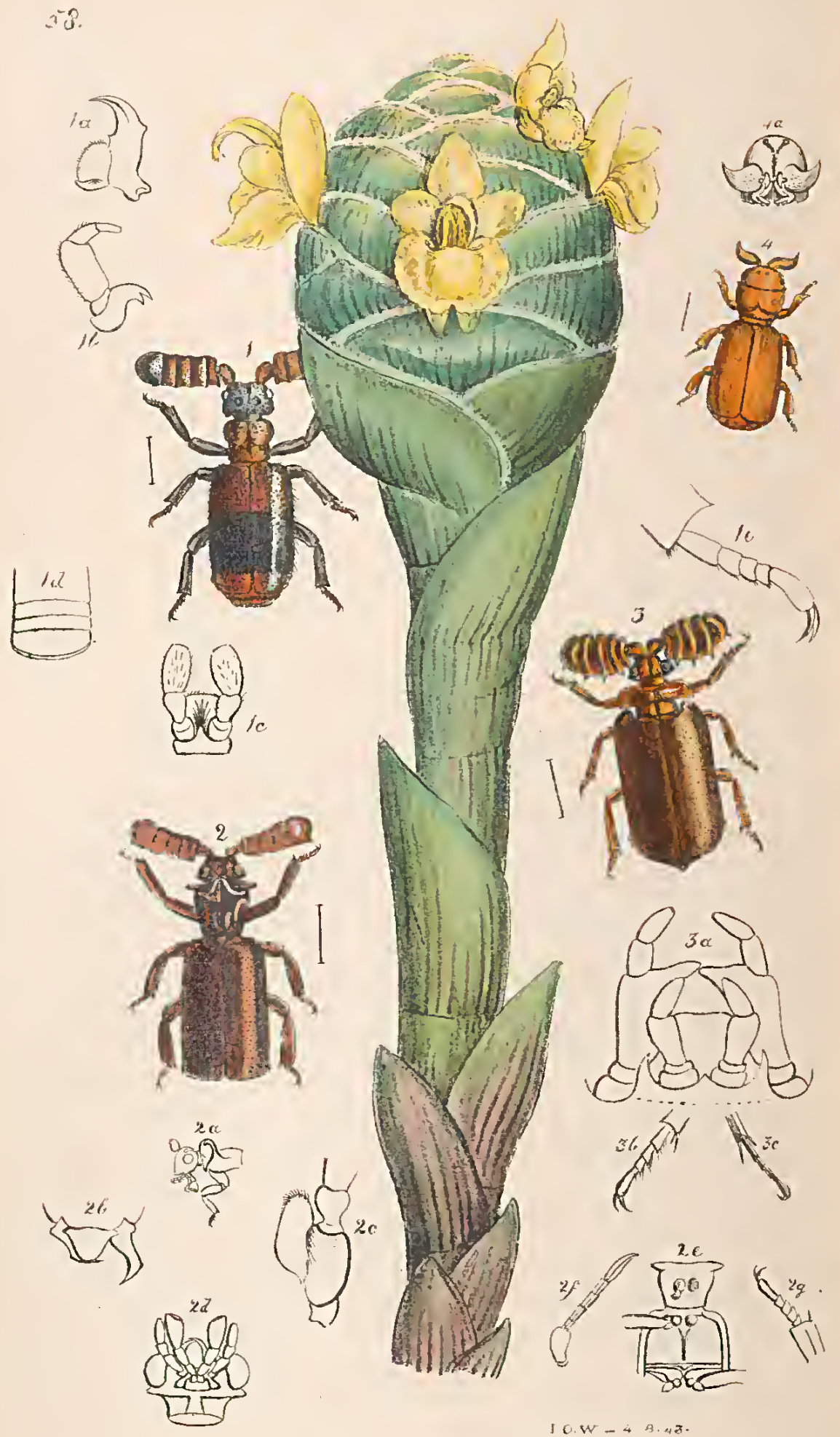




\title{
PLATE LVIII. \\ MONOGRAPH OF THE COLEOPTEROUS FAMILY PAUSSIDE.
}

\section{PART II.}

THE three following species, constituting the like number of genera, form a peculiar section in this singular family, possessing, in the number of joints in their antennx, an intermediate character between the Cerapteri and more typical Paussi and Platyrhopali.

\author{
GENus.-CERATODERUS, Westwood. \\ (Procerdings Linn. Soc., June 1, 1841.)
}

(Plate 58, fig. 1.)

Corpus oblongum dcpressum punctatnm. Caput transverso-quadratum, angulis rotundatis, supra plaui usculum, postice collo instructum, angulis pone ocnlos rotundatis, disco inter oculos bi-impressum; antennse q̨ussi 6-articulats; articulo 1mo subcylindricn, 2-5 (intermediis) transversis plauis, ultimo semiorbiculari. Manjibula (fig. 1 a) falcatæ, apice acutac, margine externo et interno in incdio angulatis, basique intus lobo semipellucido coriacco instructa. Maxilla minu tæ (fig. I b) planse cornex apice acutx, curvatæ, intus sub apicem dente acuto armatx. Palpi maxillares $t$-articulati, articulo lmo minuto, 2ndo nagno osato, 3 tio 4toque minoribus gracilioribus subcylindricis. I[cntum brevissimum (fig. 1 a) usclio acutè producto. I abium integrum corncum ad apiccm articuli $2 d i$ palpornm labislium protensum. Palpi labiales crissi articulo ultimo prexcedcrte haud multo majori, ovato, apice truncato. Prothorax capito vix latior, cordato-truncatus, trans modium linea impressa notatus. Scutcllım miuututu. Elytra oblongo-orata depressa, angulis oxteruis apiealibus tubcrculo ordinario munitis. Pedes breviusculi; femoribus tibisquo compressis, his ad apicem setigcris (fig. \& e) laud calcuratis; tarsis distincte 5 artiłulatis, articulo basali Beq̨uenti longiore; 1 to praecedenti parum minori. Ungues magni acuti. Abdomen (fog. 1 l) c scgmentis 4 constans, duobus intermedis brcribus.

Specres unica.-Ceratoderus tifasciatus. (Plate 58, fig. 1.) C. ferrugineus; capite, antennarum apice, lascin lata elytrorum, fcmoribus tibiisque nigris. Long. corp. lin. 3.

Habitat in India Orieutali. lin Mus. Inp. Vindob., et Hupe.

Srw.-Paussus bifascialus, Kollar in Ann. Wien. Mus., 1836, t. 31, fig. 7 a 6 ; Westw.

in Trans. Ent. Suc. ii. p. 91, pl. 10, fig. 3; Westw. in Proceed. Linn. Soc., ut supra.

Caput nigrum, nitidum sat reuso te punctatum, impressionibus dnabus laevioribus.in medio lincaque tenui impressa longitudinali in verticem, oculi laterales vix proninuli rotundati uigro-obscuri ; iustrumenta cibaria ferrugiuea. Antcnnge ferruginea puuctatre articulis duobus apicalibus nigris. Prothorax ferrugineus nitidus, lincola transversa uedia profundc impressa, al tcra lougitudínali miuus profunda nec margincu anticum neque posticum atiugente; lia lineoles crucem in suedio thoracis represeutant. Elytua thoracis parte antica latiora, obluuga-quarlraugula, basi ipsa dcpressa, prothorace remota subemarginata, lateribus inflexis imnarginatis, apice truncata, et au angulos tuberculo ferruginco instiucta ; abdomine brevion convexiuscula ferruginea nitida obsolctissirnc-puuctata, fascia Iata mediana nigra. Corpns snbtus ferrugineum, uiljum punctatum. Pedes nigri omnes subrequales tibiis compressis femoribus basi tarsisque totis ferrugincis.

This pretty species was described by Professor Kollar fronl a unique specimen in the Vienna Museum, brought from India by Fitchel many years ago, and which is, I apprehend, the identical insect mentioned by Donovan in his Insects of New Holland, as an undescribed species of Cerapterus. My drawing is marle from a 
second specimen, which lias been recently added to the fine collection of the Rev. F. W. Hope, who, with his usual liberality, allowed me to dissect it for the purpose of illustration in this work.

\section{Genus PEntaplatartitrus, Westw. (Plate 58, Fig. 2.)}

('Trans. Lim. Soc, Vol. 16.)

Corpus subdepressum capite parvo prothorace majori clytrisque latioribus oblongo-quadratis Caput thorare angustins depressum, subqundratum angulis posticis pone oculos subacute prominulis; postice collo brevi instructum : oculi mediocrcs latcrales ovales. Antennæ ad angulos anticos verticis insertar. capito entm prothorace paullo loogiores, quasi 6-articulata, articulo $1 \mathrm{mo}$ cylindrico brevi, posticc subemargioato, tunc articulus? parvus subglobosus in apicem prionis inscrtus, cui insidet articulus 2 dus verus brevis transvereus subpunctatus, 1 mo fere duplo latior plantrs, apice trunca to ; articuli 3,4 , ct 5 longitndino lmi at illo triplo latiores, plani transversi, artieulus ultimus planus, paullo major spice cireulari margineque extcruo vel postico in augulum parvum producto (tig. is $f$ antenna latere visa). Os infertum (fig. $2 d$ ). Labrun (fig. $2 f$ ) par vum crustaccum subtrinugu. lare margine antico rotunda to basi ntrinque oblique truncato. Mnndibula (fig. 26 ) parrx cornex elongatio curvata lobo basali cxterno, apiee acutse ct cxterne angulom formaotes. Maxillæ, labium, et palpi ex cavitatis oralis margine jufero et transverso parallelo pro. dcuntia. Palpi clongati, labialibus clavatis maxillares longitudine requantibus, lis gracilioribus. Maxillwe (fig. 20 ) patrse lobo apicali magno inermi apice subhirto. Palpi maxillares lougi cylinurici articulis 2 ct 4 longioribus, hoc cylindrico-eunico. Nentum (fig. 2 d) transversum rigidum angulis anticis ganllo productis. Labium interaum mentoque longius et angustius subtriangularo apice trausverso. Palpi labiales in serpos duos corneos inter mentum et labium inscrti, articulis tribus, lno brevi, 2do illo duplo longiori, 3sio magno clavato apice oblique subtruncato. Prothorax subquadratus et sub. cylindricus antice latior angulis porrcetis. Seutcllum parrum triaugulare pedsnculo abdouinis inmersum. Mctasternum (fig. $2 e$ ) magnum transversum medio linea longitudinali linenque transversa subapicali impressum. Elytra oblongo-quadrata lævia, dorso plana, ad latern deflexa immarginata, postiee truncati angulisque tnbercnlatis. $\mathrm{Al} 2$. (Abdomcn in speciuine nostı nutilatum). Peles omnes similes breves valde compressi lati. Tibiæ ounnes spinn minutissima tcrminalt internè instrueti (fig. $2 g$ ). Tarsi breves subeylindrici, articulis 5 integris articulo luio brerissimo, tribus proximis breribus æqualibus subens paullo setosis, articulo ultimo longitudine quatuor pracedcotium, cylindrico apice paullo crassiori, nnguibus 2 lus validiusculis acutis simplicibus.

In general appearance, and in the formation of the prothorax, this genus resembles the species of the first scetion of Paussus; whilst the formation of the antenna leads towards Cerapterus, with some of the species of which it also agrees in the incrassation of the labial palpi. Between the anterior part of the eyes there are two slightly raised tubercles, the centres of which appear excarated for the reception of a circular ball, probably capable of a rotary inotion, upon the upper or exposed surface of which the lower part of the basal joint of the antenna is inserted.

Speeies unica. PENTAPlatarthrus PAUSSOldes. (Plate 58, fig.2.)

P. totns rufo-piceus, thoracis angnlis an ticis utrinque in spinam obtusam productis et iu ucdio an tice sulcucullato (fig. 2 a) dorsoque in medio profunde cxcavato.

Long. corp. lin. 3 s. Lat. corp. ad bas. clytr. lin. $1 \frac{1}{3}$.

Habitat in Africa Australi. 1o Mlus. Hopc and nostr.

Caput punctatum picoum, vertico paullo excavato. Antennac rufo-picex articulo 1 mo punctato, a picalibus levissimis. Thorax lxvis nitidns, rufo-piccus, angulis anticis utrinque in spinam breven obtusiu productis, antico subcucullatus, disco in medio profuade excavato, inde carina longitudinalis ad ucdium marginis postici ct utrinque linea elevata cum margine laterali parallela. Elytra rufo-picea nitida tenuissinc punctata, punctis in linens
perpaucas versus suturam dispositis. 
Genus LeBIOderus, Westw. (Plate 58, fig. 3)

(Traus. Bint. Soc. vol. ii. p. 93.)

Corpus subdepressum latiusculum. Caput thorace multo angustius postice iu collum breve contractum, subtriangulare, antice truncatum subemarginatum : angulis posticis pone oculos subacute productis; rertice linea impresso. Palpi maxillares (fig. 3 a) maximi 4 -articulati, articulo $1 \mathrm{mo}$. Grevissimo; 2ndo. maximo, iuterne sensim ad apicem in lobum magnum acutum producto, articulis duobus apicalibus mul to minoribus subæqualibus, ultimo obovali apice in vesiculam parvam terminato. Mfentum eum cnpito haud articuiatnm (3a) transversum, nngulis anticis líteralibus aente productis denteque parvo breviori centrali instructum, palpi labiales 1 -articulati, articulo 1 mo. parvo emsso, 2ndo. brevi annuliformi, 3 tio. longiori apice latiori; ultimo prsecedentis longitudino graciliori oblongo-ovato. Antenna maxima, ut videtur 7 -artienlatte, articulo 1 mo brevi ovali, 2do. minutissimo, reliquis 5 latissinsis massam ovatam subdepressam, disco marginibusque irregularibus, formantibus. Prothoras latus transversus, el ytrorum fere latitudine, depressus, lateribus anticis ro\&undatis et in lobum utrinque productis, postice truncatis : portiouo postica prothoracis multo angustiori. Elytra lata oblongo-quadrata : lumeris antice ct oblique productis: angulis posticis tuberculo ordinario munitis. Alæ 2. Pedes satis graciles compressi, tarsis ut videtur, 4-articulatis, articulis 3bus. basalibus subsequalibus ;" (in certo situ rudineutum articuli fere ad basin articuli ultimi apparet). Abdomen elytris paulio longius apice acumirato, 4-annulatum.

This genus appears to be intermediate between Platyrhopalus (with which it agrees in the comparative shortness of the terminal joint of the labial palpi and in the structure of the maxillary palpi,) and Pentaplatarthrus, with which it might be associated, on account of the number of joints in its antennæ.

It is, however, abundantly distinct from these and the other genera of the family; whence I proposed a new genus for its reception, with a name alluding to the structure of the prothorax, which bears some resemblance to that of Lebia and Masoreus in the narrowness of its posterior part, although it will be evident that here it is the anterior lateral angles, and not the posterior part of the prothorax (as in those genera) which are dilated into lobes. Platyrhopalus aplustri$f e r$ has the prothorax somewhat similar in form, but the antennæ have the club not articulated, although with evident traces of constrictions, and with the hind margin armed with spines.

\section{SPECIES UNici. LEBIODERUS GORII.}

(Plate 58, fig. 3.)

Testaceus, tenuissime punctatus; clytris paullo saturationibus, antennarum clava margine postico 4 -dentata.

Long. corp. lin. $3 \frac{1}{2}$.

Habitat in Insula Java.

In Mus. Gory et Buquet, Parisiis, et nostr. Amicissime communicavit D. Westermann.

Testaceus, supra subdepressus tenuissime punctatus nitidus. Caput porrectum subtriangulare, antice subemarginatnm, angulis postieis pone oculos acutis et paullo productis, vertice linea impressa notato. Antennæ pilosx, clava quasi 5-articulata, articulo 1 mo. rcliqnis minori trausserso, tribus sequentibus latioribus, supra ct subtus carina clovatn instructis, ultimo obtriangulari apice rotundato: articulis 4 ultimis ar marginem posticum dente parvo et gracili armatis. Prothorx rufo-testaceus nitidus puuctatissimus, in medio disci paullo convexus, linea jarum impressa centrali notatus. Scutellum parvum triangulare. Eiytra rufo-testacen nitidissima punctatissima, protloracc latiora, humeris antice et fere ad marginen posticum loborum prothoracis productis. l'edes tcuucs compreesi coneolores.

This species is named in honour of M. Hippolyte Gory, one of the authors of the "Monographic des Cétoines," by whose kindness 
in sending his unique specimen of it from Paris for my examination, I was first made acquainted with this interesting genus. My collection has subsequently been enriched, by the liberality of Mr. Westermann, of Copenhagen, with a specimen, from which the present figure is taken, and which may possibly be of a different sex to the specimen which I figured in the Transactions of the Entomological Society of London. (Vol. II. pl. ix. fig. 8.)

\section{Grovs HYluTORUS, Dalman. (Plate 58, fig. 4.)}

Corpus subdeprcssum breve, capite lato in thoracem postice fero ad oculos immerso, elytris thorace paullo latioribus apico trancatis. Caput uaguun couvexum rotundatum collo nullo, fovea magna ovata, impressiono profunda inter oculos ct autennartmi basin pro receptione clave antcunarum (fig. $4 a$ ), ocellis $v e l$ tuberculis dnobus verticalibus numillatis. Trophi nomlum descripti. Oculi parvi. Antenure capite vix lougiores articulo Imo. brevi in lato medio emarginato, 2ndo. parro subghobiso, cmarginatura prioris inserto, ultimo magno (magnitudino capitis diwidio) orato lancedito, conpuresso subtus rel posterius couvcro, supra vel anterius concavo, npice acuto antroisum flexo. J'rotlorax brevis, transversus antice inulto latior, capiti aqualis et illud ambiens basi apiecque truncatus, supra inæqualis presertim pone medium. Scutellum mediocre triangulare. Elytra thoracis antico vix latiora oblongo-quadrat apice truncata anum occultnutia ; supra convcxa. Als anpla. Abdomen breve retusum. Peles hreves validi femoribus tibiisque valde compressis dilatatis, tarsis brevibus eylindricis ut videtur 4-articulatis, primis tribus brevissimis coaretatis pilosis, 4to longiore undo, uuguibus parvis arcuatis.

The detailed specific description of Paussus bucephalus, given by Gyllenhal in the Appendix to Schonherr's Synonymia Insectorum and the accompanying fignre (copied in my plate), together with Dalman's observations on the species in the Analecta Entomologica, are the only materials which have hitherto been published, ex visu, of the type of this genus, which differs in several respects (such as the large size of the head immersed into the thoracic cavity, the small eyes, and existence of ocelli) from the other species of the family; indeed, Mr. MacLeay considers that it does not belong thereto. Its general habit appears to me, on the contrary, to be decidedly Paussideous, agrecing with several of the forms of the family in its antennæ, sub-bipartite thorax, short broad feet, colours, and truncated elytra. SPECIEs vica.-Iylotorus Bucephalus. (Plate 58, fig. 4.) Pallide testaceus glaber,
ocnlis nigris, thorace postice tratusverse-sulcato.

Sxi.-Pausus Bucephalus, Gyll. in Sch. Syn. Ins. i. p. 3, App. p. 15, tab. 6, fig. 2 and $2 a$; Dalm. Anal. Eut. p. 103 (Hylotorus B.) Latr. Règne An., 2 d Edit., v. p. 93; Westw. Trans. Liun. Soc., vol. 16, p. 654.

Ilabilat iu Sierra Leonc, Africa. D. Afzclius. Mlus. Schonherr.

Long. corp. (e fig. Selionl.) liu. $2 \frac{1}{3}$.

Mlagnitudine drobii mollis et colore similis, pallide testaceus glaber, nitidus. Caput fronte linea impressa, postice bifida, ramulis in tuberculis duobus vel ocellis desinentibus. Oculi nigri ; antennic corpore concolores. Prothorax supra inæqualis paullo pone medium striga angulata valde profunda et antice posticeque aliis obsoletissimis transversin impressis. Scutellum concolor. Elytra testacea nitida, lacia. Alae fusco lyalinæ. Corpus subtus lestaceum punctulatum. Pedes pallide tcstacei.

The curions plant represented in the plate is the broad-leared ginger of the East Indies, Amomum Zerumbet of Linnens. 


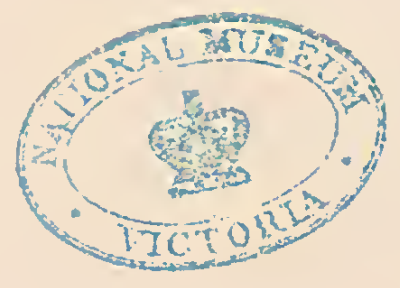




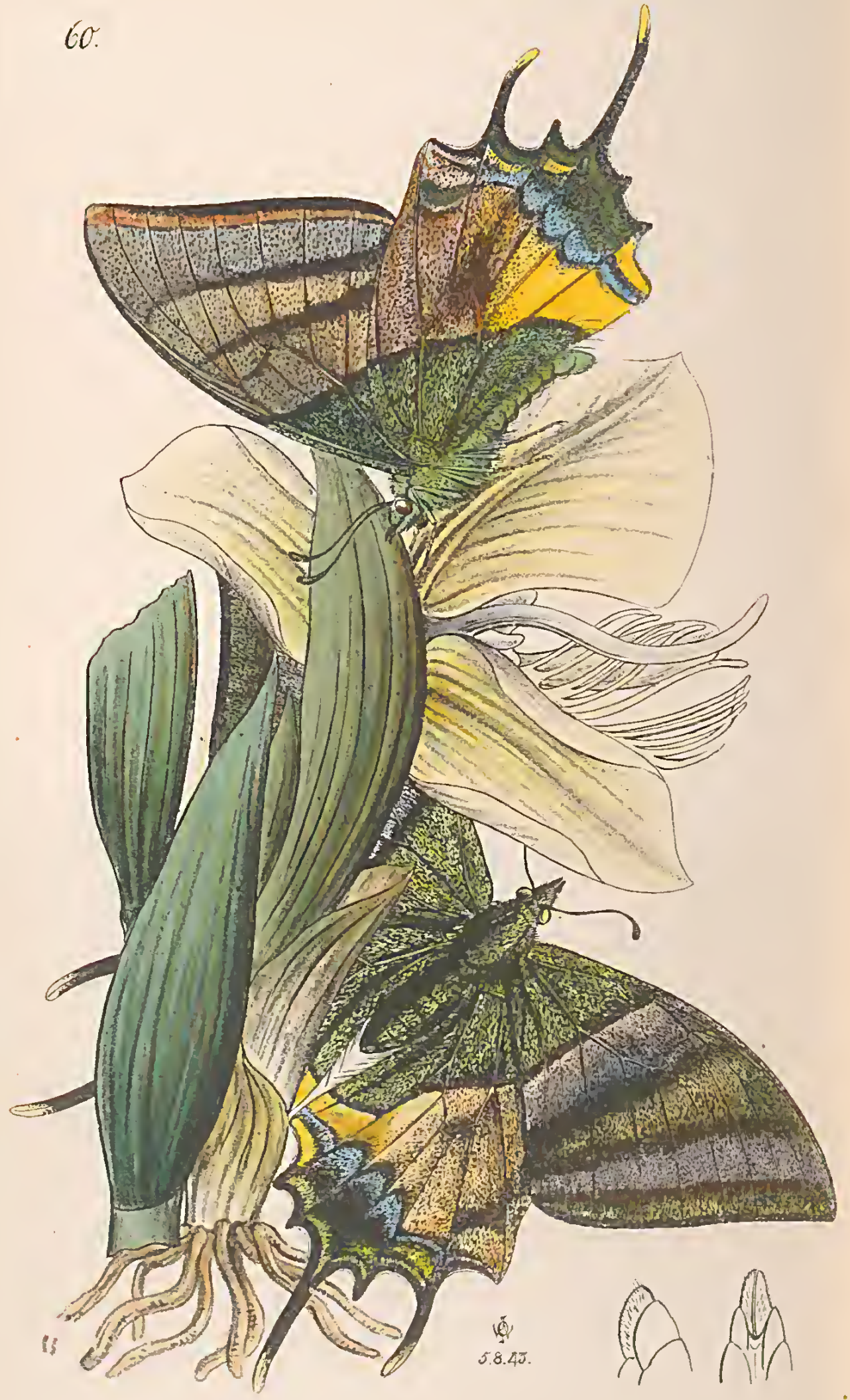




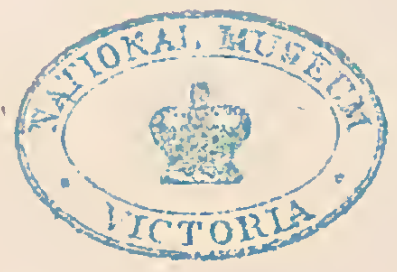




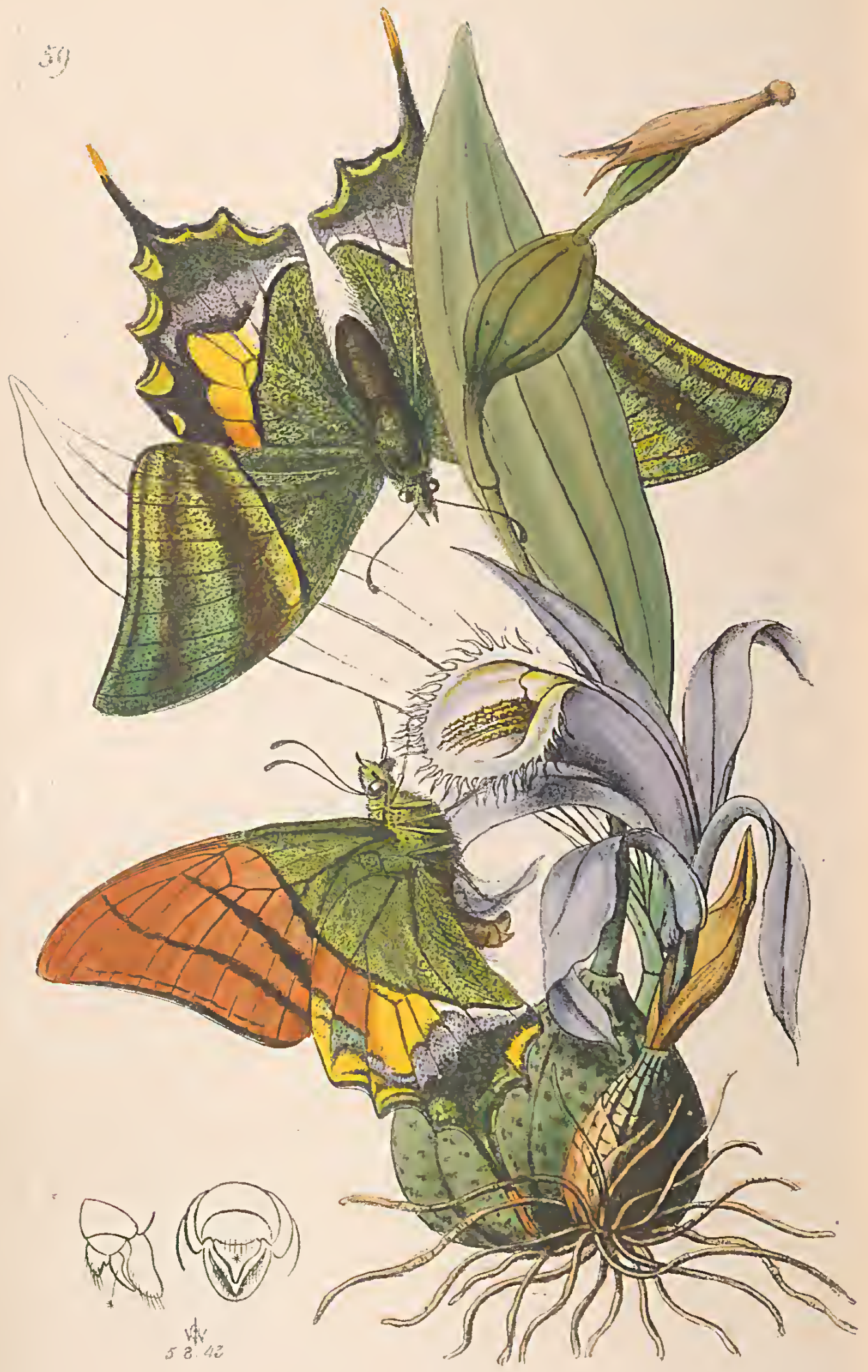




\author{
PLATES LIX AND LX. \\ DESCRIPTION OF A NEW GENUS OF PAPILIONIDA.
}

THE recent arrival in this country of specimens of a new and very decided genus in the family Papilionida (a group of comparatively smill cxtent as to generic forms), is an event of too much interest, in respect to a work, of which so many plates have been devoted to the illustration of that family, to render any apology necessary for giving coloured figures of these new and splendid insects in the "Arcana Entomologica." I should not, however, have done this, had I not been informed that it was the intention of the Linnæean Society to publish uncoloured representations of them, accompanying Mr. Hope's Memoir, in which they have been described. In this Memoir Mr. Hope has proposed for them the generic name of

TEINOPALPLS,

in allusion to the porrected palpi, a character in which they differ from all the other Papilionidx, and in which respect they resemble some of the Nymphalidx. Not only are the palpi porrected, but the front of the head is conically produced and clothed with very delicate hairs. The eyes are large and lateral, the antennze rather short, with the club gradually formed.

The thorax is very robust, evidently proving the inscets to be more powerful on the wing than the other Papilionida; the forewings are large and triangular, with the tips acute; the apical margin in one sex more falcate than in the other. The lind-wings are deeply incised along the margin, the incisions becoming tails in one sex; besides which they are furnished with a long narrow tail common to both sexcs in the ordinary position. The fore-wings have the discoidal cell closed at the tip, and emitting the four branches which are the absolute eharaeter of the Papilionida; whilst the posterior branch of the subcostal vein (which ordinarily branches off from the middle of the transverse vein which closes the cell at its extremity) here arises close to the emission of the subcostal vein itself from the anterior angle of this cell. In consequence of this arrangeinent, it is necessary that the fourth branch of the median rein should be more curved than in the other butterflies of this 
family. In the hind-wings the veins are arranged as in Papilio. The fore-fcct are perfeet, the tibia being calearated at the middle on the inside. The two spincs at the extremity of the four hind tibire are short; indeed the legs are comparatively shorter than in most of the species of Papilio.

It is searcely questionable that the two specimens represented in the aecompanying plates, are not the sexes of one species for whieh the name of $\mathrm{T}$. imperialis should be retained, as being that proposed for the male inseet (plate 59). I regret that in consequence of Captain Parry (to whom these insects belong, and to whose kindness I am indebted for permission to figure them) possessing but single speeimens of each sex, I have been prevented from determining the preeisc strueture of the sexual organs, which differ from all those figured by M. De Haan. In one sex, however, thcy are furnished with a horny piece, broad at the base, reecived into a kind of anal pouch, (see outline figures at foot of pl. 59), whilst in the other they arc eomposed externally of two flat oval pilose lobes, (sce ontline figures in $\mathrm{pl}$. 60.)

\section{'TEINOPALPUS IMPERI ALIS, Hope. (Plate 59.)}

Alis supra viridi-pulverosissimis striga tenui communi, ante mediuu, in antiejs nigra, extus fiavo marginata nebulisque dualus obscurioribus subapicalibus; posticis maeula magna flava nigro-eineta in lineam areuatum albam desiuente squamulis cinereis lunulisque marginalibus flavis viridibusque; omnibus sulitus aurantiis nigro-striatis, portione basali virid, posticarum apicibus nigro, griseo, viridique rariis.

Expans. alar. une. 3, lin. 10.

Habitat in India Urieutali. Syluet. In Mus. D. Parry.

\section{TEINOPALPUS PARRYæ, Hope. (Platc 60.)}

Affinis præeedenti at major, alis obscurioribus, omnibus basi viridibus; anticis minus falcatis, nebulis einereis nigrisque transversim strigatis; postieis bicaudatis, plaga magna mediana pallide lutea nigro pulverosa, strigaque undulata nigrs extus griseo pulverosa, lunulisque marginalibus vilvidibus flavisque oruatis, angulo anali late flavo.

Expans. alar. une. 4 ; lin. 7.

Habitat in India Orientali. Sylhet. In Mus. D. Parry.

This supposed species, if indeed it be not the female of the preceding, las been named by Mr. Hope, in honour of the lady of Captain Parry. Dr. Horsfield has shown me a speeinen of it in the colleetion of the East India Conpany, and Mr. A. White informs me that there are specimens of it in a collection at Edinburgls.

The plant represented in pl. 59 is the Nepalese Epidendrum pracox, and that in pl. 60 is Orchis gigantea, from the same country, both first deseribed in Smith's Exotic Botany. 


\title{
ENTOMOLOGICAL INTELLIGENCE, NO'IICES OF NEW IVORKS. \&c.
}

\author{
(No. XY.)
}

SUITES A' BUFFON, Formant, AVEC LES GUVRes de CET AUTEUR, UN cours complet d'histoire naturelle, 8ro, with Plates.

Crustacés. Par M. Milne-Elwards. Tow. I, 1834 ; tom. 2, 1837 ; tom. 3, 18.10, (completed).

Apteres. Par M. le Baron Walckenaer. Toms. 1 and \& 2, 1837, (Genus Aranea Linn. completed in these two volumes.)

Introduction A L'Entosologiz. Par M. Th. Lacordaire. Tom. 1, 1831 ; tom. 2, 1838 (completed.)

Hyménopteres. Par M. le Comte Amédée Lepelletier de Saint-Fargeau. Tom. 1, 1836, (Social Formidx, Vespidx, and Apidæ). Tom. 2, 1841, (Solitary A pida, Parasitic Apidæ, and Sulitary Vespidæ).

Orthoptìn rs. Par M. Audinet Serville, 1839. 1 tom. (completed).

Lèninoptères. Par M. le Doct. Boisduval. Tom. 1, 1836 (Papilionides and Pierides only).

Drptères. Par M. Macquart. Tom. 1, 1834 ; tom. 2, 1835 (completed).

Néurortéres. Par M. Rambur. 1 tom. 1842 (completed).

Heniptikes. Par Messis. C. J. B. Amyot and Audinet Serville. 1 tom. 1843 (completed).

Wuen will the state of science in England allow of the publication of such a series of volumes, each averaging upwards of 600 pages, as are contained in the preceding list? And yet several portions of the series still remain incomplete; whilst of the great order Coleoptera, no part has yet appeared, and of tho Lepidoptera only a very slight portion. It was surely a most excellent idea to unite the talents of so many excellent authors in one general work, whilst each was left so cntirely uncontrolled, as to the manner in which the subject of his portion was to be worked out, that the series possesses all the advantages of separate treatises. How many excellent general works liave beell spoiled by the various contributors being tied down to some plan settlcd by in editor perhaps ignorant of the subject! Still, however, there are some points on which it would have becu serviceable to have iuposed uniformity, as, for instance, in the employment of short Latin characters prefixed to each species, the addition of generic tables at the head of each family, Sc. As it is, we liave the specific character sumetimes at great length (whicl causes a terrible waste of time in ascertaining species) and this sometimes 
in French and sometimes both in French and Latin (whole pages of Latin descriptions, followed by a verbal translation in French), whilst sometimes the description is confined to a few lines. The only author who has followed the good old Linnæan plan of giving a short Latin specific character at the head of the description of each species is M. Rambur, and even he has confined this to the first lalf of his volume, the remainder lraving only French descriptions.

The last published volume is that on the Hemiptera, by Messrs. Amyot and Serville, in which we find fresh cause for desiring more uniformity in these works. The latter author has been so long and advantageously known as an author devoted to the study of the mandibulated and haustellated Hemiptera of Linnæus, and especially by the publication of his volume on the Orthoptera in this series, that when we perceive the alterations in the style exhibited by the present volume, as contrasted with that last mentioned, we can but lament that an association with another autlor has evidently led to such modifications.

The first matter treated upon in the introduction to the volume is the nature of Genera; and liere we find the authors (perlaps unconsciously) adopting the argument made use of by Mr. Vigors in the Zoological Journal, namely, that "un genre n'est pas autre chose qu'une division méthodique venant immédiatement au-dessus du dernier dégré de division, qui est l'espèce-tout ce qui est bon à faire une subdivision de genre, est bon à faire un genre; il convient de lui donner un nom appelé générique." p. vii. Hence every section and sub-section proposed amongst the Haustellated Hemiptera is herc raised to the rank of a genus-the Linnæan genus Cimex being cut up into 340 genera, upwards of 150 of which are now first proposed and named. The authors strongly insist that such a plan is absolutely logical, but in one respect the result of their arrangement is anytling but uniform; for instance, the genera of Pentatomides or Reduviides are distinguished from each other by characters of very slight importance, whereas A canthia, Hebrus, Hydrometra or Leptopus, notwithstanding the weight of their cliaracters, are only regarded as groups of equal value, that (is as genera, with these trivial groups. To unaintain a series of gradational characters, and yet to deny it virtually by calling all these groups by one name, is not logical ; thus Hydrometra, Acanthia or Hebrus, ouglit not, on this prineiple, to be called genera, but tribes, 
and Leptopus a sub-tribe. I have elsewhere* so filly entered on the propriety of adopting subgeneric names, that I shall not here do more than thus refer to the plan.

This multiplicity of new genera has led to another inconvenience. In order to avoid the possibility of using generic names formed from the Greek, which had been used before, the authors have had recourse to the Arabic, Chinese, Sanscrit, and Hebrew, (in opposition to the Linnæan and Fabrician canons; $\dagger$ ) the characters of all which languages are scattered over the pages, it being the plan of the anthors to give the derivations of each generic name adopted thronghout the work: occasionally when this has not been given by the original proposer of a name, they have failed in attaching the correct signification to it. Thus my genus Deroploa, distinguished by having its prothorax armed with two very thick spines (from the Greek $\Delta \epsilon \rho \eta$ and ${ }^{\circ} \pi \lambda \alpha$ ), is given with the derivation of the "neck" and "navigation," with a remark on its want of sense. So my name Metapodius, applied to a genus in which the metathoracic feet are very large, is said to be derived from the toothed front of the head (Metopodus), and it is added, that I have written "Metapodius par erreur, sans doute," whilst the names which I have given to the genera established by me allied to Derbe, (and to which, following the plan set by Fabricius of giving to various Homopterous genera the names of towns in the Holy Land, e.g. Derbe $\neq$ and Lystra, I had applied the names of Zeugma, Patara, Phenice, \&c.), are set down by our authors as "noms de fantaisie, formés sans règles grammaticales et purement au hasard."

In the last place, it is to be regretted that the various contributors to this series have not adopted a uniform plan in treating the species; whilst some, as Messrs. Edwards and Boisduval, have made their works a complete descriptive "species insectorum," others have given only those species which they happen to have seen in nature, either entirely omitting all notice of the genera and species described by others, or giving only references to them.

* Ent. Text Book, p. 59. Trans. Ent. Soc. iii. p. 29.

+ " Nomina gencrica qux ex graca vel latina lingua radicem non labent rejicienda sunt." -Linn. Pbil. Bot., p. 163.

"Nomina barhara qux quidam in Entomologia in novissimis temporibas introduxerunt omnino rejicienda, quem nullo modo intelligantur et difficile pronuncientur."-Fabr. Phil. Ent., p. 109.

‡ Tho authors statc that the etymology of the name Derbe is "inconnue." Had they been arrare of its true signification, tbcy would hare possessed the clue to the etymology of my generic names allicd to that genus. 
The omissions in this respect are in many instances very important. As it is, however, we have here collected together a vast mass of materials, which if it be not absolutely a general "species insectorum," comes much nearer to it than could perhaps have been produced in any other country, and which, with the assistance of the numerous Bibliographical Notices collected together in Dr. Erichson's Annual Summaries, may ultimately be made the groundwork of a complete worlk.

Orservations Reratives aux Sexes des Coléoptères Hydoocantiares en général et spécialement de l'Hydaticus verrucifer. Par M. le Comte M a Nererhers. (Extracted from the Acta Societatis Scientiarum Fenuicæ. Tom. 1. fasc. ii. Helsing* forsiæ, 18 1 . 4to.)

The spirit of association for the diffusion of science is here muirfested in the publication of the first parts of the Transactions of the Society of Sciences of Finland; and to which several papers have been contributed by the Count Mannerheim, one of the first of modern entomological authors. In the memoir, of which the title is given above, he has published a series of observations on the peculiar characters which distinguish certain individuals amongst the predaceous water-beetlcs (family Dyticida), which have long perplexed entomologists. These specimens amongst the Dytici, while they possess the simple tarsi of the females, have the smooth elytra of the males. These were first described as varieties of the males with simple tarsi, by Gyllenlal. By Ahrens and Kunze, as well as subsequently by Gyllenhal, they were considered as distinct spccies, in which both sexes had smooth elytra; and no less than four new specics were thus established in the genus Dyticus. This opinion has been adopted by -many subsequent entomologists, and in our own country the genus Leionotus has been formed for the reception of these supposed species with smooth-backed females. Other opinions have, however, been entertained respecting the nature of these individuals which have not been noticed by Count Mannerheim, but whicli will be found detailed in my'Mod. Class of Insects (vol. i. p. 105). The opinion of Dr. Erichson, that they are varieties of the femalcs of species in which that sex bas ordinarily the elytra sulcated.* is adopted by Count Mannerheim. Analogous, but less striking, variations also occur in the females of Cybister

* Dr. Erichson's 2nd group in the genus, proposed in the genera Dyticeorum, in which the females have elytra similar to those of the males (D. circumflexus), is disploved by the dis. covery of sulcated females, which form the species D. perplexus Dej. Such specimeus, however, occur but very rarely in this species, Kaf. M. Br. 1. 147 . 
Roselii and C. lavigatus, the variety of the female of the former being known under the name of Dyticus dispar, Rossi. In Acilius, as restricted by Eschscholtz, A. semisuleatus and A. abbreviatus are female varieties of the same species. In Thermonectus the females also vary in the smooth or punctate base of the elytra. The same remark also applies to various species of Hydaticus; and Dr. Erichson also considers that there are also dissimilar females in certain species of Hydroportus.

The Hydaticus verrucifer, Sallb., however, is even more interesting in this respect than any of the before-mentioned species, and has formed thechief subject of Count Mannerheim's memoir. 'This species was formed by Aubé into a separate section of the genus, witl the character of simple tarsi in both sexes, whilst Dr. Erichson regards it as the abnormal female of Hydaticis zonatus. Having received a number of living specimens of this supposed species, Count M. observed that some of those with smooth elytra possessed dilated tarsi, and others simple tarsi. The former, as well as some of the latter, of these individuals would therefore belong to $\mathrm{H}$. zonatus, and the remainder of the latter would be males of the verrucifer.' But, in respect to the punctuation and structure of the thorax and elytra, M. Mannerheim observed a complete gradation from the rugose verrucifer to the smooth zonatus; whilst a dissection of numerous individuals proved that every specimen with dilated anterior tarsi were males, and that every specinen with simple tarsi were females; and amongst these latter were found the specimens with simple tarsi and radiated impressions on the thorax, which M. Aubé regarded as the males of verrucifer. Count Mannerheim, in conclusion, endeavours to trace the analogy which in this respect exists between these water-beetles and other species of insects in which we find a marked diversity of structure; instancing, first, the neuters of social Hymenoptera; and, secondly, the variations in the size of the horns of the liead and thorax and dilatation of the hind legs in certain beetles. But in neither of these tribes does the analogy hold good, because, first, the neuter Hymenoptera are but imperfect females, whereas, the smooth-backed female Dytici have been repeatedly captured in copulâ with the dilated-footed males; and, secondly, because, it is the males only amongst the beetles which offer such variations which, moreover, are gradual, whereas, no intermediate gradation has been observed between the sinootl and sulcated female Dytici. 
VERSUCH, einer systematischen Bestimmung und Auseinandersetzung der Gattungen und arten der Crenrl. eincr Insectenfamilie, aus der Ordnung der Coleoptercn, von Dr. F. Klug. From the Transactions of the Academy of Berlin, 1842, Ato. $142 \mathrm{pp}$. 2 pl. containing 32 col. fig.

TuE labour's of Drs. Klug and Erichson are by degrees making us fully acquainted witl the entomological riches of the National Museum of Prussia, over which they preside with so much honour to themselves and benefit to the scientific world.

The present Memoir is devoted to the Cleridæ, and surprises us at the vast number of species of which it furnishes descriptions. Dr. Klug has adopted only 12 genera in the family, regarding most of the numerous groups of Laporte, Spinola, Clievrolat, Newman, \&c., as sections. The genera adopted, and the number of species in each respectively contained in the Berlin Cabinct, aro as follows:Cylidrus, 5 sp.; 'Tillus, 28 sp.; Priocera, 4 sp.; Clerus, 70 sp.; Ptychopterus Kl., (n.g.) 1 sp. from Caffraria; Axina, 1 sp.; Opilus, 19 species; Exymanthis Kl., (u.g.) I sp. fronı Caffraria; Trichodes, 20 sp.; Corynetes, 19 sp.; Cylistus, (n.g.) I n. sp. from Caffraria; and Enoplium, 50 sp.-CTotal, 219 species, of which more than half are new. A supplement contains short dcscriptions of 59 other species not seen by the author. The following is a slort summary, which $T$ have taken some pains to draw up, with reference to the geographical distribution of the species. Of the 219 species described from the Berlin collection-

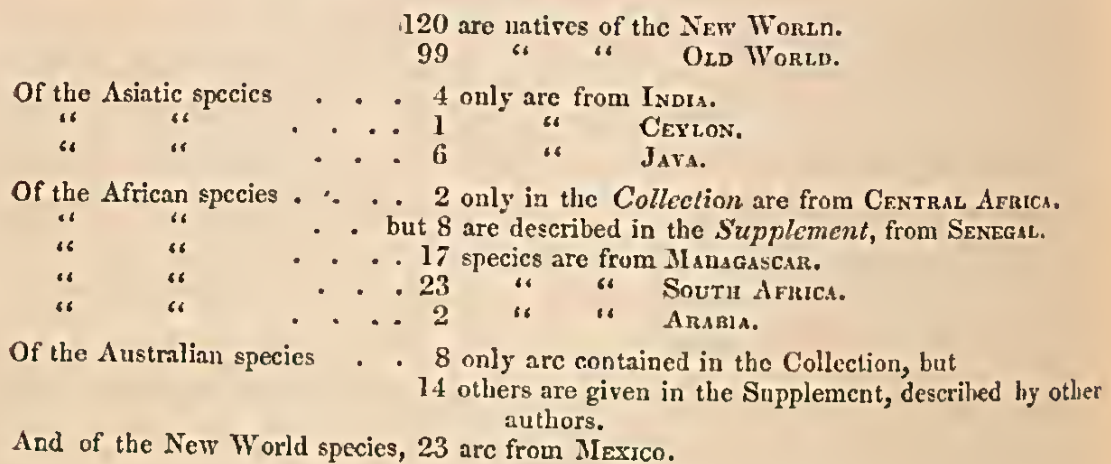





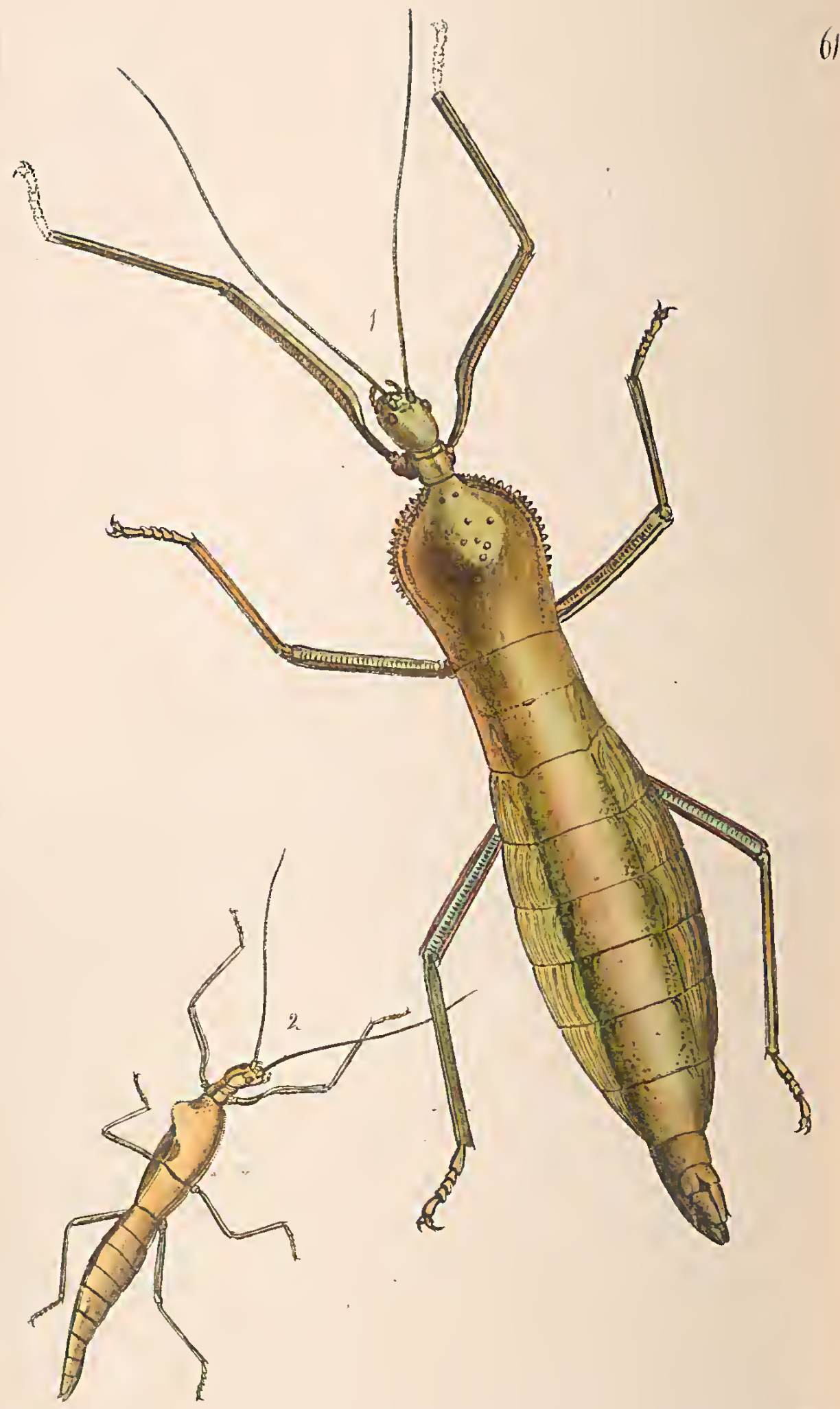

(6) 


\section{PLATE LXI.}

ILLUSTRATIONS OF TWO SPECIES OF SPECTRE INSECTS.

IN the first volume of this work (plate 8) a representation was given of an insect from my own collection, belonging to the family Phasmidre, to which, upon the information of Dr. Burmeister, the name of Phasma (Craspedonia) gibbosa* was given, with a reference to his Handb. d. Ent. 2, 575, and with the habitat of "Brasilia, teste Burmeistero."

"It appears, however, from Dr. Erichson's Bericht for 1841, p. 72, that the insect figured by me is distinct from Burmeister's D. gibbosa, described from the Berlin Cabinet, and that, instead of being Brazilian, it is an African species. Dr. Erichson doubts the correctness of my description of the rudimental wing-covers and wings, as well as of the four-jointed anterior tarsi. My specimen is, however, fortunately, perfect (except in wanting a few of the terminal joints of one of the antenna), and possesses only four joints to each of the fore-tarsi, and the rudimental tegmina are perfectly distinct, and entirely free, and eapable of being elevated by introducing a pin beneath them, being about one-sixth part of an inch long; the winglet, although very much more minute, has the outer edge free.

It becomes, therefore, necessary to apply a new specific name to the insect figured in Vol. I., and for which, in allusion to the regularly-curved margins of the abdominal segments, the name of

DIAPHERODES (CRASPEDONIA) UNDULATA, $W$. , (Vol. I., Pl. viii.)

may be applied. It seems to approach the Cyphocrana? punctipes, Serville (Orthopt. p. 239), which is also a native of the coast of Africa, but differs in the spines of the thorax and feet, the under surface of the thoracic segments in my insect being perfectly smooth and free from spines.

DIAPHERODES (CRANIDIUII) SERRICOLLIS, Westw. (Plate 61, fig. 1.)

D. viridis, glabra, capite integro gibbo ; mesothoracis dorso et lateribus mesosternoque longitudinaliter obtuse spin osis; abdomine dilatato, dilatatione tenui, continua, striata, pedibus omnibus gracilibus inermibus, tcgminibus alisque nullis.

앙 tong. corp. nnc. $4 \frac{3}{4}$. Latit. abdominis unc. 1 .

Habitat —? In Mus. Hope.

* "D. gibbosa : capite integro gibbo; thoracis margine mesonotique dorso obtuse spinoso ; ( $\hat{\sigma} ? ;)$ q alis nullis abdomine dilatato distinctè marginato. Long. corp. $5^{\prime \prime} 6^{\prime \prime \prime}$.

Brasilia, 2 우 in Mus. reg. Berol."-Burm. 1. c.

No. XVI.-1st NOVEMBER, 1843. 
The large, oval, posteriorly truncate, and very gibboso mesonotum measures $\frac{5}{6}$ of an inch in length, and has the sides armed with a row of obtuse spines, which become obliterated towards the hind part; within this row there are also a few much smaller spines, forming a parallel series, towards the front part; the centre of the elevated part is armed with about a dozen raised tubercles, and there are also two smaller ones on the disc towards the fore margin; the underside of the mesothorax is armed with a double row of these tubercles; the metathorax is nearly square, of equal breadth with the hind part of the mesothorax; and the five basal segments of the abdomen are dilated into an elongate oval form, the middle portion of each being convex, but the sides forming a very thin margin, along which r'un five slender, longitudinal ribs, which I presume to be veins. The seventh segment beneath is formed into a boatshaped appendage, extending beyond the ninth dorsal plate, longitudinally carinated, and divided by a slit into two parts, for a considerable distance along its apical half. The ninth dorsal segment is furnislied at each side with a small conical appendage, and within the boat-shaped plate are enclosed two long arid slender, flattened setro, extending as far as the tip of the keel. The feet are all quito simple, and destitute of tceth or spines, and are comparatively slender. The general colour is pale green, but the head and pro- and meso-thorax, as well as the feet and anal apparatus, are changed to a pale brown.

Mr. Hope's unique specimen of this insect is unfortunately destitute of any indication of the habitat of the species. It appears to be closely allied to Dr. Burmeister's D. gibbosa, above-mentioned, but the marginal spines are confined to the mesothorax, not extending along the entire thorax, as described by Burmeister.

\section{DIAPHERODES (CRANIDIUMI) PUMILIO. (Plate 61, fig. 2.)}

D. lutcscens (viridis?) capite incrmi mesothoracis lateribus sensim dilatatis vix scrrulatis, disco in carinam mediam valde clevato; abdomine elongato vix dilatato supra carinato, apice acuminato ; pedibus gracilibus simplicibus, alis nullis; 오.

Long. corp. unc. 2. Habitat in Africa tropicnli? In Mus. Bristol Philos. Institution.

The singular, almost semicircularly elevated earina along the middle of the mesonotum, at once distinguishes this insect from all other Phasmidx. It appears to be congeneric with the species last above described, althougl destitute of any lateral dilatation. From the development of the sexual apparatus, which is nearly similar to that of $\mathrm{D}$. serricollis, I consider the specimen not to be in an immature state. 



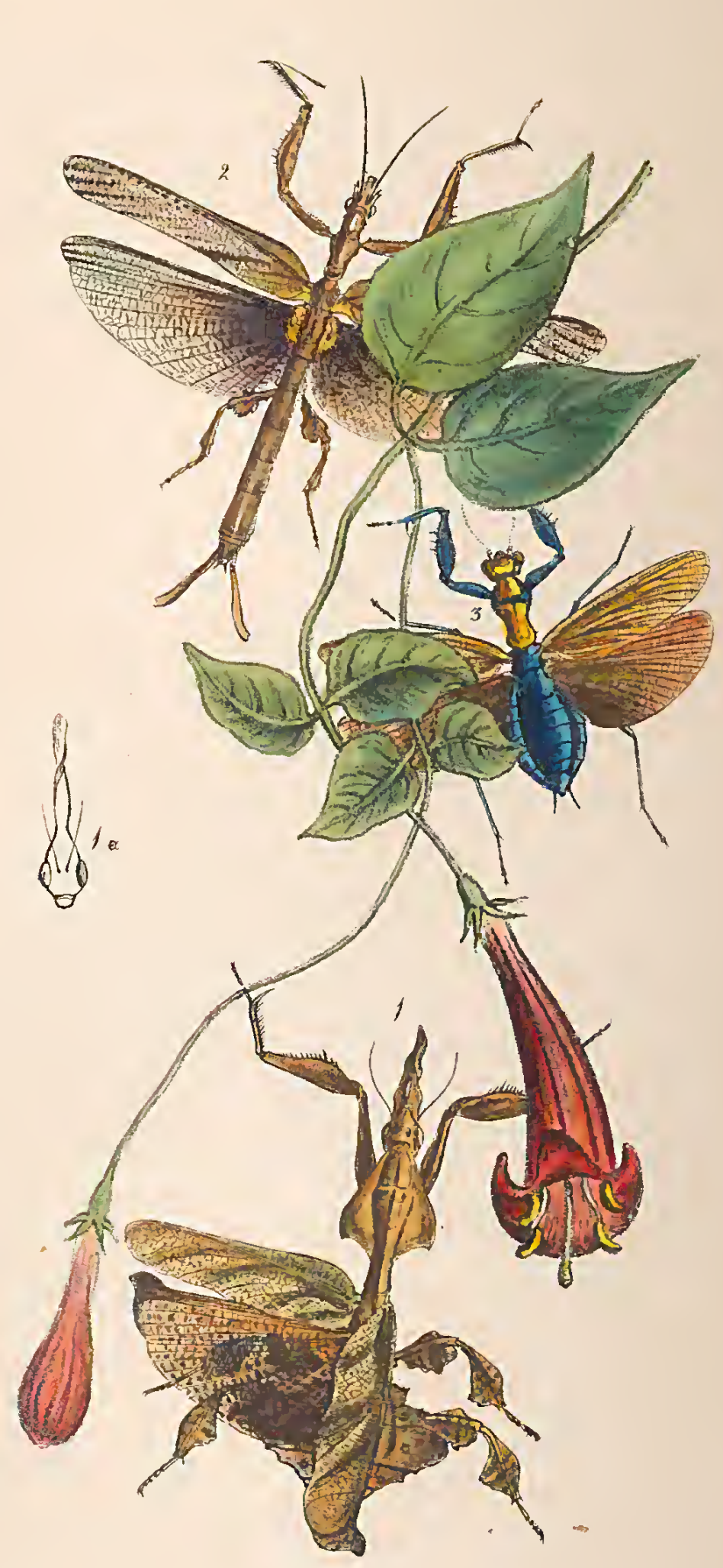

62 


\section{PLATE LXII. \\ DESCRIPTIONS OF SONE NEW SPECIES OF SOOTHSAYERS.

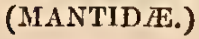

\section{PHYLLOCRANIA INSIGNIS, Westw. (Plate 62, fig. 1.)}

$P$. lutco-fusca, tegminibus olivaceo-fuscis, basi, vittaque obliqua media albidis, alarum angulo apicali producto, hoc areaque anali fuscis reliqua parte alarum fulvescentc fusco irrorata, foliolis prothoracis et pcdum posticorum albido et olivaceo variis.

Long. corp. (cornu capitis incluso) unc. $2 \frac{1}{3}$.

Habitat in Sierra Leone. In Mus. Britt. et D. Hope.

This insect appears to be specifically distinct from $\mathrm{Ph}$. paradoxa, of Burmeister*; it agrees, however, with it in its remarkable structural peculiarities, namely, the singular, elongated, narrow, leaf-like appendage of the head, the dilated sides of the prothorax, and the leaflets of the four hind femora and tibiæ. Mantis Diana, of Stoll (fig. 100), and the Empusa, agree with Phyllocrania in the produced head, but the latter have pectinated antennæ in the males, whereas all the specimens of the species above described, which I have hithcrto seen (one belonging to the Rev. F. W. Hope, and two discoloured ones in the British Museum collection), possess very slender, simple antennæ. Of these specimens two agree in having a shorter appendage to the head, one of which is represented in my plate, whereas the other has the head produced into a much longer, slenderer, and morc curved horn (fig. 1 a). This last, I apprehend, is the male, and the other two females. In all other external characters, however, they agree together. Mantis (Blepharis) Kuhlii of De Haan (Bijdragen, \&c., plate 18, fig. 3), seems in general form, dilated abdomen, and foliated hind femora, to approach nearer to Phyllociania than to Blepharis mendica.

MANTis METALlicA, Westw. (Plate 62, fig. 3.)

II. chalybea, nitida, capitis plaga verticali, et pronoto antice et postice flavis, tegminibus fulvis venis viridibus, alis ad angulum analem late fuscis.

Long. corp. lin. 14. Expans, tegmin. unc. 2.

Inhabits Sylhet iu tho East Indies. In the collection of the Rev. F. W. Hope.

With the exception of Metallyticus splendidust, and the present species, I am not acquainted with any metallic Mantideous insect. The body and legs are of a bright steel blue, except the middle of the disc of the head, a rounded patch near the fore-margin of the pronotum, and a larger posterior spot, which are of a rich yellow

* Ph. fulvo-viridis, elytris macula basali rhombea, vittaque obliqua post medium pallide testaceis, roseo-micantibus; alis fusco tesselatis. Long. corp. 1'". Habitat apud Cap. Bon. Spei. Handb. d. Fut. Orthoptera, p. 549.

+ Westwood, in Zoolog. Journ., vol. v., p. 442 , pl. 22 , fig. I. I also figured a brilliant and rare variety of the same insect in the British Cyclopædia of Natural Hist., Orthopterous Insects, fig. med. dext.

Syn.-Mantis chalybea, Serville, H. n. Orth., p. 202. : 
colour, and the base of the first joint of the anterior tarsi, which is white. The prothorax is rather short, and dilated at the sides over the base of the fore-feet, as is also the hinder margin; the abdomen also has the sides dilated. The tegmina are destitute of the small horny patch, so conspicuous in some of the species of the genus; the hind wings are fulvous-brown, with the anal angle broadly brown, the veins in the latter part being yellow; the posterior femora and tibix being simple. The entire body beneath is also blue-black.

\section{STENOPHYLLA, Westw.}

Corpus elongatum valde angustum. Caput cornu porrecto apice truncatnm spinanuo subbifida utrinque ante oculos armatum. Oculi ovales. Antenna subgraciles. Prothorax vix meso- et meta-tlorace longior, supra insertionem pedum anticorum dilatatus. Abdomen longum gracile parallelum segmentis apiealibus brevissimis parum latioribus, ultimo supra conico, subtus in spinis duabus brevibus diraricatis desinente; cerci anales valde elongati (prothorace paullo longiores), compressi ad basin articulatis, apicibus parum emsrginatis. Pedes antici clongati, 4 postiei breres femoribus foliatis tibiisque extus folio rudimentali jnstructis. Tegmina et alre posticse perfecta angusta.

The singular head and tails of the insect represented in figure 2 at once distinguish it from every other insect in the present family. Elongated tails are indeed found especially in Tarachodes Perloides, a new insect, described by Dr. Burmeister, from the Cape of Good Hope; but the head and feet in that genus are quite unlike those of the present species, and the tails themselres are described by Burmeister as threads, " fFaurn," whereas they are flat and thin in the present insect, the basal portion alone being articulated. This divarication from the normal, small, conical, articulated form of these appendages is seen in but very few other species of the family, and in none to the extent here exhibited. The Toxodera denticulata of Serville, from Java ", has them broad and foliaceous, but comparatively short, and from this character M. Serville has assumed a relationship with the Plasmidx. The species figured in my first volume, pl. 41, under the name of Toxodera (Heterocheta) tenuipes, possesses similarly dilated, foliaceous appendages, as do also Vates Ashmolianust, TV., a native of the East Indies, of which the characters are given in a note below, and the Australian Mantis latistylus of Serville.

STENOPHYLLA CORNIGERA, Wesiw. (Plate 62, fig. 2.)

St. fusca, brnnneo varia, tegminibus basi pallide luteis striga obliqua fusca, costa venisque longitudinalibus fusco-guttatis; alis basi fuscis violaceo micantibns, venis transrersis, in dimidio basali alarum costaque fuscis.

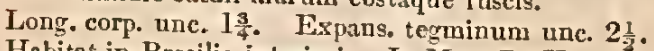

Habitat in Brasilia interiori. In Mus. D. Hope.

The plant represented in the plate is the elegant Brazilian Manettia cordifolia of Von Martius.

* Ann. Sac. Ent. de France, tom. vi., p. 25, pl. 2 : and Hist. n. Orth., p. 169, pl. 5.

$\uparrow$ VAtes Asurolraxus, Westr. (Annals of Nat. Hist., Dec. 1811), fuseas eapitis vertice 
c. 


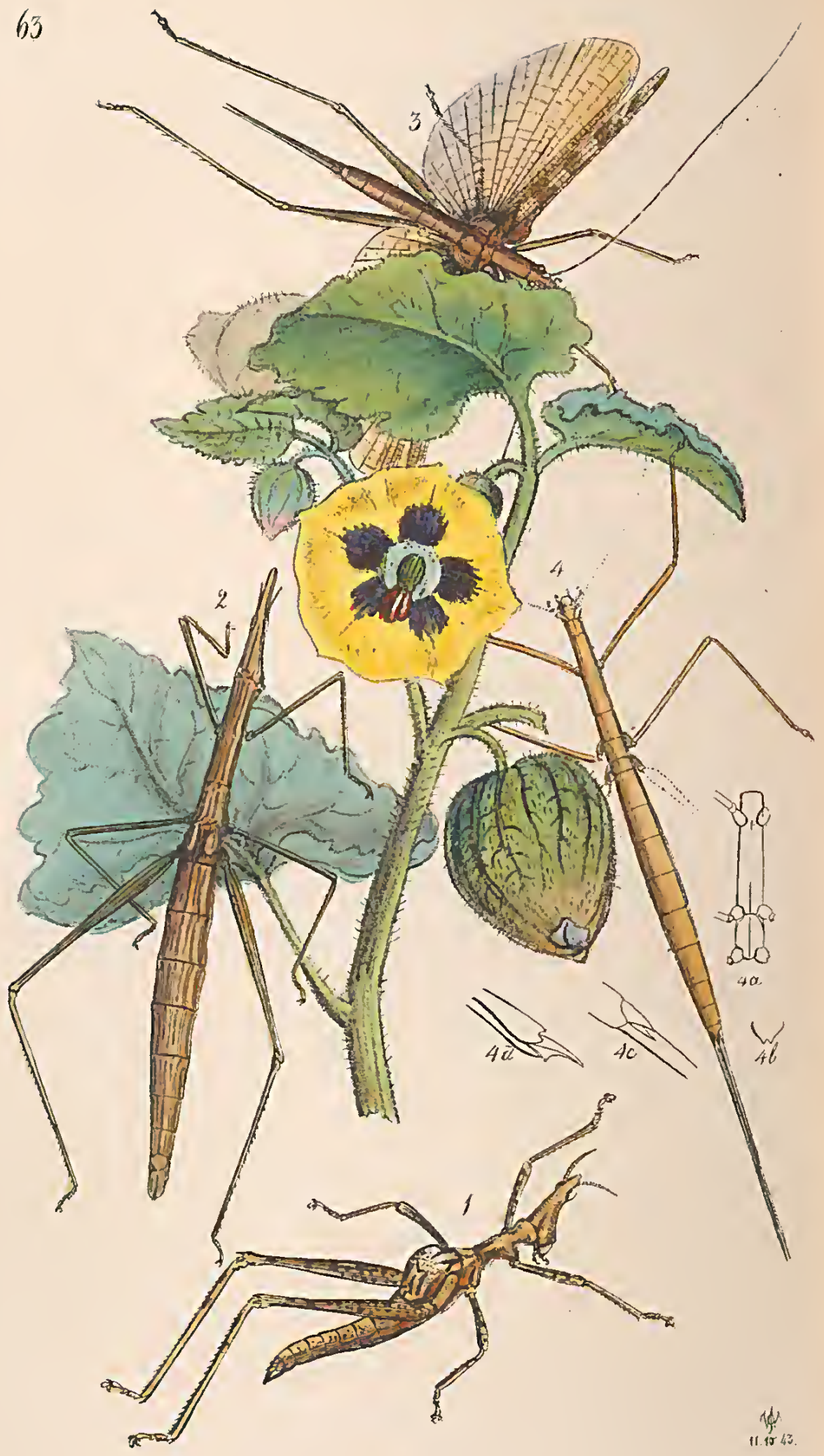


PLATE LXIII.

DESCRIPTIONS OF SOME ORTHOPTEROUS INSECTS BELONGING

TO THE SECTION SALTATORIA.

PROSCOPIA OCCIDENTALIS. Westw.

(Plate 63, fig. 1.)

P. fulra, nigro fuscoquc varia, rugoso-punctata, eapite antc oculos conico, prothoracc eapitis longitudine nargine antico dilatato, metathorace valdo tumide. Long. eorp. unc. Is. $\hat{\sigma}$, unc. 2. ㅇ.

Habitat. Valparaiso, Chili. In Mus. IIope, and Mus. Britt.

Tris curious species is more robust than the generality of the inseets of this singular genus. The head of the male has the sides rather eurved and rugose, but in the female they are straight, forming with the part in front of the eyes an clongated eone; in the latter sex it is more rugose than in the male. The antenna of both sexes arc 9-jointed * they are slightly thiekened in the middle, the tip being slenderest; they aro inserted in the underside of the head between the front part of the eyes. The prothorax is narrower than the head, its narrowest part being before the place of insertion of the fore-feet; it is transversely rugese, and has the hinder portion nearly quadrate. The meso- and meta-thorax are swollen inte a rounded hump, nuch broader than the rest of the body in the male, the abdomen in that sex being narrowed. The speeimens before me liave, however, been taken out of spirits, and are shrunk in tho base of the latter part, so that I eannot speak with eertainty on its form, er as to the shape of the meso-and meta-thorax in the female. The feet are eomparatively robust, and the ungues are very nuch dilated at the base, being furmished with an appendage almost as large as the pulvilli; the posterior femora are striated. I do not pereeive in this species the differenee in the number of the abdominal segments of the opposito sexes pointed out by $M$. Brulle; on the eontrary, in both I find the same typieal structure, namely, seven basal seginents of equal size, both on the dorsal and ventral surface, followed by two very short ares, eut off obliquely at tho sides on the dorsal surfaee, representing the 8th and 9 th dorsal segments, whilst the 8 th ventral are is dilated into

rotundato antennis gracillimis, prothorace longissimo (long. unc. 13) angusto lateribus serrulatis; tegminibus et alis abdomen haud tegcutibus, illis pallidis grisco ct fuseo parnm varis nubila fusca versns bisin, rcnisque nigro strigatis; alis hyalinis, costa maculisque nubilaquo rersus basin brunncis; ecrcis analibus latis tolineeis, pcdibns 4 postieis brevibus femoribus fere ad apicem 3.foliatis tibiisquo anto incdium supra parum foliatis. Tong. corp. unc, $4 \frac{1}{3}$. Habitat in India orientali. In Mus. Ashmol. Oxon, et D. Hope.

* Drs. Klug and Burmeister deseribed the antennæ of the males of Proscopia as 6-, and those of the females as 7-jointed, M. Brullé describes the antennae of both scxes as 8-jointed. IIist. Nat, d. Ins, Orth, ct Hew, p. 2 I2, 
a conical plate hollowed out above, and more elongated and entire in the male, whilst it is longitudinally divided in the female; the 9 th ventral segment in both sexes being represented by the two small horny triangular plates, behind or beneath the small conical appendage common to Orthopterous insects. It is in the variation of form of these several pieces that the sexes are distinguished.* The general colour of the insect is fulvous-yellow, considerably spotted and marked with black and dark brown, especially on the thighs and back of the thoracic segments.

No species of this genus has hitherto been described as inhabiting any other part of South America than Brazil. The present species, therefore, presents us with an instance of a wider geographical range, being a native of the western portion of South America, whence it was brought, I believe, by Mr. Cuming: it is from this circumstance that I have given to it the specific name employed above.

Proscopia is one of those singular forms which exhibit a great resemblance to the species of a family different from that to which they in reality belong. Thus, we have here the long slender cylindric body of Bacteria amongst the Phasmidle, as well as their apterous condition. M. Brulle also mentions two other characters possessed by these insects analogous to those of the Phasmidx, namely, the plate terminating the abdomen of the males, and the compressed and angulated palpi. They appear to represent the old world genus Truxalis, in South America, and are evidently brought into relation witl the more typical Locusts by that genus, and especially by the genus Mastaxt, (illustrated in the first volume of this work, pl. 26), and by the Astroma chloropterum of Charpentier+, a most interesting insect, also from Chili, (allied to Proscopia, and also to Tetrix Latr.,) which is described as destitute of all traces of the wing-covers, but having two small greenish wings arising from the first segment of the body (after the prothoras).

* I presume that M. Brulle's first ventral arc in tbe males is the hind part of the meta. stcrnum, separated from the anterior part by an impressed line, which, however, exists less distinctly in the females; and that his 9 th ventral segment in tbe male is the undivided conical cighth ventral arc.

+ Germar's Zeitscb. f. d. Ent. 3, 305.

\# I take this opportunity of describing a new speries of Mastax, recently forwarded to me from Assm, by Mr. Robinson, by way of supplement to the Memoir on this genus in the first volume of this work.

Mastax afFinis. W. Fusea, facie et lateribus fulvescentibus, capite erecto rertice ad apicem truncato subbifid o, prothorace carina elevata acu ta, abdomine $\hat{o}$ ad apicem valde inflato, tegminibus fuscis guttis duabu hyalinis, alis fulvis margine tenui fusco. M. guttatio valde affinis sed multo major. Long. corp. lin. 10. Expans. tegmin. lin. 22.

Habitat. Assam, Iud. Or. In Mus. nostr. amicissimc comnunic. D.Robinsoy. 
The species of the genus Proscopia are arranged by Dr. Burmeister* in the following manner :-

I. Those with the eyes placed near the middle of the sides of the head, the front part of whicb is obtuse, with the sides parallel, or diverging and quadrangular.

A. Those with the front part of the head dilated at the end, 1. Pr. spinosa, Kl.; and 2. Pr. granulata, líl.

B. Those with the front of the hear of equal breadth throughout.

$a$. The extremity being as hroad as the space between the eres.

a. Prothorax granulose. 3. Pr. radula, Kl. 4. Pr. hospida, Kl.

B Prothorax with impressed punctures. 5. Pr. punctata, Kil. 6. Pr. brevicornis, $\mathrm{Kl}$.

b. Extremity of the head evidently narromer than the space between the eyes. 7. Pr. scalura, Kl., and P'r.gigantea, Kl.

1I. Those with the eyes placed near tho tip of the head, which is acuminated.

A. Extremity of the head as loug as, or longer than, balf the antenna. 9. Pr. striata, Kl. 10. Pr. acuminata, Kl. 11. Pr. ruficornis, lil. 12. Pr. rostrata, Kl.

B. Extremity of the lead very small, much shorter than the half of the antennæ. 13. Pr. Orevirostris, Kl. 14. Pr. Ophiopsis, Kl. 15. Pr. oculata, Kl.

M. Serville $†$ divides the genus in the following manner:-

1. Head elovated into a kind of vertical pyramid, \&ce. (Proscoprs proper.)

A. Eyes of modento size. oblong. Pr. scabra, Kl., and Pr. granulata, Kl.

B. Eyes large, and ncarly rounded. Pr. rostrata, líl.

2. Head not clevated into a vertical pyramid, hut horizontally prolonged in front in the same line as the hody, \&e. (Cepaloceru.) Pr. (Ceph.) Sica, Scrv. n. sp. from the sonthern part of Campos-Geraes, in Brazil; described from the Collection of tho Jardin des Plantes, where 1 examined and sketched tlo typical specimen described by M. Serville, and find it to be very closely allied to the inseet next to be described.

PRoscopia (CEPHALOCEMA) SUBAPTERA, Westw. (Plate 63, fig. 2.) (Long. lin. 7.)

P. fusco.brunnea, capite horizontali sensim ad apicem attenuato, antennis vix dimidio rostri longioribus, thorace et abdonine longitudinalitcr striatis, prothorace, antice ct postice bispinosis; mesothoraco spinis duabus paullo majoribus armato tegminibusque duobus liberis minutis instructo, alis duabus minimis liberis nigro-metallieis nitidis sub tegmina reconditis, abdonine supra depresso. 우 Loug. corp, unc. $3 \frac{1}{4}$.

Habitat. in Brasilia. Mus. nostr.

Obs.-Individium alterum 우 possldeo $2 \frac{1}{2}$ lin. Iongitndine, statura paullo angustiori rostro longiori (pro magnitudine iusceti) coloreque cincroo: spinis thoracis ut ct tegminibus et alis cum precedonti rero congruens, vix species distincta.

The insect represented in figure 4 in this plate is one of the most interesting Orthopterous insects hitherto discovered; and it is greatly to be regretted that the very mutilated state of the unique female specimen in the British Museum Collection prevents me from being able to give its whole character. Indeed, it is not surprising that from this circumstance it should have been arranged amongst the Phasmidæ in that collection, since its general appearance certainly bears a much closer resemblance to some of the wingless Phasmidæ than to one of the saltatorial Orthoptera. A slight examination, however, convinced me that, from the structure of the tarsi, and the relative size of the thoracic segments, the insect 
belongs to the family of grasshoppers with long-antennx (Gryllide, Leach), although differing from all the known species of that family in several particulars, more especially in the entire want of the curious operculum near the base of the anterior tibiæ, and the large compressed form of the basal joint of the antenna, which is all that remains of those organs in the specimen before us. From its analogical relations, it may be named-

PHASMOdes Ranatriformis, West. (Plate 63, fig. 4.)

Char. Gen. 9 . Corpus valde elongatum depressum paralleluu abdomine sensim in medio paullo latiori. Caput horizoutale, elspeo habroque magnis discretis. Palpi elongati. Labium e lobis duobus membranaceis spinisquo duabus intermediis formatum. Antenno articulo basali longo compresso. Prothorax elongatus subdepressus subtus inermis: meso- et meta-thorax breves subtus otian incrmes linca longitudina mediana impressa (fig. $4 a$ ). Abdomen thorace duplo longins ad apicem sensim attenuatum e segmeutis noren dis. tinctis formatum. Oviductus fero abdominis longitudine reeta attenuata, o valvulis duobus corneis constans, singulo valvulo e duabus partibus formato (fig, $4 b$ apex segmenti noni subtus visus: fig. $4 c$, apex scgmenti noni abdominis lateraliter visus cum squama couica dorsali etyloque latcrali et basi oviductus : fig. 4 , apex valvuli e duabus partibus constans, supcra nd apiceru cunrginata, infera aeuta et subtus tuberculo instructa). Pedes 4 antici longitudine sequales, graciles, tibix anticæ operculo nullo instructæ. Tarsi 4-articulati pilosi articulo penultimo cordato. Teguina nulla. Als nulla. Mas lateto Char. Spec. P. viridis, lævis lateribus corporis linea brunnea notatis, tibiis anticis versus basin macula parva fusea,

Long. corp. unc. 2i. Oviductus, unc. $1 \frac{1}{4}$.

Habitat. King George's Sound, Nov. Holl. In Mrus. Brit.

The nearest approach to the last-described insect amongst the species of the family Gryllide, Leach (Locustaires Serville,) is mado by

\section{a Prochilus Australis of Brullé,*}

described more in detail by M. Serville. As no figure of this insect has hitherto appeared, + and as the male alone has been described, I have represented the female in plate 63 , fig. 3 , and which agrees in general character with the male, which has the abdomen truncate at the tip. I have possessed this insect many years; and Mr. Hope also possesses three specimens-one from the Haworthian Collection. Messrs. Brullé and Serville do not speak of the red base of the hind wings; and the latter states that the head is longer than the prothorax, and that the stridulant organ of the males is trinsparent, which do not agree with the specimens before me; although they correspond in every other respect with the description given by $M$. Serville.

The plant represented in the plate is Physalis edulis, a native of Peru and Chili, but cultivated at the Cape of Good Hope, and in the English Settlements in New South Wales, where it is known under the name of the Cape Gooseberry.

* Hist. Nat. des Ins., Orthopt. et Hemipt., p. 135.

t Hist. Nat. Orthont., p. 384.

* Brullé and Serville refer to al figure of this insect, "Plate 11, fig. 1, Mâle," but no such has hitherto been publikhed. 

64

16. 0
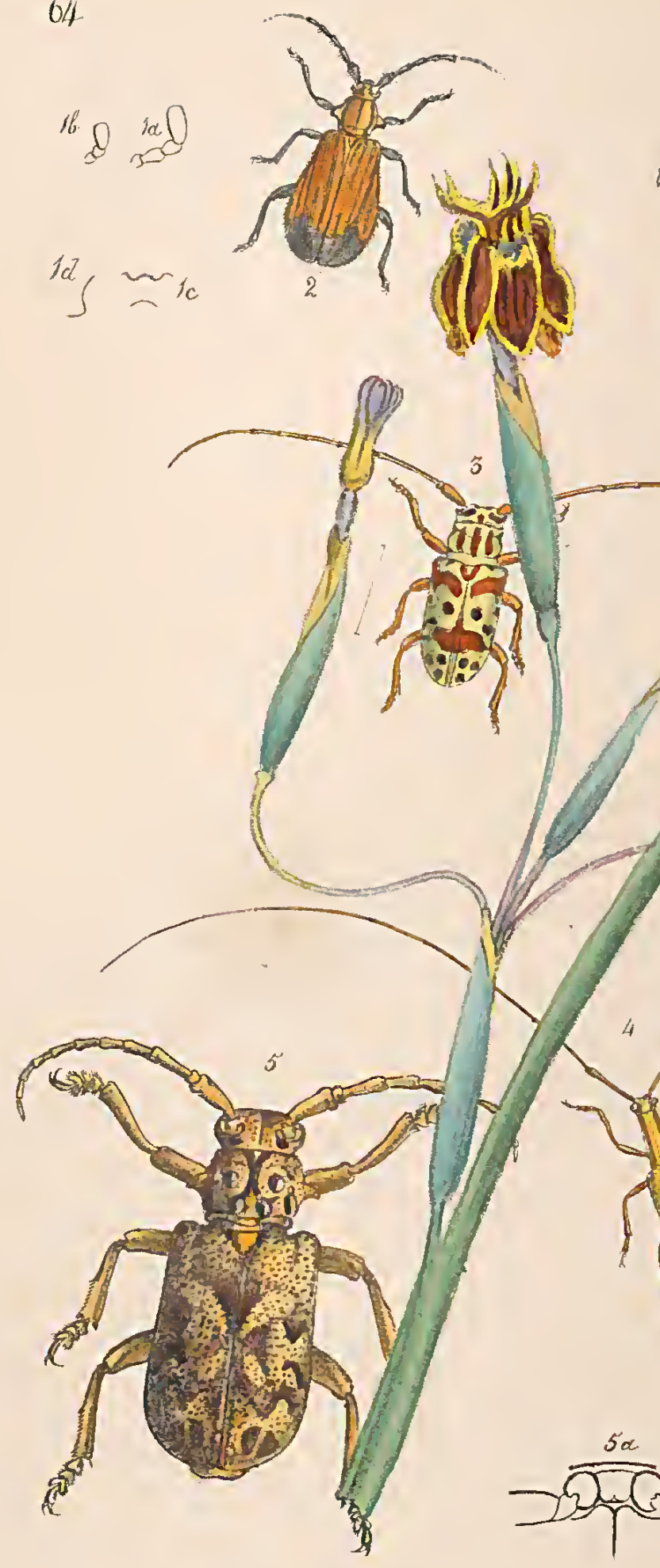


\section{PLATE LXIV. \\ DESCRIPTIONS OF SOME AFRICAN LONGICORN BEETLES.}

\section{PARISTEMIA. Westev.}

Genus novum e familia Cerambycidarum, gcneribus Lophonocero of Pteracantho Newm.* affine. Capıt parrum facio obliqua. Oculi valde emarginati. Labrum transversum eiliatum. Mandibule parre. Maxilla lobo apicali denso at bre viter penicillato. Labium ad apicem emarginatum. Antenna breves (in femina vix ad medium elytrorum extensa), erasse, articulis I et 3 longitudinc snbequalibus, rcliquis parum brevioribus. Prothorax eapite multo latior latcribus utrinque oblique porrectis $5 \mathrm{el}$ in spinam latam productis, angulis posticis valde emarginatis; disco in medio elevato-carinato. Elytra ad basin vix prothorace latiora, sensim rotundato-dilatata, apicibus simplicibus, disco longitudinaliter costata. Pedes breves subrequales. Species Afric tropiealis incolæ.

Species I.-Paristema Platyptra. (Plate 64, fig. 1).

P. nigra scricen prothorace rufo utrinque striga nigra e capite ad angulos posticos; elytris pone medium fascia latissima postice angulata et fere ad apicen extensa rufa; abdomine obscure rufo.

Sy:- - Paristemia platyptera, Westw. in Ann. Nat. Histo Oetober 1841. Long. eorp. lin. 121. Lat. elytrorum, lin. $5 \frac{1}{2}$.

Habitat in Africa tropicali. In Mus, nostr. Communic. D. Raddon. (Fig. 1 a. maxillary palpus; fig $: 1 \mathrm{~b}$. labial palpus; fig. 1 c. cxtremity of pro \& meso-sterna; fig. $1 d$. mesosternum, seen siderays.)

Species II.-Paristearia Apiealis, Westw. (Plate 64, fig. 2).

P. nigra exicea, capite linea media fulva, prothorace fulvo linea tenui media alterisque duabus lateralibus scutelloque nigris; elytris ad apicem nigris plaga antiee in angulum acutum vcrsus basin cxtensa, corpore subtus nigro, prosterno et mesosterni parte elevata fulvis.

Long. corp. lin. $9 \frac{1}{2}$. Lat. elytrorum, lin. $4 \frac{1}{2}$.

Habitat in Africa tropicali. In MIus. D. Turner.

Ols.-The antenne arc unfortunately broken off at the 7 th joint; they are, however, cridently longer tban in tho former species, which is therefore to be regarded as a female, and this as a male.

\section{SAPERDA CARISSINIA, Westu. (Plate 64, fig. 3).}

Annals of Nat. Hist. October 1811.

S. brevis opaca, supra viridi-lactea, pronoto rittis tribus longitudinalibus brunneo-fulvis, elytris fascia lata irregulari (in medio interrupta) ex humeris fere ad suturam dueta maculaque magna communi discoidali brunneo-fulvis; his etian guttis 10 nigris rotundatis ornatis.

Long. corp. lin. 5.

Habitat in Africa tropicali. In MIus. D. Raddon, Parry, Hopc, \&c.

\section{NEMOTRAGUS. Klug.}

I am not aware whether any characters have hitherto been published by Dr. KJug, of the genus instituted for the reception of the interesting insect represented in fig. 4. It is to the kindness of that distinguished entomologist that I am indebted for my specimen, which I received from liim in 1835 , since which period a considerable number of individuals have been obtained by one of the London dealer's in objects of natural listory. In this uncertainty I shall merely notice that its greatly elongated form, large

* The undescribed genus Ptcroplatus of Dejean's Catalogue, composcd of tbreo Brazilian and Mexican specics, is evidently also closely allied to these insects. 
rounded eyes, having a very small emargination in front, elongated, slender, and simplo antennæ, unarmed prothorax, pointed tips of the elytra and simple nearly equal sized-legs, with curved tibiæ, seem to constitute its chief characters.

NEMOTRAGUS HELVOLUS. Klug. (Plate 64, fig.4).

N. brunneus punctatus, luteo squamosus, linea longitudinali laterali prothoracis humerisque nudis, antennis pedibusque brunneis.

Long. corp. lin. 13, long. antenn. unc. $2 \frac{1}{2}$.

Habitat in Africa meridionali. In Mus. nostr. \&sc.

\section{LAMIIA OBESA, Westw. (Plate 64, fig. 5.)}

L. albida luteo-squamosa, fulvo fuscoquc varia, prothorace tuberculis vittaque media utrinque furcata fuscis, lateribus utrinque spina brevi crassa armatis; elytris maculis duabus subovalibus obliquis ante medium pallidis alterisque duabus minoribus mediis fasciisque variis angulatis maculisque duabus subapicalibus fuscis ornatis, facic antennis pedibusque luteis.

Long. corp. une. $1 \frac{3}{1}$. Lat. clytr. unc.

Habitat in Africa meridiouali.

This is one of the fine species of insects contained in the collection recently brought to England by Mr. Burke, from the hilly country, lying between $25^{\circ}$ and $26^{\circ}$ S. lat., and $27^{\circ}$ and $28^{\circ} \mathrm{E}$. long., and which, by the kindness of the Earl of Derby has been distributed to the Zoological Society and the British Museum. I am indebted to Mr. Melly for the opportunity of figuring the species, he having sent it to me on its first arrival in this country.

The plant represented in this plate is the Iris viscarea of Thumberg, found in the sandy spots of Saldanha Bay, near the Cape of Good Hope. 


\title{
ENTOMOLOGICAL INTELLIGENCE, NOTICES OF NEW WORKS, \&c.
}

\author{
(No. XVI.)
}

\begin{abstract}
Catalog der Kafer-Samluig von Jacob Stura. Nuremburg, 1843. With 6 coloured copper-plates. 8 ro, 386 pages.
\end{abstract}

WE have here an imitation of the Catalogue of Dejean's Collection of Coleopterous insects, with, however, occasional references to figures and synonymes. There is, however, a vast difference in the amount of species of the two collections, and consequently in the comparative usefulness of the two catalogues. Dejean's last edition contained considerably more than 20,000 species, whereas Sturm gives but 13,266. In many of the more interesting groups, the poverty of the latter list is very striking: thus, there is only 1 specics of Oxycheila, 1 Dromica, 2 Therates, 1 Casnonia, 4 Panagæi, 2 Rhipiceræ, 1 Callirhipis, 3 Goliathi (micans, japonicus, and Höpfneri), 2 Paussi. The catalogue is, as may be easily supposed, strongest in European and Brazilian specics. An appendix contains descriptions and figures (beautifully drawn, engraved, and coloured) of the following insects :-Three new Brazilian species of Lia (a genus allied to Lcbia); Axinidium africanum, St., a new genus, refcried to the Scaritidx, but having more of the habit of Stomis and Miscodera, with long toothless mandibles, long slender maxillæ, with tho hook not articulated (judging from the figure, for the description is silent as to this character), naxillary palpi strongly securiform, labial palpi slender and filiform, mentum conically produced in the centre, fore tibiæ not externally dentated (but with the deep notch and spur on the inside); the species is 4 lines long, black, smooth, with red antennx, palpi, and feet, the elytra smooth, each having three deep punctures. Julodes Rothii, St., from Jerusalem; Lycus appendiculatus,; St., from Sencgal, allied to L. foliaceus, Sch.; Hydrophilus substriatus, St., from the neighbourhood of Cassel; 3 Mexican species of Phanæus; Scarabæus Petiveri, Erichs. (Dejeanii Buq., Golofa Portcri Hope); 7 Mexican species of Pelidnota; Amphicoma Papaveris, from Jerusalem; Chiasognathus Grantii, $\delta$ and + (two brilliant figures); Ryssonotus nebulosus, Kirby; Lucanus turcicus, from Constantinople; with 6 plates in the club of the antennæ; my Xyphodontus 
Antilope, from Caffraria, under the name of Corypticus capensis, Dej.; Xopherus variolosus, from Mexico; Amycteres paradoxus, from New Holland, allied to Curcnlio mirabilis, K.; Tachyopus (Tachygonus, Dej.) Lecontei, a curious little weevil from South Carolina; Purpuricenus Dalmatinus, St., from Dalmatia; Ozodes Mexicanus; Dorcadion tomentosum, from Nauplia; Saperda Græca ; Mesophalacrus Spinolæ, from New Holland, an interesting genus, allied to Sagra and Donacia, already previously figured in Griffith's Animal Kingdom, Insects, pl. 67, fig. 2, under the incorrect name of Carpophagus Banksii; and also in the third part of Mr. Hope's Coleopterist's Manual, pl. 2, fig. 6; where the name of Mecynodera picta is given to it; and Platyauchenia limbata, a new genus from Brazil, allied to Alurnus.

These descriptions and figures constitute, in fact, the only valuable part of the work; for if the possessor of cvery secondrate collection of Coleoptera, like that of the author, were to undertake such a catalogue as this, giving names only, without descriptions, to hundreds of new specics, already, perhaps, named in Dejean's Catalogue, what endless confusion in the nomenclature of the order! How much better would it be to undertake but a single family at a time, describing all the new species in it? Mr. Hope has set the example, in publishing such a catalogue of portions of the Hemiptera, and proposes, on his return from Italy, to follow the same plan in another very extensive tribe.

Considerazione sopra i costumi degl' imenotteri dei. G. Sirex, Fab., E sopra il miglior posto dei Sireciti nel metodo razionale. Memoria del Marchese Massimiliano Spinola. Genova, 1843.

Is this memoir, the Marquis of Spinola, after stating the general opinion anongst naturalists, that the Siricidæ in their larva-state are wood-feeder's, and more especially mentioning the researches of Rosel von Rosenhoff, Jurine, Hartig, and Sells, * which supports that opinion, takes up the observation of Saint Fargeau, published in the Encyclopédie Méthodiquet, in which the parasitism of that group was first asserted, and mentions, in support of it, that he received in 1841, from the Marquis Carlo Durazzo, a specimen of Sirex Gigas, inscribed, "Parasita in larva di Far-

* Proceedings of Entomological Society of London, May, 1838.

+ Vol. x., p. 770 , M. Saint Fargean has again insisted on his vicw of the habits of the genus, in his Hist. Nat. Hyménopt., i. p. 5, note 3 . 
falle"-parasitic in the larva of a butterfly-that Signor Franchi had informed him that he had reared another from the larva of Papilio Machaon; adding, in a supplenentary note, that Signor G. B. Villa at Milan possessed a specimen of a Sirex, which he assured him, "era pure sortita dalla larva di un Papilio, sotto ai di lui occhi e nel di lui gabinetto." Upon these statements, the author proposes a fresh modification of the classification of the Hymenoptera, in order to make it accord with their supposed parasitic habits.

Having entered into the qucstion of the habits of this family at considerable length, in the 2nd volume of my Introduction to the Modern Classification of Insects, where I have reprcsented the various parts of the mouth of the Larva, I shall only observe that the numberless instances on rccord of species of this genus making their appearance out of the wooden flooring of newly-built houses, $\dagger$ quite overturns the statements of their being parasitic in the bodies of the caterpillars of butterflies; whilst the structure of the mandibles of the larvæ of Sirex, eminently fits them for gnawing through hard substances, and that the mandibles of Parasitic Hymenopterous larva are entirely of a different construction. Comp. figures, 70, 3, 4, (vol. ii. p. 94), 72, 20, (p. 115), and 76 15 (p. 140 of the 2 nd volume of my work abovementioned).

OSSERVAZIONI SOPRA I CARATTERI NATURALI, DI TRE FAMIGLIE D' INSETTI imevotteri ; cioè, le Vesparie, le Masaride, e le Crisidide. Memoria del Marchese Massimliano Spinol.A. Genova, 1843.

Commencles with the axiom, that " $\mathrm{i}$ migliori caratteri entomologici sono somministrati dalle forme esterne, e che le migliori forme sono quellc che mettono in evidenza la miglior leggc organica," the author has in this memoir entered into a profound revision of the physiological peculiarities of the chief hymenopterous groups, of which it is impossible to give an abstract; but of which the summary is contained "nel quadro sinottico che segue ":-

* Vol. ii. p. 117 and seq.

t The author gets over this diffeulty by supposing that they are ordinarily parasitic upon wood-boring larva of Coleoptera, and only oceasionally so in Lepidopterous larva; but, in those parts of England where the Siricida occur, we have not any xylophagous larva fitted for the Siricidæe to exercise thcir parasitism upon. 
Lcgge organica.

Carnttere estermo.

Famiglie.

$\left.\begin{array}{l}\text { 1. Aventi la facoltà di muo- } \\ \text { rere a piacimento il loro abdome, } \\ \text { senza avere da muovere previa- }\left\{\begin{array}{c}\text { Ale piegate longitudinalmente } \\ \text { nel riposo, colla costa della piega- } \\ \text { tura paralella all' asse del corpo. }\end{array}\right.\end{array}\right\}$ 1. Vesparie.

Monographie der Familen der Pflangentäuse (Phytophthires). Von J.

H. Kaltenbach. Aachen, 1843. 8ro. 222 pp., and one plate.

It is rather remarkable that, whilst the extraordinary plysiological peculiarities exhibited by the Aphides, in respect to their modes of reproduction, lave attracted the notice of every Naturalist, so few attempts have been made to describe the very numerous species of which the family consists. It is true, numerous species are indicated by Linnæus, Fabricius, and others, but, with scarcely any other description than that of the name of the plant on which they are found. In our own country, many species were well figured by Harris, long ago, in his "Exposition of English Insects," and a most extensive series of species, together with the plants which they attack, was formed by Mr. Haworth, who was induced to place them in Mr. Donovan's luands, with the view to their publication with figures; the latter author giving up to Mr. Haworth, in return, a unique specimen of the splendid Indian grasshopper, since published by Donovan, under the name of Gryllus Donovani, in the Naturalist's Repository. Unfortunately, the latter never proceeded witl the contemplated work: the collection, formed with so much care, was returned, half-eaten by mites, to $\mathrm{Mr}$. Haworth, and at the sale of his collection, it fetched the price of one shilling!

On the Continent, the works of Hausmann, ${ }^{*}$ Kyber, + Schrank, $\neq$

$$
\text { * Illiger's Mag., rol. j. † Germar's Mag., vol. i. } \quad \ddagger \text { Fauna Boica. }
$$


Burmeister,* Zetterstedt, $\uparrow$ Van Heyden, $\neq$ and especially of Dr. Th. Hartig, $\S$ have, by degrees, contributed considerable materials towards the knowledge and classification of these insects, and we have now a volume upon the family, from the pen of M. Kaltenbach, of Aix-la-Chapelle.

An introduction of 40 pages gives a general account of the structure, physiology, and habits of these insects; which, according to their mode of generation, form three principal groups.

1. Vivi-oviparous (G. Aphis and Lachnus).

2. Oviparous (G. Chermes, Phylloxcra Tacuna ?)

3. Viviparous (G. Tetrancura, Pemphigus, Schizoncura, and probably the underground genera Forda, Rhizohius, Paracletus, and Trama).

These genera are characterised in the following tabular distribution :-

1. Abtheilung. Winged species, Blattlausc.

Fore-wings with a hiramos ecubitus :

Antenna 7-jointed, long _ . . . . . 1 G. Aphis.

"6-jointed, short . . . . . 2 G. Lachnus.

Foro-wings with a l-rmmose cuhitus :

Antennæ 6-jointed, \&c. ․ . . . . . 3 G. Schizoneura.

"5-jointed, \&c. . . . . . . . 4 G. Vacuna.

Fore-wings with a simpic cubitus.

Fore-wings with 4 oblique veins, antennæ 6-jointed.

Hind-wrings with 2 ohliqque veins . . . . . 5 Pemphigus.

"witl 1 oblique rciu . . . . . 6 Tetraneura.

Fore-wings with 3 ohlique reins, \&c. :

Antennæ 5-jointed, \&ic. . . . . . . 7 G. Chermes. " 3-jointed, \&c. . . . . . . . 8 Phylloxera.

2. Ahtheilung. Wingless suhterranean species, Hyponomcutes.

Autennæ 6-jointed.

Last joint of antennæe thick, longer than the preceding . 9 G. Rhizobius. " " slender, shorter " 10 G. Forda.

Antennæ 7-jointed, last joint rery small :

Hind tarsi long and jointless . . . . . 11 G. Trama.

$"$ " two-jointed . . . . $12 \mathrm{G}$. Paracletus.

Of the genus Aphis L. 119 Species are descrihed :

" Lachnus, Ill. 13 species - - (Aphis Quercûs, Linn., A. Roboris, Linn. \&c. G. Cinara, Curtis).

"Schizoneurn, Hart, 6 species . . (Aphis lanigera, Ulmi, \&c.)

"Vacuna, Van Heyd. 2 specics : (A. dryophila, Sehk. and a n. sp.)

" Pemphigus\|, Hart., 7 species - (A. bursarius, L. \&c.)

"Tetraneura, Hart., 1 species $\quad$ (A. Ulmi Degeer).

"Chermes I, Linn., 4 specics . (Ch. Ahietis, Linn, \&c.)

\footnotetext{
* Handb. d. Ent., vol. ii. $\quad \begin{gathered}+ \text { Insceta Lapponica. } \\ \text { In Germar's Zeitschrift, vol. iii. }\end{gathered} \quad$ In Museum Scckenb. II The name of Brysocrypta Haliday (Westw. Gcn. Synopsis, Brit. Ins., p. 118), must be retained for this genus.

T1 consider that the name, Adelges Vallot, ought to be given to this genus.
} 
Of the genus Phylloxera, B. do F., 1 species . (Vac. coccinea, Van Heyd. P. Querene,

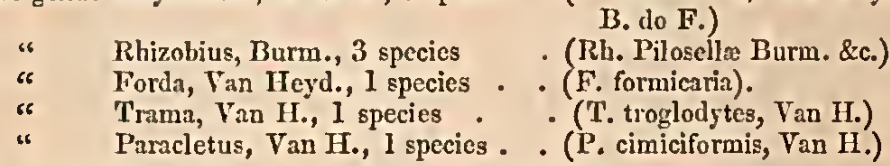

The genus Atheroides Haliday* appears to be unknown to the continental authors, whilst the generic name Eriosoma, Leach, (Myzoxyle Blot.) must take place of that of Pemphigus, and be restricted to such species as differ from A. bursarius. In like manner, my generic name Thelaxes is synonymous with Vacuna, as restricted by Kaltenbach, Th. Quercicola, W., being, most probably, V. dryophila, Van H.; Vacuna coccinæa, V. H. being removed to tho genus Phylloxera Fonsc.

A double index, first of the insects, and second of the various plants attacked by them, terminates the work.

Spécies et Iconographie générique des Aximaux articulés; ou Représentation des Genres avec leur description, et celles de toutes les Espèces de cette grande Division du Règne Animal : ouvrage formant une série de Monographies complètes. Par M. F. E. Gú́rin-Mínevilde. 8ro. Paris, 1843. Livraisons $l$ et 2.

The work of which I have given the title at full length above, promises to be of the greatest service to entomologists. The extensive collections in Paris opened to the author's researches, his own excellent cabinet, library, and folios of drawings, are all laid under contribution to perfect this work, which has been so long announced, and so much longer the object of the author's attention. Instead of commencing the Coleoptera with the Cicindelidx and Carabidx, the author has undertaken the illustration of the less known group of Cebrionidx and allied genera; and we have, in the two livraisons now published, excellent illustrations and descriptions of tho following genera and species:-Rhipicera, $11 \mathrm{sp}$; Sandalus, 5 sp.; Scirtes, 16 sp.; Eucinetus, 2 sp.; Ptyocerus, 4 sp.; Selasia, 3 sp.; Chamæripis, $1 \mathrm{sp.;} \mathrm{and} \mathrm{Basodonta,} 1 \mathrm{sp.}$ Each genus is represented with its details in a separate plate, drawn with all the skill of its excellent author. 



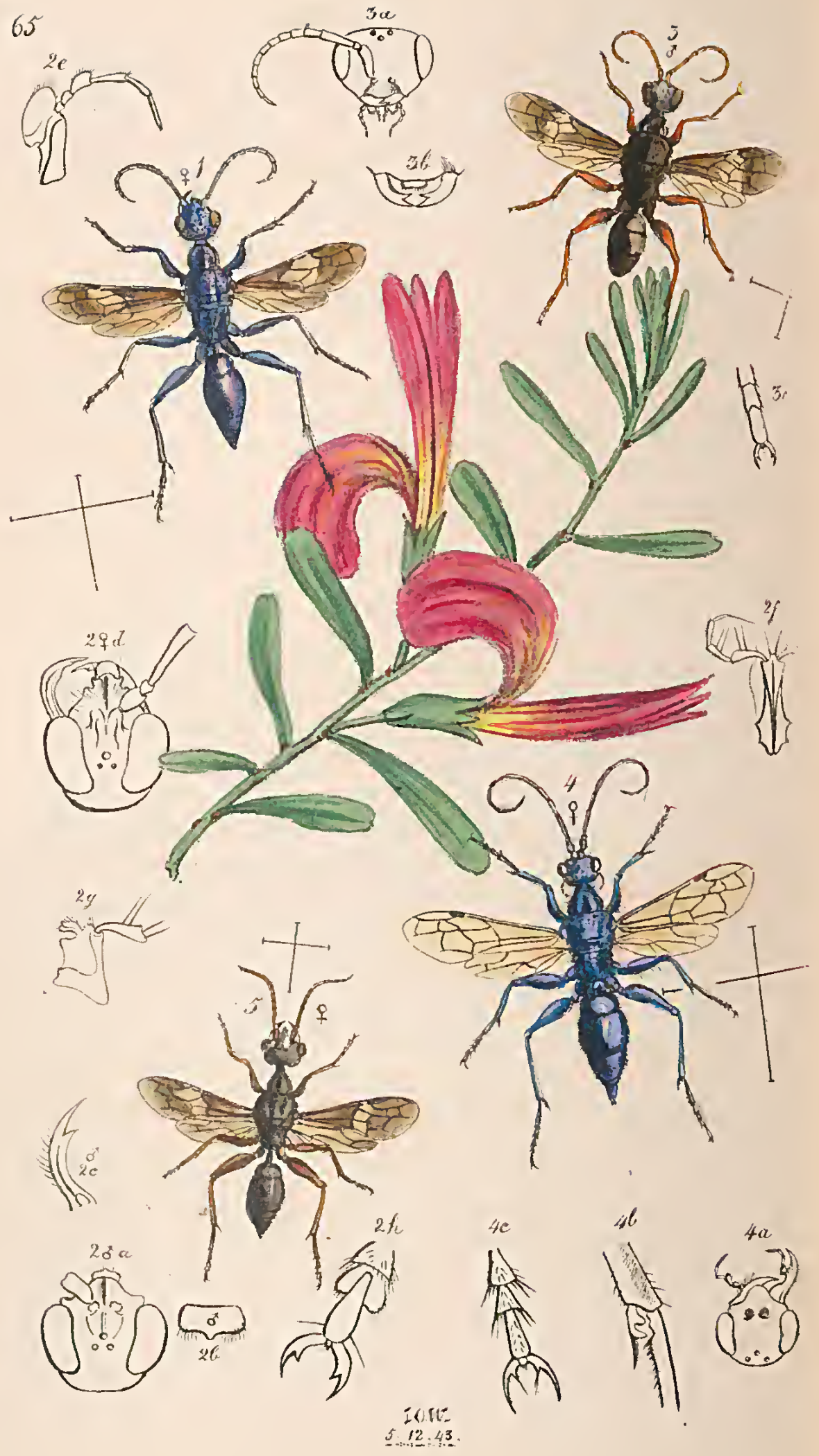




\section{PLATE LXV.}

ILLUSTRATIONS OF SOME GENERA OF FOSSORIAL HYMENOPTEROUS INSECTS, BELONGTNG TO THE FAMITY SPHEGID $\mathbb{F}_{\text {. }}$

Tre curious genus Chlorion of Latreille, (Ampulex Jurine) having been raised by Shuckard * and Dahlbom $t$ to the rank of a family, distinct from the Sphegidx, it becomes interesting to examine its precise structure, as well as that of some new forms closely allied to it; in order to discover the propriety of such a step. In the third volume of the Transactions of the Entomological Society, I established two new genera, bearing such a relationship; but, it happened, that at that period I was acquainted only with one scx of each of them. Having since become acquainted with the opposite sexes of each, and having likewise observed in the Collection of the British Nuseum another undescribed form, I have in the accompanying plate completed my illustrations of these groups, by figuring the sexes litherto wanting, as well as numcrous details of the genus Chlorion itself, together with a new and beautiful species of that genus from the Collection of W. Burchell, Esq.

\section{GENUs.-CHLORION, Latreille. + (AMPULEX Jurine.) \\ CHLORION PURPUREUM, Westw.}

(Plate 65, fig. I.)

C. lrete purpureum, valde punctatum, mesonoto obscuriore, metanoto transverse striato, carinisque novem (2da et 3 tia utrinque a medio discretis) antennis clypco tibiis tarsisque nigris ; alis anticis fuscis fascia lata pone merlium alisque posticis sub-loyalinis; abdomine postice minus compresso quam in $\mathrm{A}$. compressiventre Guer.; collare postice tuberculo elevato instructo; mandibulis nigris apice piceis; tarsorum articulo penultimo minori quam in congeneribus, articulo basali antcnnarum subtus rufescenti. ?

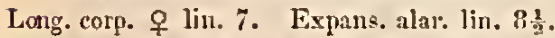

Hahitat in Africa Austualiori, D. Burchell.

In addition to this species and the original type of the gemus Chlorion compressun, the following species have been recently lescribed and figured.

Species 3.-CHtorioN CINIIPES, Westu. (In Trins. Eut. Soc. 3, p. 230.) From the Cape of Gond Hope.

* Cabinet Crelop. Nat. list. lns. p. 180. See my observations liereon in Trans. Ent. Soc. 3, p. 230, note**

+ Hymenoptera Enropea, Lund. 1843, p. 29 : in which excellent work the genus Dolichurus is remorcd to the family Pompilide, whilst in his previous 'Dispositio methodica', Part 1, Lund. 1342, he has placed $A$ mpulex and Dolichurus together as the first section $\Lambda$. of Pompilida,

$\ddagger$ Sue Trans. Ent. Soc. vol. 3, p. 22\%, for the rensons which induce me to rignd the Spliex compressa as the truc type of the gerus Chlorion.

so. XVI1.-1st JANLART, 18̄tt. 
Specirs 4.-CHLORION (AMPULEX) ANGUSTICOLLE, Spinola. (In Ann. Soc. Ent. dc France 1841, p. 108*.)

From Gayenne.

SPECIES 5.-CILLORION (AMIPULEX) RENEUM, Spinola. (Iu Op. cit. p. 110.) From the const of Malabar.

SPECIEs 6.-CHLORION (AMPULEX) COMIPRESSIVENTRE, Guérin. (Icon. R. An. Ius., pl. 70, fig. 4.)

Specres 7.-CHLORION GUERINi, Dahliom. (Hym. Europ. p. 29.)

The following is the description of the figures illustrating the structure of the insects of this genus, taken from C. compressum. Fig. $2 a$ is the head of the male, with the mandibles removed, showing its clypeus to be less porrected than in the female (fig. $2 d$.) Fig. $2 b$ represents the labruu detached, and $2 c$ the mandible of the male, with a strong tooth on the inside below the apex. Fig. $2 d$ is the head of the female, with the mandibles and base of the antenna; the former with the inner edge slightly produced below the apex. Fig. $2 e$ is the maxilla; $2 f$ the mentum and labial palpus, seen from beneath; and $2 g$ the same seen laterally, this figure showing the inflected lobes of the labiuru. $2 h$ represents the apical portion of the tarsi, sliowing the lobed penultimate joint and bifid ungues.

Genus trirogMA, Westu.

(Trans. Ent. Soc., vol. iii. p. 223.)

Hoc genus olim ex individuo unico maris conditum, nunc cbaracteribus utriusque sexûs confirmatum.

Corpus subelongatum punctatum, abdominc longis griseis undique villosum. Capat anticc clypeo parum producto subdeclivi (fig. 4 a) tuberculoque inter partem inferiorcm oculorum armato, in quo insident astenns. Oculi magni latcrales margine autico parum cmarginato. Ocelli 3 , in triangulum dispositi. Antennx in utroque scxu longa graciles, ô filiformes, his subconvolutis. Labrum minulissimum exscrtun obovatum depressnm menbranaceum. Mandibuls of validx curvatx apicc ncute intus dento latissimo (angulo basali valde promiucnti et acuto) : 우 multo angustiores, pone medium marginis interni denticulis tribus parvis iustructio. Palpi maxillares mediocres articulo Imo minuto 2bus proximis majoribus, ultimis tribus clongatis et gmcilioribus. Palpi labiales 4-articulati articulo basali longiori, 2ndo breviori. Thorax oblongo-ovatus; collare uesothoracc multo augustius antice angustum lateribus rotundatis, supra inpressione longitudinali in lobos duos supra angulatos divisum; metathorax subconicus lateribus subangulatis discoque carinis obliquis notato. Alæe antice cellula unica marginali, ad apicem haud appendiculata; tribnsque completis, cum quarta inclsoata submaryinalibus, harum cellula I ma elongata accipit versus apiccm venam primam recurrentem, ccllula 2 da minori subtriangulari accipit pono medium renam $2 \mathrm{~m}$. recurrentem. Pedes graciles femoribus ad basin clavatis, tarsis longis gracilibus articulo 4 to simplici, unguibus bifidis terminato. Tibia antice of fcre inermes, setis minutis instructæ, calcari majori intus lata bipartita instructæ (fig. $4 b$ ). Tarsi antici o spinulis ad apicem articulorum tantum (fig. $4 c$ ) setisque rigidis minntis subtus instructis. Tibise 4 posticx etian fere inermes, bicalcaratie, tarsisque codem modo almatis. Abdomen ot breviter petiolatum, 3-annu-

* This specics is a native of Caycnne. being the only instance $I$ am hitherto acquainted with, of the occurrence of an species of this or the allied genera. in South America; if, indeed we except Pcrty's genus, Trigonopsis, which will, I think, be fonud to be closely allied to them. 
latum, punctatum, segmentis postice parum coarctatis intermedio majori ; 96 annulatun, 3bus ultimis minutis.

Obs.-Descriptionem fusiorem maris in opere citato invenies.

Specifa unica.-Trirogia Corrulas. (Plate 65, fig. 4.) ?.

T. cœrulea punctata griseo-villosa, antennis tibiis tarsisque nigris, alis hyalinis stigmate venisque nigris, metathorace utriuque supra linea clcvata areaque media basali notato.

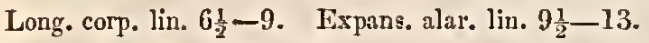

Habitat in partibus medianis et septentrionalibus Indix Orientalis. In Mus. Hearsey et Saunders.

Syw.-Trirogma carulea, Westw., Trans. Ent. Soc. iii., p. 225. Plato 12, fig. 3 o.

Several specimens of this interesting insect, which is intermediate between Chlorion (Ampulex) and Dolichurus, captured by my friend, Colonel Hearsey, in Central India, have enabled me to complete the characters of the genus which I established for its reception in the Transactions of the Entomological Society.

\section{APHELOTOLIA, WESiw.}

(Trans. Ent. Soc. Lond., Tol. iii. p. 225.)

Hoc genus olim ex individuis feminis tantum descriptum nune characteribus utriusque sexus confirmatum.

Caput latum facie depressa antice parum producta, haud tuberculata (fig, $3 a$ ). Mandibulæ of curvatio, et interne ante apieem dente acnto armatie (fig. $3 b$ ); $q$ crassæ versus basin suhito constricta apice acuto, dente interno parvo acuto armatre. P'alpi maxillares 6 -articulati articnlis dnobus basalibns brevibus fere aqualibus, 3 tio paullo longiori et crassiori, reliquis 3 bus fere $x$ qualibus sensin gracilioribns. Palpi lnbiales 4-articulati fere filiformes articnlo basali longiori, reliquis subaqualibus. Antennxe breriores subfiliformes, in tuberenlo litul insidentes; articulo 1 mo longo; 3 tio longissimo. Collare subconicum dorso in medio plano. Metatloorax supra planiusculus cninis duabus elevatis laternlibus, dorsoqne lineis circiter 10 irregularibus longitudinalibus, elevatis striis transversis conncxis.

Abdomen of thorace multo minus, quasi 6-annulatum, segmentis 3 bus ultimis rcro minntissimis ; 우 longius apico conico, scmmentis 3 bus brsalibus maguis, 4 to minori reliquis minutis; segmentis duobus basalibus in utroque sexu nitidis lavissimis, reliquis quasi sericcis et obscurioribus. Alwo breves, antice cellula unica marginali, apico haud appendiculata, cellulis quatuor submargiualibus; Ima majori, (in medio ad apicem appendiculata) venam primam recurrentem cxcipiente; $2 \mathrm{da}$ parva antice attcnuatr; 3 tia subquadrata venam recurrertem 2 dam versus basin excipiente; th ad apicem alw currente. Pedes $q$ elongati omnino inermes et ciliis destituti. Tarsorum articulus penultimus simplex (fig. $3 c$ ) ungues in medio subtus dente parvo instructi.

\section{Specifs unica.-Aphrlotoma Tasmanica. (Plate 65, fig. 3 ô.)}

A. nigra pedibus rufis alis fuscis, anticis fascia media alba. Long. corp. lin. 4-4 $\frac{\pi}{4}$. Expans. alar. lin. 6.

Habitat in Terra Van Diemenii.

q In MIus, nostr. Commun. Dom. Ewing, and $\hat{b}$ in Mlus. W. W. Saunders, F.L.S.

Sys.-Aphelotoma Tasmanica, Westw. Op. Cit. p. 226, pl. xii. fig. 4 오.

ธิ. Mandibulse rufe extremo apice nigro. Antennæe rufe articulis 6 ultimis nigris; perles ruf coxis trochanteribus, ct basi femorum prosertim in anticis nigris.

오 Mandibulw nigra apico picex, antenna nigrae articuli 4 ti apice, 5 to toto, et 6 to fere toto rufescentibus. Pedes cum coxis omuino rufis.

Obs.-Descriptionem fusiorem hujus sexûs invenics in operc citato. 


\section{RHINOPSIS, Westwood.}

Genus uovum, e Georgia Ancricæ septentrionalis; Chlorioni affine at venis alarum anticarum distinctum.

Caput depressum, clypeo attenuato. Mandibulæ o integra falcatæ; antennæ sat longx graciles, articulo 3tio longo graciliori. Collarc triangulare in lobos duos linea impressa longitudinali divisum. Metathorax costatus et transversaliter striatus. Petiolus abdominis longior quam in Chlorionibus veris. Abdomen segmento 2ndo maximo. Pedes longi graciles simplices tarsorum articulo 4 to brevissimo at subtus bilobo: ungucs subtus in medio dento instructi. Alæo breres anticse cellula unicr marginali, ad apicem parum appendiculata; duabus completis 3 tiaque inchoata submarginalibus harum prima longa accipit vcnam lam recurrentem, $2 \mathrm{da}$ subquadrata accipit venam 2dan recurrentem, 3 tia apiecm alse hand attingit.

Species unica. Rulnopsis Aвbottir, Westw. (Platé65, fig. 5"q.)

Rh. nigra pedibus piceis tarsis pallidioribus; mandibulis pallide piceis; alis hyalinis fascia lata fusca ante altcraque pone medium fuscis.

Long. corp. lin. 4. Expans nlar. lin. 4.

Habitat in Georgia America Sept. D. Abbott. In Mrus. Britan.

Obs.-The unique specinen of this insect in the British Museum collection, is without any indication of locality. My authority for giving it as a native of Georgia, in America, is Abbott's collection of drawings in the British Museum ; in the twelfth volume of which it is carefully figured, under the number $\operatorname{xxx} 95$, and where it is stated to have been taken on the 20th April, in oak woods, but that it is very rare.

The plant represented in the plate is the Australian Templetonia glauca. 



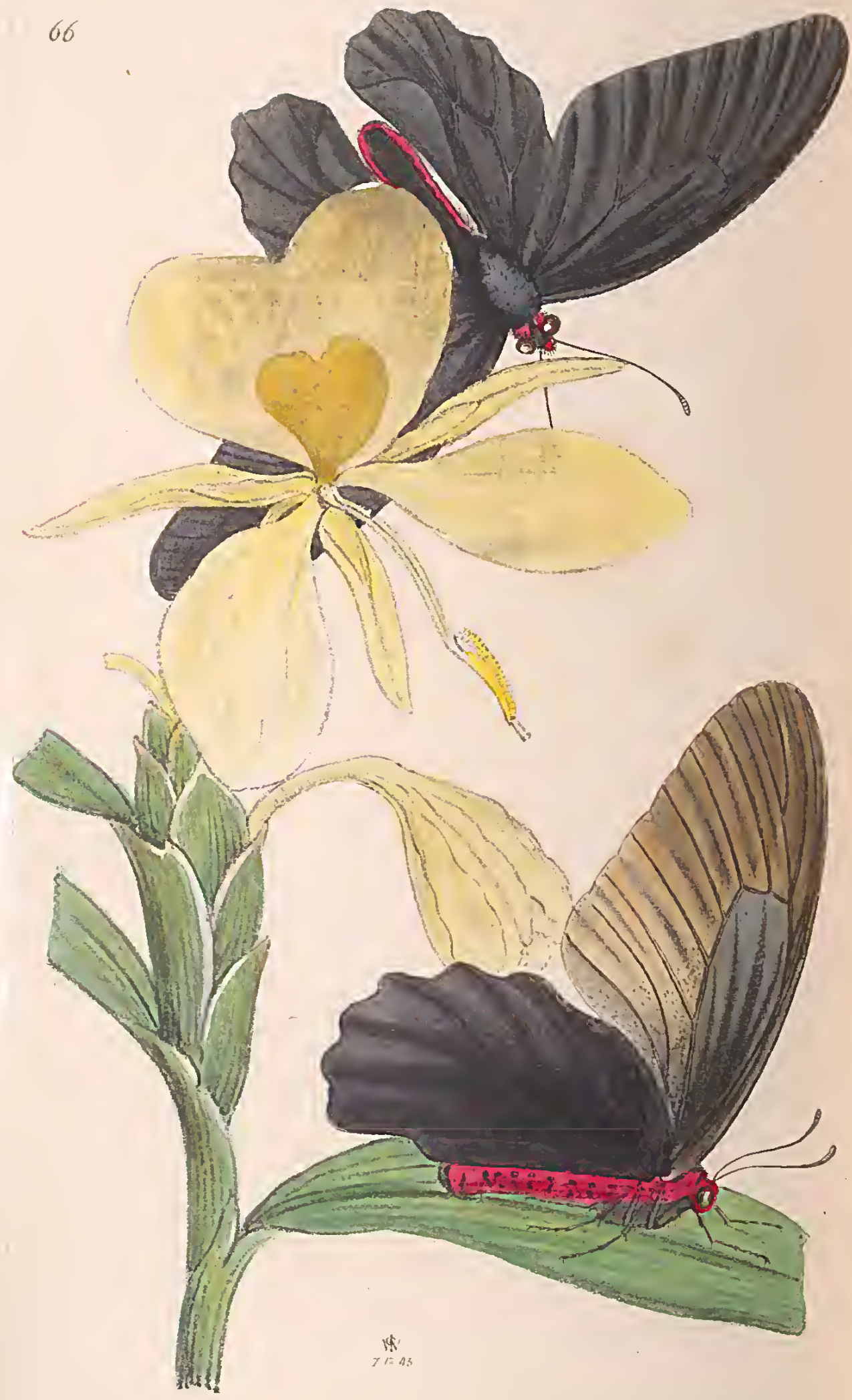




\section{PLATE LAVI.}

\section{ILIUSTRATIONS OF TWO HITHERTO UNFIGURED SUPPOSED SPECIES \\ OF THE GENUS PAPILIO.}

\section{PAPILIO ASTORION.}

(Plate 66, fig- sup.)

P. alis elongatis valde angustis, posticis subsinuatis ceaudatis ; omnibus cyaneo-nigris immaculatis; anticarum dimidio apicali subtus obscurè griseo-nigricanti venis strigisque intermediis nigris, capite antice cun lateribus collaris, thoracis marginibusque posticis segmentorum ventralium abdominalium sanguineis $\hat{\delta}$.

Expans, alar, unc. $4 \frac{3}{4}, 5$.

Habitat. Sylhet Ind. Orient. In Mus. Soc. Ent. Lond. ct Doubleday,

Sys.-P. Astorion, Westw. Ann. Nat. Hist. 1812. p. 37.

\section{PAPILIO CHARA.}

(Plate 66, fig. inf.)

P. alis anticis latis apice rotundatis, anticis basi nigris apicc sensim infuscatis anguloque anali albidn, venis strigisque intermediis nigris, alis posticis cyaneo-nigris margine sinuatis ecaudatis, capite antice ct lateribus collaris thoracis et abdominis sanguineis nigro maculatis 9 . An femina precedentis.

Expans. alar. unc, $5 \frac{1}{4}$.

Habitat Sylhet. Ind. Or. In Mus. Brit. et Doubleday.

Syn.-Papilio Chara, Westw. in Ann. Nat. Hist. 1842, p. 37.

Papilio Varuna, White in Entomol. p. 280.

IN assigning to this supposed species the name of $\mathrm{P}$. Chara, I desired to show its possible relation as the opposite sex to P. Astorion.* Their specific identity can at present, however, be only conjectured. Should they ultimately prove to be so, it will be in accordance with the ordinary practice, to retain the name of the male as that of the species.

The plant represented in the plate, is the Nepalese Hedychium coronarium Koen.

"Next to that Book which shows to guilty man

How he through mercy infinite, may gain

More than he lost in Eden, I do rank,

And justly so, street Nature's varied lore,

For well it records many a glorious truth

Which in that better record stands revealed.

The furious hurricane that rends the heavens

And makes the scared and desolated earth

\footnotetext{
* These are the names of the hounds of Boötes.
} 
Reel like a drunkard; the resistless flood, The barren waste; nay, e'en the very thorn Which wounds our finger when we pluck the flower, And noxious weed that inocks the liope of toil, Do all attest one truth, man's foul revolt.

The changing seasons, winter's death-like reign So soon succeeded by the bloom of Spring, What are they but the types of man's decease, And resurrection? The blithe birds which perch Beneath our cottage eares, the smiling florers Which decorate the hedge-row and the mead, Do they not mind us to repose our trust

On Hry who feeds and clothes them day by day?" What says the lip of Wisdom? "Mark the fowls. Which neither sow, nor reap, nor store in barns, And yet your hearenly Father feedeth them. Consiler too, the lilies how they grow, They neither toil, nor spin, and yet I say, That Solomon in all his glorious pomp Was not arrayed like these. Wherefore, if GoD Thus clothes the grass, so soon to pass away, And feed the fowls of Heaven: Shall He not then Much rather for your daily wants provide?

O ye of little faith!"

Recollections of the Lakes. 


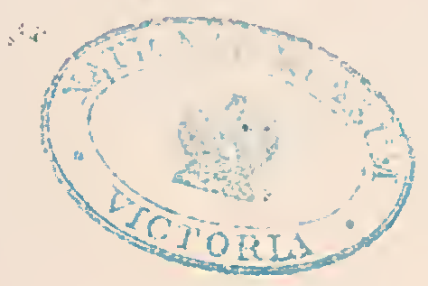




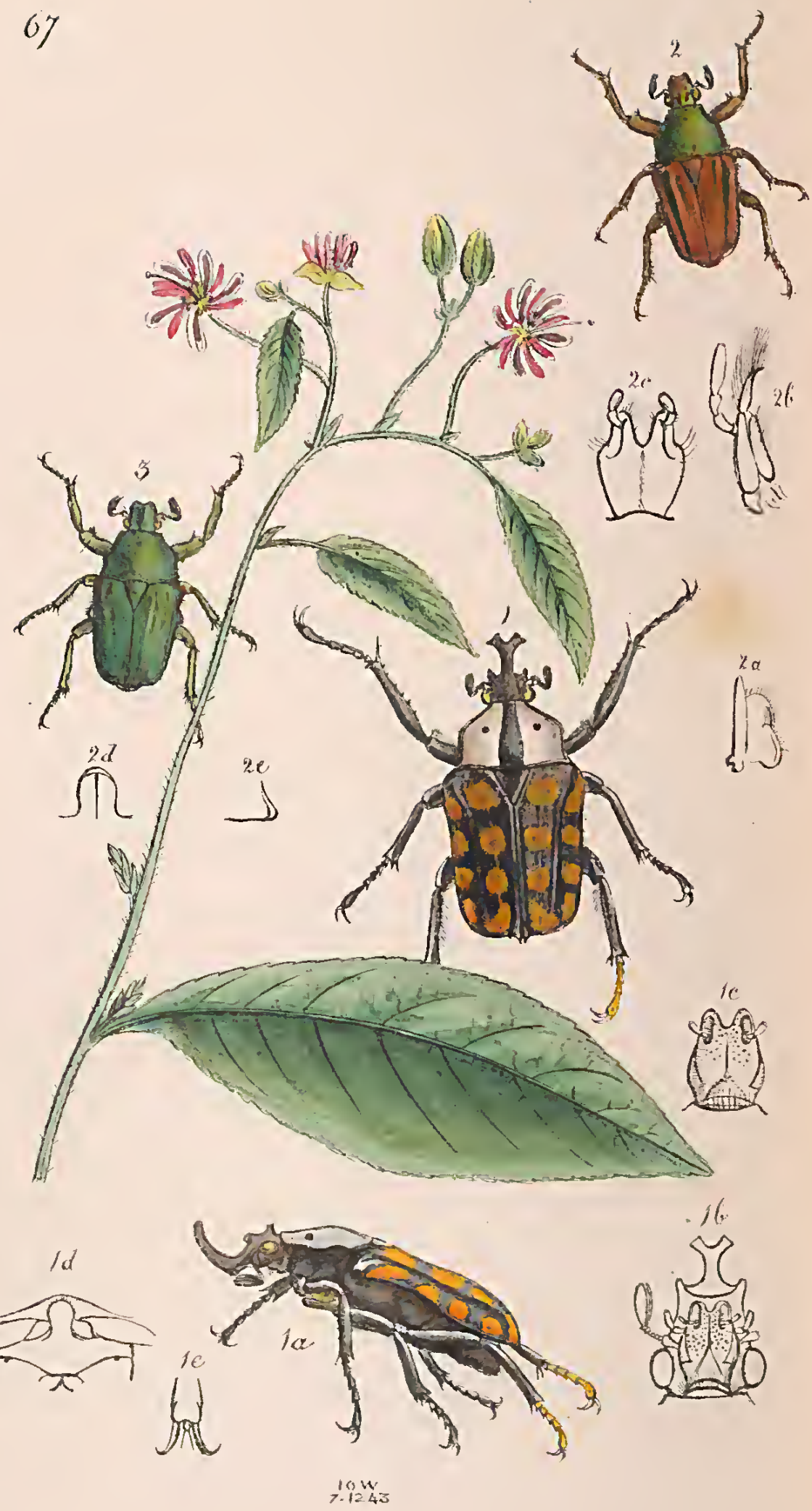


PLATE LXVII.

ILLUSTRATIONS OF TWO NEW GOLIATH BEETLES.

FAMILY.CETONHDA.

SUB-FAMLY-CGOLIATIHIDES.

Genus-Ceratorhina.

Sub-genus Novurs.-AMLAURodes, Westw.

CERATORIINA (ANAURODES) PASSERINII (MELLY'S MISS.)

(Plate 67, fig. I.)

The insect here represented belongs to that section of the genus Ceratorhina, which has the anterior tibix of thc males denticulated only on the inner edge (see vol. i., p. 171). As it differs from the Dicronorhine in the form of the horn of the head, and from the Eudicelli in its obscure colours, I have considered it as a distinct sub-genus, which cridently leads to Chcirolasia. I regret that I am able to give no account of the structure of the female, nor of the formation of the maxilla, my figures being copied from a drawing by Signor Passerini, kindly forwarded to me by A. Melly, Esq., for publication in this work.

Char. Subgener. Tibin $\hat{o}$ nntice intus denticulatæe extus incrmes. Tibiæ 4-posticre extus inermes. Clypens $\hat{a}$ in cornu furcatum porrectus. Corpus obscurum, nec metallieum (sericeum?); elythis naculis numerosis pallidis distinctum. Pedes antici longiores. Elytra ad apicen sutura sub-bi-spinosa. Tibix 2 postice intus ad basin setosx. $q$ ignota.

Char. Specif. Nigra opaca, prothorace allido, linea tenui marginali, altcra latiori mediana punctisque duobus rotundatis nigris; elytris tricostatis maculisque 16 .fulvis forma et magnitudine subxqualibus ornatis; tarsorum articulis tribus ultimis in pedibus duobus posticis fulvis, unguibus apicibusquuc nigris.

Long. corp. lin. $17 \vec{b}$.

Habitat Mozambique.

Fig. 1, the insect of the natural sizc; $1 a$, the same seen latcrally; $1 b$, the underside of the head; $1 c$, the mentum and base of the head and maxillæ; $l d$, the sternum and base of the middle feet.

\section{ASTHENORHINA, Westw.}

Caput maris inermo clypeo parum emargiuato. Mandibulæe margine externo rceto (fig. 2 a). Maxilise lobo apicali porrecto acuto apice currato, dense penicillato, loho intemo incrmi (fig. 2 b). II I ntum ap̧ico late et profunde iucisum (fig. 2 c). Prothorax lateribus in medio ralde anculatis, et pone uncdium fere rectis et parallelis. Elytra apice iutegra. Fenora antica crassa, apice interne bidentata. Tibire antien intns inermes lectre extus pone incdium dente rudimentali instmeta. Tibise 4-postica pone nedium externe inermes interne ad apicen cmarginatæ et setosæ. Corpus supra opacum subtus nitidun. Sternum vix porrcetum (fig. $2 d, 2 e$ ). 
The size of the fore-feet removes this genus from the Heterorhinæ, whilst it appears to make the nearest approach to Tmesorrhina and A phelorrhina, vol. 1, p. 181.

The name which I proposed for this genus is derived from the Greek, and like those of most of the other groups in this tribe of beetles refers to the form of the clypens, which in this group is unarmed.

Sevirs unica.-Asthenorhina Turueri. (Plate 67, fig. 2, 3.)

13 . vitidis supri opacus interlum finlvo tiuctus, elytris parum costatis interdum lutels, fascia longitudinali ex humeris ad tuberculum subapicalc extensa viride, sutura nitida, pedibus cupreo plus minusve tinctis, antennis tarsisque nigris; thorace subtus lateribus albido setosis.

Long, corp. liu, 10.

Habitat Africa Tropicali, Ashantee. In Mus. D. Turner.

I am indebted to J. A. Turner, Esq., of Manchester, for an opportunity of adding this interesting species to the list of African Goliath beetles. The kindness of this gentleman, in submitting a considerable number of his rarest insects to the examination of Dr. Burmeister and myself, amply merits the trifling compliment I offer to him in affixing his name to this species.

The plant represented in the plate is the Grewia pubescens of Palisot de Beauvois. 


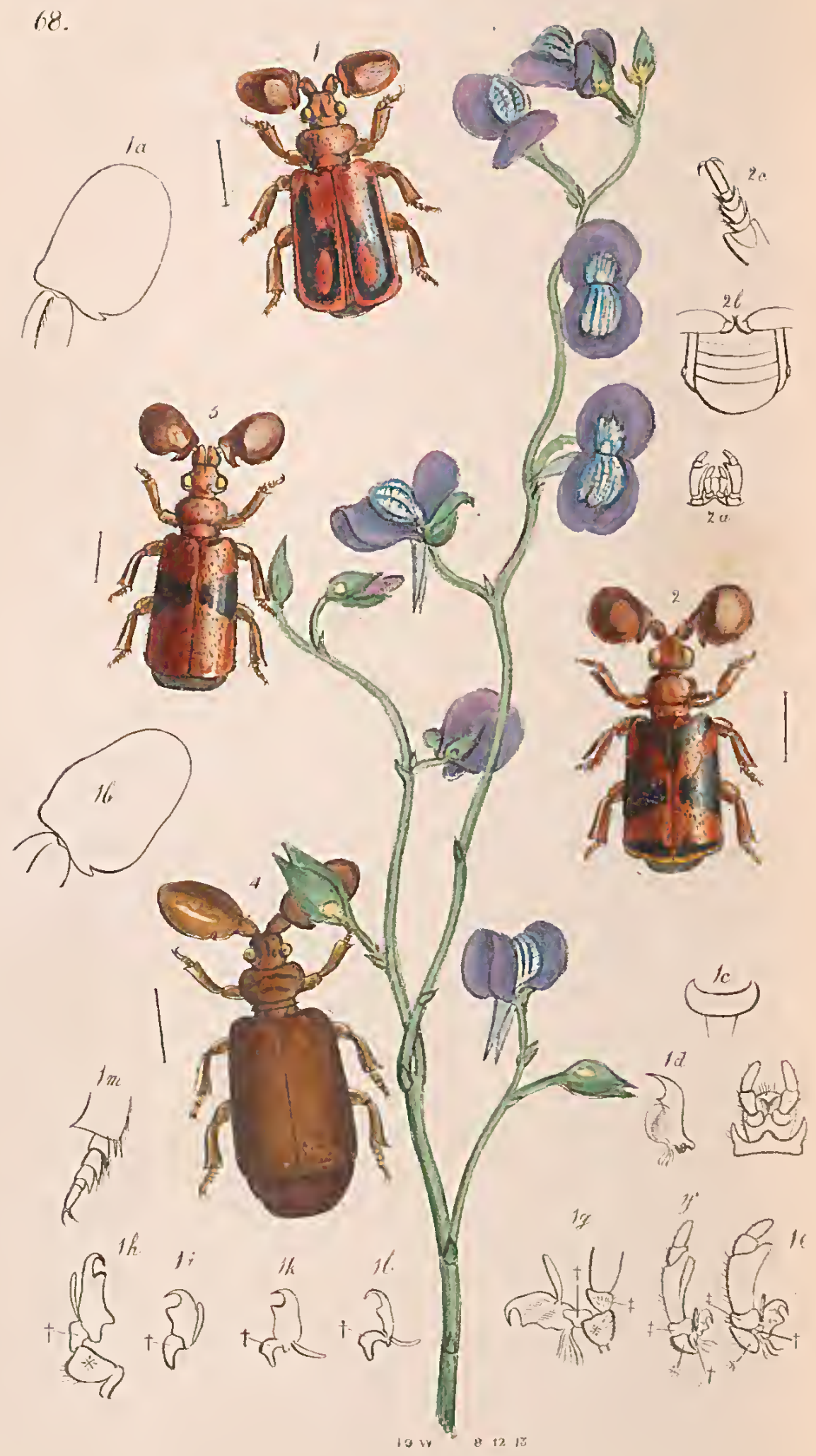




\section{PLATE LXVIII.}

MONOGRAPH OF THE COLEOPTEROUS FAMILY PAUSSID压.

(PART III.)

THE insects belonging to this curious fimily, which remain to be described in the present monograph, are distinguished from all those described in the two preceding papers (except Hylotorus Bucephalus) by apparently possessing only two distinct joints in the antennæ; the second of whicls is very large and irregular in its construction, occasionally exhibiting the appearance of constrictions, apparently indicating the situation of articulations. This is the case, for example, in a transversc impression near the basc of the great joint, in the species figured in the upper part of the accompanying plate, as well as in Platyrhopalus aplustrifer; whilst the indentations along the hinder margin of the same joint, in some of the specics of Paussus, may also, perhaps, be considered as indicating the same rudimental articulation. From Hylotorus, the species remaining to be described are distinguished by the possession of a nurrow contraction of the head belind the eyes, forming a kind of neck, and by the want of the two occlli, or ocelli-like tubcrcles, on the crown of the liead.

These species, from the construction of the labial palpi, form two generic groups: one (containing the old types of the genus, and therefore retaining the old generic name, Paussus) having the terminal joint of the labial palpi very long and slender, and the two basal joints strall; and the other having the two terminal joints of equal length, and generally possessing a large, broad, and subdepressed club to the antenne, whenec, upon the separation of this group from the former, in nyy paper in the Limnean Transactions, I applied to it the generic name of Platyrhopalus. It is to this genus that our attention is now to be directed.

\section{PLATYYRHOI'ALUS, JESTW.}

(Trins. Linn. Soc. Lond. vol. 16, p. 654.)

Corpus depressum. Capul thorace minus, porretum sulqquadiatum, postice in collum brcve contractum. Oculi magni pominuli latcualcs. Labrum sub-scmicirculare tenuc sctis duabus antice instructum (fig. 1 c). Mandibula cornese lenuissinze valde arcuata apice in dentem acutissinum terninte, interne uni- vel bi-dentate; memblanaque tenui sub- 
rotundata instructa (fig. 1 a). MTaxilla parva lobo-basali erustaceo, processu terminali rel interno plano acuto cornco valdo compresso mandibuliformi laterne interno uni- rel bi-dentato externoque stylo tenui exarticulato instructæe (fig. $1 e-1 l$ ). Palpi maxillares magni 4-articulati articulo basali brevi, 2 ndo maximo apicè interne oblique producto conpresso, 3 tio subquadrato, 4 to tenuiori subovato. Nentum breve transversum crustaceum, angulis anticis in spinam longam productis, medioque marginis antici subrotundè porrecto (fig. prox. $1 \mathrm{~d}$ ). Palpi labiales breves 3-articulati porrecti vel refiexi articulo Imo brevi * duobus ultimis subxqualibus, 1 wo erassiori, 3 tio tenuiori apice acuto. Lalium subqundratnm basi in lobos duos interne connexos (palpos gerentes) constructum, $\uparrow$ marginc antico integro, angulis anticis rotundatis. Antenna magna articulis quasi duobus, priori minori compresso, apicc obliquè marginato, angulo interiori supra producto ferè conico; tunc articulus? parvus subglobosus emarginatura prioris immersiss : cni insidet articulus ultimus maxjmus subplanus valde depressus et inferiori subtransversè impositus; margine omni compresso acuto basi truncatus et cxterne incisus rel dentatus: etiam juxta basin supernè transwcrsim impressus (articulorum divisionem refcrens); nee basi uncinatus. Thorax planus brevis transwersus latior, lateribus anticis rotundatis. Elytra thorace multo latiora, postice subtruncata oblongoquadrata depressa angulis posticis externc tuberculo ordinario instructis. Pedes bresiuseuli crassi, tilitis dilatatis, ealcaribus duobus, ad apicem armatis, angulis cxternis apicalibus acutis. Tarsi breves, 5 articulati, articulis tribus basalibus compressis intus pilosis, 4 to minuto ; 5 toque tenni longiori lavi eylindrieo, unguibus duobus acutis instructi. Alce ut in Paussis. Abdomen ely tris paullo longius, 4-articulatum articulis duobus intermediis brevissimis $\|$.

The insects of the present genus appcar to be intermediate between those species of Paussus which liave the prothorax not strongly constricted across the centre, and the Ceraptcri. In their biarticulate antennæ and the formation of their maxillary palpi, they approach the former; and in the general habit of thcir bodies, as well as in the formation of the basal joints of their tarsi, and in the tendency to articulation exhibited in the clava of their antennæ, they approximate to Cerapterus, Platyrhopalus angustus, and the two species which, in the Linnæan Transactions, I described under the names of "Platyrhopalus? lavifrons" and "Platyrhopalus? dentifrons," (but which I now find, by an examination of their trophi, to be species of Paussus, ) serve to prove the former relationship, whilst Platyrhopalus Melleii sufficiently attests the latter.

In a preceding article (pp. 10-12) I have quoted some observations by Dr. Burmeister, upon the construction of the wings of

* In the Linnoan Transactions (xvi. 655), and ante p. 5 , the joints of the labial palpi were deseribed as of equal, or vearly equal, length. The present description is made from a rery careful recent dissection of $P$. deuticornis compared with the other species.

+ In the specimen of P. denticornis which $I$ dissected fourteen years ago, the basal portion of the labiun seemed more regularly divided iuto two scapes, upon which the palpi are inserted, than in the specimen of tho same inseet recently examined.

¥ In my paper in the Linnæan Transactious, I overlooked this minute joint, whicb, howaver, I detected in P. Mellii and Westroodii, Linn. Trans. xvi. p. 681. and Ent. Trans, ii. pl. 10, fig. $4 \mathrm{~g}, 5 \mathrm{c}, 5 \mathrm{~d}$.

II Mr. W. W. Saundcrs'unique spceimen of P. Westroodii has the appearance of an additional basal articulation, which led we to figure the abdomen as 5-jointed in the Entomological Transactions. I find, however, the articulation is only apparent, and not real. 
these insects and the relationship which was thereby supposed to be proved to exist between the Paussidæe and the Carabidæ, as well as the want of relation between the former family and those groups of beetles with which it has been associated by Latreille and other authors, as well as by myself. It is due, however, to Dr. Burmeister, to observe, that it was not upon this character alone that lie was induced to affirm this relationship, having carefully reviewed the entire construction of the Paussidæ, and more especially investigated the structure of the maxillæ, considering that "le véritable caractère de la bouche d'un Coléoptère carnassier est la figure de la mâchoire et la construction du mando."

The following is Dr. Burmeister's description of the maxillæ of Platyrhopalus denticornis :-

"Les mâchoires ont un pédicule inarticulé cordiforme extérieurement corné, mais rempli de muscles charnus dans sa partie intérieure, muscles qui meuvent toute la mâchoire, et principalement le lobe interne de celle-ci, que j'ai nommé mando ou pièce manducateuse, puisqu'elle est la plus broyeuse, si un insecte prend une nourriture dure et non pas fluide. Cette pièce est d'une grandeur fort remarquable dans les Paussida comme les.figures de M. W Vestwood nous le montrent, et a en général la même configuration que chez le Platyropalus denticornis. J'ai examiné soigneusement la conjonction de ce mando avec la mâchoire, et j’ai trouvé qu'il est fixé à la seconde pièce de la mâchoire, qui forme un petit anneau sur la pièce basale ou stipes. Cet anneau, que l'on peut prendre pour le premicr article du palpe maxillaire, a dans son côté interne un petit appendice capituliforme, qui est situé dans une excavation du mando, et fait avec lui une articulation sur laquelle il peut se mouvoir par ses muscles en haut et on bas comme le mouvement broyant l'exige. Tout près, dans l'cxcaration articulaire du mando, on observe une autre excavation, qui est alongée dans toute sa partie interne et postérieure. Dans cette excavation se fixe un petit style claviforme, qui peut faire avec le mando tous les mouvements quand il est contenu dans le sillon de son côté intérieur. Quand le mando est redressé, ce petit style est caché entre lui et le palpe maxillaire, et c'est pourquoi nous ne voyons pas ce style dans les figures de M. Westrood, excepté dans celle de la mâchoire du Platyrhopalus Melleii, où ce style n'est pas seulement inarticulé mais forme un appendice filiformo biarticulé, et tout-à-fait sem- 
blable au palpe maxillaire interne d'un Carabique ou Hydrocanthare. Les autres parties de la mâchoire forment lo palpe maxillaire."

It is due to Dr. Burmeister to state, that the supposed articulation of this style in Platyrhopalns Melleii, as figured by me in the Entomological Transactions (vol. x. ii. pl. fig. $4 c$ ) is apparent only and not real; my notes state it to lave been a flat slender appendage "which was twisted in the middle, but not articulated. In the other maxilla, I did not discover it in this position, but after removing the maxilla, I found it lying loose upon one of the mandibles." It is the more necessary to make this statement, because Dr. Burmeister, in his comparison of the structure of the Paussidæ and Carabidx, has more especially considered this supposed biarticulated structure, as well as the equally supposed dilated lood-like form of the labial palpi in Pentaplatartlurus, as precisely analogous to the Carabideous and Cychrideous structure. "On mobjectera," he observes, "que le palpe intérieur de Paussides est inarticulé, et le palpe des Carabiques biarticulé; mais j'ai déjà montré que quelques genres des Paussides, comme le Platyrhopalus Melleii, Westw. (qui forme un genre particulier et n'est pas un vrai Platyrhopalus) ont des palpes maxillaires internes tri-[bi]-articulés; et l'on voit que ce même palpe chez le Pentaplatarthrus Paussoides, d'après la figure de M. Westwood, (Linn. Trans. xvi. pl. xxxiii., fig. 7 c) est dilaté en forme de capuchon, ct couvre le mando, * comme dans lẻ genre Cychrus, et les congénères chez les Carabiques."

The interest excited by these singular details led me to reinvestigate the structure of the trophi of Platyrhopalus denticornis, the result of which is before the student in the lower series of figures in the accompanying Plate; and which differ in several respects from Dr. Burmeister's descriptions. Without attempting to refer the basal portions of the maxilla marked in this and the other plates of the Paussidx with the marks * and + to the typical structure of the Coleopterous maxilla, I shall merely observe

* The part which in Pentaplatarthrus D1. Burmeister has regarded as a dilated labial palpus, is in fact the real mando; since there is nothing in $\mathrm{my}$ figure to which lie refers, to indicate a scparation between the part which he cousiders to be the mando, and the basal portion or stipes. Hence two of his proof of affinity between the Paussidx aud Carabide are shown to be intenable. 
that the external outer horny piece in Platyrhopalus, $1 e, 1 f$, $1 \mathrm{~g}$, and $1 h^{*}$, is hollowed out within, being filled with muscle below, and having on its inner face above, a small curved horny piece $\dagger$, which is Dr. Burmeister's petit appendice caputiliforme, which is, however, shown in my fig. $1 \mathrm{~g}$, to lave no connexion with the basal joint of the maxillary palpi $(\ddagger)$ as Dr. Burmeister describes it; its use also as a socket or fulorum for the alternate eleration and depression of the hooked mando, appears to me to be altogether gratuitous; as, although $I$ endeavoured to move it in all directions (see figures $1 h, 1 i, 1 k, 1 l$,) I could not find that it even possessed an independent movement. Indeed, I believe Dr. Burmeister's figure 10 is composed of this small corneous piece $t$, and the true mando ; and that his fig. $8 a$, and the left-hand portion of his figure 10, are the same organs seen in different positions, and that they have no distinct existence in nature. This small piece t, varies in size in the genera of the present family. I find it in Paussus to agree in minuteness with Platyrhopalus. In Cerapterus Hopii (ante, pl. 50, fig. $5 d+$ ) it is much onlarged, and becomes external; and in Pentaplatarthrus ( $\mathrm{pl} .58$, fig. $2 \mathrm{c}$ ) it is very large, assuming the place of the basal part *. The minute exarticulated style appears to be restricted to this genus, it having been only found in P. denticornis and Melleii. It is to Dr. Burmeister that we are indebted for pointing out its analogy with the labial palpi of the Carabideous insects.

The four species represented in the accompanying plate are more especially typical of the group; P. Melleii and aplustrifer receding from its general habit, but yet they are not sufficiently distinct to warrant me in separating them generically. P. lævifrons and dentifrons, as mentioned above, must now be removed to the genus Paussus.

Species I.-PLATYRHOPALUS DENTICORNIS. (Plate 68, fig. 1.)

P. sublatus, rufo-castaneus, elytris dorso fusco; sutura late ad basin, maculaque utrinque postica rufo-castaneis, antennarum clava magna latere omni acuto continuo at juxta basin externe incisione parva distincto; thorace antice utrinque rotundato-dilatato.

Long. corp. lin. $3 \frac{7}{8}$, ad lin. 5 .

Habitat in India Oricutali (Bengalia, \&c.) In Musæo nostro, \&c.

Srn.-Pausus denticornis, Donov. Epit. Ins. Ind. Pausus, No. 1, tab. 5, fig. 1 ; Rees Entomol. pl. 8, fig. 10 and $10^{*}$; sine descript. (ncc Gyllenhal).

Platyrhopalus denticornis, Westwood, in Trans. Linn. Soc. vol, xvi. p. 657, tab. 33, fig. 43-48, vol. xix. p. 50; Burmcistex, in Guer. Mag. Zool. 1841, Ins. pl. 76, fig. 2 , \&c. 
Desen.-Rufo-crstancus, supra subdepressus undique luteo tenuitcr pubesecns, nitidns sub lente tenuissime punctatus. Caput antice depressum margine antico parum elcrato et in medio subemarginato, inter oculos subcanaliculatum canali in parte elc vata postica in impressione profundiori terminato. Palpi rufescentes. Antenna rufo-castancæ artienlo apicali (clavâ) maximo, prothorace majori fere orato, basi tamen subemarginato truncato, supra in disco parum conveso, subtus magis gibboso, marginc owni compresso acuto superne justa basin (ct cum co parallcla) impressioue transversti, qux ad marginem posticum in incisionem parvam et angustam desinit, angulo lasali (dentem formante), externe subrotundato; incisiono interne tamen fere recta, inde apex dentis subobtusus apparct. Prothorax brevis transversus basi apiceque truncatus antiee multo latior ef elevatior, lateribus rotundato-lilatatis juxta rel paulo ante basin, subcmarginatis, ibique depressus, et utrinque foreâ transversa brevi parra. Elytra prothoracis parte antica latiora et illo quadruplo longion, oblongo-quadrata, basi transversiu impresso, rufocastanea, disco nigro plaga magna subtriangulari basali, sutura maculisque duabus posticis ovalibus relictis rufo-cnstaneis. Tibise dilatatre compresse, angulo externo apicali presertim in posticis, acutis, 2-calcaratis. Corpus totum infra rufo-castancum, segmento anali abdominis margine postico rotundato.

Obs.-Fig. 1 represents the insect magnified; I $a$, the antennx of the usual form; $1 b$, the antenna of snother specimen, in tho collection of M. Dupont, where it is incorrectly named by him P1. Melleii ? and which is ratler darker than the ordiuary specimens, but not otherwise distinet, either in structure or markings. I presume this difference in the form of the clava of the antenna may be sexual; at all events, I cannot regard it as a specifie distinction, unaccompanied by other eharacters.

Fig. $1 c$ represents the labrum, I $d$ the naandible, the figure not numbered, to the right of which is the mentum, labial palpi and labium; I $e$ the maxilla scen from below; I $f$ the same seen more from within the mouth; $1 \mathrm{~g}$ the basal portions separated, and basal joints of the palpi; $1 h$ the maxilla with the palpi entirely removed; $\mathbf{I} i, \mathbf{I}$, and $l l$, the mando, and its basal pieee, nnd the maxillary palpus seen in different positions; $1 \mathrm{~m}$ the extremity of the posterior tibia and tarsus.

\section{Species II.-Platrrhopalus Westwoonu. (Plate 68, fig. 2.)}

P. latus, rufo-eastaneus, elytris plaga magna triangularc ad basin alterisque duabus lateralibus, fascia que tenui irregulari ad apicem nigris; antennarum elava magna subrotundata margine postico parum undulato, et rersus basin late incisa angulo exterro aeuto. Long. corp. lin. 4.

Habitat in India Orientali. Mus. D. W. W. Saunders, F.L.S., etc.

Syn.-Platyrhopalus JVestwoodii, Saunders in Trans. Ent. Soc. Vol. ii. p. 84, pl. x., fig. 5. Westwood in Linn. Trans, xix. pl. 51.

Preecedenti latior: rufo-castaneus, nitilus sub lente tenuissime luteo setosus et pnnctatus. Caput antice planum vix cmarginatun linea tcuuissima impressa e margine antico rersus rerticcm extcusa, impressionibus que duabus vis distinctis ad marginem internum oculorum; antennarum clava magua fere rotundata, supra ct infia fere aque convexa margine postico parum undulato, ct versus basin incisione profundiori et latiori denteque multo acutiori armata. Prothorax postice angustior lineisque tribus transrersis vix distinguendis Elytra lata, rufo-castanca ad basin plaga magna communi dilatato-cordata, maculaque magna subtriangulari utrinquc, fasciaque tenui irregulari apicali, nigris. Tibiæ ad apieem emarginatis in deutem externum acutum terminatte. Podex niger nitidus.

Obs.-Fig. $2 a$ represents the lower parts of the moutl in situ (more correctly than in Trans. Ent. Soc. ii. pl. x., fig. $\left.5 a_{-}\right)$ $2 l$ the abdomen seen from beneath; and $2 c$ the tarsus with the emargination of the apex of the tibia.

\section{Species III.-Platyrhopalus angustus. (Plate 68, fig. 3.)}

P. brunneo-castaneus; clytris angustioribus, singulo macula magna laterali triangulari nigra, antennarum clava magna rotundata, subconvexa margine postico continuo at versus basin late incisa, dente acuto armato. Long. corp. lin. 3. 
Habitat in India Oricntali. Neemnck, D. E. T. Downes.

Corpas totum nitidum pareo pubcscens, rufo-castaneum : caput antice vix emarginatum, linea longitudinali vis impressa verticem ferc attingente. Antennarum elava prothoracis magnitudine margino omni acuto ; externo vero prope basin incisionc lata ct profunda dente basali acuto. Prothorax capite paullo latior, lateribus antice rotundatis postice paullo angustior (sc. cordato-truncatus) impressione tenui transversa pone medium. Elytra thorace vis dimidio latiora angulis hnmeralibus prominentibus rotundatis, singulo cum tuberculo ordinario ad angulum posticum externum instructo, rufo-castanca, singulo macula magna triangulari nigra versus medium suturam fere attingente. Abdomeu apice nigro, subtus 4-articulatnm. Pedes eastanei tibiis mediocriter dilatatis, apice oblique truncatis.

This species was collected in the interior of India, at Neemuck, by Assistant-Surgeon E. T. Downes, who informs me that he caught a single specimen in his room by lamplight, laving observed it crawling on his table.

Specifs IV.-Platyruopalus Acutidens.

Sxx,-Platyrhopalus acutidens, Westw. In Lin. Trans. xri., p. 661, pl. xxxiii., fig. 50. Ditto xis., p. 51.

This species was proposed by mo upon an incomplete specimen, preserved amongst the insects brought from Nepaul by Maj.-Gen. Hardwicke, and now in the British Museum, of which the elytra, legs, and abdomen are wanting. The head and prothorax are smaller and darker-coloured than in P. denticornis; the protliorax is proportionably rather longer; the eyes are black; the head rounded and subdepressed in front, and not emarginate; the internal margin of the clava of the antenna exlibits a stronger contraction at the base than in that species, and the incision on the outer edge is much wider; and the basal tooth rery acute. In some of these respects it approaches $P$. angustus; but, until a more complete specimen is obtained, it is impossible to determine whether it be identical therewith or not. The regular hind margin of the clava of the antenna, separates it from P. Westwoodii.

\section{Specles V.-Platyrhopalus unicolor. (Plate 63, fig. 4.) (Copied from Scliönherr.)}

P. latus brunneo-castaneus, antennarum clava magna ovata compressa juxta basin externo incisa ; dente obtuso, prothorace antice utrinque rotundato dilatato. Long. corp. (sec fig. Schöuberri), lin. $4 \frac{1}{3}$.

Habitat in:India Orientali. Dom. Pro. Schumacher.

Sxw.-Platyrhopalus unicolor, Westw. In Linn. Trans., xvi, p. 659, tab. xxxiii., fig. 49. Ditto, vol. xix. p. 50.

Pausus denticornis. Megerle, Illig. Mag. 3, 113, not. (absque descr.) Gyllenhal in Schönh. Syn. Ins. tom. 1 pars iii. Appeudix p. 14. tab. 6, fig. 1. Scbönh. id. p. 19, no. 5. Dalman, Anal. Ent. p. 103, sub Hylotoro Bucephalo.

In Mus. Schönherr, Gyllenhal et Dejenn. 
Totus brunneo-castnneus; supra subdepressus tcnuc pubesens, nitidus obsolete punctatus; caput subquadratum nitidum supra obsoletc canaliculatim et o figua Schönherri, vix antice emarginatum ; antcrnarum clava maxima ferc ovata disco parum convexo, subtus magis gibbosa, in margino extcrno profunde incisa. Prothorax brevis transversus antice multo latior lateribus rotundato dilatatis, ponc mediun cito coarctatus, anterins convexus posterius depressus et striga media transversa abbreviata impressus. Elytra humeris antrorsum promincntibus castanca sub-nitida. Corpus subtus brunneo-eastaneum nitidum. Pedes breviusculi pallidius castanei, valde compressi tibiis dilatatis.

In consequence of the priority of Donovan's specific name, denticornis, I have considered it necessary to give this another denomination, and which has reference to the uniformity of its colour, by which it is distinguished from the preceding species.

The curious leafless plant represented in the plate, is the Indian Utricularia reticulata.

Want of space, in a preceding page, prevented me from giving the following summary of Dr. Burmeister's views of the relations of the Paussidre with the other carnivorous families, which I now add; there will be occasion to refer to it in my observations on the genus Paussus in a future number.

"Les Carnassiers sont Déterminés at Partagés de eette Mlanière.

Coleoplera carnivora seu adephaga.

Mandibulæ arcuatw, cornex, maxillarumque maudones cornci, elongati, sæpissime uneinati, setosi vel ciliati, rarius nudi. Maxillarum galcn, sive palpre maxillares iuternæ, «xpissime filiformes, biarticnlate, rarius uniarticulatx vel nulla. Mcntum transrersum in apice bisinuatum, extus dilatatum; ligula liliera, mobilis, extus stipite corneo suffulta. Femora pedum posticorum connata cum pectore cxtus acuminata; trochinteres pedim fulemntes. Alæ pilosæ, rena radialis cellula transversa in apice terminata.

1. Geolestes. Pedibns ambulatoriis; capite exserto, collo plus miuusve elongato.

1. Antenne 11-articulatar, filiforues, rarins monilifomes rel depressæ versus apicem. Maxillarum galea scuper biarticulata clongata, interdum cucullata, sxpissime filiformis . . . . .

2. Antennæ 2-10-articulatæ, vel omnino depressæ, latæ elliptieæ, vel lentiformes, vel irregnlariter clavata. Maxillarum galen §æpissime styliformis uniarticulata, interdum obsoleta rarius cucullata.

1 Carabila.

2 Pausidx.

I1. Hydroeanthari. Pedibus natatoriis sæpissime compressis ciliatis.

1. Antennæ filiformes, rarius medio paululum incrassatæ vel in apiec depressa. Oculi duo. Maxillarum galea semper biartieulata, filiformis, interdum minuta

2. Anteunæ clarata, primo articulo dilatato, anriculato; maxillarum galea obsoleta vel nulla. Oculi quatuor . . . . . 4 Gyrinidæ." 
(a) 


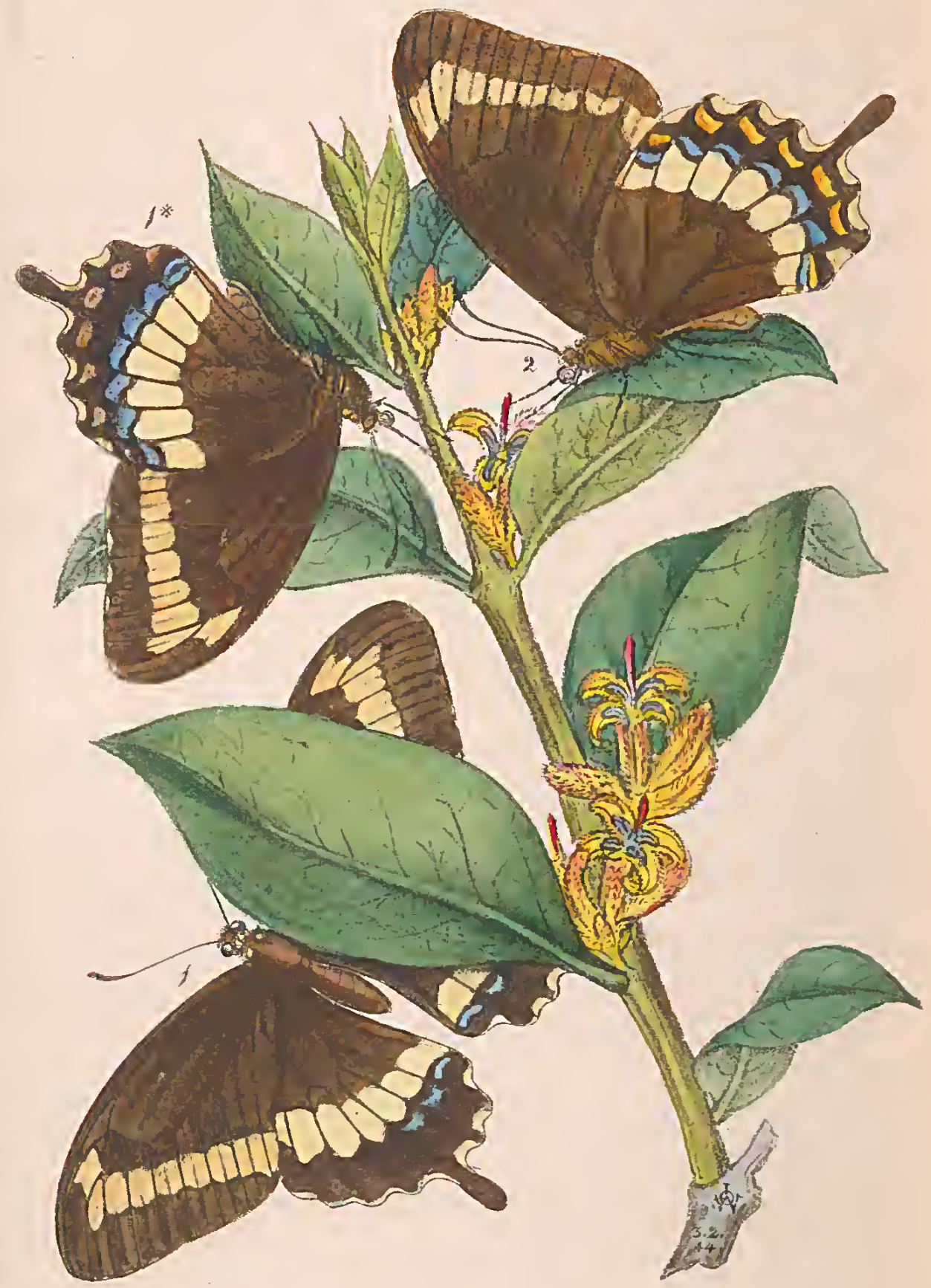


PLATE LXVIII.

ILLUSTRATIONS OF A NEW SPECIES OF PAPILIO FROM MELVILLE ISLAND.

PAPILIO Caxopus, Westwood.

Annals of Nat. Hist., April, 1842.

(Plate 68, fig. 1, and $1 *$, male; fig. 2, female.)

P. alis latis; posticis sinuatis et breviter candatis; incisuris albis, omnibus supra fuscis; anticis fascia sub-apicali e naculis novem albidis; posticis fascia pone medium e maculis septem, lunulâ tenui cæruleâ (puncto fulvo in fœeminâ adjecto), ad angulum ani; alis subtus concoloribus, posticis vero maculis transversis ex atomis caruleis pone filsciam macularem, maculisque vel arcubus pallidis (in fœmina fulvo-tinctis), ante incisuras albidas apicales.

Expans. alar. unc. $3 \frac{1}{2}, 4$.

Inhabits Melville Island, on the north coast of New Holland. In the Collection of the Rev. F. W. Hope, and the British Museum.

This species is most nearly allied to Papilio Pammon, from which it however differs in its considerably broader wings, the fore pair of which are further distinguished by the fascia of large white, or pale buff spots, separated from each other by the dark reins of the wings and by the analogous fascia in the hind wings which runs more regularly parallel with the apical margin of these wings, whereas in P. Pammon, the anterior edge of this row of spots forms nearly a straight line. The disc of the wings, both above and below, is also much less glossed with the minute fulvous scales than in P. Pammon.

The male has the fascia on the fore-wings much more strongly defined than the female, and of a more buff colour. In the hind wings of this sex above, the fascia is followed next the anal angle by a very slender blue lunule, and there are some blue scales forming very nearly obsolete patches behind the next two inner pale spots; on the under side, however, these blue patches are of large size, and distinct behind each of the large cream-coloured spots forming the fascia, the one next the anal angle having a scarcely visible orange lunule behind it. On this side also between the blue patches and the white incisions is a row of dirty buff spots, 
each resting upon a patch darker than the disc of the wing. The female has the fascia of the fore-wings nearly interrupted beyond the middle of the wing, especially on the upper side, the slender blue Innule next the anal margin is sncceeded on the upper side by a small orange transverse spot, and some orange scales resting on a darker brown patch are seeu between the fascia and pale marginal incisions. The extremity of the hind wings is much more varied beneath than above, the white fascia being followed by blue lumules (not so large as in the male), and these by transverse black patclies, bearing buff-coloured lunules: the white incisions are also of larger size than in the males.

The species is named in allusion to Canopus, one of the Southern constellations.

The plant represented in this Plate is the Australian Persoonia ferruginea.

TO A BUTTERFLY SEEN IN MID-IVINTER.

[At the last meeting of the Entomological Society, February 5, 184t, a beautiful specimen of Pontia Rapx, evidently just disclosed from the chrysalis, was exhibited by F. Bond, Esq., which he had captured during the preceding month.]

Child of the Summer! what dost thou here,

In the sorrow and gloom of the weeping year;

When the roses have withered that bloom'd on thy birth,

And the sunbeam that nurs'd thee has passed from the earth?

The flowers that fed thee are frozen and gone-

Thy kindred are perished, and thou art alone-

No one to welcome-no onc to cheer-

Clild of the Summer! what dost thou here?

Yet 'tis sweet thy gossamer wing to view,

Revelling wild in the troubled blue-

Heeding nor rain, nor snow, nor storm-

Buffeting all with thy tiny form.

Even thus the hope of our summer days,

In the heart's lone winter gaily plays-

Thou art the type of that hope so dear:

Child of the Summer! thou'rt welcome here!

Welcome 'mid sorrow, and gloom, and showers,

Emblem of gladness that once was ours-

Emblem of gladness that yet will come,

When the sun-bright ether will be thy home;

And myriads of others, as bright as thou,

Will revel around us-all absent now :

Emblem of hope to the mourner dear,

Child of the Summer! thou'rt welcome here! 


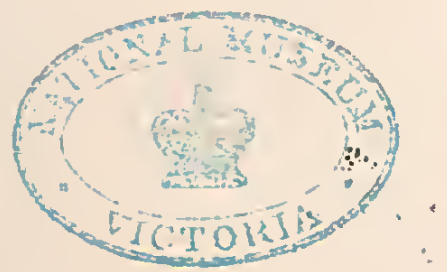

$\because \because$ 


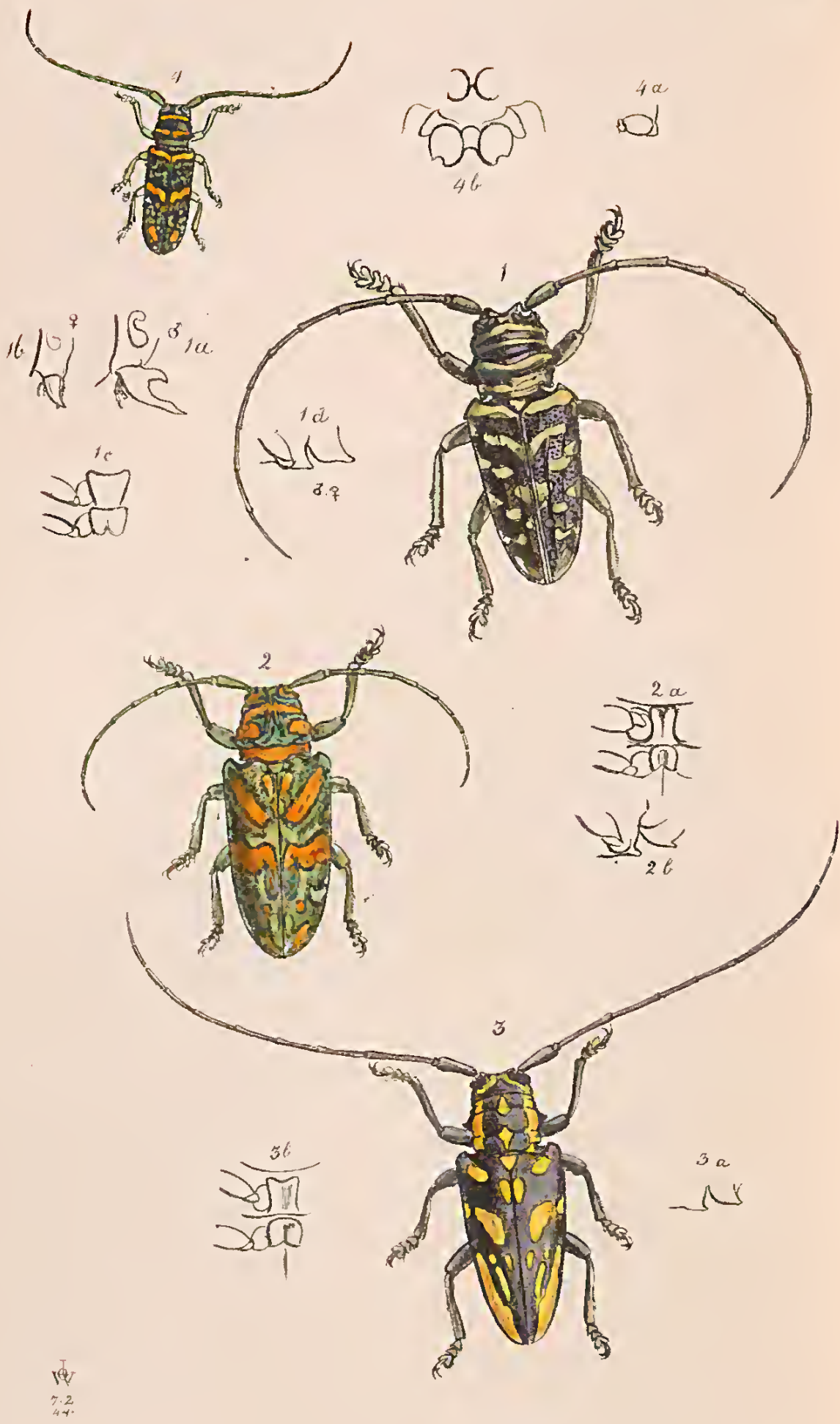




\section{PLATE LXIX.}

\section{ILLUSTRATIONS OF SOME SPECIES OF LONGICORN BEETLES FROM TROPICAL WESTERN AFRICA.}

Tre AfricanLongicorn beetles belonging to the section, of which Lamia regalis may be considered as the type, are amongst the most beautiful species of the entire group; and as our collections are particularly rich in them, I propose to devote a few Plates in the present rolume of this work to their illustration. In the present Plate four new species are represented from the cabinets of the Rev. F. W. Hope, A. Melly, Esq., and my own collection.

The species represented in Nos. 1, 2, and 3, belong to the genus Sternodonta of De Jcan. This group was first pointed ont and characterised by me ten years ago, in a paper published in the first rolume of the Transactions of the Entomological Society of London, having been omitted by Serville in lis revision of the Longicorn beetles. I forborc, however, to propose a separate name for the group, which was subsequently adopted by M. Perchéron, in the "Genera des Insectes," where the name of Sternotomis was given to it, which name must be adopted in preference to that proposed by De Jean, the characters of which were only for the first time published in the "Histoire Naturelle des Animaux Articulés," Vol. III., p. 474 .

The specics represented in No. 4, belongs to the genus Tragocephala of De Jean and Serville.

Species I.-LAMIA (STERNotomis), viRESCENS, Hope MS.

(Plate 69, fig. I, and details.)

L. nigra, æneo-pulverulosa, expite, pronoto et elytrorum basi albo-virescenti fnseiatis, his etiam maculis variis albo-virescentibus oruatis.

Long. corp. lin. 16.

Habitat apud Sierram Leonam.

The head is deeply notched in front, witl a streak down the middle of the face dilated towards the mouth, the labrum, some patches beneath the eyes, and a fascia which runs behind them entirely across the lread, of a pale silvery green colour. The man- 
dibles of the male are large, and each has a strong elevated tooth on the upper side near the base (fig. $1 a$, head of the miale; $1 b$, liead of the fenale); the pronotum is traversed by three slender fascix of the same colour as the scutellum, and a fascia next the base of the elytra is also of the same colour, as well as a number of spots which are so arranged as to form a successive series of much interruped angulated strigx, the points of the angles being directed backwards. All these marks are producerl by a fine silky pubescence; the remainder of the disc of the elytra being black and punctured, the sutural edges, and two slender costæ on each rather elevated, and the sides finely clothed with an æneous powder. On the under side the body is black, and varied with silvery green markings, which mostly form angulated fasciæ, the angles being directed towards the head. The pro- and mesosternums are large, flat, prominent, and truncated in front, in both sexes (fig. $1 c, 1 d$ ). The antennæ of the male are longer than those of the fentale.

Species II-LAMIIA (STERNotoMIS) PALINII, Hope MS.

(Plate 69, fig. 2, and details.)

I. supra omnino pulverosa nigro, glauco, viridi fulvoque raria, pronoti macula utrinque et margine postico, elytris striga obliquâ ex humeris ad medium fere ducta fasciaquc media, fulvis.

Long. corp. lin. 12-15.

Hibbitat apud Sienam Leonam. In mus. D. Hope, Dr. Savage.

The face is prettily varied witl pale green and orange, separated by black lines. The hind part of the head has a black triangular spot (extending on each side behind the eyes), and divided into two parts by a very slender pale line. The pronotum is opaque dull green, with two short black diverging lines extending from the front margin to the middle of the disc; the front margin on each side is orange-coloured, and near each of the lateral spines is a large transverse oval patch of the same colour, edged with a black line; the hind margin is also fulvous; the elytra are dull opake green, witl brighter silvery patches, especially beyond the middle; from each humeral angle nearly to the middle of the suture runs an oblique fulvous bar edged with black, and across the middle is a broad waved bar, also edged with black; terminating next the suture is a reflexed pale green patch. The body 
beneath is fulvous, with the middle of the abdominal segments black and shining.

The sternums (figs. $2 a, 2 b$ ) although porrected, are not near so large as in the last-described species.

SPECIES III.-LAMIA (STERNOTOMIS) AMIENA. Westw. (In Annals of Nat. Hist. October, 1841.)

(Plate 69, fig. 3, and details.)

L. nigra, opaca, pronoto maculis duabus conoideis, lateribusque; maculis circiter 10 (magnitudine variis), lateribusque elytrorum viridi-lacteis ; duabus in medio elytrorum maximis alterisque duabus posticis elongatis et valde angustis.

Long. corp. lin. 11-16.

Habitat in Africa tropicali (Gold Coast), D. Raddon. In mus. Melly et nostro.

This very distinct species has the face black, with a silvery green line running from the inner margin of cach eye nearly to the mouth, where it meets an angulated slender line of the same colour, extending across the lower part of the facc; there is also a small spot of the same colour behind, and another beneath each eye. The entirc sides of the prothorax, except the spines, are cream-coloured; the two spots on the elytra near the base of the suture are nearly connected. The thoracic segments bencath are pale buff, and the abdominal segments black and glossy, with four pairs of round spots of pale silvery grecn, and two other oblong patches of the same colour on the terminal segment. The sternums (figs. $3 a, 3 b$ ), are less prominent than in either of the preceding species, although resembling those of L. Palinii in form.

I am indebted to W. Raddon, Esq., for this and other interesting insects from the Gold Coast.

\section{Species IV.-LAMia (TRAGocePHALA) PUlChELLA. Westw.}

(Plate 69, fig. 4, and details.)

L. supra nigra opaca pronoti marginibus antico et postico guttulisque numerosis elytrorum late viridibus, fasciaque media pronoti, basi et medio elytrorum maculisque duabus apicalibus fulvis.

Long. corp. lin. 8.

Habitat apud Sierram Leonam. In mus. D. Hope.

This lovely insect in its cylindric form agrees with the other Tragocephalæ of De Jean; but from all of these it differs in its colours, which in their contrasts and arrangement rescmble those 
of some of the Sternotomes. The face is green with a slender line of black down the middle; the labrum is fulvous ; the upper part of the head black, with it green margin to the eyes. The antennæ and pronotum jet black, except the basal joint of the former and the front and hind margins of the latter, which are splendid green; across the middle of the pronotum runs an irregular slender fulvous fascia. The body beneath is splendid green with the sides of the metasternum fulvous, and a triangular patch in the middle of the hind margin of each segment, which is black and glossy. The mesosternal process is small and searcely prominent (figs. $4 a, 4 b$ ). 


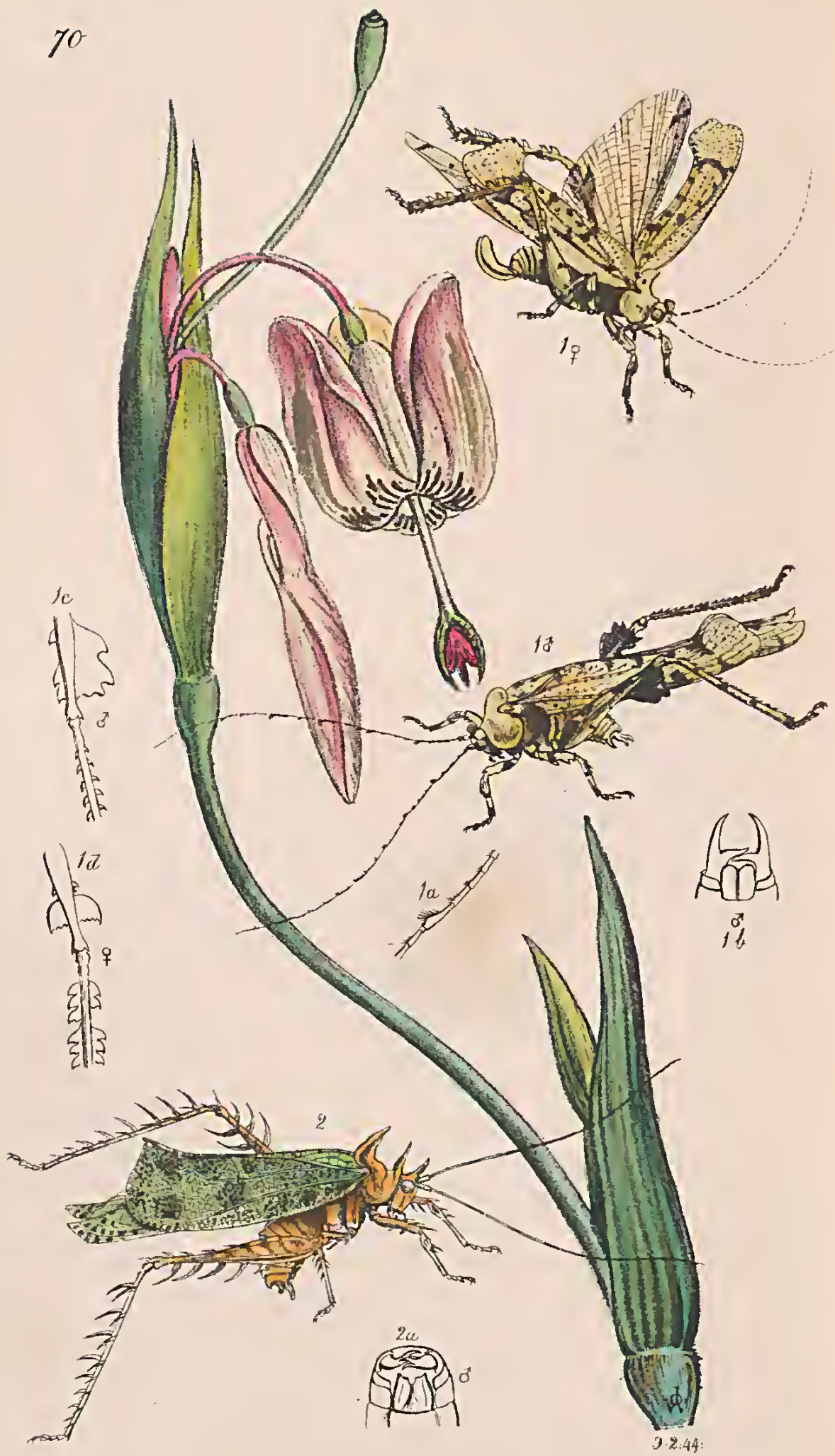




\section{PLATE LXX.}

\section{ILLUSTRATIONS OF TWO NEW SPECIES OF GRASSHOPPERS FROM COLOMBIA AND MEXICO.}

THE insects represented in the aeeompanying Plate are here referred to the genus Phaneroptera of Latreille, with the general structure of which they best agree; they possess, however, such singular charaeters in the spinose and folineeous appendages with which they are armed, and the antennæ in the males of one of them are so eurious, that I presume that they will by some writers be regarded as proper subjeets, requiring the establislıment of distinct sub-genera for their reeption.

\section{SPECIES I.-PHANEROPTERA ALIPES. Westw.}

(Plate 70, fig. 1 of and $1 \%$, and details.)

P. pallide alho-virescens, tegminibus angustis apico intus dilatatis; margine interno nigro maculato fasciaque obliqua paullo nnte apicem, capite inter oculos mucronato, autenuis, in mare saltem, fasciculato-nodosis, femoribus posticis foliis latis subapicalibns instructis. Long. corp. lin. 8. Expans. alar, post. ô lin. 32. 우 lin. 29.

Habitat in Celombia, Mus. D. Hopc, ô ; et in Mcxico. MIus, nostr. + . Communic. D. Parry, F.L.S., \&c.

The eyes are very prominent and globose in this species, ancl between them is an aeute point, more prominent in the female. The antennx of the males are very slender, and appear to eonsist of portions measuring about two lines eaeh, whieh are not eontinuous as in the other speeies, the extremity of eaeh portion terminating in a little dilatation whieh is setose* (fig. 1 a). From what remains of the antenna of my female speeimen, they appear to have been destitute of these nodosities. The face of the female is considerably wider than that of the male, whieh oeeasions a eorresponding dilatation of the lateral margins of the pronotum, whieh in this sex have a small lobe or extension over the fore feet, which does not exist in the male. The pronotum is strongly saddleshaped, the lateral angles of the raised part in the female being more elevated than in the male. The wing-eovers are considerably more elongated in the males than in the females; in both sexes they are similarly marked with blaek spots. The wings are eolourless, except the small apieal portion whieh extends when at rest beyond the wing-eovers. The stermums are simple. The feet are most slender and elongated in the males; they are of the colour of the body, but fasciated or annulinted with blaek; the four

* Dr. Burmeister describes a species from Bahia, with apparcnty similar antennx, l'l. nodicornis (Handb der Lint. ?, p. 689); but the specimen he deseribed (from the collection of lis fatlicr-in.law, ny excellent correspondent, M. C. Soumer, Esq., of Altonit), was a temale, 
anterior femora and tibix, are slightly foliaceous, especially in the female; but the hind femora in the males are furnished near the tips with a large thick black leaflet on the outside, the hind tibix having two rows of serratures (fig. $1 \mathrm{c}$ ), whilst in the female the fomora have two nearly equal-sized leaflets*, and the tibix are furnished with dilated, dentated portions, which give them a very curious appearance (fig. $1 d$.) The terminal ventral segment of the male is emarginate at the tip, and the anal appendages elongated, acute, slightly recurved, and furnished within with a strong tooth (fig. 1 b.) The ovipositor of the female is broad and bent upwards from the base.

\section{SPEeISS Il.-PHANEROPTERA HYSTRIX. Westw.}

(Plate 70, fig. 2.)

P. lutescens eapite spina erecta pronotoque duabus armatis; tegminibns quasi punctatis, apice interno acuto, viridi albido nigroque variis, alis haud coloratis nisi in apicibus; pedibus postieis spinis acutissimis et longis armatis.

Long, corp. lin. 10. Expaus. alar, posticar, liu. 31.

Habitat in Colombia. In mus. D. Hope.

This extraordinary insect has the tubercle between the eyes developed into a strong acute compressed spine, which with two others rising from the pronotum serve to defend the front of the body; these horns have a black line extending along them. The tegmina are varied with pale and darker green with black patches, the veins being elevated and pale-coloured, giving them the appearance of being throughout deeply punctured; the same appearance is also presented by the exterior apical portion of the wings; the anterior femora and tibia liave a few short spines, but the hind feet are armed, both within and without, with long and acute spines, placed at the distance of about a line apart, which decrease in length towards the extremity of the tibix ; these feet are marked with bars of green and black, and the spines of the femora (which are curved) arc black along their front edge. The terminal rentral segment is emarginate, and extends beyond the two anal appendages, which are incurved, pointed, horny, and bifid (fig. 2 a.)

'This fine insect is unique, in the collection of the Rev. F. IV. Hope, F.R.S., \&c.

The plant represented in this Plate is the charming Rigidella Hanmea of Lindley, from Mexico.

* Dr. Burmeister, op. cit., p. 691, deseribes another speeies of Phaneroptera from Rio Janeiro, witl foliaceous black spincs on the lind femora ( $P$. cruenta), also from the collection of M. C. Sommer, Esq. 
(2) 


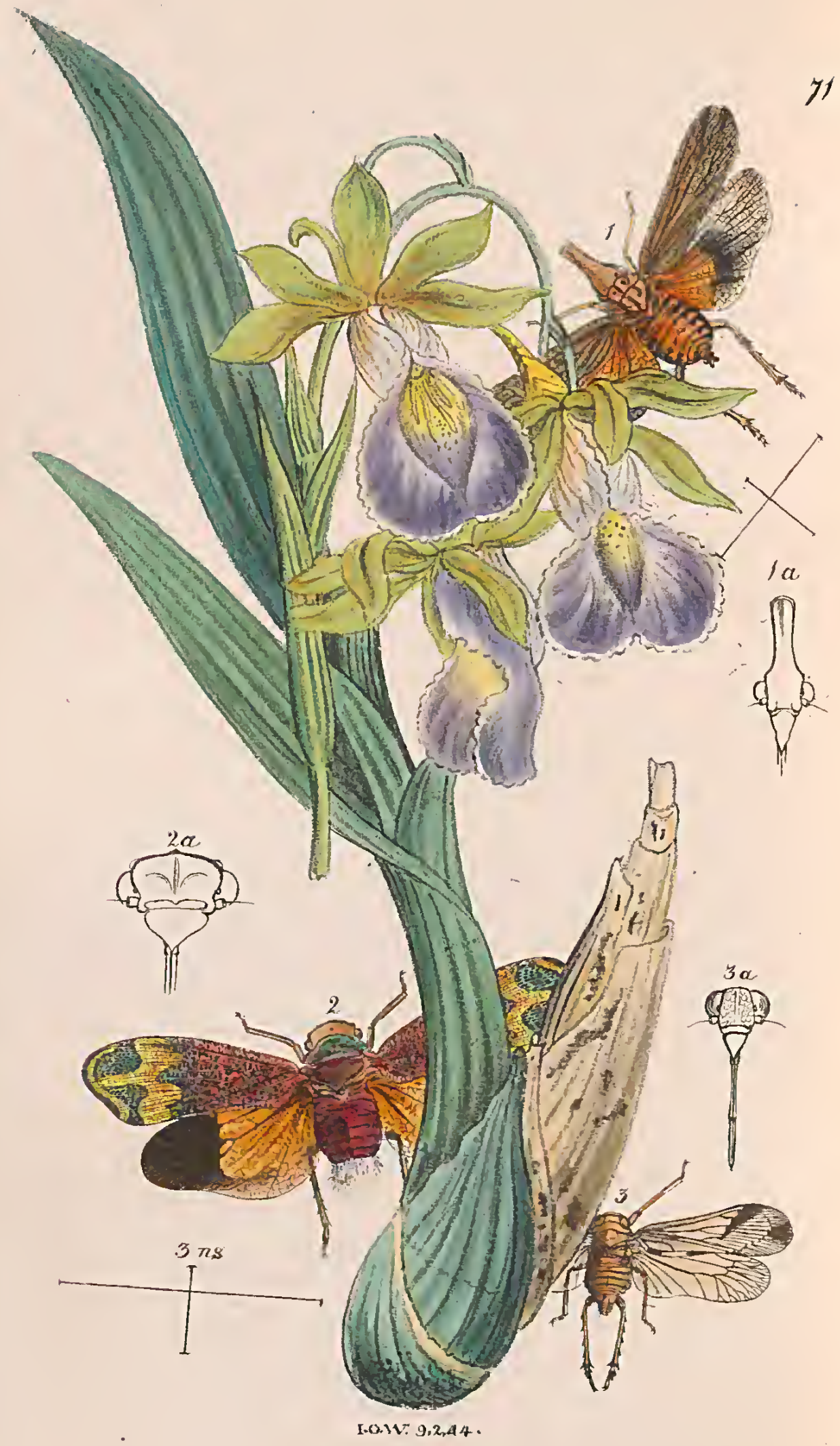




\section{PLATE LXXI.}

\section{ILLUSTRATIONS OF SOME NEW FULGORIDF FROM COLOMBIA AND MEXICO.}

\section{FULGORA (EPISCIUS?) AMIBILIS, Westw.}

(Annals of Nat. Hist., April, 1842.)

(Plate 7l, fig. 1.)

F. rostro (thoracis longitudine, supra plano, subconico apice subtruncato) capite pro- et mesonotis griseu.fuscis, metanoti et abdominis dorso testaceo maculis nigris; alis anticis brunneofuscis apice pallidioribus, fusco-nebulosis; posticis basi fulvis medio fuscis apice byalinis.

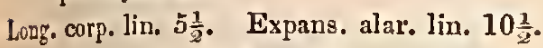

Habitat Mexico. In Mus. Hope et nostr.

This elegant little insect, in its elongated flattened rostrum, agrees with the Fulgora platyrhina of Germar and my monograph published in the Linnaan Transactions, vol. xviii., (which the Narquis Spinola* and M. Serville + have separated as a distinct genus, under the name of Episcius Spinola). It differs from it, however, in its rostrum being more elongated, with both the upper and under surfaces more entire, and especially in the narrow, ordinary form of the fore wings. The structure of the anal appendages is also different. These differences are, probably, in this group, of not higher than specific value; and hence possibly the Aphana corticina of Burmeister (a Brazilian insect, measuring nearly $2 \frac{1}{2}$ inches in the expanse of the fore wings, quite distinct from the Dilobura corticina of Spinola, which measures only 22 lines in expanse), as well as Spinola's species (which M. Serville has named D. Spinolx), and another closely-allied Brazilian insect in my own collection; ought, probably, to be reduced into one group, distinguished by the elongated and flattened rostrum. $\S$ This group is peculiar to the New TVorld, for Homalocephala, the Old World type, (consisting of African and East Indian species, the only other group with a flattened poirected forehead, can scarcely be said to have the

- Ann. Soc. Ent. de France, 1839, p. 252.

+ Hist. Nat. Ins. Hemipt., 1843, p. 494.

+ Dilobura subocellata, Westw. Albido-lutescens fronte subtus subtricarinato et nigromatginato, capite et thorace supra rugosis, abdomine nitido segmentis basi utrinque nigromaculatis, alis anticis albido-lutescentibus fusco subreticulatis maculisque rotundatis luteis, rersus apicem alarum magis indistinctis, alis posticis albis, pedibus supra nigro-maculatis tibiis posticis extus 6-spinosis, spinis apicalibus haud inclusis.

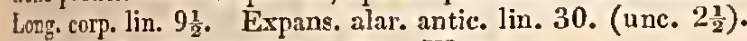

Habieat in Brasilia interiori. Mus. Westw.

Fulgora planirostris of Donovan (Ins. N. Holl.), which Scrville refers to the genus Homalucephala, bclongs to the Cicudellidcous, not to the Fulgoridcous scction of the family. 
rostrum clongated, and it is also distinguished by having the costal portion of the fore wings not homogeneous, and shorter feet.

\section{LYSTRA COMBUSTA, TVEStu.}

(Plate 71, fig. 2.)

L. capite supra obscure caruoso margine antico parm elevato; pronoto obseure virescenti margiue postico tenni fulrescenti, mesothoracis seitello metanotoque et basi ahdominis nigris his sanguineo maculatis ef abiomine sanguineo apice albo floccoso; pedibus castaneo-rufis obscuris, alarum anticarum dimidio basali rufescenti-fulvo, nigro reticulato maculis rotundatis concoloribus, pono medium fascia lata valde undulata et in medio postice angulato lutea; spatio apicali relicto nigro venis viridibus strigaque tenui submarginali Intea, alis posticis fulvis basi sanguineis dimidio apicali fuscis.

Long. corp. lin. 10. Expans. alar. anticar. lin 30 (unc. $2 \frac{1}{2}$ ).

IIabitat in Colombia. In Mus. Hope.

\section{CLADOPTERYX OBLIQUATA, Westw.}

(Plate 71, fig. 3.)

C. Inteo-fusca pronoto et abdomine albido irroratis, apice scutelli et metathoracis albidis, carina mediana abdominis virescenti, alis omuibus hyalinis, anticis fuscia abbreviata triangulari substigmaticali, macula apicali, alterisque tribus rersus basin alarum ad marginen internuru fuscis; tibiis posticis cxtus 5-dentatis: fronte subtus albido-irrotato fascia tenui ad basin labri ad latcra mesosterni utrinque extcnsa, albida.

Long. corp. liu. 52. Expans alar. anticar. lin. 16.

Habitat in Colombia. In Mus. D, Ilope.

The name Cladodiptera, proposed by the Marquis Spinola (Amn. Soc. Ent. de France, 1839, p. 316), being grammatically incorrect, was altered by Serville and Amyot (Hist. Nat. Ins. Hémipt. p. 503), to Cladypha, with the remark that they would have omployed the more correct name of Cladoptera, had it not been already employed by the former of them for a genus of Orthoptera. Such, however, is not the case, as there is no such genus of Orthoptera. I presume that the name Cladoxerus (Serv.) was the one here intended. I have, therefore, retained the name originally proposed, but altering its termination, in order to distinguish it from the ordinary names of the orders of insects.

This species differs from the type of the genus Cl. macrophthalma of Spinola, iu being larger, that measuring only 11 lines in expanse, and in the broad continuous sub-stigmatical spot, the apical cloud, and the position of the spots on the inner margin, towards the base of the fore wings. That species is a native of Brazil.

The plant represented in the Plate is the Orchidaceous Galeandra Baueri, (Batem.) a native of Mexico. 


\section{ENTOMOLOGICAL INTELIIGENCE, NOTICES OF NEW BOOKS, \&c.}

(No. XVIII.)

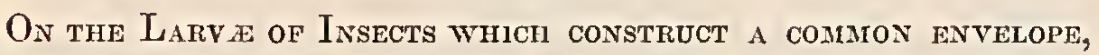
WITHIN WMICH THEY UNDERGO THEIR TRANSFORALATIONS IN SOCIETY.-At the meeting of the Linnæan Society, on the 6th February, 1844, a paper was read by J. Curtis, Esq., F.L.S., containing the descriptions of the nests of two species of Brazilian Hymenoptera. One of these insects belonged to the family Tenthredinidx, and to one of the divisions of the genus Hylotoma, having furcate antenne in the males like Schizocerus, and which Mr. Curtis considered necessary to separate from the rest under the name of Deiloceras. The sexes in this species varied greatly from each other in colour, but the chief interest of the communication consisted in the description of the nest formed by the larræ provious to their assuming the pupa state, and to tho close juxtaposition of the hard cocoons which, in a section of the nest, had very much the appearance of a piece of honeycomb. The outer covering of the mass of cocoons was composed of a thick tissue of threads, spun close together, having very nearly the appearance of the large coverings of the eggs of the Mantida.

This instinct of larve congregating together, and spinning a thick general covering previous to assuming the pupa state and forming their cocoons, is of very rare occurrence; and hitherto no instance has occurred in which the cocoons were so systematically arranged side by side, so as, when cut through, to afford the appearance of liexagonal cells. In the family to which the species described by Mr. Curtis belongs, are found some of the species of the genus Lophyrus social in the larva state, living under a common web, which they quit, however, previous to becoming pupr. The Nematus of the gooseberry, lowever, undergoes its transformations in society, the end of the cocoon of one specimen being attached to another ; * and Messrs. Kirby and Spence mention a still more analogous circumstance occurring in the same family. $\downarrow$ Some of the little parasitic Iclneumonidx, belonging to the genus Microgaster, construct their cocoons in close contact together, so as in

* Mod. Classif. of Ins. II, p. I04.

$\uparrow$ Introd. I., P. 405, 6th Edit. 
fact to resemble the cells in a miniature bee-live.* In other orders I am only aware of this social instinct in the following instances. Reaumur states of the caterpillars of the processionary Moths, which reside in large common tents or nests, "C'est dans leur nid que ces chenilles doivent perdre leur forme et devenir chrysalides;" and that those of the destructive Yponomeuta Evonymella, which reside in a similar web, construct their cocoons "à un des bouts de leur dernier nid." In the first part of the Transactions of the Entomological Society, I published an account of a gregarious specics of Buttcrfly from Nexico, in which the chrysalides are arranged within the nest formed by the caterpillars, and which very nearly resembles that of some wasps; and in my memoir upon the Pomegranate Butterfly of the East Indies, also published in the same Transactions, I described the social peculiarities of that insect, the chrysalides of which are placed in society within the fruit, previous to arriving at which state the caterpillars nust have made their way to the outside of the fruit, and spun the web (probably in common) which supports the fruit to the stem and prevents its falling, and then returned into the fruit. But a much more analogous instance of this socialism was described by me in the ninth volume of the "Magazine of Natural History," in which a mass of the cocoons of the Ilithyia sociella (between two and three hundred in number, if not indeed considerably more) was found in the hollow stump of an acacia-trce. The mass measured about 5 inches in length and $2 \frac{1}{2}$ inches in diameter, the onter covering consisting of a thin layer of floss-silk. I have also secn a nearly similar compact congregation of the cocoons of the honey-moth, Galleria cereana, which feeds in the hive of the honey-bee.

The other insect described by Mr. Curtis was a Brazilian wasp, which forms a long truncated conical nest, similar to those figured by Reaumur, but having the outside of the nest coated with a fine earth or sand. Hitherto those wasps which construct their nests of sand have been found to be only solitary in their habits, not forming regular combs; all the social species which build combs on the contrary being card-makers. Unfortunately Mr. Curtis had not cut his nest open, so that it is impossible to determine the condition of the interior. Such a difference of habits must, however, most probably involve a difference of structure in the man-

* Reaumur Men., tom. ii. pl. xxxv. figs, 7 and 8 ; Mod. Class. of Ins. ii. p. 149, fig. $1 \times x$ i. 17 . 
dibles, maxillæ, and labinm, of which, however, Mr. Curtis gave no account. He also added a summary of the genera of wasps, with which he was acquainted; but all those described by St. Fargeau, in the "Histoire Naturelle des Ins. Hym." were unnoticed.

Wivgs of INsEcts. - "The isolated study of the more important and typical organs of animated beings, though not to be recommended, if regarded only in an organographical point of view, is of no small importance when made the means of illustrating the general principles of natural listory, or its more philosophical inquiries, which can be alluded to but briefly in articles on tribes, genera, and specics. In this way a value may be given to the driest technicalities of the science, which, when philosophically understood, render the strictest descriptive diagnosis suggestive of important and interesting views. Suclı a subject is that of the wings of insects.

"The air is the appointed habitation of the insect tribes, and flight their chief means of motion. The mechanism by which it is effected is not, as in birds, dependent on the modification of certain of the extremities, but on a transformation of the machinery of that organism which las most relation with the air itself-the respiratory system. The wings are metamorphosed gills. The branchire of the Nereids are their prototypes. Thcse again arc processes of the integument. The tegumentary system is characteristic of articulate animals. Among their lighest genera it becomcs their skeleton-an exo-skeleton-which contrasts with the endo-skeleton of the vertebrata. 'The former is the skeleton of the respiratory system; tho latter of the ncrvous system. The former in its most perfect form appertains to creatures which present the highest development of intelligence; whilst the latter perfects itself in motion and the accompanying instincts. According to the relation of their organization to one or the other of theso points, animals are arranged in two parallel series, whicl in themsclves are not simple, but again subdivided into similar and representative groups. The two great series themselves may be regarded as representing the two kingdoms of organised nature-the animal and regetative spheres, as they lave been designated; in the former of which the forms of beings are mainly determined by the influence of their organs of sensation and intelligence; in the latter, by those of respiration and reproduction. If such analogy be true, we should see evidences of its truth on a comparison of the characteristic 
structure in analogous gronps. Such cvidenee we pereeive on comparing the characteristic organs of the members of the vegetable kingdom with those of the mombers of the vegetative (or articulato) sphere in the animal kingdom, of the lcaf witl the wing. There is no finer illustration of the relation of analogy in natural history, than that betwcen the leaf of a plant and the wing of an insect. In both we have a double sheet of eells held together and strengthened by a frame-work of vossels, the structures of tho respiratory system and the processes of the dermato-skeleton supplying the materials in cach. Hence, Oken has well applied to the wings of inseets the name of a ërial gills."Pemy Cyclopedia.

Monographie des E'rotyliess, Famille de l'Ordre des Coléoptères. Par M. Th. Lacordatre. Paris, 1842. 8vo, pp. 543.

This is another of the excellent monographs with whieh the science of Entomology has latcly been enriched by the labours of Continental entomologists. A monograph, illustrated with figures (of which, unfortunately, the present work is entirely deficient), upon this group, was published by M. Duponehel, in 1825, in which 92 species were described. M. Laeordaire, in his monograph, deseribes 570. In an Introduction of 32 pages, the author has given a general account of the characters, habits, affinities, \&c., of the group; admitting that the tarsi are pentamerons, or ratler' pseudotetramerous, the fourth joint being " très-petit nodiforme chez la phupart" (by which character Encaustes, Episcapha, Triplax, and Tritoma, are united to the family); and describing the maxillary palpi as having the last joint " triangulaire, ou en segment de cerele, ou fortement tıansversal, rarement ovoïdc et tronqué à son extrémité" (as in Triplatoma, Dacne). The inner maxillary lobe, in at least half the species, is simple; in a few, it is I-spinose (Encaustes); and in others, bispinose; the teetl long and acute, as in Erotylus and Aulaeocheilus, or vcry short and obtuse (Egithus).

The variations which exist in the lower part of the mouth are very carefully described. The antennæ either consist of a compressed club, suddenly formed, of three joints, or of four joints, gradually dilated. The wings are described as agreeing throughout the group, the difference between those of Encaustes, Triplatoma, Dacne, and Erotylus, bcing insignificant. The Chrysomelidæ have 
wings of a different type, so that the Erotylidx cannot be associated with them. Of the habits and metamorphosis of these insects, but little is lnown. The larva of Agrithus Surinamensis, described by M. Lacordaire, and that of Triplax russica, figured by me, * being the only species hitherto noticed in their early states. The perfect insects reside in boleti, where they undergo their transformations; and, although sometimes found on the trunks of trees, they are never met with beneatl the bark.

The geographical distribution of these insects is peculiar. Of the 570 species, only 65 are natives of the Old IVorld; 505 inhabiting the New World. Can it be doubted, that the immense forests of South America, tceming, as they must do, with the vegetable productions which are the natural element of these insects, are the primary cause of this vast difference? Only three of these insects are, in fact, found iu Asia; 28 inlabit Java; and only two have been received from New Holland (both belonging to the genus Episcapha). Sixteen species have occurred in Africa, and thirteen in Europe. The New World species are thus distributed :-Brazil, 150 species ; Guiana, 130 ; Bolivia, 37; Columbia, 128 ; Mexico, 34 ; the United States, 15 ; the Antilles, $\%$.

Aftcr detailing the reasons which have led the author to unite Erotylus with insects heretofore placed with Engis, he reviews the recent arrangements which liave been proposed, cspecially in this country, for a brealing up of the Latreillian group of Xylophaga, and the proposal of the section Rypophaga; and concludes that the Erotyliens ought to be "tout-à-fait séparées des Chrysomélicns avec qui elle n’a que des analogies très éloignées, et que sa place est dans la section des Rypophaga de MM. Stepliens et Wcstwood"† (probably next Engis or Scaphidium).

The family is divided into two tribes-First, the Engidiformes, consisting of 14 genera, including Triplatoma, Dacne, Triplax, Tritoma, \&c. ; and secondly, the Genuini, also consisting of 14 genera. All these, with their specics, are then carcfully described; and at the end of the volume is a "Concordance Synonymique," in which each of the species described by the chief previous writers on the group is given, with the name and reference by which it is described in the prescnt monograpl. This is a very useful addition : it is

\footnotetext{
* Introduet, to Mod. Class. of Inseets, t. I, p. 39:, fig. 49-6.

+ In my Modern Classifieation of Insects, I suggested that " the Erotylidx ought perhaps to be regarded as more strictly Necrophagous; in which case, the Endomychidre would, I apprehend, be equally liable to removal" (Vol. i., p. 391).
} 
not, however, entirely new, as the author suggests in the Preface; having been adopted by Serville, in his volumes of the Suites ì Buffon.

Upon tite Avatomy of Prilangium Opilio Latr. By Alfred Tuli, M.R.C.S., de. (From the "Annals of Natural History.") London, 1813. pp. 38. With 3 Plates.

The attention bestowed by many of the more recent writers on Entomology, upon the hitherto neglectcd tribes of the Linnæan Aptera, is a circumstance of much interest, the different orders of that class having been at length acknowledged to afford the most valuable assistance in determining the natural classification of the Annulose Subkingdom. It is, therefore, with pleasure that I announce the memoir, of which the title is given at the head of this notice, in which Mr. Tulk has investigated the anatomy, both external and internal, of a very curious group of Arachnidous animals; with which, notwithstanding the extreme abundance of some of the species, our knowledge hitherto has been very superficial. The genus Phalangium, indeed, in their tracheal mode of respiration, subarticulated bodies, and exposed didactyle cheliceræ, constitute one of the primary types of the great class Arachnida, being in these respects intimately allicd to the two other equally anomalous groups, Chelifer and Solpuga ; neither of which have hitherto been satisfactorily investigated. Of the great care bestowed upon this memoir, I am able to speak from personal knowledge, although I am not sufficiently acquaintcd with the minute details of the internal anatomy of these tribes to offer an opinion on some of the results at which the author has arrived. I trust that he will not consider the subject as exhausted, especially as he has not given any account of the early states of these insects.

* These three types constitute the order which $\mathrm{I}$ have termed Adelarthrosomata,-Ent. Text Book, pp. 131, 145. 


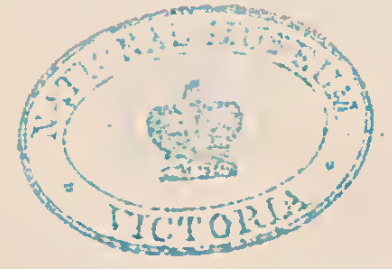

$1 \quad \ldots$ 


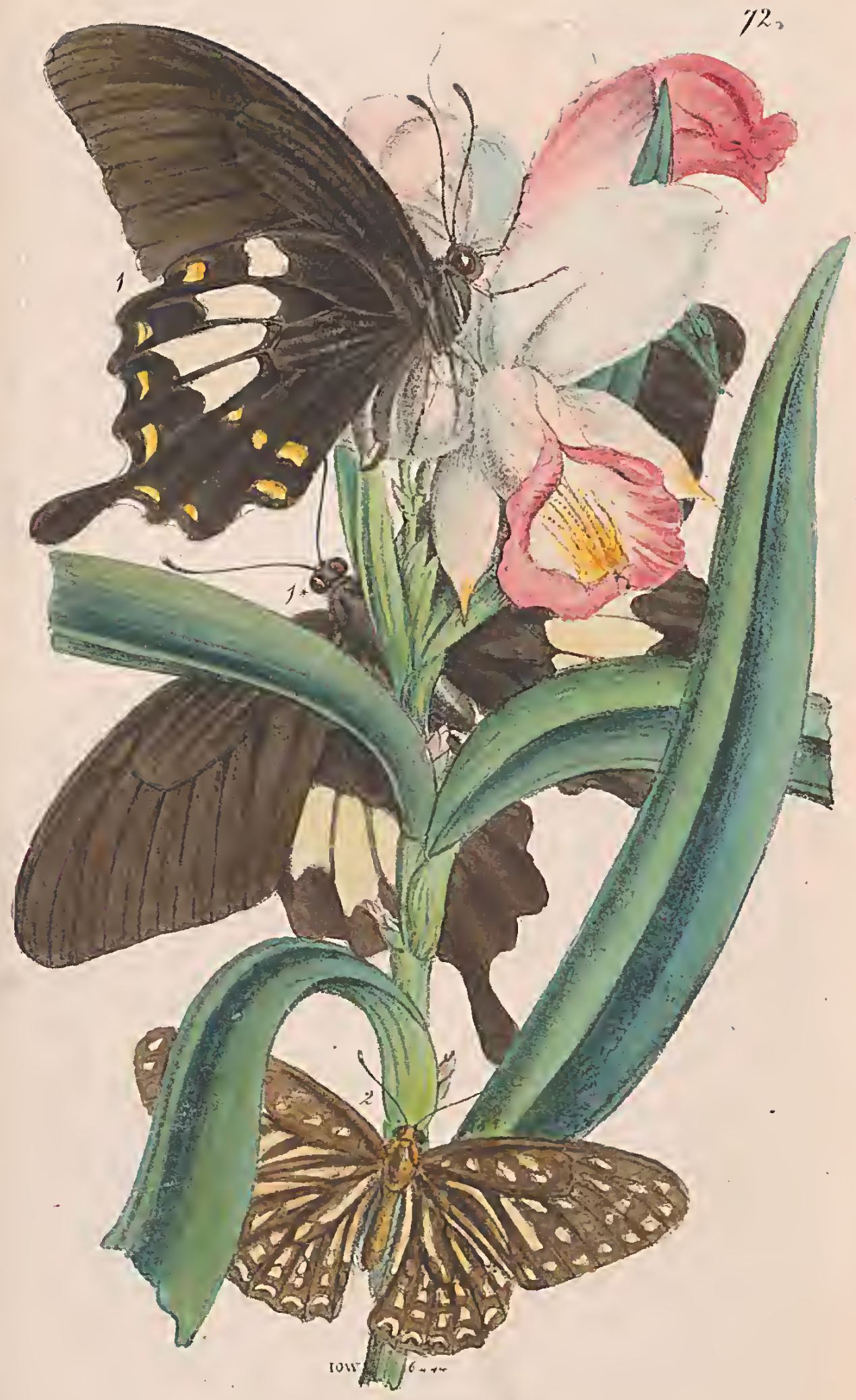




\section{PLATE LXXII.}

DESCRIPTIONS OF TWO NEW ASSAMESE SPECIES OF PAPILIO, RECEIVED FROM MAJOR JENKINS.

The two interesting additions to the genus Papilio represented in the annexed Plate, form part of a collection of insects with which I have been favoured by Major Jenkins, and to whom I beg leave to present the best thanks both of my subscribers and myself, feeling convinced that they will consider that every addition made to our knowledge of the beautiful productions of our distant territories by the zeal of gentlemen resident in such districts, is a subject of congratulation.

PAPILIO CHAON, Westw. Plate 72, fig. $1 \& 1 \%$.

P. alis posticis caudatis; o mnibus supra nigris posticis plaga magná irregnlari 4-partita lactea, anticis subtus ad apicem fuscescentibus, posticis plaga 4-partita alba (ut in pagina supera) naculisque tribus minoribus ad marginem analem extensis, lunulisque submarginalibus luteis incisurisque albis.

Expans. alar. antic. cire. unc. 5. Hatitat in Assam. D. Jenkins. In Mus. nostr.

This species is very nearly allied to P. Helenus a, but differs not only in the form of the pale patch on the disc of the hind wings, but also in the markings of the underside of the same wings. The upper surface of the wings is entirely black, a slightly brown appearance being produced by a few'luteous scales arranged in rows in the discoidal cell, and beyond the middle of the fore wings. The hind ones have a large cream-white patch on the disc towards the outer angle, formed of four confluent spots (the outer one generally hidden by the lind margin of the fore wings); the one nearest the body being oval, the next oblong with the extremity obliquely emarginate, as it is also in the third spot, which is much smaller than the second, and the fourth is still smaller. The fore wings on the under side have a brown appearance, produced by a greater quantity of the luteous scales; the incisures are slightly marked with white; the hind wings on this side are similarly marked with four white spots as above, but in addition to these, there extend three pale luteous lunules towards the anal margin; and there is also a narrow row of the same coloured lunules parallel with the white incisions, which are here more distinct than above.

- It is accordingly named after his unfortunate bròther, Chaon.

No. XIX.-I st MAY, I $\$ 44$. 
PAPILIO MEGARUS, Westw. Plate 72, fig. 2.

P. alis rotundatis, posticis ecaudatis, fusconnigris; albido-strigatis et maculatis lunulisque submarginalibus in alis posticis, alis subtus griseo-fuscis, eodem modo strigatis et maculatis.

Expans. alar. antic. unc. $3 \frac{1}{4}$. Habitat in Assam. D. Jenkins. In MIus. nostr.

This inscct has so little the appearance of a true Papilio, as to cause it to be easily mistaken for one of the Danaides. The arrangement of the wing-veins, however, proves that this is only a relation of analogy, of which several other species also furnish us with examples; especially the Papilio paradoxus, which is a true species of this genus. The present species is most nearly allied to P. Macareus, of the Encyclop. Méthod. (P. striatus. Z. Somm.) The upper surface of the wings is blackish-brown, the basal portions of the rings striated, and the apical portion maculated with whitish marks, the latter forming two rows parallel with the apical margin of the fore wings and the hind wings with a submarginal row of lunules, and without pale incisions; the hind wings are much more maculated beyond the middle than in P. Macareus. The under side is similar to the upper in markings, except that the marks in the discoidal cell of the fore wings are much fainter, and the ground colour of all the wings is a golden greyish brown.

The beautiful plant represented in the Plate is the Orchidaceous Arundina densa of Lindley, from Sincapore.

\section{THE FIRST BUTTERFLY.}

One of the superstitions prevailing in Devonshire is, that any individnal neglceting to kill the first butterfly he may see for the season, will have ill-luck throughout the year. The following recent example is given by a young lady :- "The other Sunday, as we were walking to church, wo met a man running at full speed, with his hat in one hand, and a stick in the other. As ho passed us, he exclaimed, 'I sha'n't hat 'em now, I b'lieve.' He did not give us time to inquire what he was so eagerly pursuing; but we presently overtook an old man, whom we knew to be his father, and who being very infirm, at upwards of seventy, generally hobbled about by the aid of two sticks. Addressing me, he observed, "My $z$ in a took array wan a' my sticks, miss, wan't be ebble to kill 'n now though, I believe.' 'Kill what ?' said I. "Why, 'tis a butterfly, miss, the furst hee'th a zeed for the year ; and they zay that a body will have cruel bad luck if a ditn' 'en kill a furst a zeeth." "-Dorset Chronicle. 


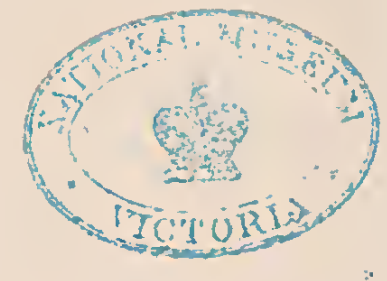




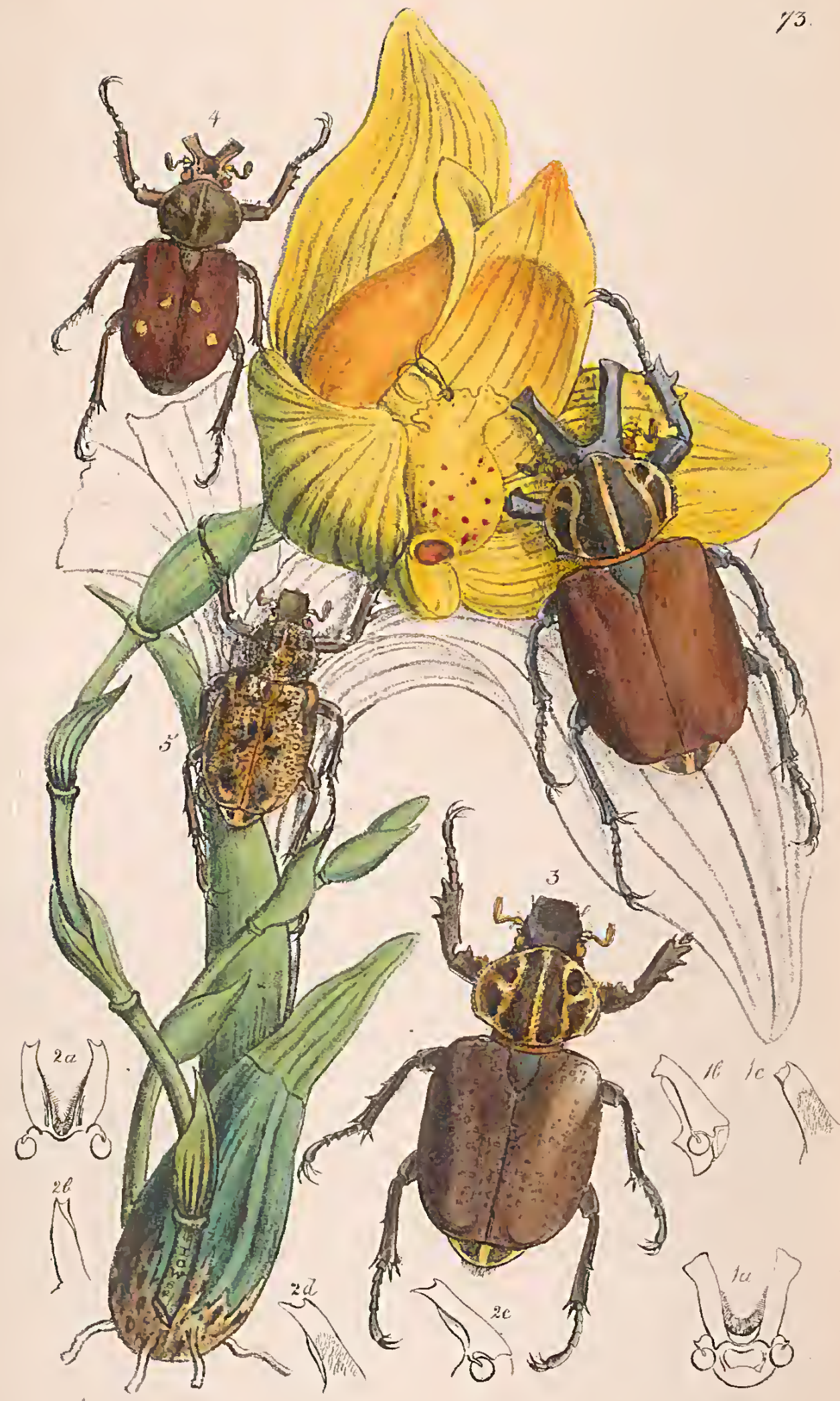




\section{PLATE LXXIII.}

ON TWO SPECIES OF INCA FROM TROPICAL AMERICA.

The Goliathideous Cetoniidæe being (with a single anomalous exception) natives of Africa and India, we may, perhaps, be justified in regarding the species of Inca which are natives of tropical America * as their natural geographical representatives, although they do not belong to the same portion of the family. In respect to their maxillæ, indeed, they form a decided group, having an elongated, cylindrical, toothless galea and.simple mando; thus differing from the Trichiides, which have an obtuse coriaceous galea, and from the Euchiridæ of Burmeister, which have a dentated galea. This author has very carefully illustrated the structure of the trophi in Germar's excellent 'Zeitschrift fur die Entomologie' (ii. tab. 2, f. 5-8, 18).

\section{INCA SOMIIERI, Westw.}

Plate 73, fig. 1 ô, 3 우.

I. chalyboo-niger, supra opacus, pronoto albido vittato et limbato, elytris obscure rufis, albido irroratis; cornubus capitis ô oblique porrecto, apicibus latis oblique truncatis.

Habitat in Mexico-Vilia alta prope Oasaca.

An varietas geograpbica $I$. Weberi ?

Long. corp. ô (cornub. capitis inclus.); unc. 2 ; 우 unc. $1 \frac{5}{6}$. In Mus. D. Sommer.

The two insects represented in Nos. 1 and 3 liave been very obligingly forwarded to me by M. C. Sommer, Esq., of Altona (the father-in-law of Professor Burmeister), with the view of their being figured in this work, if considered distinct from the Cetonia Inca of Weber (Inca Weberi Encycl. Métl., and Burm., I. Fabricii Perty.) The principal difference between the male of the lastnamed insect and that sent by Mr. Sommer, consists in the form of the horns of the head; and as I have found a second specimen, agreeing with Mr. Sommer's, in tho British Museum Collection (arranged with I. Weberi), I have thought it most advisable to give it as distinct from that species, especially as its geographical station is widely different from that of I. Weberi, and as the distinctions between the other species of the genus is but slight.

The head and thorax of the male, on the upper side, are obscure blue-black. The former has two prismatical horns,

- The curious occurrence of a species of this group in Africa must not be overlooked. See Arc. Ent. 1, pl. 46 , f. 6. 
obliquely truncate at the tip, the upper ridge r'unning off to the fore angle. (Fig. $1 \mathrm{~b}$ represents the head of the male, seen from beneath; $1 \mathrm{~b}$ the same seen sideways; $1 \mathrm{c}$ one of the horns, seen within, to show the thick brush of fulvous hairs.*) The antennæ, except the basal joint, are dark fulvous; the prothorax is similar to I. Weberi. The elytra of the male are very dark purplish-brown, with the scutellum and suture greenish, and they,are slightly irrorated, especially towards the suture, with luteous scales. The underside of the body is shining æeneous, with short fulvous pile upon the hind edge of the thighs, and down the middle of the abdomen. The middle tibiæ are curved, and slightly bidentate in the middle, and the hind tibir have a single tooth ncar the middle. The female is darker-coloured than the male, and has the clypeus slightly concave; or rather, the lateral and front edges are elevated: the elytra are much more thickly irrorated with luteous scales. The middle tibire are straight and bidentate in the middle, and the hind tibia have a single tooth in the middle. $\dagger$ The tceth in the anterior tibia are not so acnte as in the female - of I. Weberi.

Note. Perty's figure represents the male of I. Weberi with the horns of the head emarginate at the tip. The figure of the male in Gory and Perchéron's Mon. Cét., pl. 13, f. 1, is unlike any specimen I have yet seen in the form of the horns.

INCA BESKII. Plate 73, fig. 4 ơ, 5 o.

“I. fusco-niger, subtus xnescens fulvo-hirtus supra fulvo guttatus; elytris atro-purpureis; fascia media obsoleta notatis."

Syn. I. Beskii, Dejean; Burmeister.

Habitat "Novo Friborgo ;" Brasiliæ inter. In Mus. D. Sommer, \&c.

No figure of this species having hitherto been published, I am happy to be able to give a representation of both the sexes, by the kindness of Mr. Sommer. There is a specimen, agreeing with the male in the British Museum Collection, with the MS. name biguttata attached to it.

The plant represented in the Plate is the splendid Orchidaceous Maxillaria cruenta of Lindley, from Guatemala.

* Fig. 2 a represents the head of the male of I. Weberi, seen from beneath ; $2 \mathrm{~b}$ one of the horns of the bead, seen from above; $2 \mathrm{c}$ the head, seen from the side; and $2 \mathrm{~d}$ one of the horns seen within.

† The hind tibie in the female (in the Britisb Museum Collection) bave two acute teetb in the middle. 



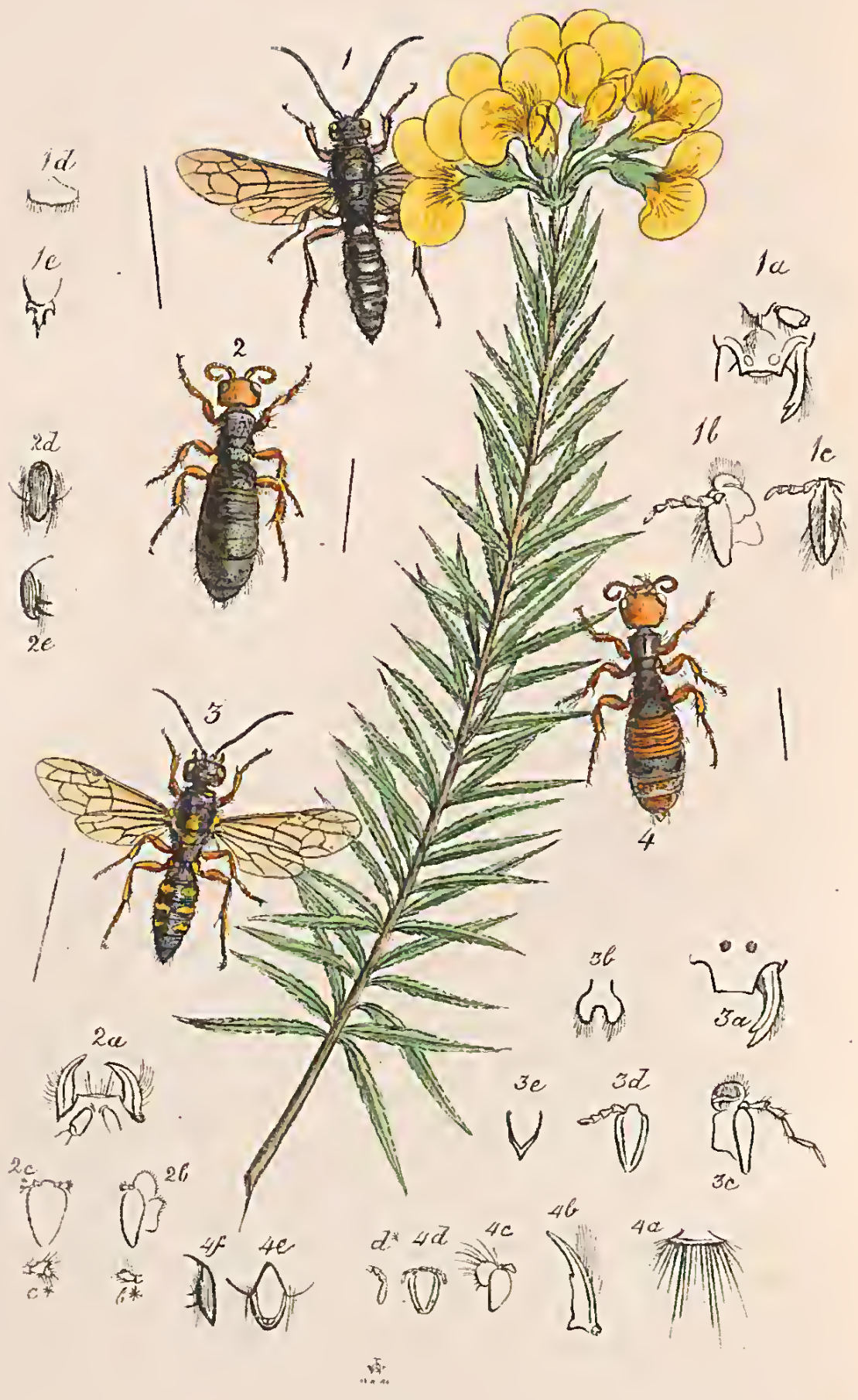




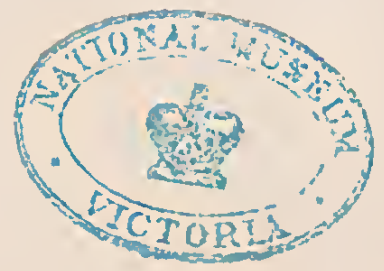


144

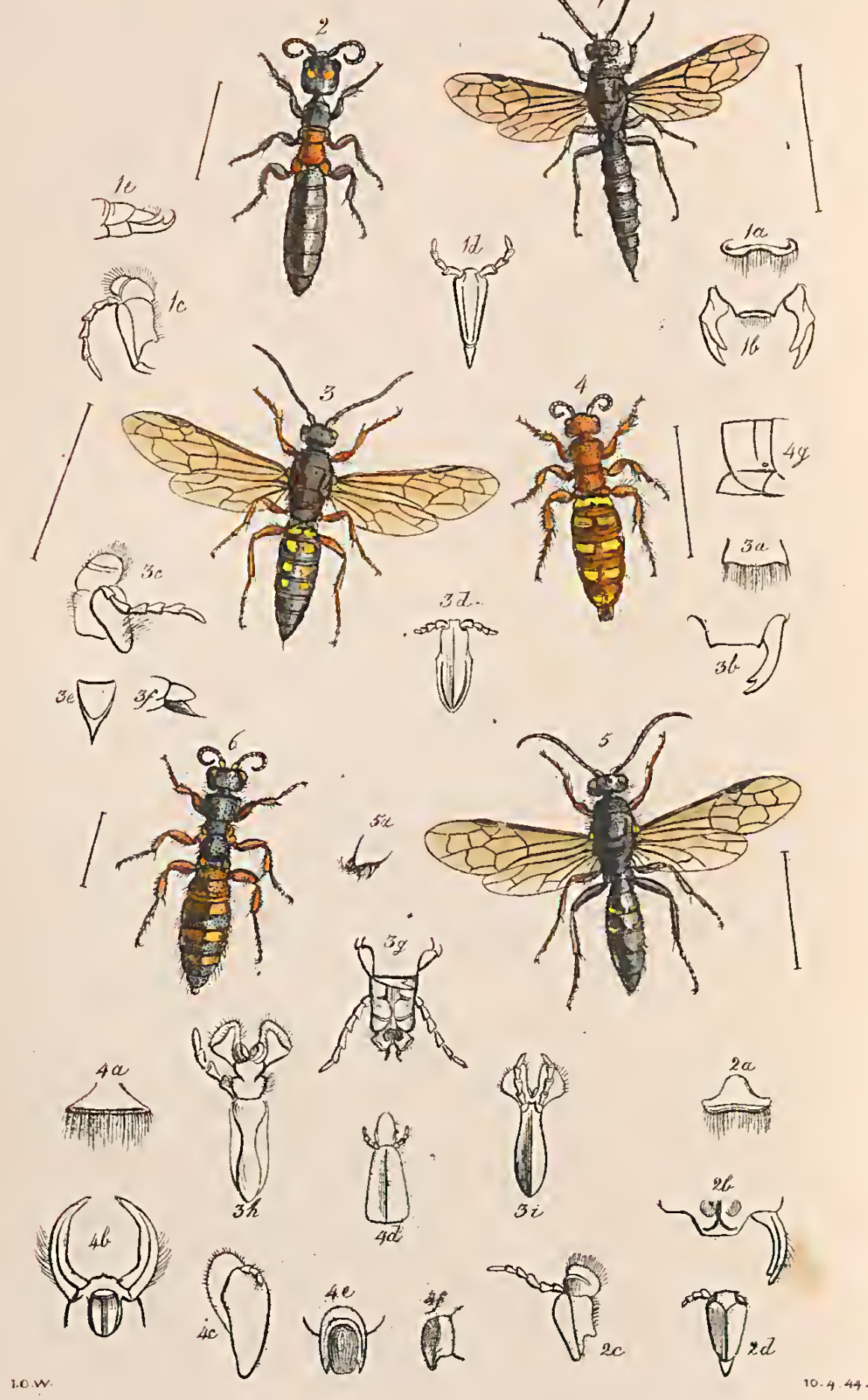




\section{PLATES LXXIV AND LXXV.}

\section{ILLUSTRATIONS OF SOME SPECIES OF AUSTRALIAN THYNNIDEOUS INSECTS.}

THE recent monographs of Dr. Klug and M. Guérin-Meneville upon the Genus Thynnus of Fabricius, and the different results at which these distinguished Hymenopterologists have arrived respecting the generic arrangement of these insects, render the observation of every fact, tending to determine the question at issue, absolutely. necessary; and no one circumstance has hitherto becn shown to be more important than the exact discrimination of the sexes of the different species, since by this means not only are we prevented from forming separate genera for the reception of the two sexes of the same species, but we are thereby enabled to trace the value of the modifications of structure which may have been already, or which ouglit hereafter to be adopted as the characteristics of the several groups into which these insects have bcen or are divided.

As a group, these insects possess an interesting geographical distribution, being only found in Australasia and South America. The species from the latter country are rare in our English cabinets, whilst Dr. Klug describes not fewer than 40 species; whereas our cabinets aro very rich in the New Holland species, which are equally rare in the continental collections.

By the kindness of several friends I am enabled to give representations of both tho soxes of five Australian species.

In order, lowever, to enable such of my subscribers as do not possess the "Voyage de la Coquille," (in the Zoological portion of which M. Guérin publislied lis chief memoir on tliese insects) to enter more effectually upon the consideration of the question of the generic distribution of these insects, I here copy from that work such portion of the tabular synopsis of the genera of the Hymenoptera Heterogyna, as relates to the insects in question.

1. Abdomen des mâles cylindrique, terminé inférieurement par une grande épine recourbée cn haut.

(Genera Methoca, Myzino ct) Rhagigaster, Guér.

2. Abdomen des malles aplati, n'ugant point à l'extrémité d'épine recourbée vers le haut.

a Mandibules tridentées.

* Les deux nervures récurrentes aboutissant aux 2 me et 3 me eellules cubitales. G. Telephoromyia, Guér.

** Les deux nervures réeurrentes aboutissant à la seconde

cellule eubitale. $\quad$ - G. Tachypterus, Guér. 
b Mandibules bidentées, chapéron très-avancé entre les mandibules.

* Labre découvert et saillant.

† Labre bilobé

t+ Labre arrondi.

- Machoires non ciliécs à leur base.

G. Agriomyia, Guér.

oo Machoires très-ciliées à leur base.

G. Thynnus, F.

" Labre rccouvert par le chapéron.

+ Premier cellule cubitale sans appendice.

G. Thynnoides, Guér.

\# Premier cellulo cubitale ayant un appendice.

G. Anthobosea, Guér.

G. Elaphroptera, Guér.*

Rhagigaster, Guér., composed of a single species from Port Jaekson. Rh. unicolor.

Telephoromyia, Guér., composed of a Patagonian specics.

Tachypterus, Guér., consists of a single species, T. fasciatus, from Kangaroo Island, on the const of New Holland. Tho genus is evidently identical with Psamatha (See ante, p. 20), which nause must accordingly sink into a synonyme. Tacbgpterus chalybeus (ante, pl. 54, fig. 5), forms a sccond species in tho genus.

Agriomyia, Gnér., consists of a single specics, A. maculata, from New Hollaud.

Thynnus, Fabricius. M. Guérin describes or notices 18 species of this Australian group. 1. T. dentatus, Fab. 2. T. zonatus, Guér., n, sp. 3. T. variabilis, Kirby. 4. T. affinis, Guér. n. sp. 5. T. obscuripennis, Guér. n. sp. 6. T. rufiventris, Guér. n. sp. 7. T. annulatus. K. 8. T. Australis, Bdv. Voy, Astrol, 9. T. fiaviventris, Guér. n. sp. 10. T. cmarginatus, Fab. 11. T. abdominalis, Fab. $\dagger$ 12. T. integer, Fab. 13. Scolia 7 -cineta, Fab. ?? 14. Tiphia radula, Fab.?? 15. Myrmecodes flaro-guttatus. Latr. (q of T. variabilis?) 16. T. apterus. \& Enc. Mćth. 17. T. pedcstis, Fab. ? 18. T. Grayii, Guér., (Myrmecodes australis, Leacb, Gray, Griff. An. K.)

Thynnoides, Guér.-Three new species, T. fulvipes, Guér.; T. rubripes, Guér. ; and T. pugionatus, all from Australasia.

Diamma, Westiv., (see ante, pl. 54, fig. 6.) In addition to $D$. bicolor, the true type of the genus, MI. Guérin describes a second spccies, $D$. ephippiger, from Kangaroo Island, but it is not congencrous with the former, bcing in fact a female of the genus Rhagigaster. He also suggests that $B$. apterus, Fab., also belongs to the genus.

Anthobosca, Guér.-A singlo epecies from Port Jackson. (Myzene Australasia, Guér. Atlas, pl. 8, fig. 10.)

Anodontyra, Wcstw.-A singlo species from Chili.

Ornepetes Guér. $-A l$ so a single species from Chili.

Elaphroptera, Giér.-Composed of South American species.

Ammodromus, Guér.-Composed of the female of South American species.

In the "Magasin de Zoologie" for 1842, M. Guérin has made numerous additions to our knowledge, both of the species and structural characters of these insects, adding the following new species:-

\section{Rhagigaster homorrhoidalis (Sran River.)}

Agriomyia marginilabris, affinis, Westroodii, abdominalis, and Spinolæ, all from Australasia.

* "Nous n'avons nas fait cntrer dans ee tablenu les deux genres provisoires, Diamma et Ammodromus; ils se composent de femelles qui entreront probablement dans les genres déjł connus, quand on les aura micux observées, et qu'on aura surpris leur accouplement."

+ This species belongs to the family of the bees, and is allied to Crocisa.

₹ Tho cylindric abdomen with a recurred apical spine, unites this species with the genus Rhagigaster of Guer. 
Thynnus Shuckardi, and flavilabris, from New Holland.

Thynnoides nigripes, from Sman River.

He likervise adds the descriptions of two new Australian genera.

Catocheilus, Guér., allied to Thynnus and Agriomyia,-but having a membranaceous concealed labrum, and the termlnal joint of the maxillary palpi very minute, and the maxilles much ciliated within. C. Klugii, Guér., ô $q$. (Swan River.)

Lophocheilus, Gnér.-Allied to Thỵnoides, but having the labrum trnucated and villose in front, slinglly prominent and emarginate, the waxilla slightly hairy, short; Iower lip short, with the paraglossa folded back. 3 Species: I, villosus, L. distinctus, and L.? collaris, - all from New Holland.

Such, with the addition of the genera-

Psamalha Shuckard, mentioned above,

Oncorhinus, Shk, in Gray's Australia Append., Vol. ii., founded upon a fine species from Swan River, and

Amblysoma, Westw. in Guér. Mag. de Zool., founded upon a Brazilian species, and the figure of Anodotyra trieolor, W. published in the same work, constitute the whole of the generic groups hitherlo proposed in the sub-family.

Dr. Klug, rejecting all these generic names, in his Monograph on the genus, recently published in the "Transactions of the Berlin Academy," and uniting the whole under the generic name of Thynnus, has divided the Australian species into three sections,
A. Th. dentatus, \&c.
B. (Agriom yia, Guér.)
C. (Rhagigaster, Thynnoides, and Anthobosca, Guér.);

describing two new Australian species of the section B. (T. variegatus and pulchellus), and also two new species of the section $\mathrm{C}$. ('T. obscurus, and labiatus, Kl.)

At present it is premature to decide upon the propriety of the rejecting of all these gencric groups, although I cannot but think that some of them rest upon characters which will be found to be of too trivial an importance, especially when the general and greatly variable habit of the species is considered; the apparent differences in the formations of the divisions of the lower lip is certainly not to be depended upon in our dried specimens, since in some individuals of a species they are retracted,in others porrected.*

The dissections which I now, however, offer to the student, in connection with those in the 5tth plate, enables us to estimate the value of one of M. Guérin's genera, namely RnaGigaster, whilst at the same time it will serve to show that the females of the Myzine, when discovered, will almost certainly be apterous; the

* Compare pl. 74, fig. 3d. 3g. 3h. 3i. 
female of Rhagigaster differing from those of all the four other species now represented by possessing ordinary-shaped 6-jointed maxillary palpi, like Diamma and Nethoca; from the first of which it is at once distinguished by its depresscd (not compressed) form, and by its nearly simple (not multidentate) mandibles. Notwithstanding these very evident distinctions, M. Guérin has described a fenale of Rhagigaster as a second species of Diamma, as above noticed, and has furthcr increased the confusion by asserting that D. bicolor is the female of Rhagigaster; whereas, there is great reason for eonsidering that it is the female of Tachypterus (Psamatha, Shk.), which has the mandibles more toothed than in the majority of the family, although the female possesses one more tooth than the male, which is not the case in the other specics, of which the sexes have been determined: indeed the contrary occurs in the majority.

The discovery of the female of Myzine will moreover determine whether the surall rudimental vein inclosed within the first submarginal cell of Rhagigaster (which is the only character by which it is distinguished from Myzine $\hat{o}$ ), does not indicate a much more marked difference in the opposite sex than might at first be supposed to be the case, or whether it is sufficient to bind it, as it now does, to the other Thynnideous insects.

The following are the characters of the genus Rlagigaster, as modified and extended by the examination of several spccies, and by the discovery of the female sex, together also with a synopsis of the species which belong to it.

\section{RHAGIGASTER, GUÉRIN.}

ô Abdomen elongatum apice spina recurva armatum, segmento primo subtus tuberculo conico iustructo; segmentis 2 ndo et reliquis ad * basin constrictione subartieuliformi instructis.

Frons inter partem supcriorcm oculorum subcarinatus.

Mandibulæ iutus versus apicem dente armata.

Alx antica cellulis 4 submarginalibus, prima appendiculata.

Palpi omnes forme ordinariz.

Clypcus antice fere recte truucatiss.

Labrum margino antico vix emarginato clypeo fere abscondito.

?. Caput magnum subquadratum planum impressione longitudinali utrinque pone occulos. Mandibula et palpi mari conformes. 'Thorax 3-annulatus, apterus.

Abdomen elongatum depressum segmentis ad basin linea tenui transversa impressis.

* M. Guérin erroncously describos the abdominal segments as having "en arrière, ainsi que le premier une impression transverse.' The lateral examination of the abdomen at once shows that the first segment is not constricted, and that it is the base and not the extremity of the other segments which is thus circumstanced. 
Sprcies I.-Rhagigaster unicolor, Guérin. Voy. Coq. Ins. p. 214.

Niger punctatns piliz albidis indntus, alis antícis hyalinis apice subinfuseatis ; mandibulis simplicibus apicem versus I-dentatis, abdominis apice utrinque dente parro alteroque medio recurvo armato. Long. corp. 19 mill. Expans alar. 30 mill. Habitat, Port Jackson. Terra Tan Diem. Mus. nostr. communic. D. Jos. Hooker.

SPECIES 11.- Rhagigaster ephippiger.

Sys.-Diamma ephippiger, Guérin. Voy. de l'Astrolabe, p. 235. Mag. Zool., 1842, pl. 103, fig. 1-6.

of Niger nitidus antennis, mandibularum apicibus, mesothorace metathorace et pedibus rufis anoque fulvo.

Long. corp. 13 mill.

Habitat. "Kanguroo" insuI. In Mns. Reg. Paris.

Ots.-Hæc est O. Rh. unicoloris, teste D. Shuckard.

SPECIES III.-Rhagigaster mandibularis, Westw. (Plate 74, fig. 1, ठ, fig. 2, 官.)

6. Niger punctatns pilis griseis parum indutus, alis anticis hyalinis fuseo tinctis, mandibulis supra in medio tuberculo conico armatis, abdominis anice spina unica recurva armato.

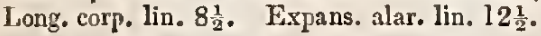

Ots.-Carina frontalis fere indistincta. Spatium constrictum ad basin segmentorum abdoninalium subtilissime punctatissimum.

우 Niger nitidus, capite maculis dnabus frontalibus fulvis, mesothorace metathorace coxisque omnibus ferrugineis, pedibus antennisque nigris. Long. corp. lin. $5 \frac{1}{2}$.

Habitat, Port Philip. In MIus. Saunders et Nostr.

Specifs IV.-Rhagigaster Morio, Westrt. Niger nitidus, punctatus; capite tuberculo transverso supra basin antennarum valde, alteroque supero minus prominenti, mandibulis simplicibus intus apicem versus dente armatis, metatborace supra transverse carinato angulis posticis quedratis, abdominis apice spina unica armato; pedibus rufis, alis nigrican tibus. $\overrightarrow{0}$.

Long. corp. lin. 972. Expans. alar. lin. 14.

Hobitat, in Australasia. In MIus Brit. et Nostr.

Species V.-Rhagigaster hæemorrhoidalis, Guérin. Mag. de Zool. 1842, p. 2.* Niger rugosus, griseo pilosus, segmentis duobus apicalibus abdominis fulvis spina anali recurva nigra 0 .

Long. corp. 15 mill.

Habitat, Ssfan River. In Mns, Guérin.

SPECIES VI.-Rhagigaster integer.

Sxw.-Thynnus integer, Fabricius. Ent. Syst. 2, 245, Kirby, Mon. Ap. Ang. I, p. 223. Donovan. Ins. N. Holl.

Ater, abdominis segmentis margine villoso cinereis, capitis fronte cinereo pubescente scutello truncato ob tuso, ano integro aculco brevi recurvo. of.

Habitat. in Nov. Holl. In Mus. Banks. (Soc. Linn. Lond.)

SPECIES VII.-Rhagigaster binobatus, Westw.

of Niger nitidus, parum punctatus, capito maculis duabus frontalibus fulvis pone insertionem antcnnarum.

Long. corp. lin. $5 \frac{1}{2}$.

Habitat in Terra Van Diemenii. In Mus. Nostr. communic. D. Hooker. Statura Rb. mandibularis, 오 , cui valde affinis coloribus tamen distincta.

- I possess two specimens agreeing with Guérin's description as to colour, but only measuring 5 lines long (instead of 15 mill.), and having no tooth in the basal segment to the abdomen hencath, no carina between the upper part of the eyes, but having five tecth at the extremity of the abdomen, tho middlo one not being recurred at all. I therefore do not consider this insect (which 1 name Thynnus decipicns), as belonging to the genus Rhagigaster. 
SPECIES VIII.-Rhagigaster analis, Westw.

\& Niger nitidus, parum punctatus mandibulis antennisque piceis pedibus scgmentoque apicali abdominis fulvis ; capite pone insertioncm antennarum linea transversa in medio interrupta fulva.

Long. corp. lin. $4 \frac{1}{2}$.

Habitat, apud "King George's Sound." In Mus. Nostr.

Obs. - Mandibula dente interno latiori at magis oblique-truncato nec acuto. Caput minus quadratum, abdomen ad basin paullo angustius longius, segmento ultimo oblongo-ovato.

SPEc1es? IX.-Bethylus apterus, Fabricius. Syst. Piez., 238.

우 B. apterus niger pedibus rufis abdomine piloso nigro segmentorum marginibus ferrugineis nitidulis.

Habitat in Nova Cambria. D. Billardiere.

Obs.-My notes made upon tbe Fabrician collection at Kiel, in wbich the typical specimen is prescrved, state that this insect is a Myrmecodes. Its colours seem to indicate it as a female of this group.

Specirs? X.-Mryzine ruficornis, Guérin. Prodrome d'une Monogr. des Myzinez, p. 11, (Ext. Dict. Pittoresq. d'Hist. Nat. t. v.)

o "Tête noire arec le chaperon ct les antennes faurcs, thorax noir, ponctué arec le prothorax, trois taches sur le mésotliorax et deux grandes tacbes de chaque côté orangées. Ailes incolores, pattes orangécs, abdomen orangé, avec la base des segments noire."

Long. 12 mill.

Habitat, in Arabia!

Obs._Cellula lma. submarginalis appendiculata.

THYNNUS HYALINATUS, Westw.

(Plate 74, fig. 3 of; fig. 4 우.)

of T. capite thoraceque fusco-æneis fulvo dense tomentosis metatborace flavo-vario, abdomine nigro nitido segmentis quatuor prioribus flavo-maculatis, alis fere hyalinis, pedibus testaceis.

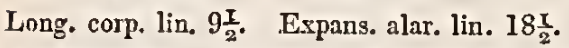

+ Ferruginea albido-pilosa, abdomine magis piceo, segmento 1 mo fascia integra flava, reliquis interrupte flaro-fasciatis.

Long. corp. lin. 8.

Habitat in Terra Van Diemenii, D. Lewis. In Mus, nostro, D. Lewisio amicissime communicatus.

This species is very nearly allied to $T$. variabilis, but it is at once distinguished from that species by its uniform smaller size, the almost uniform colour of the thorax, and the nearly hyaline wings of the male. The head in this sex is æneous black, closely and finely punctured, and clothed with short close fulvous pubescence; the clypeus is yellow, which colour is extended along the anterior and posterior margin of the eyes, higher than the insertion of the antennæ; it forms also a slender branch behind the eyes. The mandibles are fulvous with black tips, the antennæ black and slender. The thorax is slightly æneous black, finely punctured, and tomentose like the head, with a slender transverse yellow line behind the scutellum and the metathorax, with a large patch above 
and one on each side. The abdomen is black and shining, the first segment with a large irregular yellow spot nearly divided in two by a black clavate line; each of the three following segments has two round yellow spots on the back and an oblong one on each side, as have also the fifth and sixth segments; but in them they much diminish in size; the five anterior segments on the under side are varied with yellow spots, which become gradually smaller beyond the 2 nd joint. The legs are castaneous red, the coxæ alone black, the posterior coxa with a yellow spot in front. The anal appendage terminates in an acute point, without any lateral spines.

The female is dark chesnut red on the head and thorax, which are slightly and widely punctured and pilose, the punctures being larger and closer near the insertion of the antenna. The clypeus is irregular with a central point (fig. $4 b$ ), the mandibles are pitchy and entire, the antenne pitchy, the legs chesnut red, the abdomen pitchy red, with five yellow fascix interrupted down the middle and at each side; the intermediate segments on each side beneath have a small yellow spot. The first segment has a slight transverse carinated line near the extremity, the second scgment with one near the base and another near the extremity, the intermediate space transversely multi-striolated; cach of the following scgments has a transverse carinated line ncarly across the middle. The terminal segment of the abdomen is thick, truncate, with longitudinal strixe, and a notch on each side beneatlı (fig. $4 e, 4 f$.)

Figure $3 a$, lnbrum ô ; $3 b$, clypeus and mandible; $3 c$, maxilla; $3 d$, labium; $3 e$ and 3 $f$, extremity of the abdomen. $3 \mathrm{~g}$, mouth of nnother specimen with the trophi porrected; $3 h$, the labium as seen within the mouth; $3 i$, the snme scen beneath.

Fig. $4 a$, the labrum of the female; $4 b$, the front of the bead, with the trophi and mandibles seen from beneath; $4 c$, the unaxilla ; $4 d$, labium; $4 e, 4 f$, terminal segment of abdomen; $4 g$, middle segment of the abdomen, seen laterally, to show tho position of the spiracle.

\section{THYNNUS (AGRIOMYIA) DEPRESSUS. Westw.}

(Plate 74. fig. 5 ơ, fig. 6 ‥)

f T. niger nitidus punctatus griseo pilosus abdomine depresso oblongo-ovato, segmentis 2,3 , et 4 to utrinque lunula tenui albida, pedibus anticis rufis, posticis 4 piceo-rufis femoribus uigricantibus.

Long. corp. lin. 7. Expans. alar. lin. 12.

q Capite thoraco ct basi aegmenti lmi abdominis pnnctatissimis nigris; abdomine nitido punctato lujus segmento 2 do et dimidio basali 3 tii rufis. Antennis piceo-rufis, basi nigris pedibusque rufis.

Long. corp. lin. $4 \frac{\pi}{2}$.

Habitat, King Georgc's Sound. In Mus. Brit.

The male is black, with gray hairs; head and thorax punctured 
and immaculate; antennæe, black and slender; the abdomen is glossy black, depressed, and slightly punctured, with gray pubescence; the second, third, and fourth segments have on each side a small, slender, whitish lunule, diminishing in size. The second and third segments have also a whitish lunule on each side beneath, and the fourth and fifth a whitish dot. The abdomen is entire at its extremity, not pointed, but on each side, near the tip, is a small pointed, and another clavate setose exserted appendage, with a thin pencil of recurved hairs (fig. $5 a$ ). The fore legs are red, and the four hind ones pitchy-red; the middle femora with a black streak behind, and the hind femora black. The fore wings are yellowish-smoky, with black veins; and the hind wings hyaline.

The female has the head, thorax, and base of the first segment of the abdomen black, and very much punctured; the abdomen is shining and setose at the sides; the extremity of the first segment, the whole of the second, the basal half of the third, and the extreme base of the fourth segments, as well as the apical appendage, are red; the remainder of the abdomen is black. The second segment has a carinated transverse line at a short distance from the hinder margin, the preceding portion being rudely punctured, and beyond it the segment is glossy and impunctate. The basal half of the third, fourth, and fifth segments are also glossy and impunctate, and the apical portion of these segments punctured. The antennæ are pitchy-red, with the basal joint black; and the legs are red.

\section{THYNNUS (THYNNOIDES) FUMIPENNIS, Westw.}

(Plate 75, fig. 1. o 2. )

o T. subæneo nigcr luteo-setosus et sublente tenuissime punctatus clypeo fulro, macula mediana alterisque duabus lateralibus obscuris; alis fumosis, pedibus obscure piceo-rufis.

Long. corp. lin. 8. Expans, alar. lin. 14.

o nigra enbnitida capite pedibusque fulvis. Long. corp. lin. 5 .

Habitat, Port Philip. In MIus. Saunders et nostr.

The male of this species is very closely allied to T. obscurus, Klug, and T. rufipes, Guer. (from both of which it differs in its smaller size), and also to $T$. rubripes, from which it differs in the yellow markings of the clypeus, the colour of the wings and legs, and the pilosity of the abdomen, and from Th. labiatus, Klug, it differs in the colour of its wings and legs. It is black, with an æneous tinge, which seems rather produced by the very short close luteous pubescence; and under a lens it is thickly and finely punctured; 
the head is black, with the clypeus convex, its extremity emarginate-truncate, yellow, which colour does not quite extend upwards to the insertion of the antennæ; it also forms a short branch on each side, which does not, however, quite reach the eyes. Down the middle runs a dark mark, which is dilated in the middle into an oval ring, and on each side is a dark spot. The mandibles are yellow, with the tips black; the antenux and thorax are black and without spots, as is also the abdomen; the latter has also the intermediate segments constricted across near the base and apex, and margined with slender luteous hairs; it terminates in a flattened point, which is slightly cmarginate on each side near the extremity, and accompanied on each side near the base by a short spur. The wings are smoky yellowish, and the legs pitchy red. The female is black, with the exception of the head, antennæ, and legs, which are fulvous red. The abdomen is very large and gibbose; the first segment has a transverse carinated line near its extremity, the second segment has a carinated line across near the base, and another near the extremity, the intervening space with about three elevated finer carinated lines; the third segment has a transverse impressed line, at a short distance from the base, the intervening space being excessively minutely and closely punctured, and with another impressed line, which runs close to the apical margin in the middle, but at the sides obliquely extends into the dise of the segment. The fourth segment has a similar line near the apex, but none at the base.

Fig. $1 a$, represents tho clypeus and mandibles of the male; 16 , the maxilla; I $c$, the labium ; $1 d$, the labrum; $1 e$, the extremity of the body.

Fig. 2 , the front of the head of the female; $2 b$, the maxilla, with tbe very minute palpus $b$. $2 c$, the labium, witb the very minute labial palpus $c^{*} ; 2 d$ and $2 e$, the defexed entire striolated extremity of the body.

\section{THYNNUS (AGRIOMYIA) ODYNEROIDES, iWestw.}

(Plate 75, fig. 3, ơ fig. 4. 우)

A Niger faro-varius pronoto carina antica flava metathorace immaculato; pedibus fulvorufis, alis limpidis stigmate rufo. Long corp. lin. 7. Expans. alar. lin. 12.

of fulvo-rufescens thorace, abdominis basi fasciaque lata mediana nigris. Long. corp. lin. 4 .

This species is closely allied to Agriomyia maculata. Guér., but differs in several respects. The head and thorax are black, and very closely and finely punctured; the clypeus is narrowly produced and truncated; it is yellow, with a black transverse mark, and 
terminates above (beneath the insertion of the antennæ) in three red points; in the middle, near the front margin, is a deep impressed dot; the mandibles are black, with the outsides yellow; the two tubercles on which the antennae are placed are red on the inside; the head has a small yellow dot behind, in the middle. The collar has a yellow elevated carina in front, and a small yellow dot at each lateral angle, behind; the metathorax has a large yellow spot in the middle, a smaller one on the scutellum, a short yellow line behind the latter, and a yellow dot on each side, above the insertion of the hind wings; the tegulæ are also yellow; there is also a yellow spot on each side, beneath each wing; the abdomen is black, the first segment above witl two minute yellow dots, the four following with a yellow, elongated, transverse patch on each side, having a notch in front, ncar the side, and having the inner extremity produced into a reflexed, yellow tooth; the basal segment of the abdomen beneath is produced into a very prominent, yellow, conical point; the three following segments bear a large transverse yellow spot (inclosing a black mark), and the fifth segment two minute oblique yellow dots. The legs are fulvous red, and the wings hyaline, slightly tinged with yellowish, with a chesnutcoloured stigma; the abdomen is terminated by an oval, flattened plate, with the tip acute.

The female has the head fulvous red, considerably dilated in front, impunctate, with dark fulvous antennæ and mandibles, the latter black at the tips; the thorax is black and punctured, the anterior division longitudinally channelled; the abdomen is fulvous red, with the base and middle black. The second segment has three strongly carinated lines across the middle; the third and fourth have respectively an impressed line across, near the base, and another (bi-emarginate) towards the apex. The legs are fulvous, very much ciliated, and the coxæ are darker coloured.

Fig. $3 a$ represents the front of the head of the male; $3 b$, the bilobed labrum; $3 c$, the maxilla; $3 d$, the labium; and $3 e$, the extremity of the abdomen of the male.

Fig. $4 a$, the very deeply ciliated labrum of the female; $4 b$, the mandible ; $4 c$, the maxilla, with its very minute palpus; $4 d$, the labium, with its palpus $d *$.

The plant represented in Plate 75 is the Australian Dillwynia ericifolia. 


\section{ENTOMOLOGICAL INTELLIGENCE, NOTICES OF NEW BOOKS, \&.}

(No. XIX.)

Monograpita Generis Rhapdidiz, Linnæi. Dissertatio Entomologica. Auct. G. Th. Schreider. Vratislav, 1813, 4 to, 99 pages, 7 plates, coloured and plain.

THis is one of the most elaborate monographs whieh has hitherto been published upon a single genus of small extent, containing only seven species; the author liaving given in great detail the bibliographical history and minute external anatomy and natural history of the speeies in all their stages, as well as very long deseriptions of eaeh of the speeies. In the first of these partieulars he has earefully noticed all the works which have appeared upon this genus up to the present time. In the seeond respeet, he has made great use of the arrangement and modification of the veins of tho wings, and has elueidated several questions not previously determined with preeision-sueh as the existenee of the six or seven eyelets on each side of the head of the larve; the five-jointed tarsi of the imago ; the eurious mode in which the head of the pupa is detached from the skin of the larva. He has, however, ornitted to trace the precise strueture of the divisions of the lower lip of the imago; neither in his magnified figures of the maxillæ are the parts of which they are composed attempted to be traeed. The peeuliarity in the metamorphoses of these inseets which I pointed out in my Mod. Class. of Ins. (rol. ii. p. 58), that the lind feet of the pupa, during its inaetive state, are partially eovered by the wings, is not represented amongst the figures which he gives of the pupa, in all of whieh (although ropresented in the quieseent state) all the legs are figured as free. The appendages at the extremity of the body of the male, hitherto undescribed, have not been repre. sented in the necessary detail. The predaeeous habits of the genus have long been known; the following is Sehneider's aeeount of the mode of attaek:- " Rhaphidia quum vivum inseetum prope se eonspieit, prothoraee sursum flexo, capite deflexo; statim mandibulis impetum facit. Quum insectum se movet subito Rhaphidia regreditur ; inseeto autem debili vel jam mortuo rapide mandibulas eorpori immittit idque perforat aride partium mollium lumorem sugens," p. 42. Of the habits of the larvæ he states, "Larvæ in fissuris cortieis arborum sæpius etiam sub eortice vetusta atque inter 
truncum ipsum et corticem habitant. Totam por æstaten et initio auctumni in corticis arborum fissuris ambulantes adscendunt et descendunt ut victum quærant idque præcipue quod Stern observavit hora meridiana cæloque sereno." In this state they are very pugnacious, destroying and devouring each other, but appearing to prefer the Diptera for food on account of the greater softness of their bodies. The following observations on the reproduction of the limbs in these insects are of great interest, as the genus from the subquiescent state of the pupx may be deemed to hold an intermediate station between the insects which undergo an incomplete and a complete metamorphoses-no instance, so far as I am yet aware, having hitherto been observed in which insects having a complete metamorphosis have been found to possess the power of reproducing their limbs.

"Interdum in exuviis corporis læsæ partes restituuntur sic larvam cujus pes anterior et antenna morsu alius larræe in una eademque arcula asservatæ articulo ultimo spoliata erant, ante ultimas exurias has partes recipere vidi. Læsiones vero post ultimas exuvias præsertim graves, et qua breve tempus ante evolutionem in nymplam accipiuntur plerumque mortiferæ sunt et unicum tantum animadverti casum in quo larva licet amissa post ultimas exuvias dimidia antenna in nympha et imaginis statum transiit sed antenna illa lasa dimidiata permansit et in nympha et in imagine." p. 49. These larvæ both for hybernation and pupation " in arborum cortice cava orata erodunt-Procul dubio hac re in errorem indutus ost Waterhouse (Trans. Ent. Soc. vi. p. 1.), larvam xylophagam esse opinatus est scobes ligni cohærentes vel conglutinatas pro excrementis habens qua vero quod satis expertus sum, speciem habent granularum minutarum forma oblonga colore nigro."

Adopting $\mathrm{my}$ family Mantispidx as distinct from Rhaphididx, the author gives the following distribution of the two groups:-

Fam. Rhaphideodza, prosterdo postico, pedibus omibus homonomis, \&e.

Fam. Mantispiodes, prosterno antico, pedibus anterioribus raptoriis, \&c.
Capite obovato, occllis 3 , prostcrno triangulari alarum costis (pilosis), radialibus cubitalibusque in ramulos dichotomos exeuntes.

Gen. Rhaphidia, Linn.

Capito quadrato, ocellis o, prosterno libero elongato, alarum ramulo unico radiali in furcam exeunte pedibus abbreviatis.

Sub-Gen. Inocellia, Mibi.

Mantispa crassicornis, Schum.

Ocellis o, \&c., Gen. Mantispa.

Vertice ocellis instructo, \&c.,

Sub-Gen. Anisoptera, Mihi; seu Mantispa notha, Erich. 



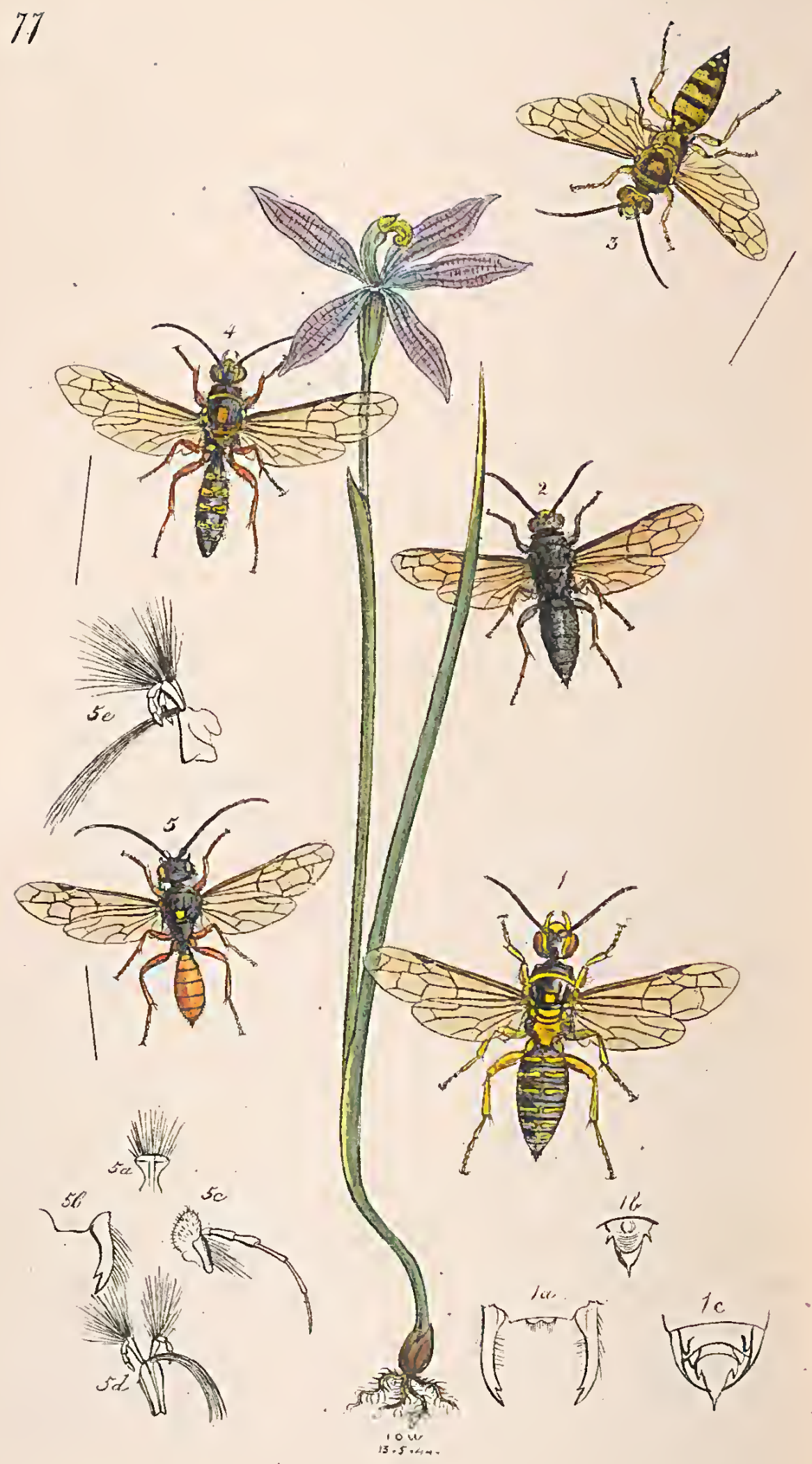




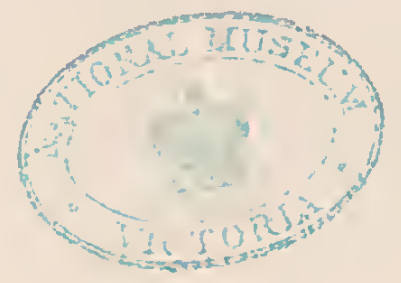




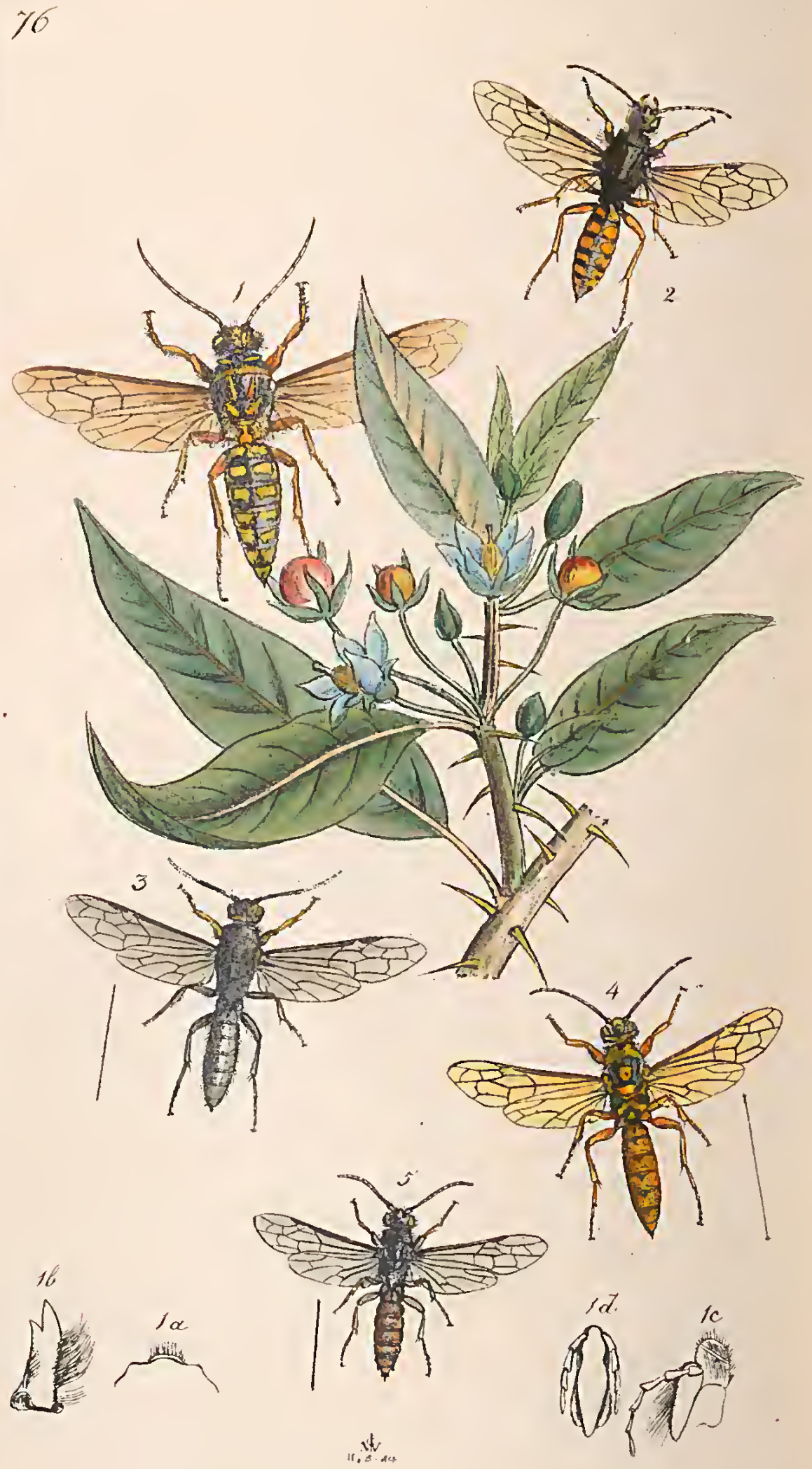




\section{PLATES LXXVI AND LXXVIT.}

\section{A DECADE OF AUSTRALIAN THYNNIDEOUS INSECTS.}

Havisg obtained, since the publication of the preceding number of this work, a considerable number of new species of Thynnideous insects from Anstralia, I hasten to illustrate some of the more conspicuous, confining myself hero to those of the male sex, not deeming it advisable to describe the females as distinct species, which may probably prove to be the opposite sexes of individuals now illustrated.

THYNNUS BROWNII.

(Plate 76, fig. 1 and details.)

T. niger capite et thorace opacis, fulvo tomentosis et maculatis; abdomine flavo maculato, segmento ultimo omnino flavo, antennis longis apice gracillimis, pedibus castaneo-rufis $\hat{o}$.

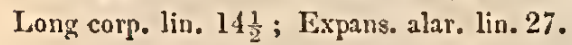

The head is black above, fincly punctured, and clothed with fulvous pubescence, with a slender yellow streak behind each eye, and two small triangular yellow dots belind the ocelli; the clypeus is prominent, convex, and yellow, the cxtremity terminating in a semicircular curve, not cntircly conccaling tho ciliated labrum. It is yellow, which colour ascends in an oval patch as high as the base of the antennie, where it is marked with a black line, which terminates in a conical chesnut-coloured central spot. The margins of the cycs and the tubercles on which the antenne arise are also yellow. The mandibles are yellow, with the tips of the two teeth brown; bencath they are clothed witl a very thick brush of black hairs; the sides of the basal part of the maxilla are also clothed with numerons long hairs. The maxillæ and mentum (except at the base), as well as tho palpi, are fulrous. The antcnme are long (measuring rather moro than eight lines in length), and gradually attcnuated from the middle to the apex, where they are very slender ; they are entirely black. The thorax is obscure black, and very finely punctured, and also very thickly clothed with short fulvescent pubescence, which becomes longer and greycr upon the metathorax. The collar has the anterior margin forming a slender raised edge, which is ycllow, but slightly interrupted in the middle: the hind margin is broadly fulvous; the dorsum is marked with four inpressed longitudinal lines 
between the middle ones, being marked with two posteriorly convergent fulvous conical spots; the scutellum has two large obliquely oval fulvous spots, one on each side, behind which are two slender fulvous transverse strigr, and the metathorax is marked near the insertion of the abdomen with a yellow spot. The scutellum is not conspicuously elevated, and the metathorax is deflexed; the sides of the metathorax are marked beneath the insertion of the wings with two yellow spots, united below by a very slender curved yellow line, and the sides of the metathorax are also marked with yellow. The abdomen is considerably elongated and ovate, being rounded in front, very convex above, and with the apex deflexed or incurved; it is black and shining; the first segment marked above with two small yellow spots at the base, followed by two rather broad transverse yellow spots, which nearly meet in the middle, each spot emitting a minute tooth behind; each of the five following segments is marked abore with two transterse subquadrate yellow spots (each emitting a little tooth behind), and with a yellow spot on each side, the posterior edgo of which extends a little distance along the hind edge of the segment: the serenth segment above is longitudinally striated and yellow, with a small black dot in the middle; the abdomen is yellow beneath: each segment, except the first and last, marked with a brown spot in the middle, and a black curved line on each side. The anal segment beneath terminates in an acute black point, the sides at the base being dilated. The legs are castaneous; the coxæ yellow, marked with a small black spot at the base. The wings are stained yellowishbrown, with the costa darker ; the hind wings paler coloured.

From King George's Sound. In Mus. Brit. et Westw.

I have adopted the MS. name applied to this species in the British Museum collection, in which a single specimen is contained.

Figure $1 a$ represents the front of the clypeus and labrum; $1 b$, one of the mandiblcs; $1 c$, a maxilla; and $1 d$, the meutum and labial palpi.

THYNNUS PICIPES, Westw.

(Platc 77 , fig. 2.)

T. niger capite et thorace griseo pubescentibus, clspeo mandibulisque flavis, pedibus nigris, tibiis et tarsis brunneo-fuscis, alis fiavido-fuscis, costa nigra.

Long. corp. lin. $10 \frac{1}{2}$. Expans. alar. lin. 19 t.

An varietas T. flavilabris, Guérin Mag. do Zool. 18.42, p. 8 ?

The head is black, slightly shining, finely punctured, and clothed with short grey pubescence. It has a bifid tubercle in the middle 
of the face, at the sides of which the antenne are affixed; these are short (four lines long), filiform, and black. The clypeus is rather prominent, oval, convex, and yellow, with the lower margin truncate, and nearly concealing the labrum; the mandibles are slender, yellow, with the tips brown, the underside sparingly furnished with long hairs. The maxillre, mentum, and palpi, are pitchy-black; these do not differ in structure from the dotails of fig. 1, except that the maxille are more slightly furnished with hairs at the sides. The thorax is entirely black, and finely punctured; it is elothed with short gray pubeseence, both above and beneath, the metathorax bcing more thickly covered with longer white woolly hairs; the wing-scales are black, as is also the abdomen, which is long, obconical-ovate, and finely punctured, each segment having a stronger row of punctures near its posterior margin; the terminal joint bencath is prominent, deflexcd, transversely striated, and produced into an acutc point at the tip, each side at the base being dilated into a small conical tooth; the basal segment beneath is carinated down the middle. The legs are black, with the tibire and basal joints of the tarsi pitcly-brown, elothed with finc grey pubesccnce, the tibix being slightly rugose, the tarsal ungucs are fulvous at the base. The wings are stained with yellowish brown, which is deepest coloured in the marginal and first submarginal cells. The costa is black.

Inlabits King George's Sound. In Mus. Westw.

I should have considered this to be Thynnus flavilabris, wero not that species describcd as liaving the pubcscence of the head and prothorax "d'un jauno fanre," the legs as cntircly black, except the calcaria and tarsal ungucs, and the size much exceeding that of $m y$ insect, being twenty-six millemetres, or thirteen lines, in length.

\section{THYNNUS INTERRUPTUS.}

(Plate 77 , fig. 1, and details.)

T. niger lavis, capite thoraceque flavo-variis, abdomine fasciis sex tenuissimis flavis, medio interruptis, pedibus fulvis $\hat{\delta}$.

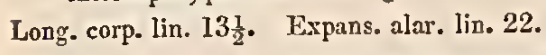

The head is very finely punctured, and black, with a small yellow $V$ like mark in tho middle of the face, beneath which, on each side, is a deep black excavation, within which the antennxe are affixed; the clypeus is large; prominent, yellow, and shining, produced into a conical point above, and with the anterior margin straightly truncate, nearly concealing the labrum (fig. 1 a), which 
appears to be bilobed. The eyes are margined with yellow. The mandibles are long, slender, and yellow, with the tips brown, the inner edge very slightly setose. The maxillary palpi are broken in my speeinen. The antennæ are short, filiform, and black. The thorax is robust, black, polished, and very finely punctured. The prothorax has a very slender yellow raised anterior margin, interrupted with black in the middle; the posterior margin is more broadly margined with yellow, whieh extends only to the wingscales, which are also yellow. The metathorax is marked with four deeply-impressed lines, having a yellow spot in the middle. The scutellum is black at the base, with a broad yellow lunule, with a separate yellow spot at each side; near its anterior angles, belind the seutellum, is another slender yellow lunule, and two lateral yellow spots, and the metathorax is nearly occupied by a large angulated yellow spot, which is narrowed behind; its lateral edges, which are very prominent, being also yellow; each side of the mesothorax is marked with two yellow spots beneath the base of the wings. The abdomen is elongate-ovate, convex, black, very finely punctured; each of the six anterior segments with a slender transverse yellow fascia across the middle, interrupted down the centre of the abdomen; the penultimate joint beneath is armed with two prominent tubereles (fig. $I c$ ), and the terminal joint is elongate, lanceolate, the tip acutely pointed, and the base on each side pro-; duced into a short point (fig. 1 b). The intermediate segments of the abdomen beneath are fulvous, with a slender interrupted transverse fascia on the hind margin. The legs are fulvous; the anterior coxæ large, flat and yellow; the inner edge produced into a narrow piece, which at first sight appears distinct; the mesosternum is also produced behind into two yellow points, which appear like a pair of supplemental coxæ. The basal segment of the abdomen. beneath is eonieally earinated.

Inhabits New Holland. In Mus. Brit. et Westw.

I have adopted the MS. name attached to this species in the British Museum eabinet.

THYNNUS TROCHANTERINUS, Westw.

(Plate 77, fig. 3.)

T. capite ct thorace nigro et pallide flaro-varits, abdomine pallide flavo, nigro cingulato, femoribus flavis basi et apice nigris tibiis tarsisque castaneis ot.

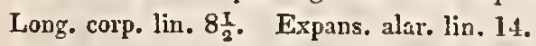

This species is nearly allied to Th. variegatus, Klug, but much larger, and with different coloured scutellum and feet. The 
head is of moderate size, black, and finely punctured; the hind margin with a slender yellow line, which extends behind the eyes, where it is dilated on each side; there is also a small yellow patch extending from the upper angle of each eye towards the ocelli; there is also a yellow patch between the antennæ at the base, these being rather wide apart. The clypeus is oval and yellow; the apex narrow and rather rounded; the space between its sides and the inner margins of the eyes is depressed and yellow, with a small black dot. The mandibles are yellow, with the tips black; the basal piece of the maxillæe and the mentum are black; the former' scarcely hairy. The terminal sixth joint of the palpi appears to have been broken off in both the palpi in my specimen; the terminal joint of the labial palpi is slenderer and longer than the preceding joint. The antenna are rather slender and filiform, being four lincs long; they are entirely black, whereas $T$. variegatus has the basal joint yellow. The pronotum is margined entirely with a rather narrow edge of yellow; the disc of the mesonotum is black, with four impressed lines and a yellow patch behind, and a slender lateral line; the wing-covers are also yellow; the scutellum is black, with a yellow lnnule across the middle, pointed in front; behind this is a slencler yellow curved line, united with two lateral yellow spots; and the metathorax has three yellow spots, the central one largest and dilated in front. The surface of the thorax is finely punctured, and slightly pilose; the prosternum. bears two yellow spots, and the sides of the mesosternum two fulvous ones beneath the insertion of the fore wings; this part is also clothed with fulvous pubescence. The abdomen is elongate, ovate, with the tip acute; it is pale-yellow coloured, the basal joint above with a small conical spot, two minute dots, and the hinder margin of black. The three following segments are marked with black transverse bars, the extremity of one and the base of the next being narrowly marked with this colonr; the middle of the inner edge of these bars is rather produced in front; the following segments are black; the fifth and sixth marked with yellow lateral lunules; the basal segment of the abdomen beneatl is conically elevated, and the other segments are coloured as above, the black margin of the second and third joints being very narrow; the anal segment is entire, but terminated by a minute slender actute point. The coxæ are yellow, with black marks; the trochanters black, the femora yellow, with the dise and apex black, the fore edgc of the antcrior and middle pairs being more chesnut, which 
is also the colour of the tibia and tarsi; the wings are slightly stained with yellowish brown.

Inhabits King George's Sound. In Mus. Westw.

THYNNUS TUBERCULIVENTRIS, Westw.

(Plate 76, fig. 2.)

Niger, griseo-pilosus clypeo flavo-vario, abdomine elongato nitido nigro, segmentis utrinque fulvo maculatis, scgmento 2ndo subtus tuberculis duobus parvis conicis instructo. कै long. corp. lin. 12. Expans, alar. lin. 20.

The head is small and black, closely and finely punctured; the clypeus is slightly prominent, and convex; yellow, with a slender curved dark line on each side, and a dark central spot; the apex is truncate, nearly concealing the ciliated labrum: the yellow margin of the clypeus is extended to the eyes, which have an abbreviated yellow margin to the lower part, both in front and behind; the head has also two minute yellow dots behind the eyes; the antennæe are black, with two minute yellow frontal dots; the mandibles are yellow, with the tips brown; the maxillæ and mentum are black, the former, as well as the maxilla, strongly fringed with pale hairs. In other respects, the trophi agree with T. Brownii. The thorax is entirely black, and clothed with gray pubescence; it is of an oval form; the abdomen is of an elongate oval form, broadest across the middle; it is black and shining, each segment with a large fulvous lateral spot, which becomes confluent on the sixth segment, the terminal joint being entirely fulvous; the basal segment is conically elevated in front above, and beneath it is not carinated; the second segment is, however, armed beneath with two small conical tubercles; this and the following segments are dark yellow, with black margins; the terminal segment is armed at the tip with a short acute black spine, the sides of which, at the base, are slightly dilated. The legs are chesnut-coloured, with the coxa and base of the femora black; and the wings are very slightly stained with yellowish brown.

Inhabits King George's Sound. In Mus. Westw.

THYNNUS (AGRIOMYIA?) MELLEUS, Westw.

(Plate 76, fig. 4.)

T. capite thoraceque nigris flavo variis, pronoto flavo, puncto parvo nigro, abdomine elongato fulvo, uigro-cingulato, pedibus fulvis, alis fla vis. $\hat{o}$ Long. corp. lin. $9 \frac{1}{2}$. Expans, nlar. lin. I6.

The head is rather small, black, and punctured; the eyes are margined with yellow, except on the crown of the head, the pale 
marginal line running across the back of the liead; between the antenure is a yellow $\mathrm{V}$ like mark. The clypeus is large, prominent, convex, and yellow, truncated at the tip, exposing the porrected semicircular and ciliated yellow labrum; the mandibles are slender and yellow, with the tips brown; the maxilla and mentum are pale ycllow-the former scarceiy ciliated; the maxillary palpi are rather short; the antennee are slender and filiform, measuring rather more than 4 lines in length. The collar is fulvous, with a snall black spot in the middle of the anterior margin. The mesonotum has the lateral margins rather elevated, and the middle marked with a yellow spot; the scutellum also bears a yellow spot of like size, followed by a curved yellow lunule; and the metathorax, which is broad with the lateral angles rounded, is marked with two oblique yellow lines; the wing-scales are yellow, and the space between the scutellum and postscutcllum is marked with yellow. The abdomen is oblong, rounded before and behind, and sub-depressed, of a rich orange colour, with the base and the incisions black; the anterior segment is channelled down the middle, and the terminal ventral segment is armed with a short acute deflexed spine, the sides of which, at the base, are dilated: the thorax beneath is black, clothed with silvery gray pile; and each side of the mesothorax and metathorax bears a yellow spot beneath the basc of the fore-wings. The abdomen beneatli is fulvous, fasciated with black; the legs are fulvous, with black coxæ; the posterior pair streakcd with yellow. The wings are golden yellow, with the stigma fulvous.

Inhabits King George's Sound. In Mus. Westw.

\section{THYNNUS (AGRIOHYIA?) TRIFIDUS, Westw.}

\section{(Plate 77 , fig. 4.)}

T. gracilis, elongatus nigcr, capite thoraceqne opacis flavo variis, abdomine nitido segmentis singulis 5 basalibus lunulis duabus flavis fasciolam nigram includentibus, pedibus obscure castaneis. ơ

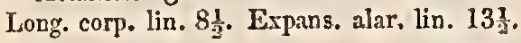

This species seems nearly allied to Agriomyia affinis, Guér. (Mag. de Zool., 1842, p. 4), but that species is too concisely described, and the original specimen too mutilated to allow me to determine its specific identity therewith. The head is obscure and black, and fincly punctured; the eyes margined witl yellow, except on the crown of the head; the middlc of the face witl a yellow $V$ like mark; and the front of the head narrow, yellow, and with a black, trifid divergent mark. The clypeus is rather 
emarginate at its anterior margin, exposing the labrum, whieh is yellow, and with its anterior edge slightly bilobed; the mandibles are yellow, with the tips black. The antenna are short and black (scarcely measuring 3 lines in length); the outer edge of the maxillæe is clotled with long white hairs. The collar is black, with an entire rather narrow yellow margin. The mesonotum is black with a yellow spot in tho middle, and a small one on eaeh side belind the wing-scales, whieh are also yellow; the scutellum bears a yellow conical spot; the apex directed towards the head : behind this is a narrow transverse yellow lunule, and two lateral yellow dashes; and the metatlorax bear's two oblique yellow lines, extending to the outer posterior angles; the sides of the thorax, beneath the insertion of the wings, are also spotted with yellow. Tho abdomen is elongate-ovato and depressed, broadest across the middle, black and shining; the five anterior segments bearing a large lunular yellow spot on each side, inelosing a short blaek transrcrse line whieh, in the fifth segment, unites with the black-ground colour of the segment; tho sixth segment bear's two minute and slender yellow lumules. The body beneath is clothed with gray puboscence; the eoxre black, with yellow stripes; and the abdomen black, each of the intermediate segments with two slender yellow lunules; the terminal segment is entire, and rounded at the tip; the legs are entirely chesnut red, and the wings stained with yellowish brown.

- Inhabits King George's Sound. In Mus. Westw.

THYNNUS (AGRIOIYIA \%) MARGINALIS, Westw.

(Plate 76, fig. 3.)

T. niger griseo subpubescens, clypeo oculisque (in parte inferiori) albido tenuissimo marginatis; abdominis segmentis quinque basalibus lunula tenuissima albida utrinque in margine postico notatis, pedibus duobus anticis castaneis, posticis uluobus nigris. $\hat{f}$

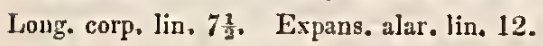

The head and thorax of this species are blaek, thickly but finely punctured, and not shining ; the latter elongate, with the scutellum rather elevated, convex, and less strongly punctured; the clypeus is rather short, eonvex, black, slightly carinated down tho middle and truneato at the tip, with a slender white margin extending as far as the eyes, to which it also forms a slender margin about as high as the insertion of the antennæ. The back part of the head is marked with two obseure red spots. The antennæ are blaek, the tips being, however, broken off in $\mathrm{my}$ 
unique specimen. The inandibles are black on the inside and yellow on the outside, the tips and inner margin being, however, black ; the maxillæ have a long row of slender hairs on the outside, and the palpi are rather elongated. The thorax is black, the wingscales and a very slender transverse line behind the scutellum being dirty white; the abdomen is black, depressed, narrower than the thorax, its broadest part being in the middlc; the five anterior segments marked on cach sile, at the posterior margin, with a very slender dirty white lunule; the basal segment has a deep longitudinal channel down the middle; the body beneath is black, with slight gray pubescence, the intermediate segments of the abdomen with extremely slender white lunules belind; the apical segment is entirc and rounded. The antcrior feet are castaneous, with the tips of the tarsi black; the middle feet are castaneous before, but black belind, and the hind feet are entirely black. The wings are slightly tinged with grayish, and the stigma is black. Inhabits King George's Sound. In Mus. Westw.

\section{THYNNUS DIMIDIATUS, Westw.}

(Plate 76. fig. 5.)

T. niger punctatus abdomine (segmento basali excepto) tibiis tarsisque ferrugineis, ano 5-dentato, $\hat{o}$

rong. corp. lin. 6. Expans. alar. lin. 93.

This curious species has the head and thorax entirely black, finely punctured, and clothed with slight gray pubescence; the clypeus is porrected between the niandibles, which are dark castaneous, witl tho tips black. The antenne are rather short (about two lines long), and black ; the trophi are black; the outside of the maxille clothed with long whitish hairs; the dise of the mesothorax is scarcely marked by the four impressed lines, and the metathorax is far more delicately punctured than the scutellum. The dorsal segment of the abdomen is black; the remainder darkbrick red. The segments are much constricted at the articulations, whcre in each is a transverse impressed line running across the joint, finely serrated; the penultimate segment is armed at each side with a short ferruginous spine, and the terminal segment with a deflexed acute black point, the base of which, on each side, is armed with a shorter black diverging curved spine; the legs are black, with the tips of the femora and the tibiæ and tarsi dark ferruginous. The wings are rather tinged with gray, and the stigma is black. 


\section{GENUS AELURUS, $\mathbb{K} L U G$.}

In my sketch of the generic arrangements proposed in this group of insects, given in pp. 102 and 103, I accidentally omitted to mention that Dr. Klug, in his Mcmoir in the Berlin Transactions for 1840, had described a new genus, founded upon two Brazilian species, which appeared to possess characters of higher value than those of the majority of the groups proposed by M. Guérin Meneville.

Dr. Klug chiefly relied upon the structure of the trophi of the male for the characters of his genus, not describing the parts of the mouth of the other sex, nor noticing a character which at once distinguishes the genus from all the other Thynnidcous insects which I have yet examined (except as mentioned below), namely, the homogeneous structure of the upper maxillary lobe, which, in the typical Thynnides, has the liorny portion divided into two parts by a narrow transverse leathery connexion; a peculiarity, doubtless, connected with the structure of the parts of the lowel lip, to which this lobe forms a defending sheath. That this division does not exist in Aelurus, I infer from Dr. Klug's figure $16 a$, compared with the same organ in the Australian insect, next to be described, which, notwithstanding some variation in the general form of the body, must, I conceive, be assigned to Dr. Klug's now genus, which is thus shown to inhabit the Australian as well as the South American Continent, a peculiarity in nowise surprising, when it is remembered that these are the two geographical seats of the whole group.

\section{AELURUS ABDONINALIS.}

(Plate $\mathbf{7 7}$, fig. 5 , and details.)

\section{Srw,-Agriomyia abdominalis, Guérin, Mag. de Zool, 1842, p. 5.}

A. niger aureo-setosus, collari punctis dnobus transversis, scutello macula flava notato, abdomino (basi scgmenti primi excepto) pedibusque fulvo-rufescentibus. $₫$

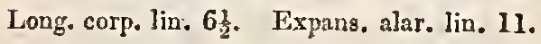

The head is black, transverse, and flat on the crown, and finely punctured, the face is furnished in the middle with two small tubercles, at the sides of which the antennæ are affixed; the clypcus is slightly porrected, with its extrenity truncate and yellow; the mandibles (fig. 5 , ) are fulvous, with the tips brown; they are clothed beneath with long hairs; the labrum is small, entire, and strongly ciliated. (Fig. 5 a.) The antennx are long, slender, black, and filiform, with the tips acute, (measuring nearly 
4 lines long); the maxillæ are small, with the apicai lobe rounded and homogeneous (fig. $5 c$, ) with the sides clothed with long hairs, and the palpi very long and slender, the basal joint being the shortest and the third the broadest. The mentum (fig. $5 d, 5 c$, ) is narrow (with the labium inflexed), the extremity fumished with a very long curved pencil of hairs (scarcely shorter than the maxillary palpi), and the labial palpi are clbowed at the tip of the first long joint, which is also furnished with a long diverging bush of hairs; the sides of the head are furnished with long fulvous hairs directed backwards. The collar is but slightly developed, with two minute transverse yellow spots in front; the mesothorax has its upper surface marked with four longitudinal channels; the scutellum bears a yellow spot, followed by a transverse yellow lunate spot; the metathorax is oval, attenuated behind, nearly polished, slightly sctose; the abdomen is rather long, depressed, and narrowed in front, the basal joint triangular, convex above, channelled down the middle; the base black, the extremity of the remainder of the abdomen of a fulvous castaneous colour, slightly clothed with fulvous hairs, the terminal segment is carinated beneath, tridentate at the tip, the middle tooth being the longest and black at the tip. The, coxre and trochanters arc black, and the legs fulvous castaneous. Wings almost hyaline, with black veins and stigma.

Inlabits Van Diemen's Land. In Mus. Westw.

I am indebted to R. H. Lewis, Esq., for this interesting insect.

M. Guérin has described another Australian species, allied to the preceding, under the name of Agriomyia spinolæ, with the observation that they differ from the rest of the genus, in their longer antennæ, and the long liairs at the sides of the head, so that they "pourraient bien devenir types d'un nouveau genre," for which he proposes the name of Tachynomyia, which, both on account of its want of priority in date and its insufficient characters must be rejected in favour of the name Aelurus.

The plant represented in plate 76 is Solanum stelligerum, and that in plate 77 is the Orchidaceous Aretlusa catenata.

Obs.-The curious structure of the antcrior coxa of T. interruptus laving induced me to examinc the same part in other species, I have found that the male of $T$. (Thynnoides) fumipennis, (ante, p. 108), possesses a singularity of structure which 
I have hitherto observed in no other insect, having the coxx dilated, and together forming a broad nearly circular cup, with the margins elevated, large enough to allow the under-side of the head to rest within it when deflexed.

Obs. 2.-Thynnus decipiens (ante, p. 105), is closely allied to T. dimidiatus above described; it may be thus characterized :-

T. decipiens; niger punctatissimus, abdomine elongato, segmentis constrictis, ultimis duobus ferrugineis, ano dentato dentibus duobus primis minoribus segmentoque penultimo etiam triden tato, pedibus nigis.

Long. corp. lin. 5. Expans. alar. lin. 91/2.

Habitat in Terra Van Diemenii, Mus. Westw. Communic. Dom. J. Hooker.

Obs. 3.-I have detected (June 14, 1844, a third Australian species of Aelurus in the collection of my friend G. H. K. Thwaites, Esq., of Bristol, of which the following are the characters:-

Aelurus morens; niger, eapite et thoracc obscuris cincreo paullo setosis, abdomine clongatoovato, segmento ultimo lateribus rotundatis apice in spinam parvam producto; capite setis longis griseis posticc marginato, naxillis et labio ut in congeneribus, alis fusco-tinetis.

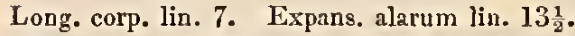

Habitat apud Melbourne (Nov. Holl.) Mus. Thwaites. 
c. 


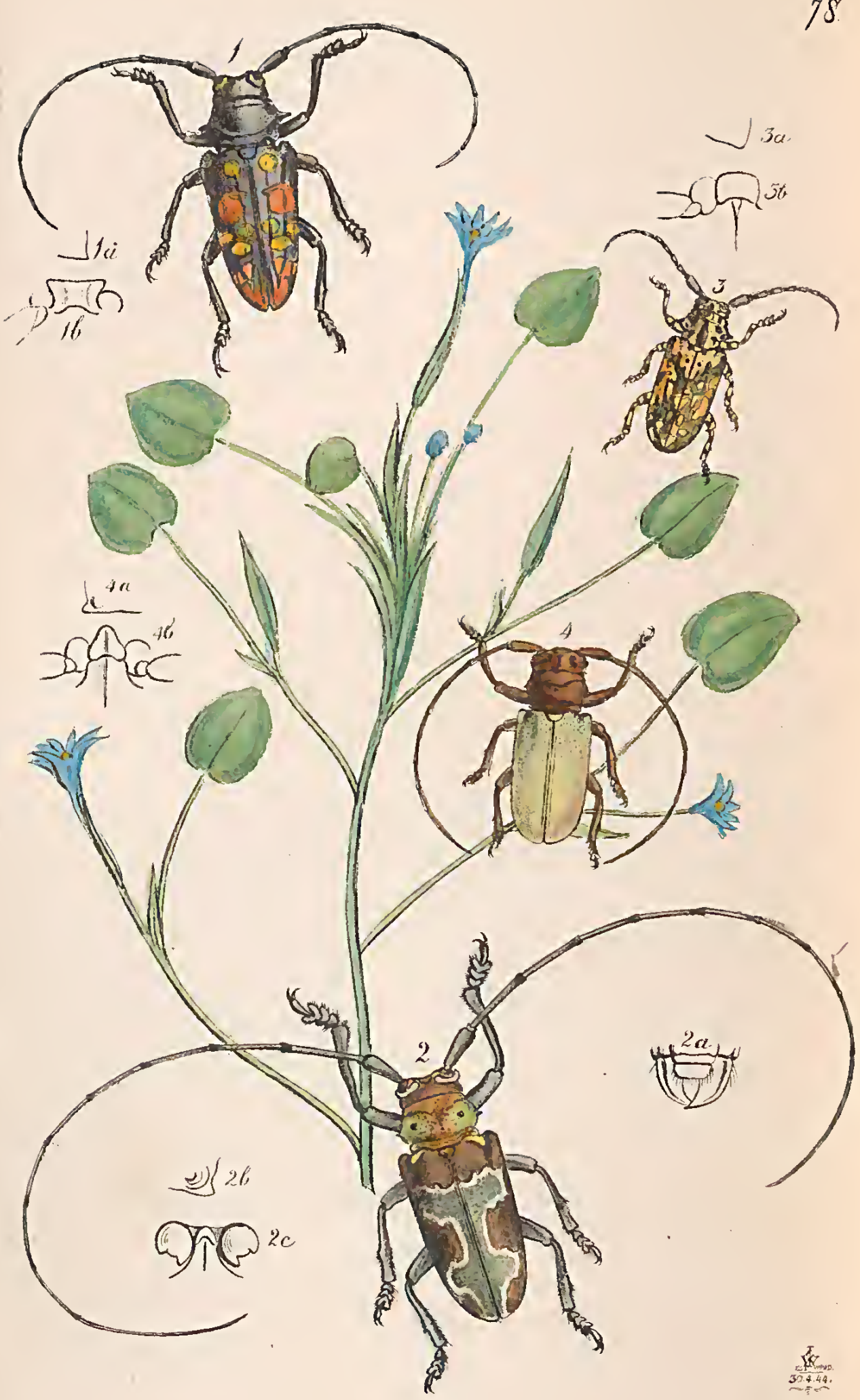


PLATE LXXVIII.

ILLUSTRATIONS OF SOME SPECIES OF LONGICORN BEETLES FROM TROPICAL WESTERN AFRICA.

LAMIA (STERNOTOMIS) CONES, Westw.

(Plate 78, fig. I.)

L. nigra nitida, elytris punetatis, maculis numerosis rotundatis, magnitudine diversis, albidis et fulvis, apieibusque fulvis nigro-striatis.

Long. corp. lin. 15. In Mus. Dupont, Parisiis.

Buack, pronotum strongly angulated in the middle of each side, from which runs a curved raised space; elytra much punctured; the humeral angles acute, and porrected; the disc of each with two longitudinal raised lines; near the suture are two round pale buff spots, edged with greenish, followed by two large round fulvous ones, rather before the middle, attached to the anterior edge of each is a slender pale line, and a small lateral dot; near the middle of each elytron are three smaller roundish spots of pale buff, arranged in a triangle, the outer one being the smallest; extremity fulvous, divided by the elevated black lines above mentioned: mesosternal process broadly truncate, but not very prominent (fig. $1 a, 1$ b.).

\section{LAMIA (STERNOTOMIS ?) PRINCEPS, Dupont's MSS.}

(Plate 78, fig. 2.)

L. luteo-fulra, clytris glaueo-albidis; basi, lateribus (versus apicem dilatatis), et fascia lata media (in medio interrupta), brunneis, antennis longis, sterno parvo eonieo.

Long. eorp. lin. I6.

Habitat in Guinea. In MLus. Dupont.

Head and thorax clothed with very short brownish luteo-fulvous pile, having a greenish tinge at the sides of the latter; the eyes margined with whitish. Antennæ long, 11-jointed; the terminal joint very long and slender; they are setose beneath for about onethird of their length, and are dark gray, with a brown tinge, the joints being black at the tips. Mandibles simple (fig. $2 a$ ); the sides of the prothorax are armed with a small spine; the elytra have a broad brown base, with the posterior elge irregular; the sides of the elytra are also brown, whicl colour extends into a large patch on each sidc, running more than half across the middle of the elytra; near the extremity, also, it is dilated into a broader patch of this colour; the remaining space is of a pale dull greenish colour, separated from the brown by a whitish line, following the irregularities of the latter; legs gray-brown; body beneath entirely 
brownisl lutcous-fulvous; mesosternal process small and conical (fig. $2 b, 2 c$ ), and but slightly prominent.

\section{LAMIA (STERNOTOMIS) EREMITA, Chevrolat's MSS.}

(Plate 78, fig. 3.)

L. Iutco-albida punctata, supra capitc et thorace nigro-maculatis, hoc striga media Iongitudinali nigra ante medium eonstrieta, elytris albido et nigro variis, plaga magna irregulariter triangulari pallida basali relicta.

Long. corp. lin. 10.

Habitat in Senegallia. In Mus, D, Cherrolat.

Upper side of the body pale luteous-buff, varied with black. The head has a patch in the middle of the hind margin, and two small spots on each side; the face has four minute oblique black spots; antennæ short, 11-jointed, black, each joint, after the second, having a broad gray ring at the base : the pronotum has a rather broad black stripe down the centre, and several irregular-shaped smaller black lateral spots, the sides being producer in the middle into an acute black point; the elytra have a largo pale irregular triangular-shaped patch at the base, with two minute black dots at the sides of the scutellum, and two at a little distance below it ; the remainder of the elytra are black and punctured, with numerous pale markings of irregular shape, and with pale irrorations upon the black parts; legs pale, with black rings; beneath buff-stone coloured, with a pinkish tingc; the middle of the body black and shining, a minute black spot on each side of the prosternum, and also near the outer hind angle of the mesosternum, and a spot on each side of the abdominal segments united with the black middle patch in the terminal segment. Mesosternal process broadly quadrate, and not porrected (fig. $3 a, 3 b$ ).

\section{LAMIA (STERNOTOMIS?) BICOLOR, Westw.}

(Plate 78, fig. 4.)

L. obscure fusca tomentosa, elytris pallide virescenti-sulphureis.

Long. corp. lin. $12 \frac{1}{2}$.

Habitat. Gold Coast, Guinea. In Mus. D. Carter.

Nearly allied to L. angulator Olivier, from which it differs in the form of the mesosternal process. Entirely covered with a dull brown silky pubescence, except the clytra, which are of a pale yellowish-green, with an opaline gloss. Eyes and mandibles black; antennæ 12-jointed; prothorax with the sides armed with a small pointed tubercle; mandibles simple, mesostemal process small, conical, channelled, and rather porrected (fig. $4 a, 4 b$ ).

The plant represented in the plate is Pontederia natans, Pal. d. B., a native of tropical Western Africa. 


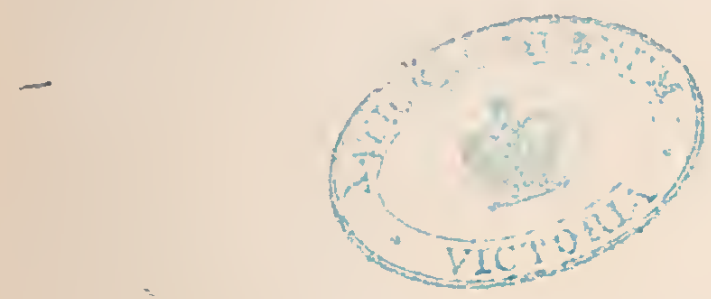




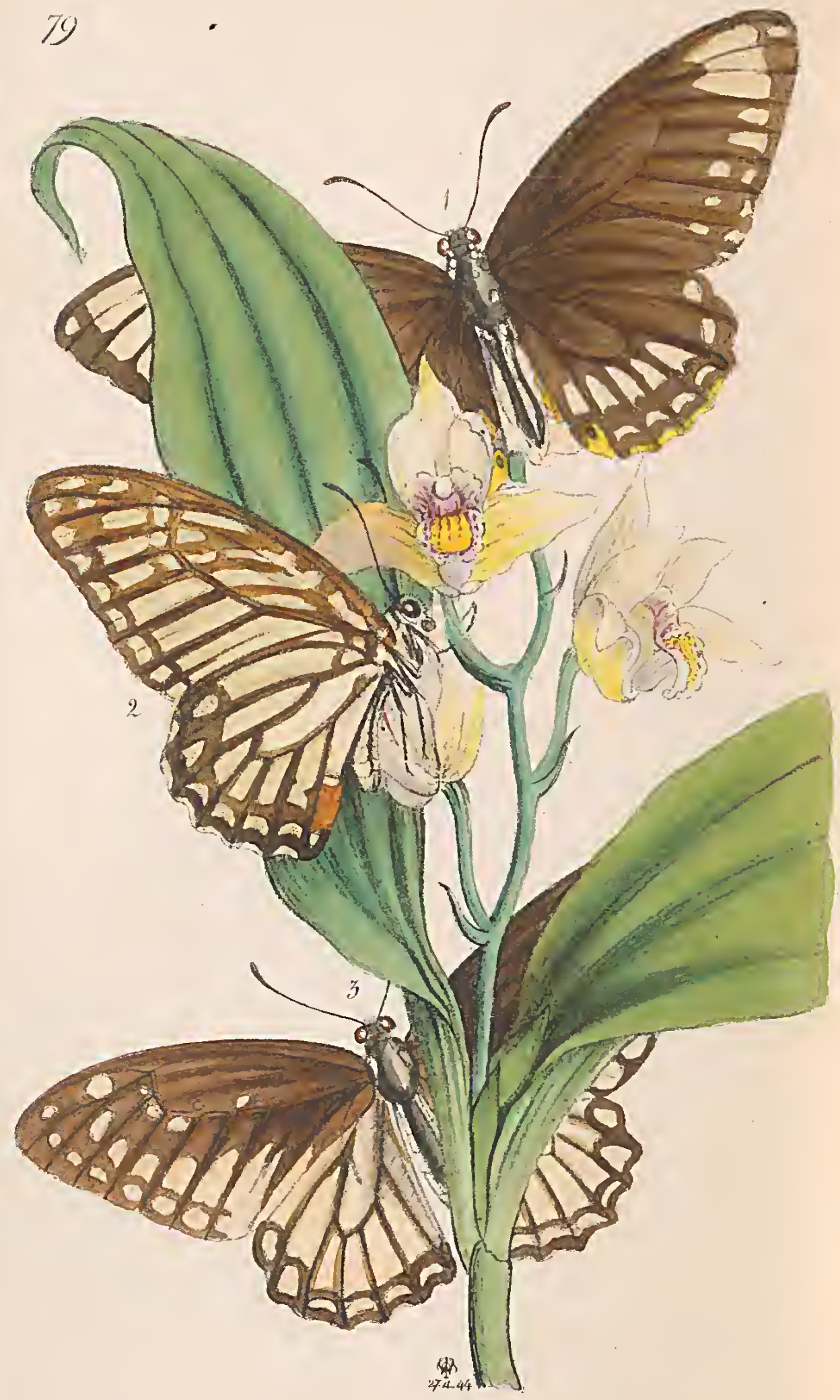


PLATE LXXIX.

DESCRIPTIONS OF THREE NEW ASIATIC SPECIES OF PAPILIO.

\section{PAPILIO PALEPHATES, Boisduval's MISS.}

(Plate 79, fig. 1.)

P. alis anticis oblongis snb-ovalibus, brunneo-nigris, seric duplici macnlarum albarum, versus apicem in plagam magnam dilatata, posticis ccaudatis maculis 5 cuneatis Innulisque sex submarginalibrs incisurisque fulvis.

Expans. alar. unc. $4 \frac{1}{6}$.

Habitat in Manilla. In Mus, reg. Paris.

Closely allied to P. Panope, Linn., of which it will probably prove only a geographical variety, differing from the typical Continental individuals in the large pale patch ncar the tip of the fore wings, and in the hind wings beneath having the veins margined with pale buff. In the disposition of the markings it otherwise accords with $P$. Panope, but its fore wings are more ovate, the apical margin being a little rounded; they are of a rich brown colour, with a large whitish patch, formed of three confluent oblong spots near the apex of the wing, followed by a single small oval spot close to the apex; and beneath these are several small conical spots, which become united with the marginal spots, of which there are only six, the apical portion of the wing not possessing them; besides these therc are three oval or round spots preceding them, towards the anal angle. The hind wings are brown, with five cuneated pale patches, extending from the anal margin, succeeded by six lunate pale spots extending from the outer angle, and with five fulvous incisural spots, the anal angle bearing a larger oval fulvous spot, in which is a black dot. The fore wings on the under-side are of a paler brown colour, but similarly marked beyond the middle; the base also with several pale dashes. The hind wings have the veins fron the base to beyond the middle edged with pale buff; half way between the discoidal cell and the hind margin of the wing is a row of five white crescents, shaded off into the ground colour of the wing, and separated by brown arclies from a row of white horse-shoe marks, within which are six large fulvous incisural marks ; the base of all the wings with small round white spots; the body and abdomen are also spotted with black.

\section{PAPILIO XENOCLES.}

(Plate 79, fig. 2.)

Sxx.-Papilio Xenocles, Doubleday, in Gray's Zool. Misc., p. 74.

P. alis sub-oralibus cerudatis, fuscis albido-virescenti striatis et maculatis, posticis macula fulva ad angulum ani notatis.

Expans. alar. unc. $3 \frac{1}{2}$.

Habitat in Assam. Iu Mus. H. Doubleday.

Nearly allied to P. Macarcus, from which it differs at once in the fulvous patch at the anal angle, in which respect it agrees with 
P. Laodocus, De H. (P. Delessertii, Guér.). The upper side differs from the under only in having the ground colour of all the wings dark brown. The species is described in the work above quoted.

\section{PAPILIO LEUCOTHOE, Westw.}

(Plate 79, fig. 3.)

P. alis sub-ovalibus, nigro-fuscis, anticis pone medium seriebus duabus macularum lactearum, internis majoribus, cuneatis (intermediis minoribus); alis posticis ecaudatis, lacteo-albidis renis margineque postico fuscis, hoc luuulis scx puuctoque anali albidis.

Expaus. alar. unc. 4.

Habitat in Iodia Orientali (circa Pulo Pcnang?*) In Mus. Britam.

Closely allied to P. Clytia $\dagger$ and Laodocus in the form of its wings and arrangement of the wing-veins (cspecially in the narrowness and length of the discoidal cell of the hind wings), but differs, especially from P. Laodocus, in its markings and colour, so that it cannot be supposed to be a suffused variety of that inscct. Fore wings above dark brown, with cream-white spots; in the discoidal cell are two minute white dots, just preceding the insertion of the second and third branches of the median vein; just beyond the extremity of the discoidal cell also marked with three small white spots, followed by a curved row of nine cuneated marks of unequal size, those towards the inner margin being the largest, the one nearest the costa is round; the seventh and eighth are confluent through more than half their length, and the ninth or innermost one is long and lanceolate; these are followed by a submarginal row of eight round spots, increasing in size to the inner margin, the last being confluent with the patches preceding it. Hind wings brown, with the veins edged with, and the outer margin brown, the latter with six pale submarginal spots; those towards the anal margin being lunate, the anal angle itself with a small pale dot. Under surface similar, but the brown colour is paler, and the base of all the wings is marked with several small round white spots. Head and thorax black, with white spots; abdomen black, with a broad white longitudinal stripe on each side; body beneath spotted with black.

The orchidaceous plant represented in the plate is the Trichosma suavis, Lindl., from the Khoseea district of India.

* This species was obtained in a collection recently sold by auction by Mess. Stevens, of King Street, Covent Garden, cootaioing specimeos of Pap. Laodocus, Fulgora Delessertii, and F. Lathburii K. \&c. ; Bo that it is most probable that it was from the southern part of the eastern peninsula of India.

+ It is accordiogly naoved after her favoured rival, Leucothoe. 



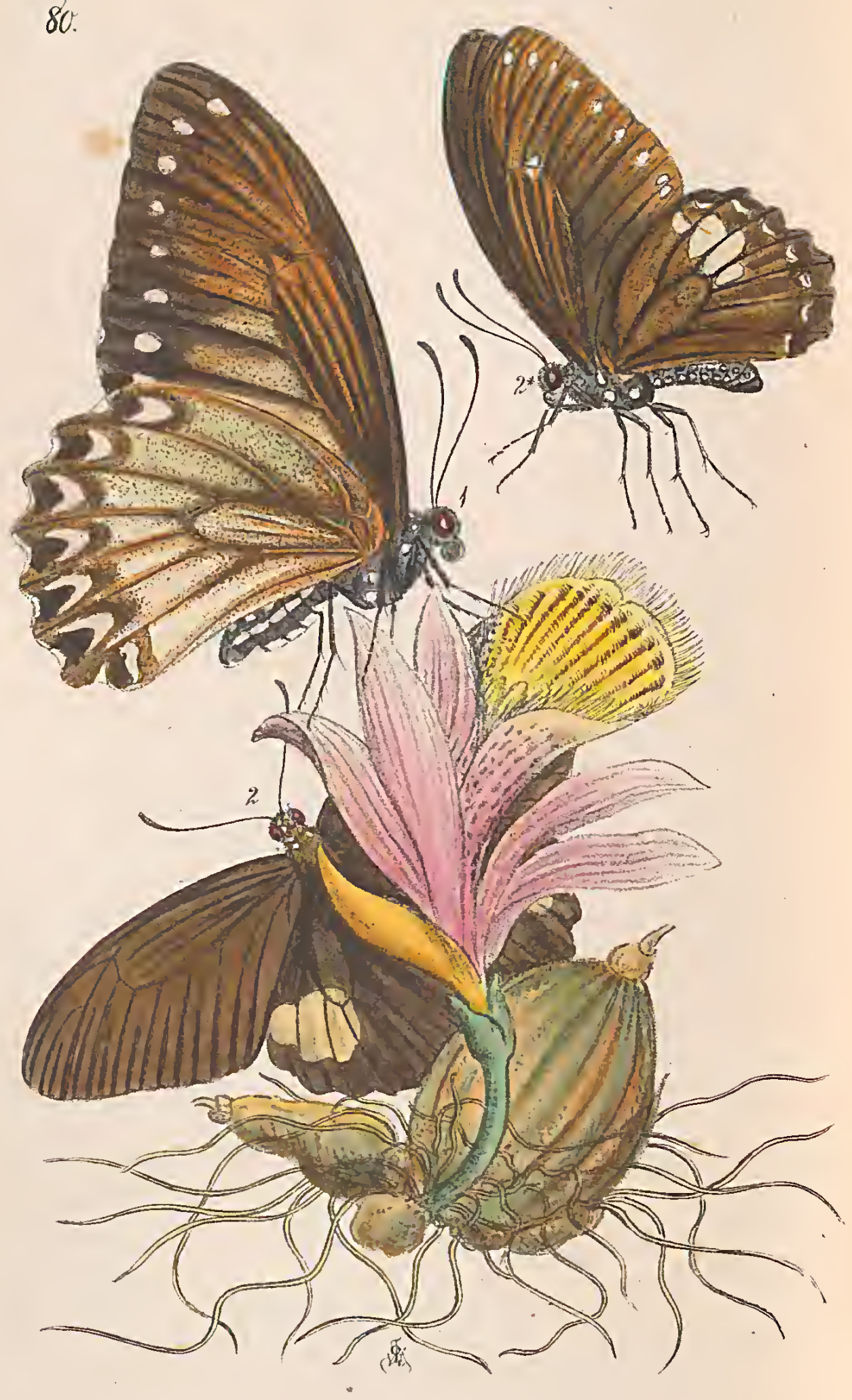


PLATE LXXX.

ILIUSTRATIONS OF TWO ADDITIONAL SPECIES OF PAPILIO, SENT
FROM ASSAM BY MAJOR JENKINS.

Srsce the publication of the 19th number of this work, in which two new spccies of Papilio, kindly communicated from Assam by Major F. Jenkins, werc figurcd, I have received two cases of insects from the same gentleman, in whicls were contained specimens of the two species represented, for the first timc, in the accompanying plate. They had previously, however, been described by myself in the Annals of Natural History, from specimens received from Sylhet by the Rev. J. Stainforth, now in the collection of H. Doubleday, Esq. In respect, therefore, to their geographical range, this circumstance beeomes of importance. It is also rather remarkable, that all these new Assamese species should be so little striking in their colours.

\section{PAPILIO POLLUX. Westw.}

(Platc 80, fig. I.)

P. alis latis posticis sinuatis ecaudatis, omnibus supra fuscis; anticis supra puncto ad apicem are⿰ discoidalis, serie submarginali et marginali punctorum ad apiccm extensis, albidis plagisque duabus plus minusvo obliteratis versus angulum internum; posticis fascia latissima albida seu virescenti (venis divisa) pone medium; serie lunularum submarginali sinubusque albo marginatis: alis subtus similiter coloratis at fulvo pulrerosis in partibus fuscis lunulisque submarginalibus posticarum majoribus, corporc albo puuctato.

Expans. alar. uuc. $4 \frac{13}{4}-5 \frac{1}{5}$. Variat magnitudine macularum coloreque fascix posticarum quæ subindc ferc obliterata est.

Habitat Sylhet et Assam. MIus. Doubleday ct nostr.

The under side of a fine light coloured specimen is here represented, the upper side differing in having the cream-white colour rather less diffused, especially towards the inner angle of the fore wings; somctimes, also, the marginal spots of the fore wings are entirely, and the submarginal ones nearly, obliterated towards the tip of the wings, except the large one next the tip; the large discoidal spots near the inner angle of the fore wings on the upper side are more or less obsoletc, and occasionally confluent with the adjacent submarginal patches.

\section{PAPILIO CASTOR. Westw. \\ (Plate 80, fig. 2 and 2*.)}

P. alis latis anticis apice subacutis, posticis sinuatis ecaudatis, omnibus supra fuscis, anticis renis strigisquo intermediis nigris, margine punctis minutis albis; posticis macula magna discoidali (versus angulum externum cxtensa) albâ in 4 vel 5 partes irregulares venis divisa; sinubus albo marginatis, anticis subtus macula parva ad apicem arese discoidalis,

NO. XXI.-1st SEPTEMIBER, 1844. 
serie submarginali punetorum (mpicalibus interdum obsoletis) punctisque marginalibus albis, posticis uaculis 4 albis discoidalibus versus angulum externum alterisque tribus milooibus ad marginem analem interdum adjectis, serie submarginali lunularum alharum sinubusque albo-narginatis; corpore nigro, albo-punctato.

Expans. alar. uuc. $3 \frac{3}{4}-4 \frac{3}{4}$.

Habitat Sylloct et Assam. Mus. Doubleday et nostr.

The plant represented in the plate is the Epidendrum humile, from Nepal. 



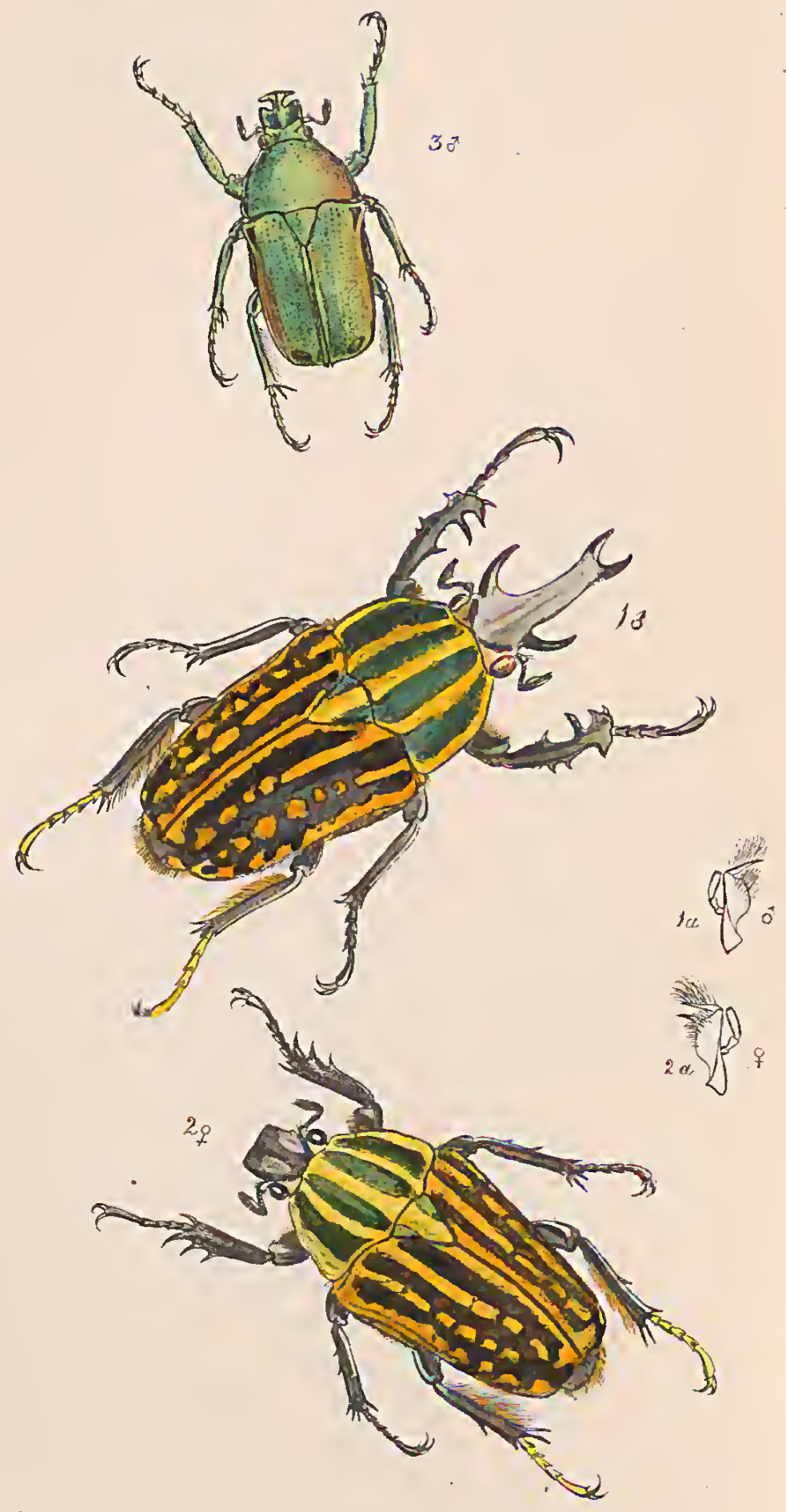

零 
PLATE LXXXI.

DESCRIPTIONS OF TWO SPECIES OF GOIATH BFETLES, FROM TROPICAL WESTERN AFRICA.

MECTNORIINA SAVAGII, Harris.

(Journal of Boston Soc. of Niat. ITist. vol. iv. pl. 21.)

M. pronoto obscurè viridi opaco lincis 5 flavis, elytris niggis velutinis sutura utrinque striisque tribus (in singulo) e maculis flavis plus minusve confluentibus notatis, tarsis posticis fulvis ô o.

Long. corp. of (cornu capitis incluso) unc. $2 \frac{1}{3} ;$ 우 unc. $1 \frac{3}{4}$.

Habitat Cape Palmas Africre occid, tropic. D. Sarage. In Mus. D. Hope.

(Plate 81, figs. 1, 2.)

The splendid addition to the family of the Goliath Beetles, represented in the annexed Plate, has been rccently discovered in tropical Western Africa, by Dr. Savage, and at his request I have added colourcd figures of both sexes of it to my former articles on this tribe of insects, although a previous description lias appeared from the pen of the talented Dr. T. WV. Harris, of Harvard University, Boston, U.S. It is closely allied to the two other specics of Mecynorhina, but differs from M. torquatus in its striped thorax, maculated elytra, and furcato horn of the clypeus, in all which respects it is nearer to M. Polyphemus, which is at once known from it by the dark gieen ground colour of the clytra, anterior tibire of the males multidentate on the inner edgc, and especially by the black colour of the posterior tarsi and the emarginate clypeus of the female of the Polyphenus.

The male has the hearl in front of the eyes armed with two porrected black hoins, bent outwardly, and the front of the head is produced into a horizontally porrected broad horn, furcate at the tips; the head and upper surface of the frontal horn are entirely clothed with a very fine grayish plush or slight velvety knap, the underside of the latter dark chesnut black; the two other horns are black. The disc of the head is considerably excavated. Tho thorax is dark opaque velvoty green above, with five broad yellowish stripes, the two intermediate ones rather dilated in the middle, and the lateral ones having only a very slender black margin. The scutellum is dark green, with a broad ycllow stripe along tho middle. The elytra are velvet black, each with 'thrce longitudinal rows of fulrous spots, and an irregular stripe of the same colour on cach side of the suture, the marginal and subsutural spots confluent from the basc to the middle. Each elytron 
is pointed at the extremity of the suture, being most conspicuous in the female. The podex is black, with two conspicuous square whitish spots. The fore legs are robust, the femora green, varied beneath with pale whitish plush; the tibir black, with threc unequal sized strong teeth on each side, exclusive of the apical spur, those on the outer edge being abruptly bent downwards; the tarsi of the four fore-fect black, middle tibire with the outer edge cntire, the apical spur bent, hind tibia simple on the outer edge, and with a thick coating of golden brown hairs along the inner: margin; posterior tibix pale fulvous, with the tips of the joints and claws black. The undcr side of the prothorax is thickly coated with whitish plush, as are also the sides of the meso- and metathorax ; the middle of the mesosternum and thighs are dark opaline green, highly polished.

The mesosternal process is broad, porrected and rounded in front, with a thick coating of fulvous pile on its upper side; the abdomen is dark chesnut, with the centre much depressed, and the podex is fringed with fulvous hairs.

The female agrees with the male in general characters, but has the head entire and unarmed, the clypeus broad, square, and entire, with the front margin reflexed; the disc of the head is marked with two oblong whitish patches of plush. The anterior tibix are entire along the inner margin, but armed with three extremely acute teeth on the outside; the middle tibix are armed with two teeth on the outside, near the middle, and the posterior ones with a single tooth in the middle; the underside of the abdomen is convcx and green, and the sides of the breast are covered with a yellowish gray plush, intermixed with coarse hairs.

Dr. Savage informcd Dr. Harris that this species and M. Polyphemus feed upon a vine that climbs upon very lofty trees, and that they wound the bark of the vine and extract the juice, the vine being full of a fluid as tasteless and limpid as water; and the natives when travclling in the wood, cut it off and drink the juices when no water can be casily obtained.

The males of these as well as of the other gigantic Goliath beetles are found by Dr. Savage to be much more numerous than the females. Every practical collector knows that this is the case with the common Melolonthæe and other species, which, like the Goliath beetles, are chiefly taken on the wing. With respect to the geographical distribution of these fine insects, Dr. Savagc observed 
that " the bliek shouldered $G$. cacieus abounds on the grain and ivory eoasts, and many specimens have been proeured at Cape Palmas. When in good eondition the black patch is always more or less eonspicuous on the shoulder of each elytron in this speeies, and is never replaced by the pearly white colour which appears on that part in Voet's figure and description; hence it still remains uncertain whether Voet's Cacicus ingens be a distinet species, or merely an aecideutal variety of the blaek shouldered species. The latter inhabits a tree that grows to the height of thirty or forty feet, with a diameter of six or eight inches, and can be taken in great numbers in the months of Deeember, January and February, when the tree renews its blossoms and leaves. The inseets are roasted and eaten by the natives, who say that they are very fat and sweet. Dr. Savage thinks that the Gold Coast, or rather the interior of Guinea, will be found to be the proper locality for Hegemon* Drurii. It is probable that Hegemon Goliatus may be obtained nearer the line, and partieularly baek of the Gaboon. Mecynorlina torquata is found at Cape Palmas, where many have been obtained within a few ycars. The tree upon which they live is supposed by Dr. Harris to be a speeies of Aeaeia. Dicronorhina micans has been taken at Cape Palmas also, but seems to be rare on that part of the coast.

It appears from the observations of Dr. Harris that "the food of the Goliath Beetles is fluid, like that of the Trichii and Cctonice, inseets belonging to the same natural family, but the latter live ehiefly on the neetar of flowers, and the former on the sap of plants. The long brushes on their jaws (maxillæ), and the diverging rows of hairs that line their lower lips, are admirably fitted for absorbing liquid food, while their horny teeth afford these beetles additional means of obtaining it from the leaves and juicy stems of plants, when the blossoms have disappeared. Thus every new discovery in natural history, even when least expeeted, serves to inereasc the evidenee of skilful eontrivanee and perfeet adaptation of strueture in all organized beings." +

* Dr. Harris proposes to restore the name Goliatus, as originally proposed by Linnaus to desiguate the species, and to replaee it, for the genus, by the name of Hegemon.

+ Harris in op. eit. supra. It would be interesting to learn whether any and what distiuction of natural habits exist between those Goliath Bectles which possess corneous dentated mandibles, and those wlich have them formed of a slender liorny blade. 
CERATORHINA (CEL.ORHINA) AURATA ô, Westw.

(Plate 81, fig. 3.)

In the former volume of this work (i. p. 180) I described an insect from the collection of J. Turner, Esq., of Manchester, under this name, being at the time acquainted only with the female. Recently I have observerl the male of this insect in the collection of A. Melly, Esq., and Dr. Savage has forwarded specimens of both sexes to the Rev. F. W. Hope from Cape Palmas. The male is accordingly now represented, in order to render the illustrations of the species complete. It measures (including the frontal horn) 14 lines in length, and agrees in colour and general character with the female. The front of the head is, however, prodnced and square, with the sides and middle rather elevated, and furnished with a rather short horn in the middle of the anterior margin, the extremity of which is greatly dilated and pointed at the sides. The disc of the head is hollowed out, its basal portion extending over the impression, and deeply emarginate, the lateral angles forming two points in advance of the eyes. The fore legs are rather long, with the tibix unarmed on the onter edge, but the inner edge is very finely serrated (although not perceptibly so unless seen under a lens); the niddle and hind tibia are also unarmed, and the abdomen is longitudinally channelled down the middle. The mando of the male is simple, and that of the female armed with a lorny spinc. 

8 倿.
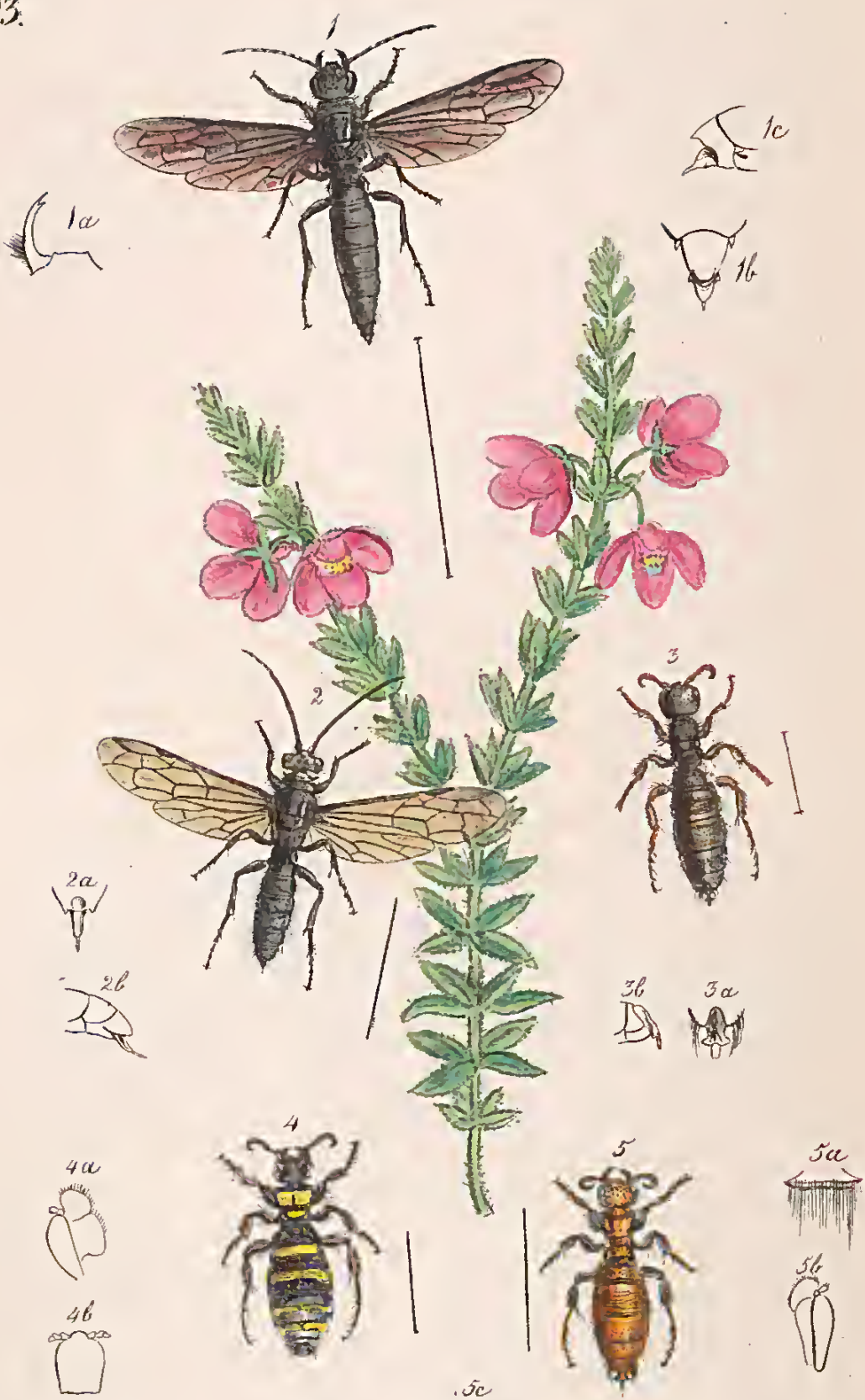

सै

(1)

(1)

10.

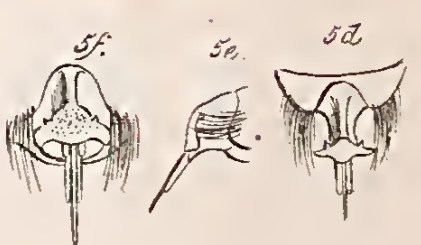



82

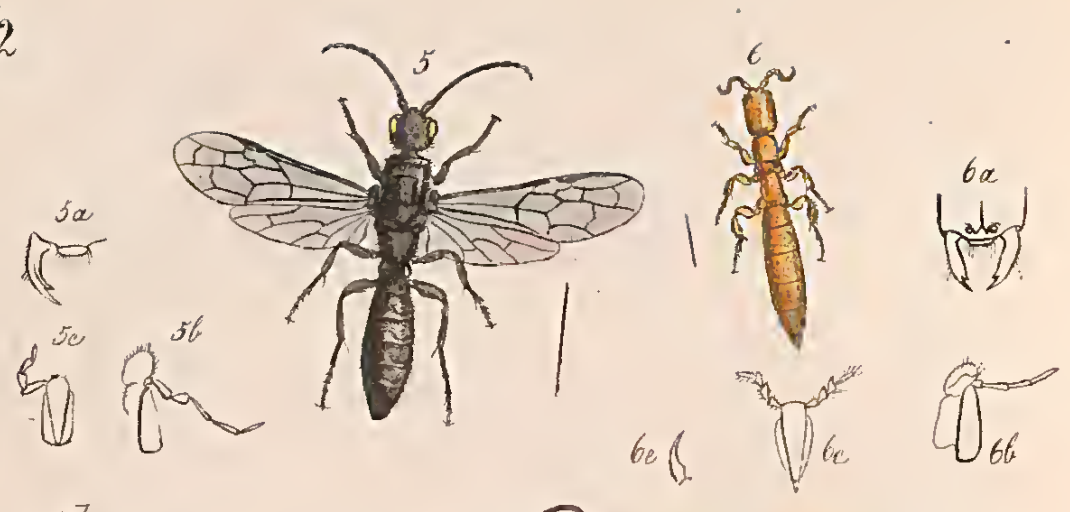

dis

(1)
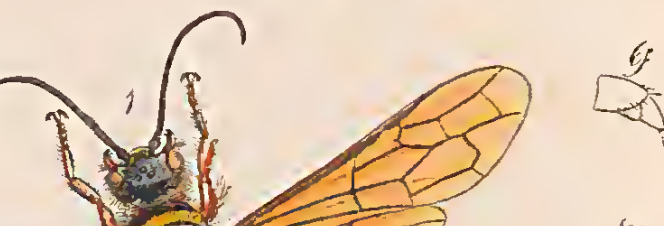

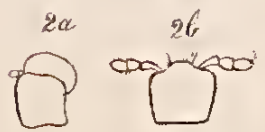
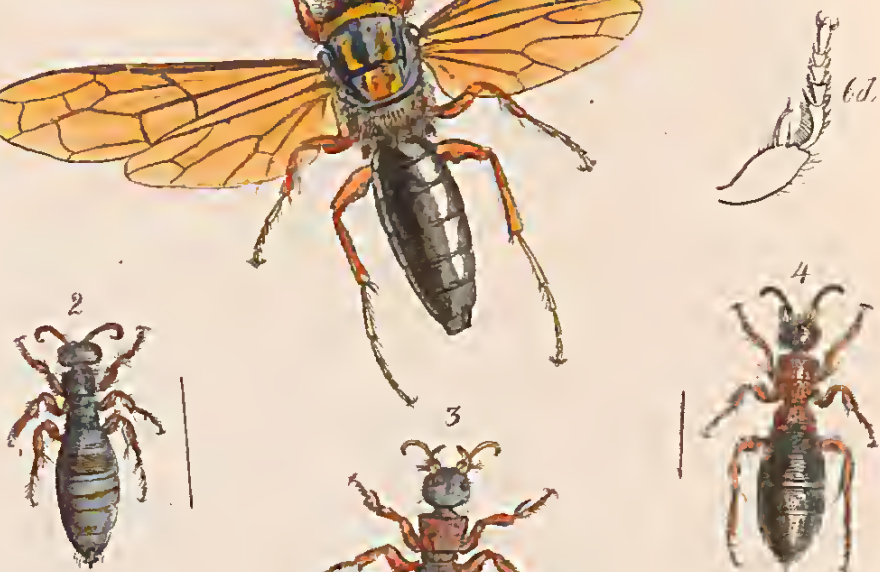

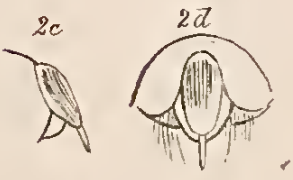

望空

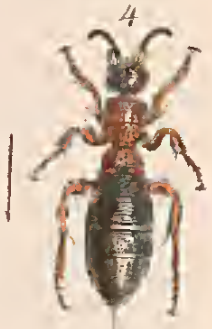

角

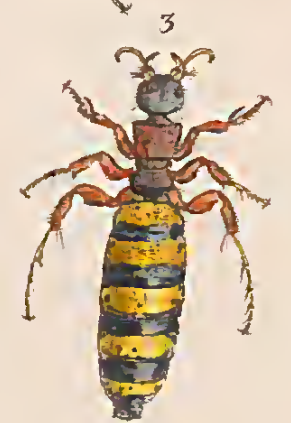

$\left\{\begin{array}{l}40 \\ +4\end{array}\right.$

$4 c$

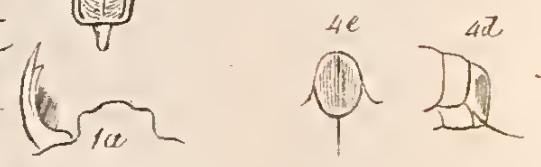

$$
\text { (ए) }
$$




\section{PLATES LXXXII AND LXXXIII.}

FURTHER ILLUSTRATIONS OF THE THYNNIDEOUS INSECTS OF

AUSTRALIA.

I'He Rev. F. W. Hope having, sinee his return from Italy, placed at my disposal his collection of Thynnidæ, containing several species, of which he had acquired both sexes from W. S. MacLeay and C. D. E. Fortnum, Esqrs., I am induced to add figures of these and some other allied insects to my previous illustrations, our knowledge of the true arrangement of this family depending so greatly upon the determination of the sexes of the different species.

\section{THYNNUS LEACHIELLUS, Westw.}

\section{Plate 7 , fig. 1 o. (T. interruptus.) Plate 83, fig. 4 우.}

Both sexes of this spccies having been received by Mr. Hope from Mr. MacLeay, the female is now represented. In several respects it differs from the females of the more typical species; but as these differences appear to be of no higher than specific value, it is unnecessary at present to establish a separate subgenus for its reception. The female is black varied with yellow, the head black and shining, of nearly equal brealth with the prothorax; it las on each side a deep longitudinal impression, extending from the base of the antennæ to the back part of the head, leaving the middle of the face much elevated. These impressions are smooth, but the rest of the head is punctured. The antennæ are black, the mandibles pitchy and entire, with the tips black. The lower parts of the mouth are minute, the palpi of the maxillize almost obsolete and apparently two-jointed (fig. $4 a$ ), and those of the labium rather larger and threc-jointed (fig. $4 \mathrm{~b}$ ). The prothorax is smooth, polished, and nearly flat on its upper side, being almost entirely, cxcept along its posterior margin, occupied by a broad yellow fascia, bearing a short brown line in the middle; the mesothorax is short, narrow, and yellow, and the metathorax black, nearly as broad as the prothorax, angulated at the sides, and with the posterior extremity transwersely deflexed. The legs are black, with the articulations pitchy and the tarsi paler. The fore tarsi are densely spinose, the niddle tibire thick and also setose, the sctæ mixed with short spines, and the hind tarsi long, slender, and very setose. The 
abdomen is large and eonvex, the basal segment with a yellow faseia before the extremity, and behind the fascia marked with two slender elevated earinated strix. The seeond segment is large, with a yellow fiseia, and with the entire surfaee marked with fourteen or fifteen transverse elevated earinated stria. The third and fourtl segments aro blaek and polished, the third with a slender pale yellow faseia, dilated into a round yellow spot at eaeh side, and the fourth with a rather broader faseia, interrupted in the middle, and also dilated at the sides; the fifth segment is very deeply emarginate above for the reception of the sixth segment, which is very delicately transversely streaked at the base and sides, the extremity forming a thiek truneated anal appendage (fig. $4 c$, $4 d$ ), rounded beneath, where it is marked by a semieircular impression. The abdomen beneath is entire, with the fifth segment longitudinally striated. The length of the female is nearly six lines. The speeimen of the male sent by Mr. MaeLeay with this female is smaller than my individual, measuring only $10 \frac{1}{2}$ lines in length, and having the head and thorax more coated with fine short hairs, my speeimen having been injured by the attaeks of inseets.

Mr. Maeleay has forwarded this speeies under the name of $T$. interruptus, Leach, being the same name as is applied to the male in the British Museum eolleetion, and whieh was thenee adopted by me in p. 115. As, however, Dr. Klug has deseribed a species from Southern Brazil with the same name, I have been compelled to give it a new speeific denomination.

THYNNUS SHUCKARDI, Guérin.

(Matér. s. 1. Thynnides, Mag. de Zool. 1842, pl. 100, fig. 13 đ. T. ferrugineus, Leach MSS.)

'The male of this inseet having been described and figured by $M$. Guérin Méneville, in the Magasin de Zoologie for 1842, I have not thouglit it necessary to refigure it; but as Mr. Hope has reeeived both sexes from Mr. MacLeay, I have figured the female, and added M. Guérin's deseription of the male, which is as follows:-

Male.- "Noir chaperon et" base des mandibules jaunes, tête et abdomen [thorax*] eouverts d'un duvet jaune très-dense et à reflets dorés soyeux. Dessus de l'abdomen d'un jaune ferrugineux, plus pâle à la base avee la plaque inférieure du dernier segment trèssaillante en arrière laneéolée, striée transversalement et terminée

* I presume that M. Guérin has made a mistake, by describing the abdomen instcad of the thorax as covercd with down, the abdomen being uaked in the section of the genus to which T. Shuckardi belonge. 
par une épine aigue ot un peu arquée en haut. Ailes jaunes transparentes à base, ot nervures brunes. Antennes, pattes et dessous du eorps noirs, avec un faible duvet gris-jaunatre. Long. 26 mill. [13 lin.] Hab. la Nouvelle Hollande." *

Female.-(Pl. 83, fig. 5.) The speeimen of this sox sent by $\mathrm{Mr}$. MaeLeay in eompany with the male, is seven lines long, and of a ehesnut colour. The head is eonvex and punetured, slightly broader than the prothorax; the antenna ehesnut-brown, the clypeus truncate in front, the labrum short aud strongly eiliated (fig. 5 a), the mandibles aro large, siekle-shaped, and ontire, eliesnut eoloured, with the tips blaek and furnished with long hairs on the outer margin of the under side; the maxilla (fig. 5 b) are small and the maxillary palpi almost rudimental, the mentum also small and furnished with minute 3-jointed palpi (fig. 5 c). The prothorax is almost flat above, and nearly transversely quadrate, with a row of strong punetures along its fore margin; the meso and metathorax are more punetured, the latter with the sides obtusely angulated, and its hind part not so suddenly and transversely deflexed as in the preeeding speeies; the femorn are blaek, the tibir (espeeially the foro pair) more pitehy, and the tarsi pitehy and very setose; in their strueture they agree with the preeeding speeies. The abdomen is large, oval, and eonvex, the basal segment rugose, with a earinated transverse stria near the apieal margin; the following segment is large, with seven or eight earinatod transverse stria across it, the posterior ones being wider apart; the third segment is irregularly punetured, as is also the 4 th on its posterior margin, where it is furnished with irregular gray hairs; the fifth segment is deeply emarginato for the reeption of the anal segment, whieh is contrated at its base and dilated into a flattened truneated terminal plate, with a minnte tooth on eaeh side above and a waved slit below, whenee the exserted aeuleus and its appendages aro emitted; the sides of the preeding segment are furnished with long golden-eoloured seta; the entire body is blaek beneath, the abdomen entire, and punetate, and the fifth segment irregularly but transversely rugose.

* The following are the characters of a species in my collection closely allied to $T$. Shuckardi :-

Tuynnus Guerixi, Westw. Niger, capito et pro- et mesothorace aurotomentosis, mctathorace griseo piloso, clypeo et mandibulis flavis; abdomine lrevi nitido supra fulvobrunneo basi pallidiori, subtus nigro, brunnco vario, spina apieali lanccolata, basi utrinque angulata apiceque acuto instructo, alis laridis anticis basi fuseis venis stigmateque nigricantibus, femoribus niglis tibiis tarsisque pieco.brunneis. Long. Corp. lin. 12. Expans. alar. lin. 23. Habitat King George's Sound. Mus. W'estr. 
THYNNUS (TIYYNNOIDES) OBSCURUS, Klug.

(Ueber Thynnus F. p. 22, Pl. annex. fig. 4 f.)

The male of this species having been described and figured by Dr. Klug, the opposite sex only is here represented; both sexes having been forwarded to Mr. Hope by Mr. MacLeay, under the name of T. nasutus Mc. L.

The male is described as follows by Dr. Klug:-

Th. fusco-niger albido villosus, pedibus brunneis. Mas. Long. lin. 10.

Ubique dense punctatus. Clypeus porrectus dorso convexus, carinatus apice truncatus, flavo marginatus. Mandibula flave marginibus apiceque nigris. Antenna abdominc vix breviores. Prothorax apice membranacc us pallidus, tegula apice testaces. Caput antice, gens, pectus, metathorax, latera abdominis denso albo villosn. Alx infuscata, ncrris stigmateque nigris. Pedes brunnei, coxis, tarsis, anticorum femoribus basi nigris; abdominis segmentum dorsale ultimum dorso impressum; spina in abdominis apico porrecta lanceolata acuta iocurva, basi utrinque obsoleto tuberculata.

This sex, which I have received from Mr. Curtis, differs from the males of the other Thynnoides in not having the anterior coxæ dilated and cup-shaped.

The female (Plate 82, fig. 2,) partakes of the obscure and sericeous appearance of the male, being black, with a slight pitchy tinge, the head convex and extremely delicately punctured, the punctation being visible only with a lens, the clypeus short and truncate at the tip, the mandibles reddish, with the tips black, the antennæ pitchy, the maxillary palpi (fig. $2 a$ ) almost obsolete, the labial palpi (fig. $2 b$ ) longer and 3-jointed. The thorax is black and finely punctured, the hind margin of the prothorax mombranous and pitchy, the legs pitchy brown and thickly sctose; the abdomen is large and convex, the first segment widely punctured, with a single carinated stria near the hinder margin, the second segment large and transversely marked with about seven carinated strix, the third segment is very finely punctured, and divided transversely into tro parts by an impressed line; the hind part of this and the following segments clothed with very fine gray down. The anal segment (fig. $2 c, 2 d$ ) is deflexed, oval-truncate, and longitudinally striated, with the aculeus exserted and directed downwards; the basal segment beneatl is angulated. The body beneath is black, with a gray scriceous coating, and with the fifth segment very thickly punctate. The specimen of the female sent by Mr. Macleay is six lines long. 
THYNNUS (THYNNOIDES) GRACILIS, Westw.

(Plate 83, fig. 2, 3.)

f* Th. elongatus, totus niger, alto-setosus, alis hynlinis apicibus obscurioribus, coxis anticis subcochleatis.

Long. corp. lin. 8. Expans, alar. lin. 14.

\& piceo-nigra, grisco-setosa, abdomine nigricanti, segmentis posticis posticc pụnctatis.

Long. corp. lin. 5.

Ifabitat prope Portum Lilclaidx. D. Fortnum. MIus. D. Hope.

The male of this speeies (fig. 2) is of a more attenuated form than in tho othor Thynnoides. It is uniformly of a black colour, and clothed with silvory whito hairs on the under-side of tho body and legs. The head is transverse, black, and punctured with a tubercle between the cyes, at the sides of which tho antennae are placed, a slender, straight, polisherl lino running down it and the elypeus, which is considerably produced, eonvex, punctured, with the extreme latcral edges whitish; the mandibles and palpi aro black, the antenna rather slender, and about the lengtl of the abdomen; the thorax is black and punctured, tho anterior lateral angles of the prothoracic eollar are angularly prominent. The mesothorax is markerl on each side with two impressed lines near the tegule, and within these aro two abbreviated inipressions, not extending to tho anterior margin; the tegulae are black. The abdomen is black, with the segments slightly constricted, each with a strong transverse impression across tho base, and with a semicircular prominence on each sido beyond the middlo. The seventh segment is furnished with a small, cirenlar, and rather deep impression near its extremity abovo, and with a minute tubcrele on each side (fig. $2 a, 2 b$ ), and the extremity of tho abchmen is armed with a slender spine, the tip of whieh is suddenly attenuated. The legs are slender, black, and clotlied with grayisl white hairs; the antcrior coxa are dilated and slightly excavated. The abdomen bencatll is strongly punetured; the anterior and second segment not angulated nor tubcrculated in tho middle, but the second and three following segments lave on each side, towards the posterior margin, a very slight eonical protuberance, with a slightly elovated lino extending between them. Tho wings are hyaline, with the tips dusky, more especially at the extremity of the marginal cell.

The female (pl. 83, fig. 3) is also rather more slender than those of the preceding species; it is of a pitchy black colour, the abrlomen being blacker than the rest of the body. 'The head is broader 
than the prothorax, and nearly rounded, convex, remotely punctated, and sparingly furnished with gray hairs; the mandibles pitchy, with the tips black; the antennæ obscure pitchy. The prothorax is smooth and polished, with a row of setigerous punctures in front. The meso and metathorax are punctured, the latter with the hind part obliquely truncate. The abdomen is elongate cylindric, with the ends rounded, the basal segment deeply but remotely punctured with a transverse carinated stria, at a little distance preceding the hind margin, the space between these being delicately rugose; the second segment has one of these carinated strix at a little distance from the base, and another at the like distance from the hind margin, the intervening space occupied by five curved stria ; the third segment has also one of these strixe near its base, the space between it and the hinder margin thickly punctate; the basal half of the two next segments is smooth, and the hind lialf punctured; the fifth segment is thickly setose, and the sixth forms a porrected deflexel anal appendage, dilated in the middle (fig. $3 a, 3 b$ ). The legs are pitchy and setose; the middle and hind tibire also armed with minute spines on the outer edge. The body beneath is pitchy; the abdomen entire beneath, with the first and second and the posterior lialf of the following segments thickly punctured.

THYNNUS KRUGII, Hope MS.

(Plate 82, fig. 1.)

T. niger subtus argenteo-sericeus, clspeo et eollare fulvis, scutello elevato pedibusque brunneis, metathorace et abdominis basi griseo lanato; alis fulvis venis brunneis $\hat{o}$.

Long. corp. lin. 18. Expans, alar. lin. 32.

Habitat Swan River. D. Roe. Mus. Hope et Brit.

This fine species, by far the largest in the family, has been appropriately named by the Rev. F. W. Hope, in honour of Dr. Klug.

The head is black and delicately punctured, rather depressed on each side, between the ocelli and eyes, the front of the head furnished with a broad tubercle, at the sides of which the antennx are affixed; these have the basal-joint pitchy and the remainder black, and with the apical joints attenuated to a point; the clypens is prominent and convex, nearly truncate at its extremity, and concealing the labrum, and is fulvous; the sides of the facc above the mandibles (fig. 1 a) are thickly coated with fine silvery liairs, the mandibles are robust and fulvous brown, with the tips and 
imner margin black; they are furnished near the base beneath with a strong brush of fulvous hairs, the inferior parts of the mouth and the palpi are fulvous, the head beneath is black and thickly setose. The prothorax is dark fulvous, with the anterior margin prominent on each side, the tegulæ are fulvous, the mesonotum is black, with the lateral margins rather elevated and two impressed longitudinal lines coated with short fulvous down; the scutellum is brunneous and elevated in the middle into two slightly conical tubcrcles, the metanotum is black, minutely punctured and densely clothed with fine gray hairs. The abdomen is nearly as long as, but narrower than, the head and thorax, it is elongate-ovate, convex above, black, shining, and scarcely punctatc, the basal joint rather abruptly deflexed to the place of its insertion, and with a brush of gray hairs on each side; the seventh segment is abruptly deflexed, striated and truncated, the last ventral segment terminated in an obtuse deflexed and curved point (fig. $1 b, 1 c$ ). The femora and tibia are dark chesnut, the posterior pair of the former angulated in the middle of the hind margin and terminated below in a spine; the tarsi are paler, the posterior pair being twicc as long as the tibiæ, the basal joint of the anterior tarsi is coated with short silver gray hair on its outer edge. The wings are large and stained deep yellow, with brown veins and stigmata; the supplemental vein in the first submarginal cell is very slender; the body bcncath is black, finely punctured and thickly pubescent; the anterior coxæ and the bifid point of the mesosternum brunneous; the latter is marked witl three longitudinal impressed lines, which do not reach the antcrior margin.

\section{THYNNUS GRAVIDUS, Westw.}

(Plate 82, fig. 3.)

Th. niger, antennis mandibulis prothorace ecutello pedibusque rufo-castaneis, abdomine maximo flavo fisciato. Long. Corp. lin. 14.

Ilabitat in Nova Hollandia. Mus. Hope.

The large size of this insect, together with its peculiar colouring and the structure of its hind femora, induce me to think it probable that it may be the female of Th. Klugii.

The head is small, black, and convex above, the sides and hind margin being nearly straight, with the angles rounded off: it is thickly punctated, especially in front where it is produced into a bifid tubercle, at the sides of which the antennæ are inserted; these, judging from the two basal joints, are fulvous brown, as is also the 
very short clypeus, and the broad but entire mandibles, of which the tips are black, and the under-side furmished with long hairs (fig. $3 a$ ); the labrum is short, exposed and setose; the maxillary palpi are very small, but they consist of six joints (fig. $3 \mathrm{~b}, 3 \mathrm{c}$ ); the labial palpi are also minute, but they are four-jointed (fig. $3 d$, $3 e$ ); the prothorax is large and quadrate, being broader than the head, with the posterior portion rather narrowed; it is finely punctured and has a circular inpression on each side, which may, however, possibly be accidental; the mesothorax is small and chesnut-red, and the metathorax black and punctated, with the lateral angles rounded off. The abdomen is very large, and semicylindrical, the first and second segments being destitute of gloss and very finely rugose, and the remaining segments glossy and impunctate; the anterior segment is yellow above, with several black dots on the deflexed basal part, and the hind margin is also black; the second segment has the anterior and posterior margin black, and of equal breadth; the following joints are also similarly coloured, but the black basal part is much broader than the posterior margin; the sides of the intermediate segnicnts are also dotted witl black; the fifth segment is nearly as large as the preceding and not emarginate at its hinder edge; the terminal segment is entirely black, thick, convex above, truncated at the extremity, with the sides slightly striated $(3 f, 3 g)$. The abdonen beneatl is pitchy, varied with obscure red, the fourth segment laving two transverse marks of this colour; the first segment is angulated at its base. The legs are chesnut-red; the anterior sliort, with the spur at the extremity of the tibix half as long as the tarsi ; the basal joint of the tarsi, on the outer edge, spinose; the posterior femora are cmarginate on the hinder edge, beyond the middle, and the posterior tarsi are twice as long as the tibiæ.

The six-jointed maxillary and four-jointed labial palpi, together with the strong spur of the fore-feet, the character of the second segment of the abdomen, and the notched posterior fenora, are characters which do not occur in the females of the typical Thynni. I cannot, however, regard them as of higher value than specific, considering that the true character of the females of the genus Thynnus consists in the rudimental size of the palpi, and which is not overbalanced by their possessing the typical number of joints. 
THYNNUS PURPURIPENNIS, Westw.

(Plate 83, fig. I.)

Th. niger nitidus griseo parum setosus, abdomine elongato subdepresso, alis nigrieantibus purpureo-nitidis.

Long. corp. lin. 12. Expans, alar, lin. 20.

Habitat in Nova Holland. Mus. D. Turner.

This very distinct species is entirely of a black colour, more or less clothed with fine silvery pubescence, especially on the under side of the body and face. It is of a long and narrow form, almost approaching that of the males of Rhagigaster. The head is strongly punctured with a wide but slight tubcrcle in front, at the sides of which the antenna are placcd; the clypcus is long and truncate, concealing the labrum; and the mandibles are curved, rather slender, and with a tooth within near the tip, clothed on the under-side with long slender hairs; the antennæe are slender, pointed at the tips, and scarcely longer than the thorax; the maxillary palpi are six- and the labial four-jointed. The thorax is finely punctate; the scutellum convex and slightly elevated, and the metathorax clongated. The abdomen is long and sub-dcpressed, each segment (except the first and last) with a rather deep transverse impression across the base, and with the lateral portion of each towards the lind margin more convex, so as to render each segment more convex just preceding the posterior margin. The sixth segment is armed with a small tooth on each side at the extremity, and the anal segment is terminated by an obconical, flattened horn, finely pointed at its tip (fig. $1 b, 1 c$ ); the wings are black, with a fine purple gloss, and the tips rather lighter coloured. The legs are black; the intermediate segments of the abdomcn bencath are marked with a transverse slender impressed line ncar the base.

\section{ENTELES, Westu.}

Subgenus novun characteribus fomineis adhuc tantum distinguendum, Thynnis typicalibus valde affine sed palpis perfectis gaudens.

Capat mediocre suliquadratnm convexum; mandibulx integræe curvatæ imberbes. Labrum clypeo laud abseonditum (fig. 4 a). Misxillne (fig. 4 b) perfecto palpis forma ordinaria 6-articulatis. Mentum elongatum (fig. $4 c$ ) basi attenuatum supra longitudinaliter carinatum, Iabio omnino retracto, pal pis labialibus perfeetis 4-artieulatis. T'horax tripartitus apterus. Aludomen magnum couvexum, segmento sceundo supris striolato apicali obtusè truncato (figs. $4 d, 4 e$ ). Pedes robusti setosi fossorii ungruibus apice bifidis. 


\section{SPECIES Unica, ENTELES BICOLOR, Westw.}

(Plate 82, fig. 1.)

Th. (Ent.) niger, mandibulis thoraco et pedibus rufis ․ Long. corp. fere lin. 4. Iabitat King George's Sound. Mus. Westwood.

The head is black and punctured; the mandibles red, and not bearded beneath: they are entire along the inner margin. The antenna are short and black; the thorax is strongly punctured above, as is also the abdomen, which is entirely black, except the terminal deflexed segment, which is pitchy-red at its extremity. All the segments have a carinated stria across, near the hinder margin, and the second segment is also marked with five or six similar stria across its disc. The apical segment is obtusely truncate, deflexed, and longitudinally striated, emitting the aculeus from its lower extremity. The legs are red, robust, and apparently formed for burrowing.

\section{EIRONE, Westw.}

Mas, alatus. Labrum ciliatum clypeo hand absconditum. Mandibulæ intus dente subapicali instructæ (pl. 82, fig. $5 \mathrm{a}$ ). Maxillæ, lobo apicali in duas partes haud diviso, palpi perfecti 6-articulati (fig. 5 b). Palpi labiales, 4 -articulati articulis sensim decrescentibus (fig. $5 \mathrm{c}$ ) abdomen elongato-ovatum apice integrum haud spinosum (fig. $5 \varepsilon$ ). Alarum renx ut in Thyunis disposita vena spuria in cellula lma submarginali fere obliterata. Pedes graciles Inguibus apice hifidis (fig. $5 d$ ).

Faunina, aptcra. Cajut oblongum planum; oculi lateralcs, fero ad angulos anticos positi. Occlli 0 . Antennze fcro in margine antico capitis afixa (fig. $6 a$ ) convolutse. Labrum clypco land absconditum setosum. Mandibulo (fig. $6 a$ ) dente internc ferc ad apicem instructæ, parum curvatix ct vix setose. Maxillm parve palpis gracilibus 4 -articulatis articulo 11110 minimo (fig. $(\mathrm{b} b$ ). Mentum ovale compressum. Labitum omnino retractum, palpi labiales 4-articulati (fig. 6 c) articulo ultimo longiori. Thorax depressus oblnngus 3-partitus, mesothorace parvo; abdomen elongatum depressum apice acıleo cxserto instructum (figs. $6 f, 6 \mathrm{~g}$ ). Pedes ut videtur fossorii, tibiis anticis crassis bicalcaratis tarsi antici articulo basali currato curvatura scrie spinularum deprcssarum instructa (fig. $6 d$ ). Ungues basi dilatati (fig. $6 e$ ).

\section{Sprcies Unica. EIRONE DISPAR, Westw.}

(Platc 82, figs. 5 ô, 6 우.)

Mas. E. Niger nitidus punctatus alis limpidis. Long. corp. lin. $4 \frac{3}{4}$. Expans. alar. lin. 7 . Fromina. Fulvescens tcuuissime punctata. Long. corp. lin. $2 \frac{1}{2}$.

The great diversity between the two insects represented in Plate 82, figures 5 and 6 , and the similarity of the winged individual to the male Thynni, and of the apterous one to the genis Scleroderma, would have made me hesitate in publishing them as the sexes of one species, were I not convinced that entire reliance miglit be placed on the observations of Mr. Fortnum, by whom they were collected at Adelaide, in Southern Australia, and forwarded to Mr. Hope, during the present year. 
The male (pl. 82, f. 5) is entirely black and slightly clotherl with grey hairs, the head is nearly round and strongly punctured; the clypeus but slightly porrected; the labrum pitchy and setose; the mandibles are pitchy red, with the base and apex black; the thorax is oblong, truncated in front and rounded at the metatlorax; the pro- and mesothorax are regularly punctured, but the metathorax is very delicately rugose. The abdomen is sub-depressed, fusiform and thiekly punctured, especially at the base of the segments, the basal segment with a decp longitudinal impressed line: the three following segments are marked with a rather deep transversc impression aeross the basc, and havo a slightly raised space on each side, near the hind margin ; the extremity is destitute of spines or tubercles, the under side is also simple and thickly punctured; the legs and antennæ are slender and black, and the hyaline wings, nearly colourless, but strongly iridescent, with the veins and stigma black.

The femalc (pl. 82, f. 6) is entirely fulvous, the fifth segment of the abdomen alono being of a darker colour; the wholo surface of the body is remotely punctured, the punctures being oblong, but minute; the head is oblong and depressed, with a slight longitudinal impression in front, extcnding to the bifid projection at the sides of which the antenna are placed; the mandibles, unliko those of Scleroderma, arc curved and acutely pointed at the tips, with a sulall tooth on eaeh side, ncar the extremity ; the thorax is rather longer than the liead, the mesothorax being the widest part, the sides of which are swollen; the metathorax is narrowest at the base, and rather slanting. The abdomen is long, entire and uniform, the second segment exhibiting none of the peculiarities of the true Thynni: the legs are short, the posterior femora and tibiæ dilated, the latter furnished on the outer margin with short strong seta, thus differing entirely from the feet of the Sclerodermæ, which are not fossorial.

The plant represented in Plate 83 is the Australian Tetratheca Thymifolia of Smith.

In addition to the various memoirs upon the Thynnides noticed in the previous pages of this work, I have to add that Dr. Ericlison, in lis Memoir on the Insects of Van Diemen's Land, published in the Archiv. fur Naturgeschichte for 1842, has described four additional species of Thynnus, togetlior with a new genus named Ariphron, founded upon an apterous female closely allied to No. XXII.-1st NOYENBER, 1844. 
Thynnus, but having the head twice as broad as the thorax (which is tripartite), the sides of the mesothorax furnished "processu alæformi"); the maxillary palpi 6-jointed, with the joints subæqual, and the tarsal ungues simple. The type A. bicolor is 5 lines long. The following is its specific character given by Dr. Erichson, together also with those of his four species of Thynnus:-

Ariphron bicolor.-Rufus, capite piceo, abdomine nigro apice rufo. Long. 5 lin.

Thynnus Olivieri.-Mas.; niger, pedibns rufis, thorace supra fulvo villoso, abdomine supra 4-, infra bifariam flavo-maculato.

FEN.-Rufa, capite subgloboso thoraceque inımaculatis abdomine piceo, segmentis $1-5$. 4-fariam flavo-maculatis, 1. lavissimo. Long. $7 \frac{1}{2}$ lin.

Thynnus senilis. - Kiger, albido-villosus pedibus concoloribus, clypeo flavo. (Mras.) Long. $5 \frac{1}{\mathrm{~g}}-7 \frac{1}{2}$ lin.

Thynnus fervidus. - Niger, clypco, mandibulis scutelloque flavis, thorace rufo-vario, abdomine pedibusque rufis. (Mas.) Long. $6 \frac{1}{2}$ lin.

Thynnus humilis. - Niger, cinereo-hirtellus mandibulis testaceis abdominis segmentis exolete flavo-marginatis, secundo transrersim bicarinato. (Fem.) Long. $3 \frac{1}{3}$ lin. 


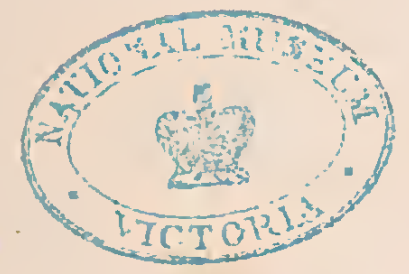

$x^{24}$ 


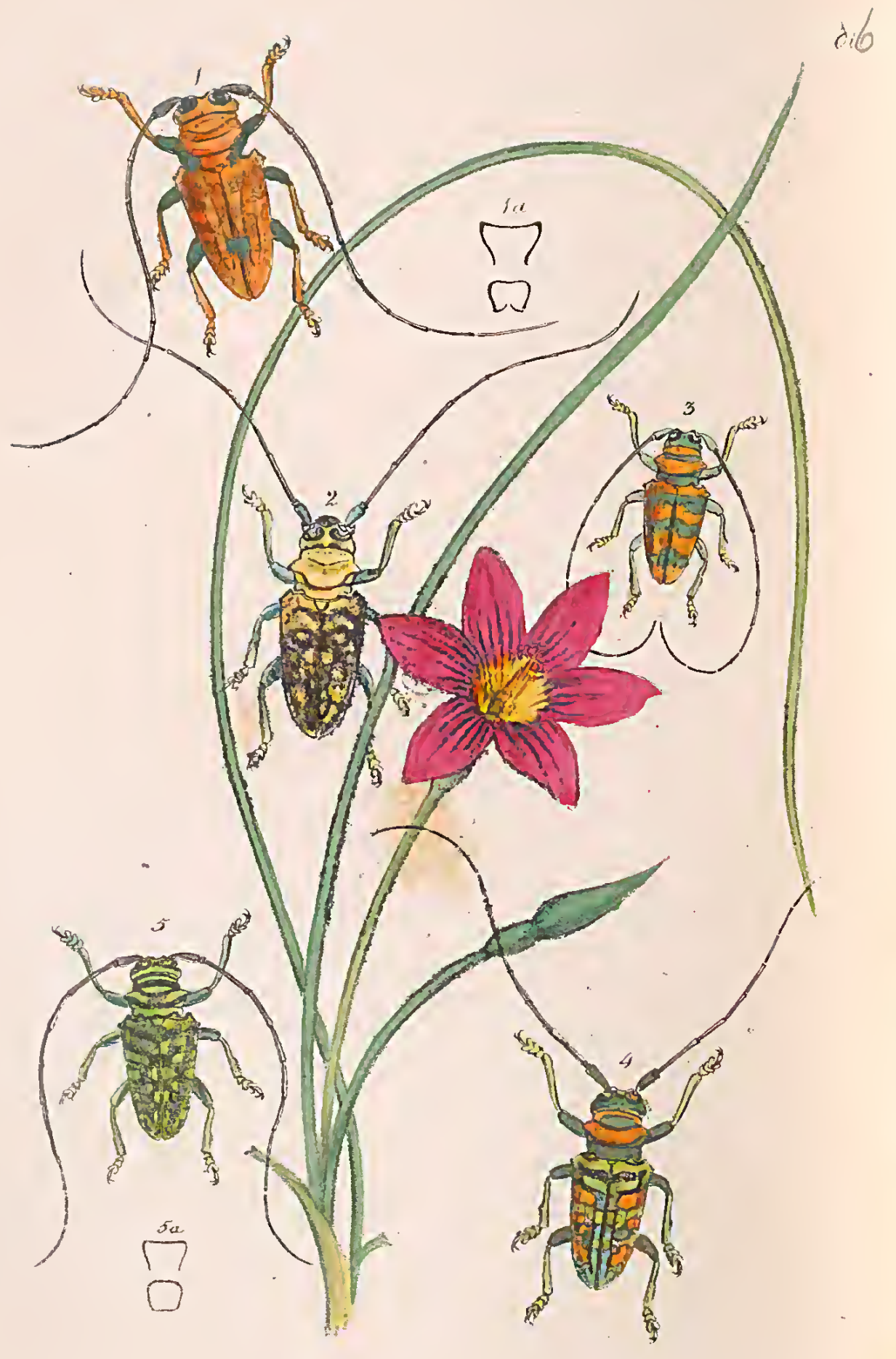

s.t. 

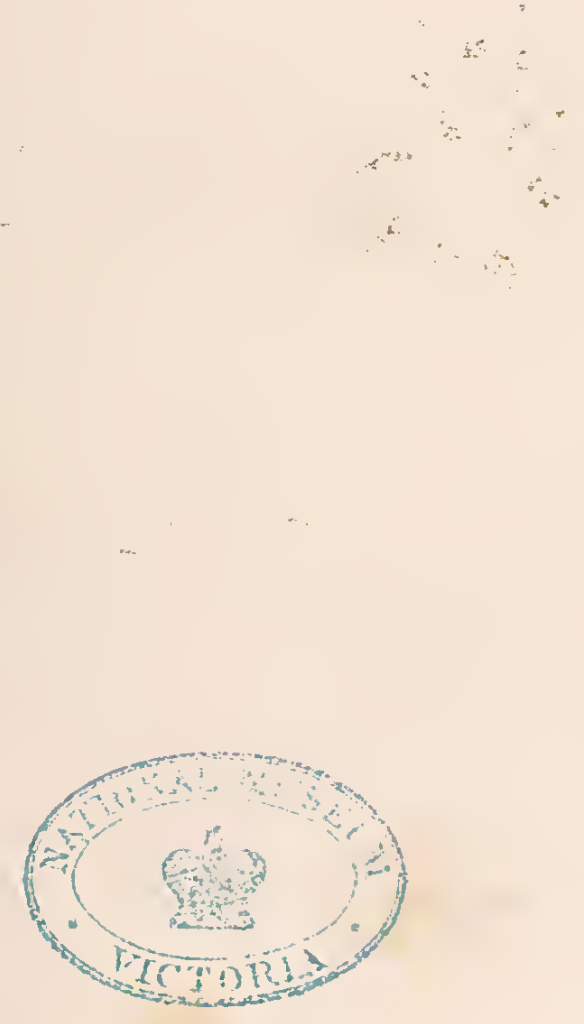

3 


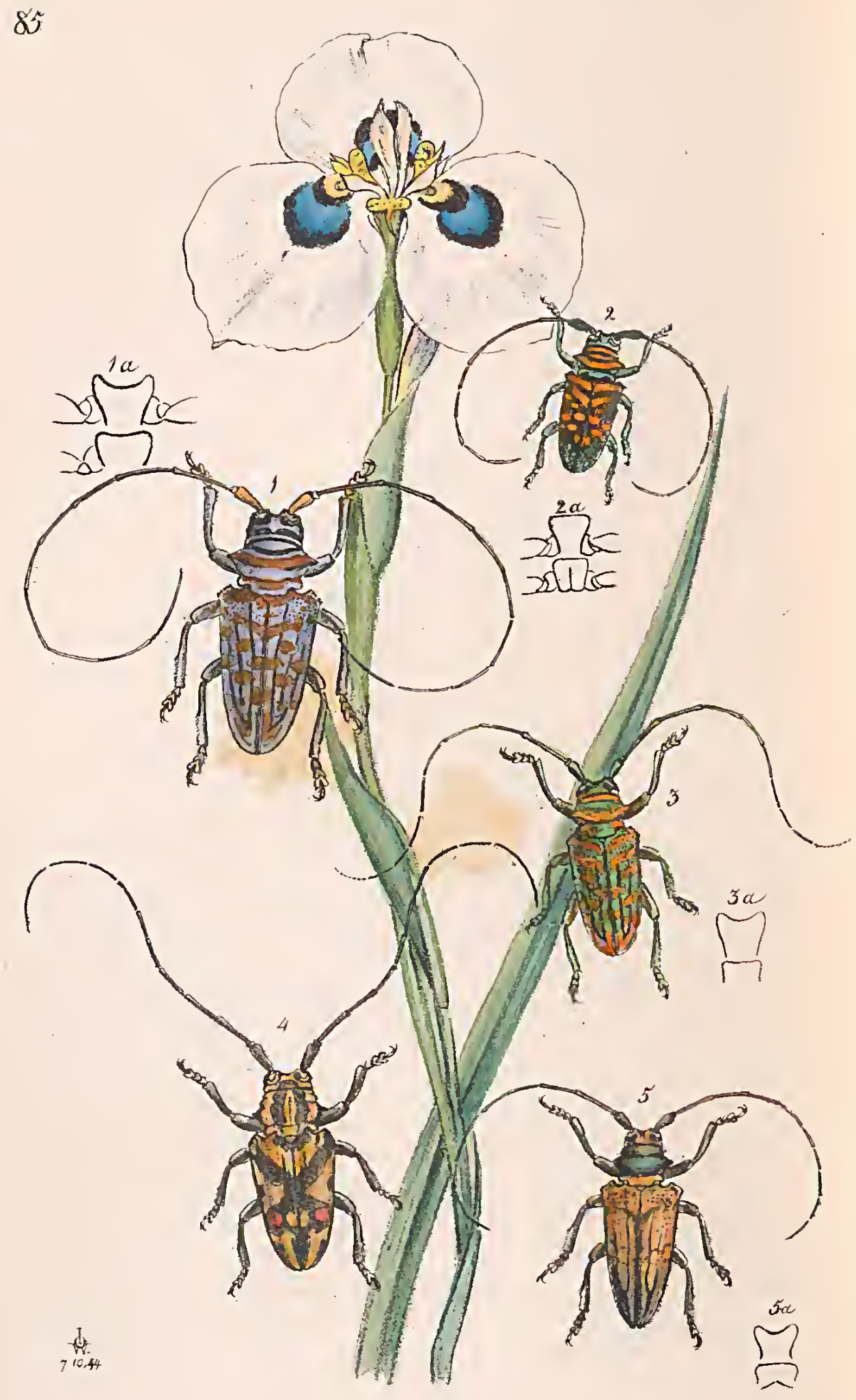



84

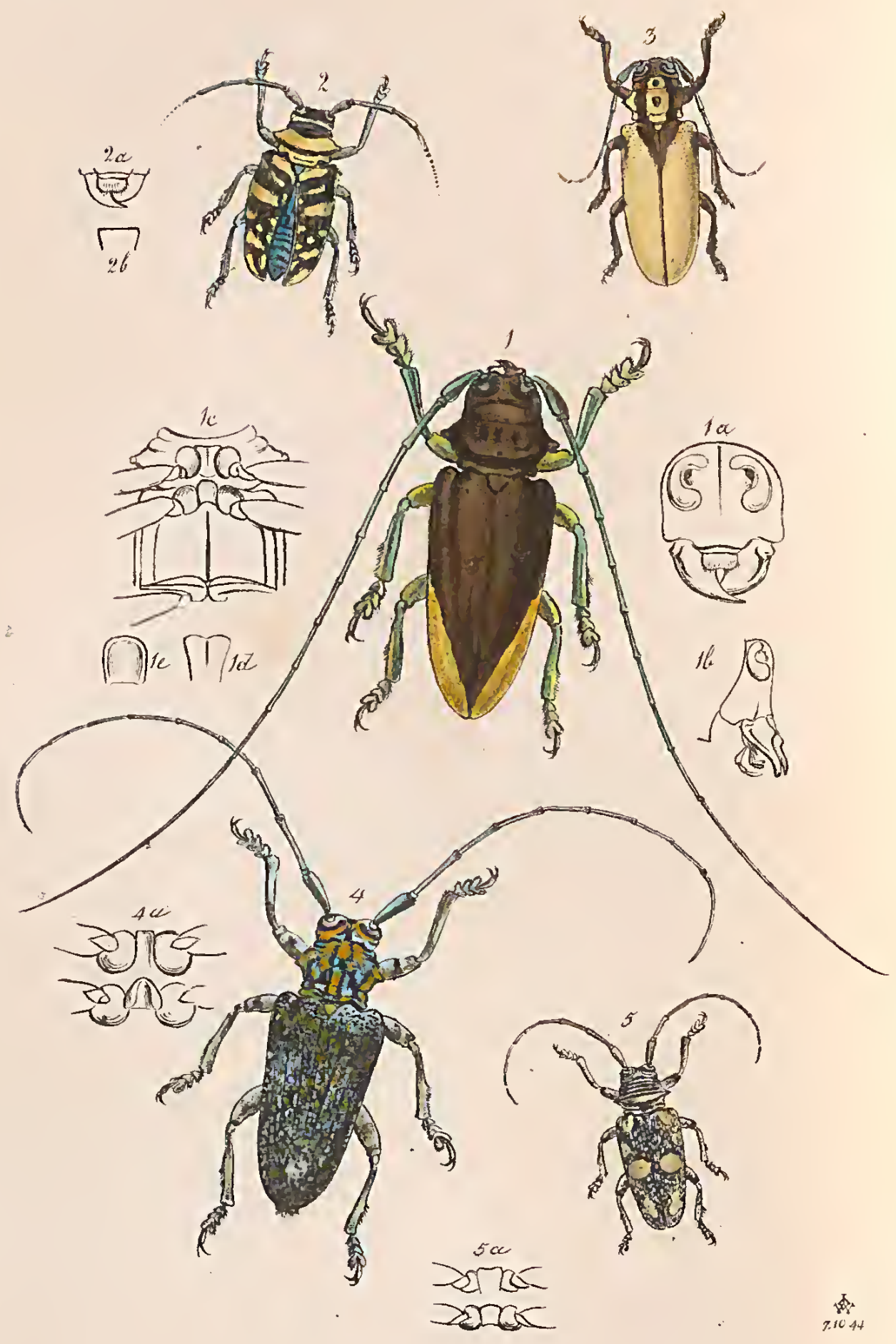




\section{PLATES LXXXIV, LXXXV, AND LXXXVI.} ILLUSTRATIONS OF SOME AFRICAN SPECIES OF LONGICORN BEETLES.

Prevrous to entering upon the descriptions of the species of Longicorn beetles, represented in the accompanying plates, it is proper to make the following observations, with reference to some of the other Longicorns figured in the three plates already devoted to that family in the present volume.

\section{LAMI O BESA. \\ (Plate 6t, fig. 5.)}

This insect, I am informed by M. C. Sommer, Esq., of Altona, is known in the continental collections under the name of Phryneta Dregei.-Klug MSS. As, however, no description of the insect had bcen publishcd, it was impossible for me to have the least idea of its identity with my species, especially as it is given in Dejean's Cataloguc as a native of the Cape of Good Hope. The characters of the genus Phryneta are given in the IIistoire Naturelle des Insectes Coléoptères of the Count de Castelnau, vol. 2, p. 477.

\section{LAMIA PALINII.}

(Plate 74, fig. 2.)

This species appcars to me to be jdentical with the Lamia principalis of Dalmau. Schonl. Syn. lns. l., pt. 3, App. p. 162. Mr. Hope has recently reccived a specimen of it from Cape Palmas.

\section{LA II I COMES.}

(Plate 78, fig. I.)

1s identical with Lamia cornutor Fabr., the typical specimen of which, described by Fabricius, is still preserred in the Cabinet of tho British Mluseum. It is a malc-that representcd in my plate being a female. The locality given by Fabricius of " $A$ merica" is cvidently erroneous, the group to which it belongs beiug confincd to the African continent. II. Dupont is unfortunately unacquainted with the locality of his specimen, it being marked in his collection, MIadagascar, with a point of doubt.

Srx. Lamia cornulor, Fabricius. S. Ent. p. 178. Ent. Syst. 1, pt. 2, p. 292. Olivicr Entomol, 4. Ccramb. pl. 17, p. 132.

\section{LAMIA PRINCEPS. \\ (Platc 78, fig. 2.)}

Is referred by M. Dupont to the genus Zoographus Dcjean, described by Laporte dc Castelnau in the Hist. Nat. Ins. Col. 2, p. 473, but without any notice of the structurc of tho sterna, which forms tbc chicf character of the group.

\section{LAMII (STERNOTOMIS) NORRISII. Westw.}

(Trans. Ent. Soc., vol. I, p. 148, pl. xv. A. Platc 84, fig. 1, and details.)

L. supra opaca nigro-fuliginosa, elytris postice flavo-cinctis, antennis subtus pedibusque birsutie opalina indutis.

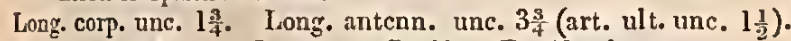

Habitat apud Sicrram Leonam. In Mlus. D. Norris.

The head is black, with the sides behind the eycs of an opaline green colour; the antennæe are very long, 11-jointed, and black, 
with the underside tinged with opaline green. The mandibles are large, and furnished with an angular tubercle near the base on the outside; thcy are black, with the disc opaline green, which is also the colour of the upper lip and palpi. The prothorax is black, with the disk irregular, being marked with two transverse impressions. The scutellum and elytra are black; the latter with the shoulders rather rounded (not obliquely truncate), and the outer margins beyond the middle coloured yellow, dilated towards the apex. The abdomen is golden-coloured above, and black beneath, except the two basal segments, which are yellow. The prosternum is rather prominent and dilated, sub-truncated, (fig. $1 d$,) and the mesosternal process is also slightly prominent and rounded in front. The underside of the whole of the thorax is yellow; the legs are black, the upper side of an opaline green, and the under side of the coxæ and femora yellow.

Notwithstanding the great length of the antennæ, and especially of the last joint of those organs, in the unique specimen hitherto known of this species, indicating the malc sex, the slight toothing of the mandibles, and moderate size of the sternal processes, are remarkable. (Fig. $1 a$, the head, seen in front; $1 b$, the -same, sideways; $1 \epsilon$, the thorax beneatli.)

\section{LAMIA (STERNOTOMIS) CRUX NIGRA. Hope. ,}

(Trans. Zool. Soc. 1, p. 104, pl. xv. fig. 2. Plate 85, fig. 4.)

L. straminen; thorace nigro, vittis tribus Iuteis; elytris macula cruciformi nigra alterisque duabus rotundatis aurantiis.

Long. corp. lin. Il, Lat. 4.

Ha bitat in Sicrra Leone, D. Palin. In Mus, D. Hope.

This lovely species has the antennæe very long, and 11-jointed, the terminal joint being but moderately elongated; they are black above, and light grecnish grey beneath. The head is black, varied with luteous, and with two golden-coloured spots beneath the eyes. The thorax is black, with a golden-coloured spot on cach side, and a central and two lateral luteous vittæ, the dorsal one being interrupted in front, and ending before the scutellum, which is concolorous. The clytra are pale straw-coloured, variegated with lemon and dark and light orange tints, and marked with a large black (St. Andirew's) cross, haring two red and two pale buff spots. The body beneath is unicolorons; and the feet are black above, and grey beneatl. 


\section{L.MIIA (STERNOTOMIS) IMPERLALIS, Fab.}

(Plate 86, fig. 3.)

L. thorace spinoso, fcrugineo villosa, viridi-fasciata; antennis longis atris, capite villoso ferrugineo obseure liueato, orbita oculorum viridi, thorace striga media impressa fasciaque postica viridi; clyttris villoso ferrugineis fasciis duabus, nnteriore reeta, media e maculis tribus quadratis concatenatis, punctoque postico, viridibus; pedibus ferrngineis.

Srx. Lamia imperialis, Fabricius; Syst. Elcuth. 2, p. 286.

Cerambyx luteo-obscurus, Voct, Col. EA. Panz. iii, p. 20. 19. tab. 7. f. 19.

Ceramlyx ornatus, Olivier Entomol. Ceraub. pl. 4, fig. 21 c.

Lamia bifasciana, Fabr. Ent. Syst. 1, p. 281.

Fabricius suggests that this insect may be a possible variety (nuper declaratum) of his L. regalis; but that species is abundantly distinct, not only in its markings, but also in its longitudinally multi-striated elytra and the rounded humeral angles.

The Fabrician description abstracted above accords exactly with a specimen from Guinea, received by the Rev. F. W. Hope from Mr. Westermann, whose residence at Copenhagen enables him to determine the identity of those Fabrician species which were described, (as was the case with the one before us,) from the collection of M. Selestedt. This specimen is represented in my. pl. 86, fig. 3. It is a male, and las tho mandibles armed with a strong, rather deflexed spine in front noar the base, the outside of the mandibles being green, and the remainder black. The middle of the facc and labrum are fulvous, the former with two rather broad green bars extending from the baso of the antennæ to the mouth; the sides of the head behind the eyes are also green; there is a diamond-shaped fulvous patch on the niddle of the crown, the hind part of the head being green; the prothorax is fulvous, with a slender green transverse fascia across the anterior part, and the hind part of the prothorax, including the spaces behind the lateral teeth, are also green. The humeral angles of the elytra are very prominent, and angularly truncate; the anterior green fascia is, as it were, divided into two parts by a slaty-green stripe, and the three green spots forming the central eurved fascia are margined with dark slaty green; besides the spot in the middle of each elytron towards the extremity, there is a little green patch next the suture, which is itself also green. The feet are green, vith the undersides more golden.

I possess two beautiful varieties of this species, one in which the green markings are of a bluer hue, and separated from each other by, or margined with, black lines; and the other in which the ground colour of the insect is of a browner fulvous colour, and the 
green markings of a golden hue, destitute of the black or slatecoloured cdges. The fect are also of a more golden fulvous colour. Both are females. The latter of these specimens was presented to me by J. A. Turner, Esq., of Manchester.

The Fabrician L. bifasciata, described from the British Museum cabinet, is identical with L. imperialis. The locality of Jamaica must therefore be considered as erroneous.

\section{LAMIA (STERNOTOMIS) MIRABILIS.}

(Plate 86, fig. 5.)

L. thorace spinoso, nigra, elytris antice fasciis duabus, postice punctis, (8 vel 9 in singulo) viridilus, elytris basi mucronatis.

Long. corp. lin. 9-11.

Habitat the Gold Coast, Afr, tropic occident.

Srx. Cerambyx mirabilis, Drury Ill, vol, 2, pl. 3I, fig. I. and Append. vol. 2.

Cerambyx pulcher, Fabr. Ent. Srst. I, pt. 2, p. 269. Syst. Eleuth. 2 p. 285. Schonherr. Syn. Ins. 1, part 3, p. 372 . Olivier Entomol, Ceramb. pl. 22, fig. I6\%. Siernodonta prasina, IIope MSS.

This handsome species is varied with black and sericeous green or golden green colours, the latter forming very distinct marks. The face is grcen, marked on each side with an obliquc black line from the base of the antenne to the basc of the mandibles; there is also a black line extending from the under side of the eyes to the sides of the mouth; and also a narrow green fascia across the crown of the head. The thorax is marked with three green transverse fascia, the middle one being the broadest and curved, there being an additional slender abbreviated green fascia within the open space formed by this curre; thcre are also two green spots behind the lateral teeth of the prothorax. The elytra are marked at the base with a transverse green fascia, behind which is a rather broader and more oblique one, slightly interrupted near the lateral margins, and followed by about nine equi-distant and nearly equal sized green patches, of which the two anterior and lateral, and the two apical ones are sometimes more or less confluent; the hinder ones being more or less irregular. The malc (represented in the plate) differs from the female, in laving a much broader head, large dentated mandibles, and longer antennæ, the tips of the joints being more nodose.

\section{LAMIA (STERNOTOMIS) PULCHRA.}

L. nigra thorace transverse fulro trifasciato ; elytris fulvo maculatis et variegatis maculis interdum viridi cinctis.

Srs. Cerambyx pulcher, Drury Ill. vol. I, pl. 32, f. 6, App. C., vol. 2 ; nec Lamia pulchra, Fabr.

Lamia blanda, Schonh. Syu. Ins. I, iii., p. 373. 
Although Drury gives Jamaica as the habitat of this species, there can, I apprehend, be very little doubt of its being a native of Tropical Africa. He describes it thus :-

"Head orange-coloured, encircled with black stripes; antennæ black, being a little longer than the insect; thorax orangecoloured, encircled with black rings, having a single spine on each side; elytra with orange-coloured clouds and spots on them separated by black partitions, some being margined witlı green; abdomen orange-coloured, the middle being dirty green; femora simple, dark green; tibire the same." From Drury's figure it appears very closely allied to L. mirabilis and ornata, if, indeed, it be not a local variety of those insects.

\section{LAMIA (STERNOTOMIS) ORNATA.}

L. nigra fasciis maculisque fulvo-aureis ; capitis thoracis et elytrorum nuargine posteriori, parteque femorum superiore, viridi nitentibus.

Syx. L. ornata, Olivier Entomol. Ceramb., pl. 4, f. 24 a; Pal. Beauv, pl. 37, f. 1. An Ceramb. pulcher, Drury?

The description given by Olivier of his L. ornata from Africa, is as follows, and very nearly accords with the figure given by Drury of the preceding insect:-

"Cer. regalis affinis. Corpus nigrum pulvere fulvo-aurato, fere omnino tectum. Mandibulæ magnæ exsertæ, basi et anterius dente valido armatæe, apice nigræ basi rufæe medio virides. Lineis duabus nigris ab oculis ad mandibulas. Oculi viridè circumscripti præcipue postice. Thor'ax rufus, postico ad latera viridis fasciis duabus nigris. Elytra rufa fasciis nigris numerosis anastomosantibus viridi marginatis. A pex elytrorum et sutura postice viridia. Corpus infra rufum carina abdominalis et pars superior femorum virides, apophysis trapezoidalis (prosternum) inter pedes anteriores."

The Rev. F. W. Hope possesses an old faded specimen from Lee's Cabinet, labelled L. pulchra, which agrees with Olivier's description and figure $24 \mathrm{a}$, and which miglit be regarded as a specimen of L. mirabilis, in which nearly the whole of the green markings had assumed a fulvous hue.

The insect represented in Plate 84 , fig. 2 (not bcing in a fully developed state), from the collection of $\mathbf{M}$. Chevrolat, of Paris, is regarded by that entomologist as a variety of $\mathrm{L}$. ornata, in which the fulvous colour of the typo is replaced by pale buff, or straw colour, and the black interstices are tinged with blue instead of green. The body bencath is greatly varied with pale and dark 
buff, and with blne and black colours. The markings of the elytra may be traced to those of L. olnata and its immediate allies, the second fascia being more attenuated and interrupted than usual, and the intermediate patches rather smaller than ordinary. It was brought from Pauz Oasis by M. Cailleaux.

The insect represented in Plate 86, fig. 2, from the collection of the late A. H. Haworth, Esq., appears to me to be another fine variety of L. ornata, having the thorax and markings on the elytra very pale buff; and the sides of the former, behind the lateral spines, and the ground colour of the latter, of a bluishgreen colour; the dark stripes separating the fascix at the base of the elytra being much reduced in breadth. The specimen is a male, having the mandibles dentated at the base, as in the other allied insects.

It appears also probable that the Cerambyx marmoratus of Voet Coleopt. Ed. Panz. 3, p. 21, 20, pl. 7., fig. 20 (Lamia venditaria, Sch. Syn. Ins. 1, pt. 3, p. 373), the locality of which was unknown, is another variety of $L$. ornata. It is represented as of a fulrous colour; the thorax banded with black, and varied with greenish at the sides, behind the lateral spines, and with the elytra varied witl numerous irregular black markings.

LAMIA (STERNOTOMIS) AMABILIS, Hope MS.

(Plate 86, fig. 4.)

L. humeris elytrorum augulato-truncatis, nigra viridi fulvoque tomentoso ornata ; thorăce rufo-fulvo, postice viridi; elytris fasciis maculisque rufo-fulvis argenteo-viridibusque notatis. Long corp. lin. 11.

Habitat Ashantee. In Mus. D. Hope.

This highly beautiful insect is most probably but onc of the varieties of the type of the genus which is distinguished by the angnlated shoulders of the elytra, all of which (inclinding several of the following insects) will ultimately, in all probability, be determined to constitute one extremely variable species, the local varieties of which preserve an uniformity in the distribution of their colours. Thus, L. chrysopras, from Aquapim, las the general colour dark fulvous, with a single green patch on the elytra, and the other dark markings almost obliteratẹd; L. ornata, in like manner, has but very little green colour visible; whilst L. mirabilis is entirely green and black. The chief characteristic of all these varieties seems to be the three spots on the middle of each elytron, arranged somewhat in a triangle; and 
these we find also in L. imperialis and even in L. aper, in which the basal fasciæe are but indistinctly marked.

The male of tho inseet now before us has the face fulvous-red in the middle, with the lateral and hind parts, and the labrum, green; the prothorax is fulvous-red in front, and silvery-green behind, the former part with three black, slender, transverse fascia, the third being curved. The basal fascia of the elytra is green; the next one (interrupted near the sides) is also green, but varied witl fulvous; the third is broad, lateral, and fulvous; the three central oval patclies are distinct, the inner one green, and the two outside ones fulvous; the suture bcyond these is also marked with two silver-green patches, placed consecutively, the second communicating witl a small subapical angulated fulvousgreen spot, which is preceded by a large fulvous patch; the spaces between the fulvous lateral patches are also tinged with green; the femora and underside of the body are also grecn; the middle of the abdomen with a row of black spots.

The female is mucli more strongly marked with fulvous-red colour, especially at the sides of the elytra, which are almost concolorous, the green being here restricted to the base and middle portion of the suture; but all the markings are in their ordinary position.

\section{LAMIA (STERNOTOMIS) FERRETI, Reiche MS.}

(Plate 85, fig. 1.)

L. grisea, thorace ét elytrorum basi lutco fasciatis, his postice Inteo-maculatis. Long. corp. lin. 14. $\hat{\delta}-11$ o .

llabitat. in Alyssinia. In Mus. Reiche et Hope.

This insect entirely agrees in its general characters with L. ornata and its allies, but is distinguished by its Eastern locality and peculiar coloration. The face is black with a dirty fulvous stripe down the middle, and an oblique one on cach side, cxtending to the base of the mandibles, which are armed with a large obtuse tooth at the base in front. The labrum is fulvous, as is also the crown of the head, the hind part of which is black. The thorax is of an ashy leaden colour, with the antcrior margin, transverse curved fascia across the middlc, and a subapical fascia, of a dirty fulvous colour. The elytra are of the same ashy leaden colour, rough at the base, where they are marked with a rather broad dirty fulvous fascia, followed by a narrower one (interrupted near the sides), and. belind this are about nine patches of the same fulvous colour. The: 
mesosternum is also fulvous, with a broad oblique greenish blue stripe on each side, and the abdomen is black, with a fulvous patch on each side.

LAMIIA (STERNOTOMIS) TARGAVEl, Reiche MS. .

(Plate 85, fig. 2.)

L. aigra prothoraco fulvo nigroque fasciato, postice viridi, elytris basi fulvo bifasciatis, postice uaculis 7 fulvis alterisque duabus subapicalibus viridibus. Long. cerp. lin. $8 \frac{1}{2}$.

Habitat in Guinea. In Mus. D. Reiche, D. Targcau.

In all important respects this insect agrees with L. mirabilis, except that the thorax (except the hind part) and the major part of the markings of the elytra are fulvous. The face is black, with an elongate conical fulvous patch down the middle, extending upwards and between the antenne at the base, the labrum and extremity of the clypeus being green. The eyes are margined before and behind with greeu, the front margin dilated below into an orange green oblique patch extending to the base of the mandibles, which are slightly cornuted near the base in front, and orange green at the sides of the base. The head above is marked with a fulvous patch in the middle of the crown, and the hind part is dark green. The prothorax is fulvous in front with three black stripes, and the hind part is silvery green. The elytra are black, the humeral angles and apical part irrorated with green, which is also the colour of the two subapical spots; the two basal fascire and the other spots, seven or eight in number, being dark fulvous. The. mesosternum is marked with an orange patch at the side, and the metasternum is green in the middle, changing to fulvous at the sides, each side marked with a black streak; the abdomen is black, each segment with a large transverse orange green patch on each side.

LAMIA (STERNOTOMIS) BOHEMANNI, Chevrolat MS.

(Plate 85, fig. 3.)

L. humeris elytrorum angulato.truncatis ; supra viridis maculis fasciisque ferrugineis (marginibus pallidioribus) notata. Lotig. corp. lin. 11.

Habitat Port Natal, Africa Austral. In Mus. D. Chevrolat et Parry.

This insect is most remarkable for its locality, showing that this group of insects enjoys a very wide geographical range in the African continent. The upper surface of the body is of a dark opaquo green colour, varied with ferruginous fasciæe, and spots arranged as in the allied species; the edges of which being of a rather lighter testaceous colour, give a varied appearance to the 
insect. The face is black, except a conical slender fulvous line down the centre, broadest next the labrum, which has the front also fulvous. The mandibles are large, with a moderate sized deflexed acute spine in front at the side of the base. The head above has a ferruginous streal belind the eyes. The front margin of the prothorax, a broader central fascia, and a slender subapical one interrupted in the centre, are of a ferruginous colour, as are also the two basal fascia, and about nine spots on eacli elytra occasionally partially confluent, the apical one acutely angulated. The metasternum is fulvous, with two grcen spots at each side, and the abdomen is fulvous, with the sides green and centre black.

\section{LAMIA (STERNOTOMIS) CHRYSOPRAS.}

(Plate 86, fig. 1.)

L. fulva, lateribus prothoracis (pono medium) seutello femoribus guttisque duabus suturalibus el trorum argenteo-viridibus, his obscurius faseiatis. Long. eorp. lin. 12.

Habitat. Aquapim, Guinea. In MIus. Hope, \&c.

Sys. Cerambyx chrysopras, Voet Coleopt. Ed. Panz. 3, p. 21, 22, tab. 9, fig. 22. Schonh. Syn. 1, pt. 3, p. 373.

Sternodonta Robillardii, Dupont XISS.-Dej. Catal. 2nd Ed. p. 342.

Although this insect appenrs at first sight so entirely distinct from the preceding species, I must confess it is with doubt that I retain it as distinct, for although the prevailing colour is fulvous, yet in various parts we see little touches of silvery green, indicating the more ordinary dispositions of that colour. The clytra also, when examined, are found to liave the black or green markings of the preceding species clearly distinguishable, although so thickly irrorated with fulvous as at first sight to appear merely as indistinct cloudings over the elytra. The body beneath is elegantly varied with fulrous and silvery green.

\section{LAMIA (STERNOTOMIS) DLCALIS.}

(Plate 85, fig. 5.)

L. nigra thorace lateribus virescentibus, posticeque subluteis; elytris postieo attenuatis lutescentibus, nebulis virescentibus apieibusque nigris. Long corp. lin. 12.

Habitat in Gambia. In Mus. Dupont.

Syn. Lamia ducalis, Klug, in Erman's Reise, tab. xvi., f, 4.

Sternolomis aper, Pcreheron Gen. des Insectes Col., pl. 16.

The face is black, and both the labrum and base of the mandibles, and a triangular patch on the clypeus (bearing an interrupted, slender, black, median line), fulvous, and witl two fine short green lines between the eyes. The liead above is dirty buff, with the lind part black; the prothorax is black and slining in front, witl a green tinge at the sides, behind the lateral spines, 
and the hind part dirty buff. The elytra are considerably attenuated towards the apex; they are of a dirty fulvous colour, slightly varied with greenish, which colour forms an oblique fascia towards the base, and two or three obscurc ocellated markings across the middle, placed obliquely, the apex of the elytra being black. The legs are greenish-black, with the tibia and tarsi dirty buff and green; the sides of the metasternum are marked with a large patch of bright fulvous scales, extending in front to the hind edge of the sternal process; the sides of the abdomen are also marked beneath with a sericeons-green patch.

\section{LAMIL (STERNOTOMIS?) NIVEISPARSA, Chevr. MS.}

\section{(Plate 84, fig. 5.)}

L. nigra, albo farinosa; thorace fasciis $\mathbf{6}$ transversis niveis; elytris niveo-punctato-striatis maculisque quatuor niveis, tertia majori.

Long corp. lin. 10.

Habitat Port Natal. D. Bohemann. In Mus. Cherrolat.

The head is of moderate size, with the mandibles small, and not crossing each other at the tip; the fuce is white, with slender black lines, which extend upwards between the antennæ; the lind part of the liead above is black. The prothorax is black, with six slender, white, powdery, transverse fascire, the fiftl of which is abbreviated, in consequence of the eurved raised part of the prothorax extending between the lateral spines; tho elytra are rounded at the humeral angles, and the disc is covered with a number of longitudinal stria, formed of small oblong white dots, in addition to which each is marked with four white spots: the first is round, and at the base in the middle; the sceond is also round, and at the side about one-third of the length of the elytra from the base; the third is large and round, being placed nearly in the middle of the elytra; and the fourtl is subtrilobed, and placed near the extremity. The legs are black, covered with white powder; the thighs black at the tips; the body beneath is covered with white powder ; the sternal processes are of comparatively small size (fig. $5 a$ ).

This species agrees with Lamia regalis, Fabr., in the simple humeral angles and punctate-striate dise of the elytra, as well as in the comparativo smallness of the sternal processes, and the spots of the elytra. In several of these respects, indeed, it approaches the sub-genus Zoographus, with which it appears to form the conneeting link. 
LAMIA (ZOOGRAPHA) IRRORATA.

(Plate 84, fig. 4.)

L. thorace spinoso fusco ferrugineoque vario; elytris nigris ferrugineo irroratis; antennis cinerascentibus, pedibus griseo luteo nigroque variegatis. Long. corp. ố lin. 18.

Habitat in Sierra Leonc. Mus. Hope et Reg. Paris.

Sxs. Lamia irrorata, Fabricius, Ent. Srst. 1, pt. 2, p. 270 ; S. Eleuth., 2, p. 286 ; Schonl. Syn. Ins., 1, pt. 3, p. 373 .

Cerambyx mebulosus, Voet Coleopt. Ed. Panz., 3, p. 20, 18, tab. 7, f. 18.

This species is black, clothed with a greyish powder, and thickly irrorated with dirty fulvous dots. On the crown of the head are tro small triangular dark patches, and the hind margin of the head is black; the mandibles of the male are small, black, and unarmed; the dise of the prothorax is rugose and grey, with numerous small dirty fulvous marks; the elytra are closely covered with minute punctures, and numerous irregular small fulvous dots, in addition to which each is marked with the three ordinary, slightly elevated, polished, black, longitudinal lineolæ; the legs and underside of the thorax are variegated with luteous black and grey; and the abdomen is grey, with the centre black, ench segment, except the last, being marked on each side with a small fulvous patch.

\section{LAMIA (TRAGOCEPHALA ?) GLAUCIN $\Lambda, D e j$.}

L. obscure fusen opaca ; thorace stiiga lata media maeulisque duabus lateralibus ; elytrisque (plaga magna basali triangulari exeepta) pallide flaveseentibus. Long corp. lin. $13 \frac{1}{2}$. Habitat ? ? In Mus. Cherrolat (olim Olivierii).

This pretty species is nearly allied to Lamia angulata of Olivier, and L. bicolor (W. ante, pl. 78, fig. 4). It is on this account that I presume it to be an African species, differing cliefly from the last-named inscet in its less robust form and shorter antennæ, which might indicate it to be the female of that species; but the pale markings on the thorax, and the large triangular dark patch on the base of the elytra, must, I conceive, be regarded as indicating a distinet speeies. The general colour is opaque dark blackish-brown; the markings on the thorax and the elytra (except the basal patch and the small lateral streaks) are of a rery pale yellow colour, having a greenish tinge.

Obs. Lamia humeralis, Fabricius, Ent. Syst., 1, part 2, p. 281, appears also to belong to the sub-genus Sternotomis.

The plant represented in Plate 85 is Iris pavonia, and that in Plate 86 is Trichonema roseum, both from Southern Africa. 
I take the opportunity of a spare page to mention a work now in course of publication in France, especially worthy of the attention of English Coleopterists, the title of which is as follows:-

Histoire Naturelle des Coléoptères de France. Par M. E. Mulsant. 8vo. 1839-1844, with Plates.

Livraison 1. LoNGiconnes (1839), pp. 304,3 pl.

"2. LAMELLicornes (1342), pp. 623, 3 pl.

"3. PaLPicoRnes (1844), pp. 196, 1 pl.

This work is one of the most carefully executed productions hitherto published in France upon the insect tribes. Unlike the majority of entomologists, the author has not confined limself to giving very detailed descriptions of the insects in their perfect state, and to the difficult unravelment of their synonymy, but has investigated their structure with great minuteness and precision, and has especially studied their preparatory state, sexual distinctions, and specific variations, whereby he has considerably reduced the number of supposed species. Sucl a work, from an author residing far from the French metropolis, and accordingly free from those incitements to increase the number of species (which it is to be feared is one of the results of rivalry in Natural History), and exercising his talents upon the insects of his locality, may be well conceived to be a production of real zeal for the science-a true labour of love. The plates are drawn and engraved with great delicacy, although it may be objected that the anatomical details are too small. It will be sufficient, in order to afford an idea of this work, to give the following abstract of the last livraison. After an introduction of 23 pages, the author divides the Palpicornes into two groups - the Hydrophilides and Geophilides :-

1. HYDROPHILIDES.

FAM. 1. Sperchéens. 1 G. Spercheus. 1 Sp.

FAM. 2. Helophoriens. 2 G. Helophorus. $8 \mathrm{sp.} 3$ G. Hydrochus. 5 Sp. 4 G. Ochthebius. $11 \mathrm{Sp}$. (including the Enicoceri.) $5 \mathrm{G}$. Hydrana. $7 \mathrm{Sp}$.

FaM. 3. Hydrophiliens. 6 G. Limnetius. 4 Sp. 7 G. Berosus. 4 Sp. 8 G. Hydrophilus. $1 \mathrm{Sp} .9 \mathrm{G}$. Hydrous. $2 \mathrm{Sp} .10 \mathrm{G}$. Hydrobius. $3 \mathrm{Sp} .11 \mathrm{G}$. Laccobius. $1 \mathrm{Sp} .12$ G. Helophilus, n. g. I Sp. (H. lividus.) 13 G. Philhydrus. 2 Sp. 14 G. Cyllidium. Erichs. I Sp.

2. GEOPHILIDES

Fas. uxics. Spheridiens. 1 G. Cyclonotum. I Sp. 2 G. Spharidium. 2 Sp. 3 G. Cercyon. 15 Sp. 4 G. Pelosoma, n. g. 1 n. Sp. 5 G. Megasternum, n. g. 1 Sp. C. boletophagum, Steph. 6 G. Cryptopleurum, n.g. I Sp. Sph. atomariun, F. 


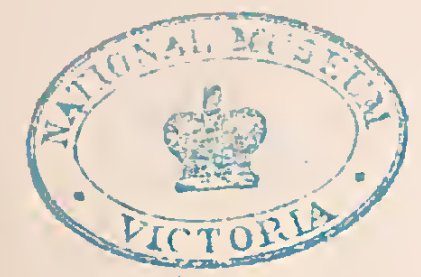




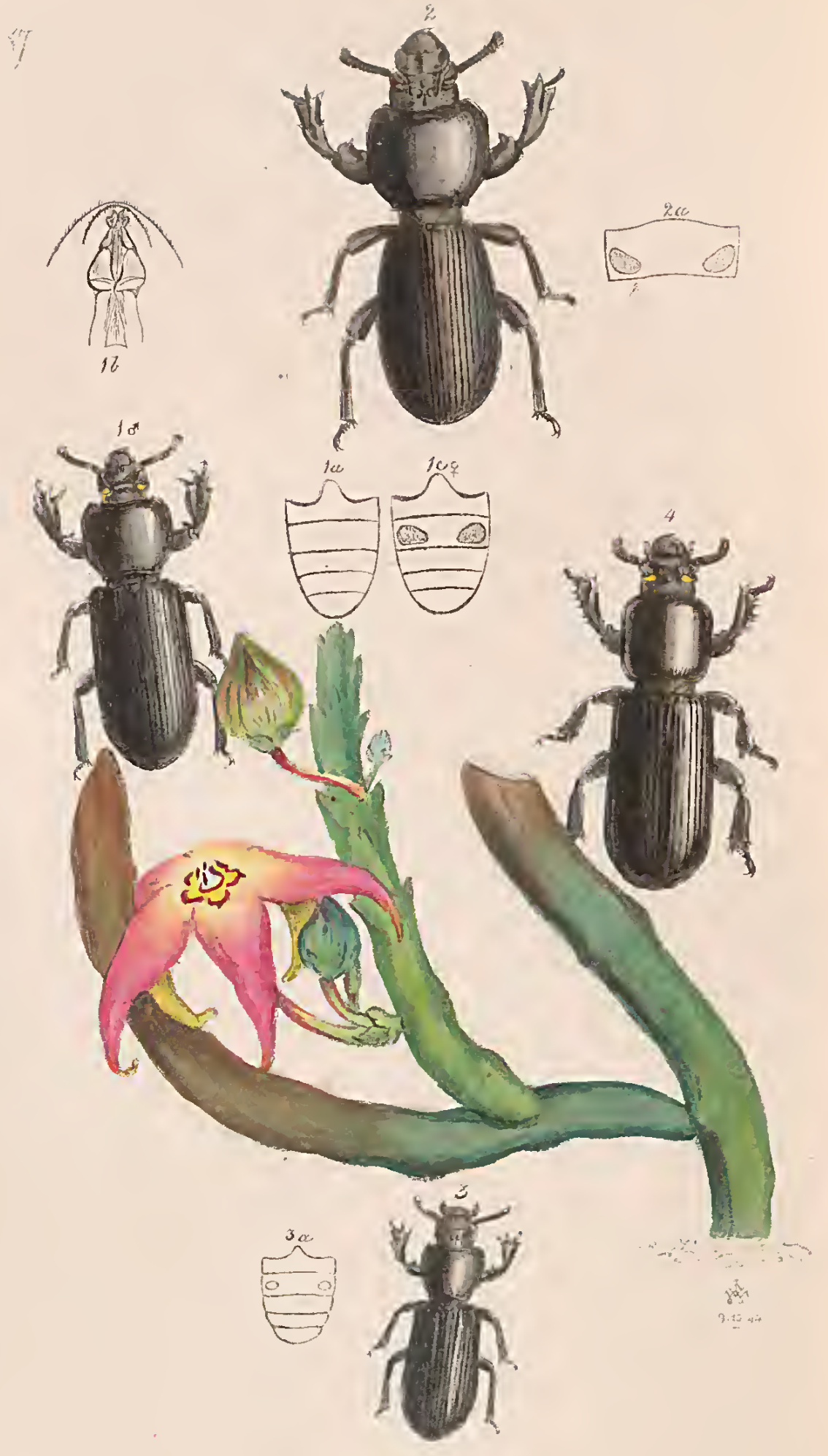




\section{PLATE LXXXVII.}

ILLUSTRATIONS OF FOUR SPECIES OF THE GENUS CIIIROSCELIS.

ChIRoscelis, Lamarck, Anv. n. Miss. mi., p. 260.

THis genus was established for the reception of an insect respecting whose native country there is some doubt, Lamarck stating, "Ce coléoptère habite vraisemblablement dans la Nouvelle Hollande, car il se trouvait parmi ceux de cette contrée que le Capitaine Baudin a enroyés par le vaissean le Naturalıste;" and Latreille states of it, "Habitat in Australasia; insula Sta. Maria, Dom. Pcron, Lesueur," adding (Gen. Cr. ii. 14t), "Speciem alteram priori fere similem at paulo minorem et maculis abdominalibus nullis ex Africa attulit Peron." Lamarck's insect is stated by him to have been "un peu plus de 4 centimcttres (un pouce et demi) de longueur," and his figure " de la grandeur naturelle," represents an insect 20 lines long. On this account, and especially as a species of the genus has now been detected in the south-east part of Africa, it is probable that Lamarck's species is distinct from the following:-

\section{CHIROSCELIS DIGITATA, Fabr.}

(Plate 87, fig. 1. ô.)

C. nigra nitida elytris parallelis, tibiis posticis inermibus, maculis abdominalibus subovatis. Long. curp. lin. 18.

Habitat in Guinea, Sierra Leonc, \&c. Mus. Wcstw., \&c.

Syn. Tenebrio digitatus, Fabr., Syst. EIcnth. 1, p. 145. (Excl. Syn. T. fossor. in Mus. Banks, qnod ad genus Zabrum revocandum.)

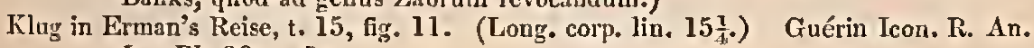
Ins. PI. 30, t, 5 .

Ample details of the structure of this species are giren in my paper on the African Tenebrionidre, published in the third volume of the Transactions of the Zoological Society; in addition to which, it is to be observed that a dissection of both linds of individuals of this species-namely, those possessing and those destitute of the lutcous sericeous patches on the underside of the second segment of the abdomen, has proved that the suggestions which I made in my Introduction to the Modern Classification of Insects, vol. i. p. 320, 322, as to the sexual distinctions of these individuals (founded on their analogy with other Melasomata) were corrcet, the specimens destitute of the patches being males; one of these individuals is represented in fig. 1 ; fig. $1 a$, being the figure of the underside of the abdomen; and fig. $1 b$, the male sexual 
organs in situ: whilst fig. I c, represents the underside of the abdomen of the female.

CHIROSCELIS BIFENESTRELLA, Westw.

Transactions of the Zoological Society, vol, iii. p. 209, Plate xiv. figure 2.

(Plate 87, fig. 3, 3 a.)

C. nigra nitida capite parum rugoso, mandibulis miuus dentatis quam in præcedenti, elytris parallelis, abdominis maculis dunbus minutis rotundatis, margineque antico pronoti haud puncto notato, tibiis 4-posticis fere rectis, apicibus intermediarum subdilatatis. Long. corp. lin. 14.

Habitat in Guinea. Mus. Nost. D. Raddon.

CHIROSCELIS AUSTRALIS, Westw.

(Plato 87, fig. 2, $2 a_{\text {. }}$ )

C. nigra nitida ; capite supra rugoso (vertice sub-trituberculato) prothoracc lato postice punctis duobus fere ad angulos posticos impresso, elytris elongato-ovatis punctato-striatis, tibiis anticis palmatis, posticis $\mathbf{4}$-subrectis simplicibus, abdominis maculis duabus ventralibus fero semicircularibus, femoribus anticis spina basali altcrisque duabus subapicalibus. Long. corp. fere unc. 2.

Habitat in Africæ Orient-Australis partibus interioribus. In Mus. D. Melly.

This fine addition to the genus is unique in the collection of A. Melly, Esq., to whom I am indebted for an opportunity of presenting a figure and description of it to the entomologist.

\section{CHIROSCELIS PASSALOIDES, Westw.}

Transactions of the Zoological Society, vol. iii. p. 210, Plate 14 , figure 3.

C. nigra nitida; vertice trituberculato, tuberculo postico majori, antennis crassis, pronoto subquadrato angnlis rotundatis; elytris parall clis striatis; tibiis latissimis planis anticis extus serratis, posticis intus versus apicem dente armatis; abdomine subtus macula nulia instructo.

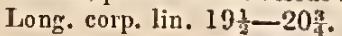

Habitat in Guinca. Mus. Nosir. Sce. D. Raddon et Savage.

The plant represented in the plate is the Stapelia divaricata from Southern A frica. 


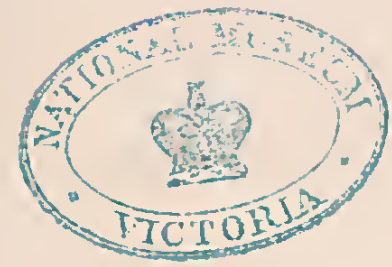




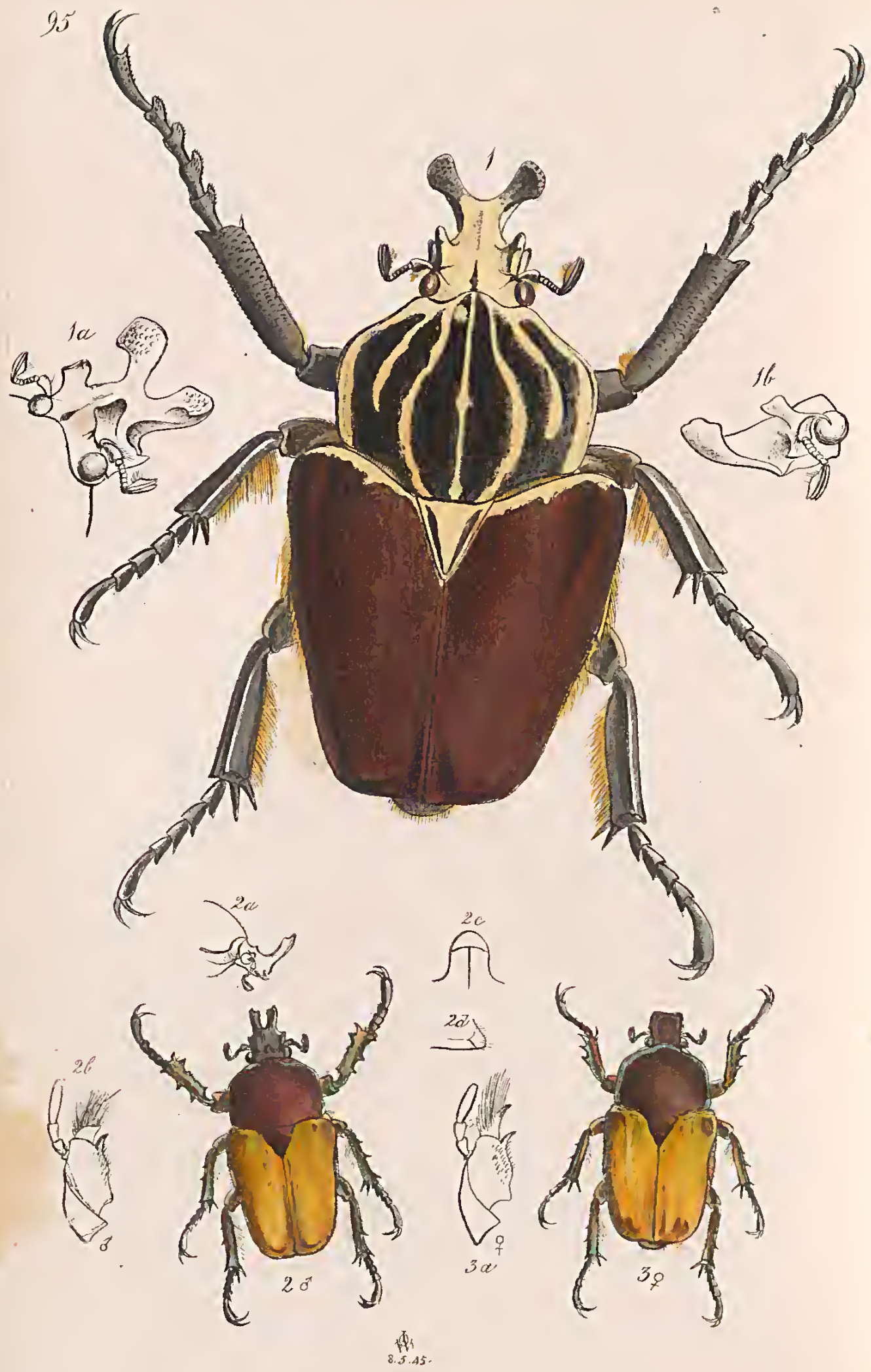




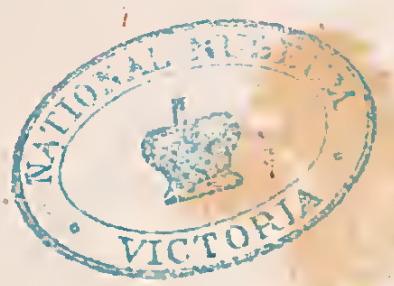


9) 4

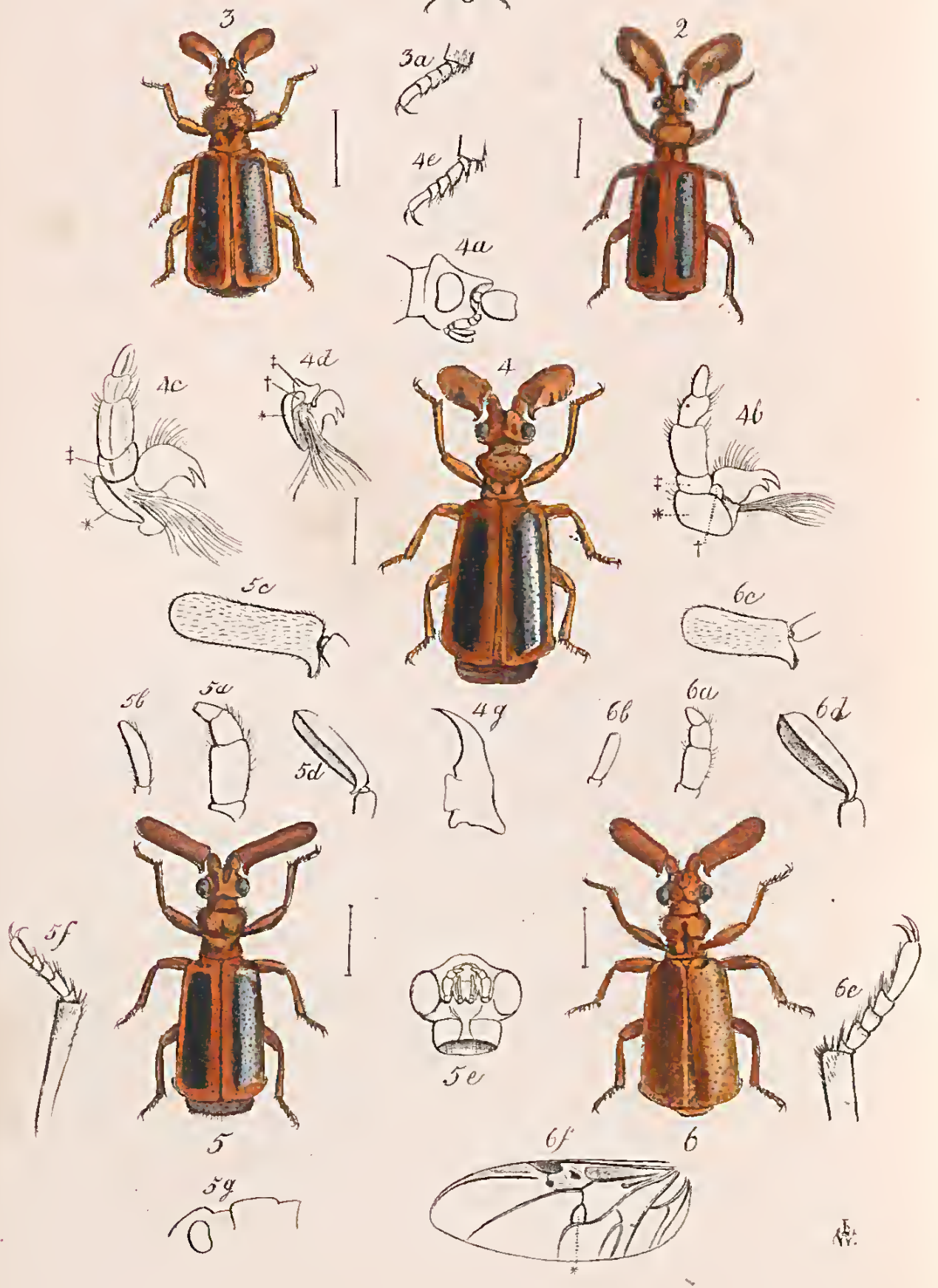


(ㄷ) 
93.
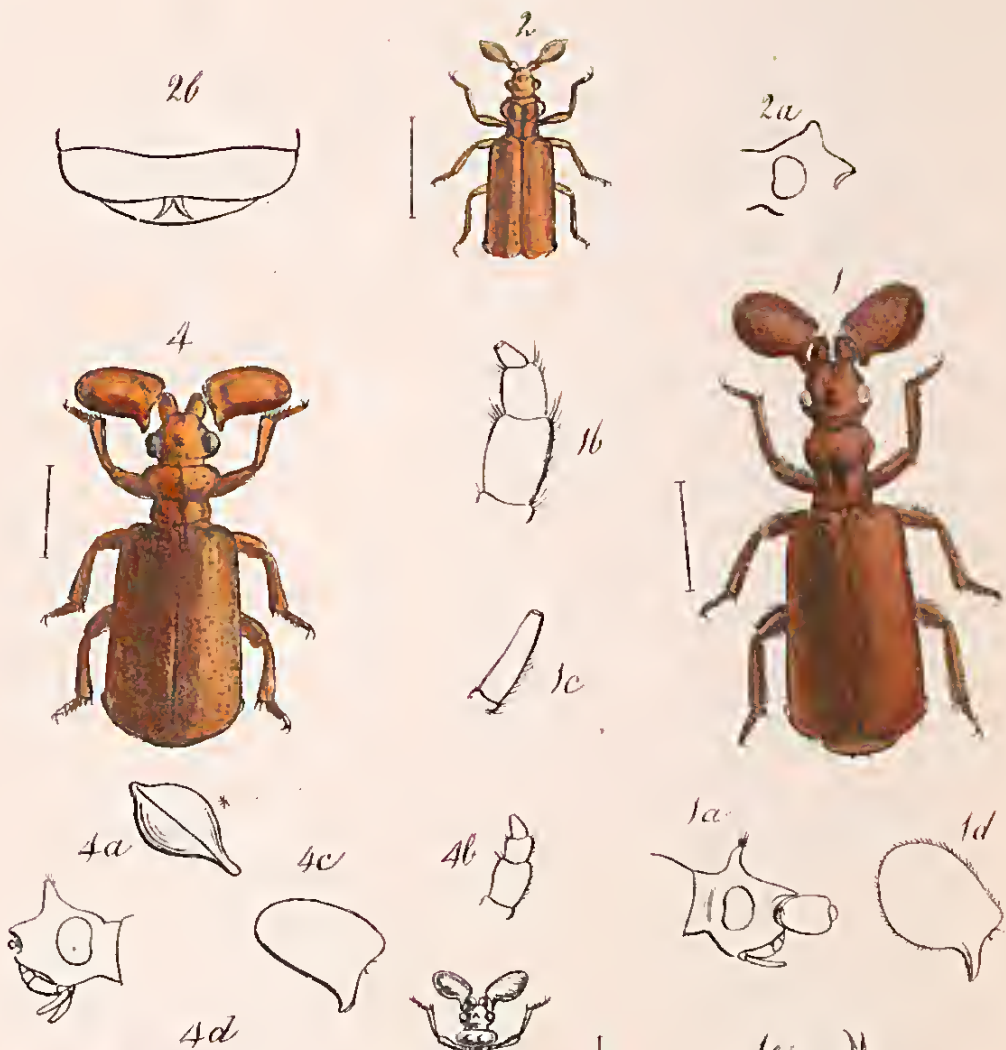

46.
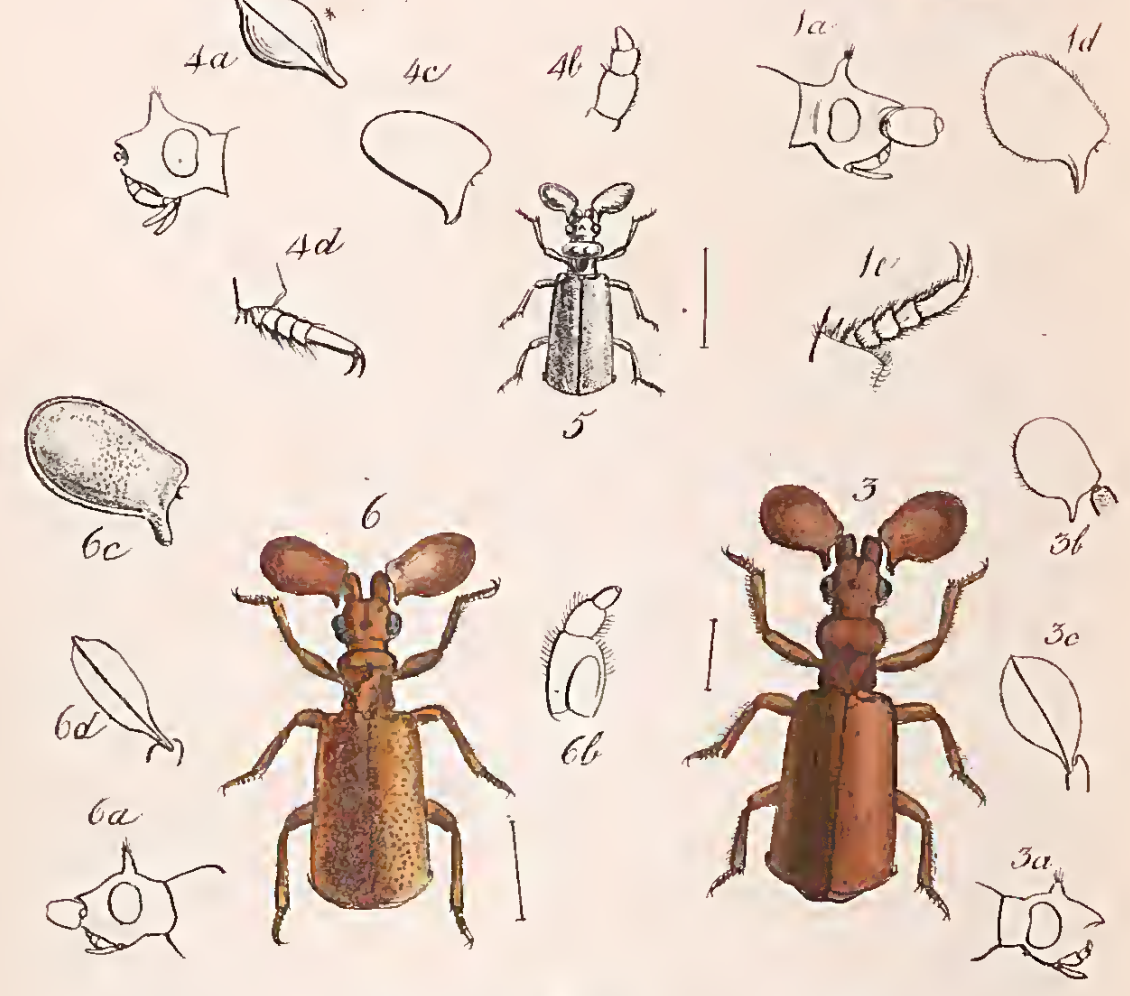

等.

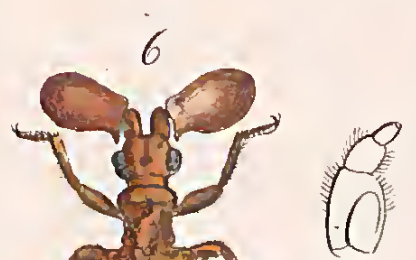
66 


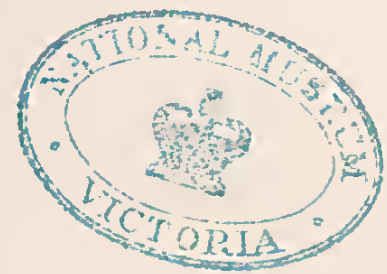


92

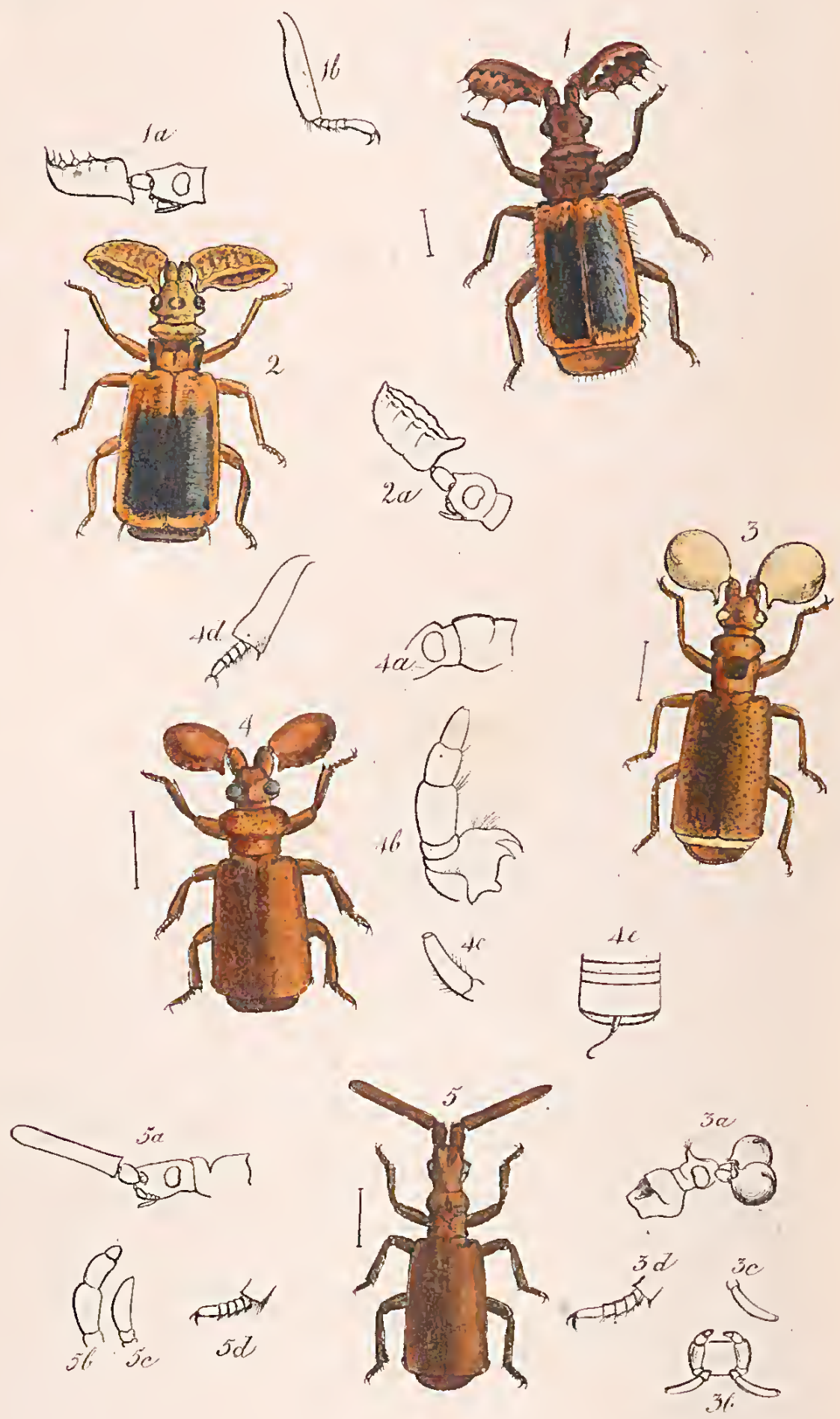





\section{9}



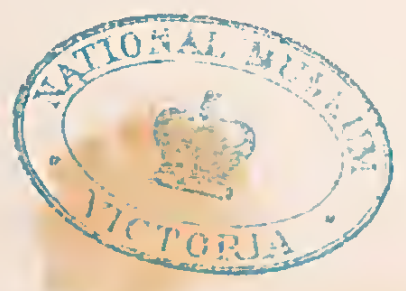




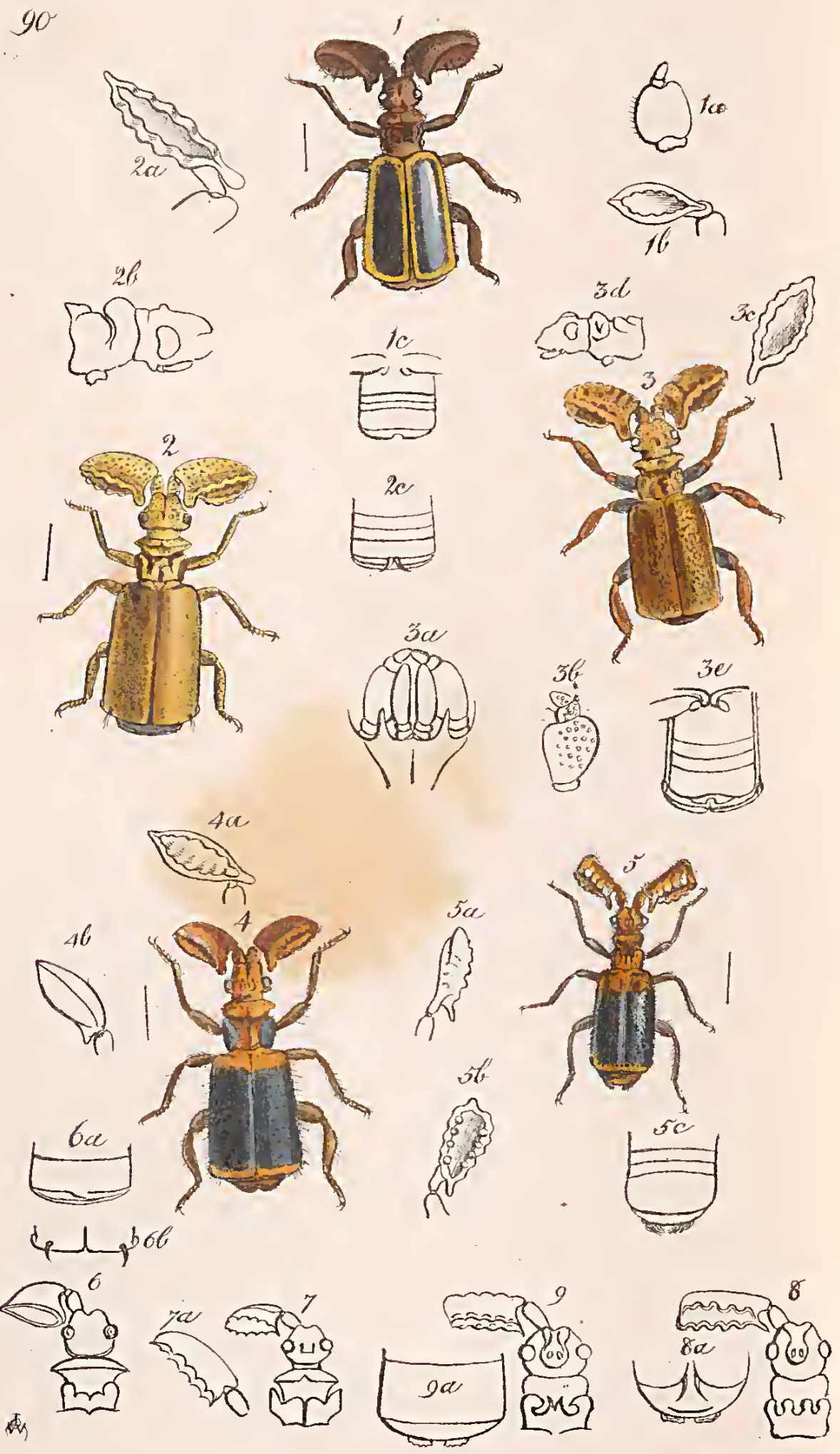




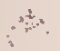

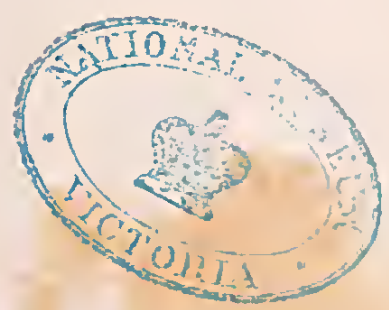




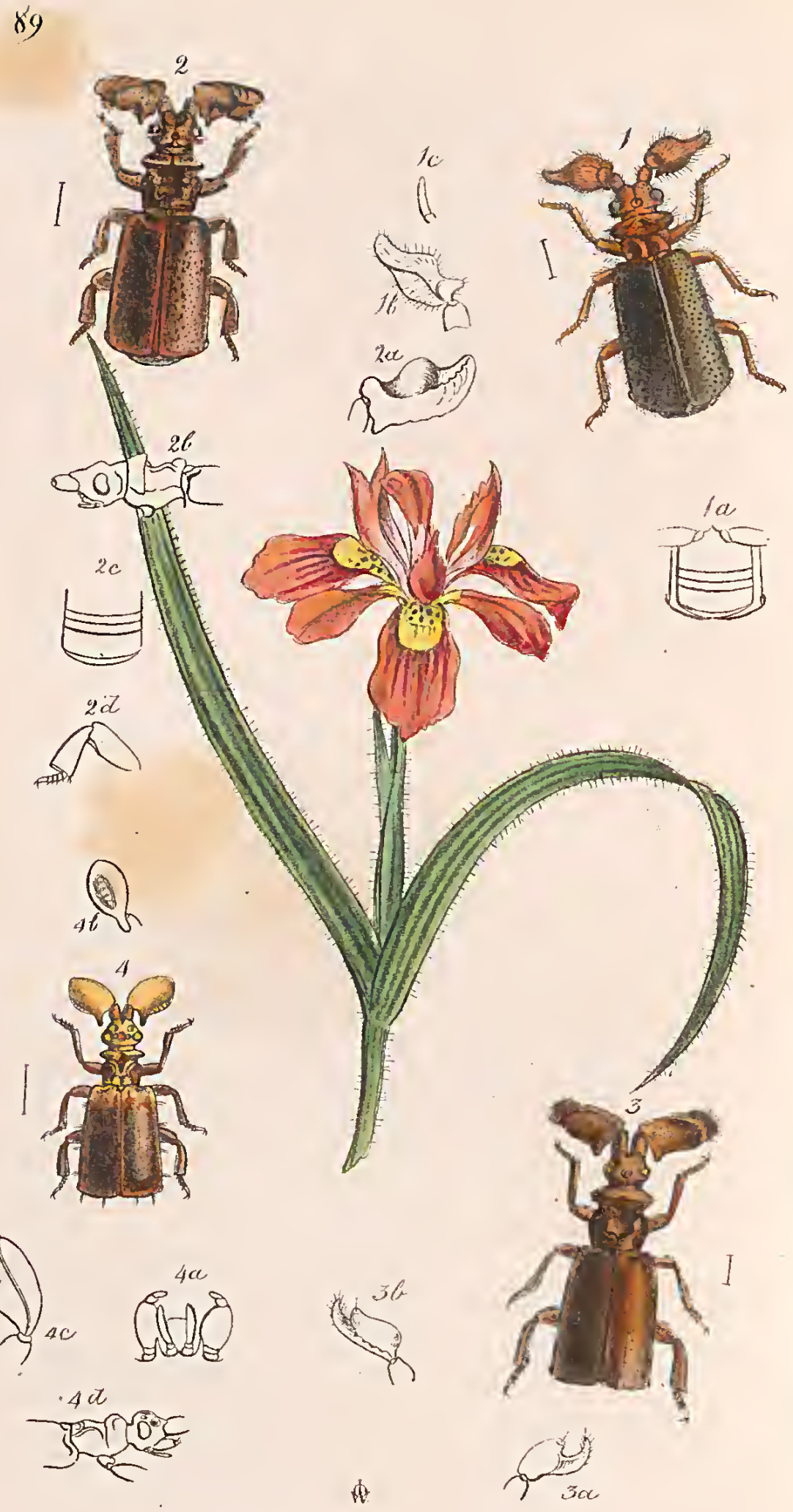





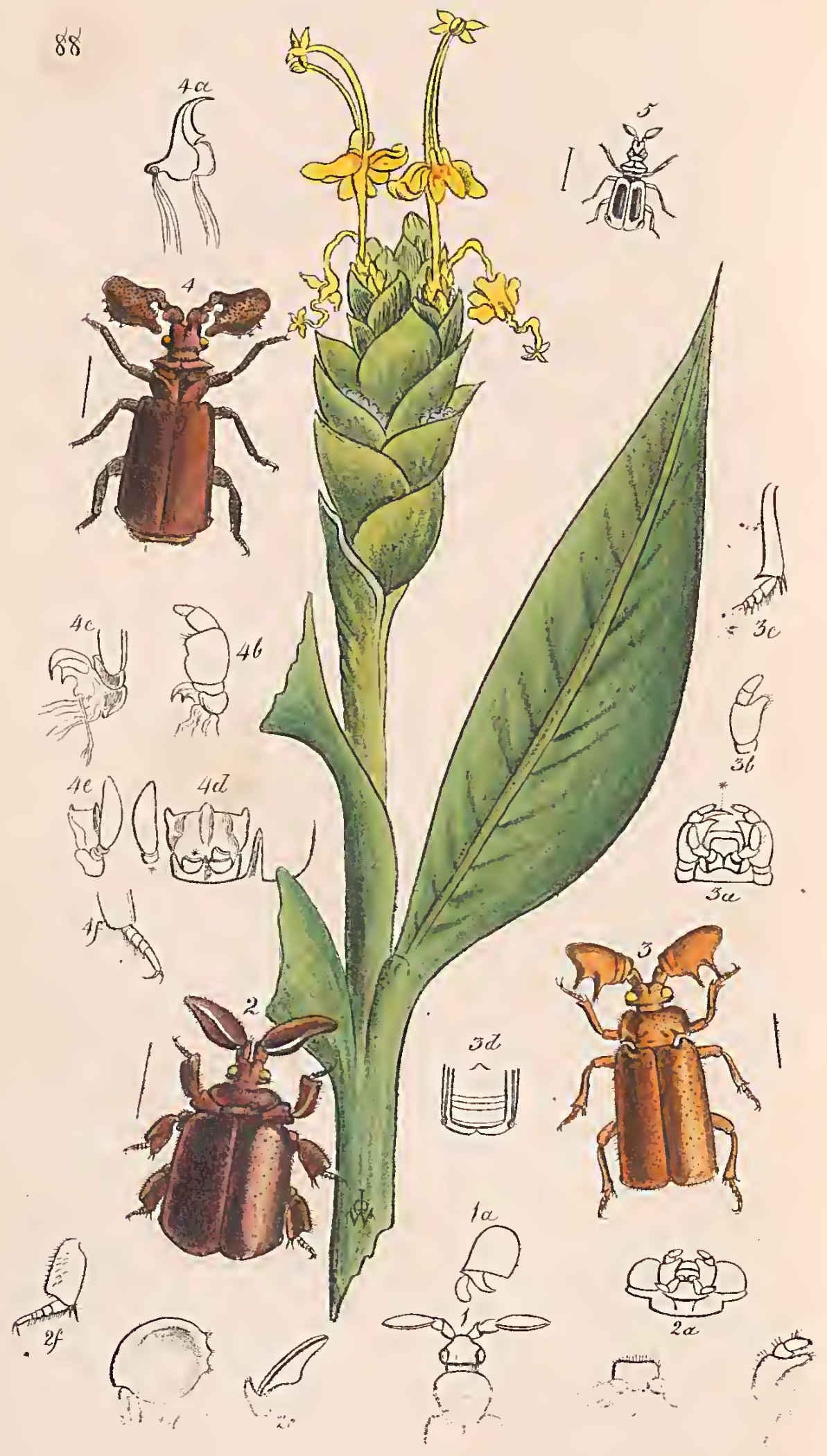




\section{PLATES LXXXVIII.-XCV. MONOGRAPH OF THE COLEOPTEROUS FAMILY PAUSSIDFE. PART IV.}

\section{Genus PLATYRHOPALUS Continued.}

Sirce the third part of this monograph was published (ante, p. 73), I lave obtained a knowledge of Captain Boys' very interesting memoir on the species of this family captured by himself in India, published in the 'Journal of the Asiatic Society of Bengal' (n. ser., No. 54); in which that gentleman has given the following description of a species of Platyrhopalus which appoars to be closely allied to $P$. acutideus.

Species VI?-Platyruopalus Suturalis, Westu.

"No. 2, Fig. 2. Mhow. July 17, 1839.-Genus Paussus. Lengुth, 6-20th of an inch; body brown, rather deeper in colour near tho sutural margin of the elytra; antennxe of two joints, the last having an elongated pedicle resembling an intermediate joint; the club is pcar-shaped when viewed from above, irregular if seen in flank; edges compressed, forming a carina, which is produced into a small tooth near the basal angle. Head has the front slightly emarginated in front and rounded, narrower than the thorax, from which it is exserted; eye rather large for the insect, rounded when seen from above, reniform when viewed on the side. Thorax cordiform, broadly truncated posteriorly, having a transverse sinus crossing its centre. Elytra narrowed anteriorly, rounded on the posterior external margin, squared on the internal onc; abdomen tumid and very like many of the Carabici I have been lately taking. Tarsi of five joints, the first of tho posterior tarsus scarcely discernible unless the foot is put in motion; last joint longest; all of them cylindrical or obconical, and furnished with a few hairs bencath.

"Note. This insect came to the lights on the table some time after gunfire last night."

From the structure of the antenna and prothorax, as represented in Capt. Boys' figure (copied in my Plate 88, 1, 1 a), I infer that this insect belongs to the present genus; although the want of details and the description of the tarsi render this opinion doubtful. 
The specific name proposed above is therefore for the present merely provisional.

Having, however, received information from Captain Boys of his having been so kind as to forward to me a number of species of this family from India, I trust to be enabled in the following number of this work to give coloured figures of this and other apparently new species described in his papcr above referred to.*

\section{Species VII.-Platyruopalus Mielit. Westw.}

(Plate 88, fig. 2.)

Pl. rufo-piceus, clytris castaneis latissimis fcre quadratis, antennarum clava compressa fero circulare, basi extcrne angulum formanti, pedibus latissimis.

Long. corp. lin. $4 \frac{1}{2}$; lat. elytr. lin. $2 \frac{1}{2}$.

Plat. Mellii, Wcstw. Linu. Trans. xvi. p. 685. Trans. Ent. Soc., II., pl. x., fig. 4. Guerin, Iconogr. Règne An. Ins, pl, 40, fig. 11.

Habitat Malabariâ. Mus. Melly, Gory, \&z.

This singular insect in its dilated form approaches the Cerapteri, but in all its essential characters it belongs to the present genus. It is subconvex, and of a rufo-piceous colour, with the upper surface of the body finely and distantly punctured, shining, very slightly setose, and with the head and prothorax lower than the back of the elytra; the head is small, rather glossy, with the anterior margin emarginate, and the hind part of the head narrowed into a neck; the clava of the antenna is very large, nearly circular, and compressed-that is, the anterior or upper face is slightly concare, whilst the posterior or inferior surface is slightly convcx, especially in the middle; the entire margin is acute, and with three very minute ciliated tubercles in the upper part of the margin a little before its extremity; the base of the clava is also produced in a somewhat square lobe at its under angle.

The maxilla are furnished with a minute filiform appendage analogous to the inner maxillary palpi of the Carabidx, which in the specimen examined by me was twisted, giving the appearance of being articulated in the middle; the maxillary palpi are large, with the second joint broad, and strongly produced at its inner extremity. The labial palpi are cylindrical, hirsute, and with the middle joint rather larger than the apical one. The prothorax is short, transverse, nearly twice as broad as the head,

In consequence of this intelligence, the publication of the following number (which will complete the Monograph of the Paussidæ, as well as the present work itself), will be deferred until after the arrival of Captain Boys's parcel. 
rather opaque, with the lateral margins rounded; the posterior portion is very short and narrow, but distinct, and separated from the anterior part by a nearly straight line. The elytra are glossy and castancous, one-third wider than the prothorax, being rather longer than broad; each is furnished at its outer postcrior anglo with a small mamillated tubercle, the sides of which are raised so as to give it the appearance of a spiracle; the femora and tibia are rery broad, short and depressed; the latter subobliquely trumcated, the fore posterior being furnished with two calcaria; the tarsi are short and cylindrical, ciliated beneath, distinctly five-jointed, the first joint being the thickest and the fourth the shortest; the basal joint in the anterior tarsi is shorter than in the other feet.

Fig. $2 a$, underside of head; $2 \zeta$, maxilla; $2 c$, labium and palpus; $2 d$ and $2 e$, antenna in different points of view; $2 f$, posterior tibia and tarsus.

Specifs VIII.-Platyrhopalus aplustrifer Westw. (Plate 88, fig. 3.)

P. depressus, rufo-fulvus antennarum clava lata fere plana externe spinis duabus acutis, prothorace brevi plano lateribus antice rotundatis postice dilatatis, angulis posticis senicirculariter emarginatis, tibiis ad apicem externe acute spinosis.

Long. corp. lin. $3 \frac{\pi}{2}$.

Plalyrhopalus aplustrifer, Westw., Linn. Trans. xvi. p. 664, pl. xxxiii., fig. 51. ILabitat Bengalia, ILus. Britann. and Testermann.

This extraordinary species was first described by me from a somewhat mutilated specimen, in the British Museum, of unknown locaily, so that I was unable to determine its legitimate situation. II. Westermann haring, however, had the lindness to forward me a specimen, contained in his fine collection, from Copenhagen, for examination, I am enabled to give a more corrcct represcntation of it, and to speak of its true relationship to the prescnt genus with decision. It is depressed, smooth, very slightly pubescent, and of a testaceous-fulvous colour; the head is short and almost rounded in front, and scarcely emarginate, convex, and with the disc entire. The antennæ are slightly pubescent, with the clava large, somewhat ovate, very compresscd, with the anterior margin slightly rounded, the apex rounded, and the outer or upper edge produced into two long and very acute spines; the space between which is strongly emarginate, and between them and the base of the clava are two small impressions which seem to indicate rudimental articulations. The mandibles are curved and acute at the tips; the maxillary palpi have the second joint very broad, and acutely produced into a strong point at the inner extremity; the labial palpi arise from 
a rather broad mentum, and have the two terminal joints of nearly equal size. The prothorax is flat, broader than the head, short, with dilated sides, the margin being rounded at the anterior angles; whilst the hinder angles are acutely truneate, or rather very deeply and nearly semicireularly emarginate, leaving a narrow posterior lobe to the prothorax nearly as in the genus Lebia. The elytra are oblong-quadrate, with the base rather broader than the prothorax, smooth, shining, impressed at the base, and of a rather brighter eolour than the rest of the body. The feet are rather slender, with the tibiæ compressed at the tips, the outer angle being produeed into an aeute spine, and the inner angle furnished with two calcaria; the tarsi are five-jointed, but the fourth joint is very minute.

Fig. $3 a$, lower parts of the month in situ; *, the nuandible; $3 b$, maxilla; $3 c$, posterior tibia and tarsus.

\section{Genus.-PAUSSUS, Linnarls.}

Cornns oblongum subdeprossum; caput mediocre prothorace angustius; antennarum clava maxima forma variabilis sæpius irregulariter obtrigona, compressa rel subdepressa basi externe in bamuus producto. Tabrum subcoriaccum parvum transicrsum angulis antieis rotundatis. Miandibulece cornete parro basi dilatata apice falcate acuto denteque in medio marginis interni motubranaque coriacea interna basali quadrata instructe. Maxilla stipite crustaceo (figs. *) processu terminali (interno) tentissiono cornco noundibuliformi, valdo arcunto et acute bidentato, spatio iutermedio membrnaceo (ct in P. Hearsiano solum inveni rudimentum partis illo cornex in tab. 68, fig. 1.0-l., pugiouo + notrte). Pal. porum maxillarium iuternorum restigia nulla detexi. Palpi maxillares (externi) 4-urticulati articulo 2 do maximo sapius ad apiecm interne acuto producto. Mentum (ut videtur) rectangulare trianguliforme (lypotheuusa antice transversa) lateribus obliquis capite coalitis, nec basi artienlatum, angulis anticis lateralibus porrectis et in dentem subacutum productis. Labrum, os itforno claudens subquadratuu corncum subplanum vel medio longitrorsun subearinatum, margine antico integro vel carina apice iu dentem parrum ecntialcm producto. Palpi labiales maxillaribus breviores labinnne longiores ad ortum subconnati (sc. interdum in scapum parvum vel radiculam * inserti ut in P. microccphalo) labïnue facicm inferiorem velantes et marginem ejus anticum ultra extensi, interdum reflexi, 3 -articulati articulis duobns basalibus brevissimis ultimo magno longe ovato aut cyliudrico, subulato, apice acuto. Prothorax subcylindricus vel truncato-cordatus paullo longior quam latior, plerumque quasi in duas partes divisus, palte antica plus minusve clevata. Scutellum parvum. Elytra prothorace latiora, oblongo-quadrata, postice truncata angulis posticis externis tubereuliferis. Peiles breves robusti plerumque dilatati; tibiis quatuor posticis sæpius bicalcaris. Tarsi 5 -articulati articulo basali sapius minuto. Abdomen 4-articulatum articulis duobus intermediis brevissimis.

In my monograph upon this family, published in the Linnæan Transations, I endeavoured, at eonsiderable length, to clear up the confusion existing in the writings of Afzelius, Latreille, and others, as to the real strueture of the parts of the mouth. Having at that

* Is it possible that this scape of the labial palpi can be the rcal represcntative of the mentuin, and that the part I have describel as the mentum is in fact part of the skull? 
time takcn out the labium of only one species of this genus, of which the anterior margin was quito simple, I was induced to believe that in describing the labium as 3-dentate, Latrcille had mistaken the two spines at the anterior margin of the mentum or gula triangularis for part of the labium. Having, however, reeently dissected P. microeephalus, which appears to have been tho species which lie disseeted (as he gives it as his first example of the gcmus, having received it from Mr. MreLeay), I find that its labium accords with Latreille's deseription. As to the part whieh I havo regarded as the mentum (a part which Latreille states is wanting), it may be eontended that the two porrecter spines represent the producel undersides of the head, or undercheeks peenliarly developed, as in Catogenus, Passandra and Megagnathus; but as the true mentum is oceasionally soldered to the heid (as in Siagona), and as the maxillae arise at tho outersides of the produced spines (thus agreeing with the typieal strueturo of the Coleoptera, whero the base of tho maxille arises at the outersido of the mentum), I have the less hesitation, espeeially after a eomparison of this part in this genus and in the preeeding, in regarding the gula triangularis as the representativo of tho wentum.

As regards tho external sexual marks of distinetion in this genus, I am only able to state, that, aeeording to Afzclius, the female of $P$. sphœroeerus differs ehiefly from tho male in having the labial palpi rutler narrower, the prodneed lobes or spines of the mentum glaueous, the maxillary palpi shorter, with the seeond joint narrower; the abdomen longer, and tho posterior femora slenderer. In some individuals, wo find the extremity of the abdomen furnished with two aeute eurved divorging spines, whieh, I believo, will be found to be a sexual peculiarity.

The species of this genus are much more numerous than those of any of the other genera. Somo of them, possessing a subcontinuous prothorax, and a broad elava to the antenna, are closely allied to the Platyrhopali; whilst othors, with a bipartite prothorax, seem to approach Pentaplatarthrus, although the strueturo of tho palpi, maxilla, \&e., of the last-named genus (see pl. 58 , fig. 2, details) materially differs from that of tho true Paussi.

Of the habits of this genus we possess but little information; suffieient, however, appears to be known to lead us to infer that the species are nocturnal in their habits, being often attraeted by the light in houses after dark, and that, like Claviger, Lomeelusa, 
\&c., they reside in ants' nests. Afzelius states of P. sphcerocerus, that having (in January, 1796) entered upon a newly-erected residence, "one evening, having just lighted my candle, and begun to write, I observed something dropping down from the ceiling before me upon the table. It remained for a little while quite immovable, as if stunned or frightened, but soon began to crawl very slowly and steadily." Several others were obtained by him in like manner, whence he "concludes that it is a nocturnal animal, that it becomes benumbed by candlelight, that it lives in wood, and prefers new-built houses." * None were taken after February. Since the days of Afzelius, other captures, under similar circumstances, have been recorded.

Captain Boys, whose attention has been especially directed to the Indian species, and who has detected eight species, states, in his memoir above alluded to, that "in flight the Paussi are exceedingly easy and agile; the lower wing, when expanded, being in comparison to the size of the insect, of large dimensions; and when they alight, the movement is so sudden, and the elytra are closed so instantaneously over the lower wings, that they appear as laving dropped down to the spot on which they rest, and where they generally remain several seconds previous to again attempting to move (facts which I have also rcmarked as practised by many Carabici). Its walk, however, entirely differs from that of this last-mentioned genus; for instead of being nimble, and occasionally rapid, I have never scen it moving but in a slow and sedate manner, at which time the antennæe aro extended to the front of the head, and to these is occasionally given an upward vibratory motion. - On being scized, they emit from the anus a very acrid liquid, accompanied by an explosion, and attended with a strong scent, resembling that produced by Brachini and other allied genera when similarly treated; and although in minuter quantities, it is abundantly sufficient to produce a very sensible heat, and the crepitation may be distinctly heard and felt. Wherever the skin has been subjected to its action, discoloration inmediately ensues, of a reddish-brown colour, which soon after turns to a brownish black, resembling the stain produced by the touch of caustic, and which remains permanently fixed for many' days after. The explosion is repeated three or four times succes- 
sively, at which periods a vapour may be observed to accompany each crepitation, attended with a strong and very penetrating odour, something like that of nitrie acid." On touehing the papillw-like tubercles at the outer angles of the extremity of the elytra (giving eover to an elongated appendage of the same description, which is attached to the upper exterior margin of the abdomen ; and whiel, by the aid of a pin's point, may be lifted up, and in a slight degree outspread, but eollapsing immediately the impediment is removed), Captain Boys observed, that "they possessed the power of diseharging a yellowish milky liquid, resembling pus in eonsisteney, and whieh speedily overspread the lower part of the elytron, granulating into small egg-shaped grains. On repeating the irritation, the same results oeeurred; and in order to be eertain of the faet, I tried each elytron twice with the same effeet; -and in all these trials, eaeh emission was aecompanied with a faint acidulous odour."

Of the speeies described by Captain Boys, one is stated to hare been eaptured on a heap of manure, a seeond was taken by sweeping high grass with a hoop net, three were taken at night, liaving been attraeted to the lights; "another was reseued from the clutches of a small black ant, whieh eircumstance I notice merely because a belief exists that the Paussi inhabit ant-hills ;" and the last was found erawling up the wall of his bathing-room.

Sinee the artiele eontaining the deseription of Ceratoderus bifaseiatus, (ante pl. 58, f. 1, p. 37,) was published, I have received a specimen of that eurious insect from my friend Colonel Hearsey, by whom it was eaptured at large during the day-time.

In the former artieles on this family in the present volume, I hare alluded to the views of $\mathrm{Dr}$. Burmeister as to the relationship of the Paussidx with the Carabida analogous to that whieh exists between the Dytieidx and Gyrinida (ante pp. 5, 10, 11, 12, 76, 80.) This relationship is eonsidered to be exhibited in the strueture of the mouth, wings, and indeed in the entire general strueture of the insect, not excepting the antennæ whieh are brought into eomparison witl those of Helluo laticornis, Ozæna orientalis, and some species of Morio.*

* Captain Boys alsu, in his Memoir on the Genus above referred to, has likewise arrived at the conclusion that these insects are related to the Carabida, "approximating in outward appearance" to many of that family, possessing also five-jointed tarsi, and possessing, like Brachinus, the power of crepitation. 
The exanination of the structure of the mouth of Platyrhopalus, which I have detailed in my former article, has produeed a result at variance with Dr. Burmeister's views, and from an investigation of the characters afforded by the wing veins of the Coleoptera, I believe it will be found that this ingenious relationship is equally unfounded; for it is to be observed that not only is the form of the wing of the Paussida quite unlike that of the Carabida and Dyticidr, but that the arrangement of the wing-veins is mueh less complicated, and the part of the wing where the fold takes place is much further removed from the extremity of the organ in the Paussidæ; it is true that like those families it possesses a small eell at the recurved extremity of the radial rein, but this can scarcely be entitled to the weight which Dr. Burmeister would give to it, since it is wanting in all the Cieindelida which I have examined,* and yet the relationship of these with the Carabidre is infinitely more decided than that of Carabus and Paussus. It is to be observed, lowever, that the genera Rlyysodes, Catogenus, Passandra, \&e., whieh I have hitherto regarded as the nearest allies of the present family, differ entirely in the arrangement of their wing-veins, the extremities being entirely destitute of longitudinal veins. The texture and general appearance of the body, the dilated antennæ having (as in the Cerapteri, \&e.) no appearance of clavation at their extremities, the form and insertion of the feet and the anomalous structure of the mouth aro, however, charaeters which I am still disposed to regard as of equal importance with those insisted upon by Burmeister. The Paussidx, in fact, are an isolated and extremely anomalous group, and whieh ever'y fresh discovery renders more perplexing to the entonologist.

The species of the genns Paussus miay, for eonvenience, be arranged in the following divisions and subdivisions:

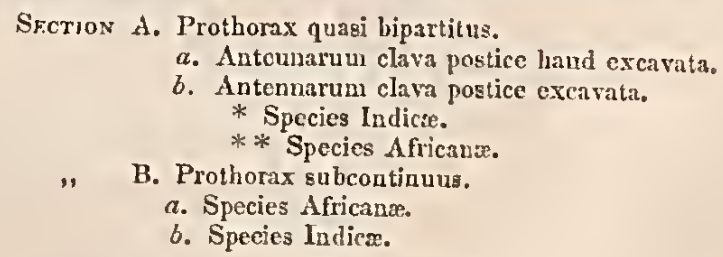

Section A. Prothorax quasi bipartitus.

Sub-section a. Antennarum clava postico haud excavata.

\footnotetext{
* This character, hitherto unuoticed, will at once vistinguish the family Cicindeliale from the Limuan Carabi, since all the sub-'amilies of the latter group possess this little cell.
} 
Spectes I.-Pavisus Michocephalus, Linnceus.

(I'late 88, fig. 4.)

Obscure niger rel nigro-piceus, clytris magis piceis vel rufo-piceis capite mutico, antennarum clava permagna, oblongo-sphseroidrea inaciualiter clevata ad basin peduneulato, peduneulo angulato, latere externo 4 -tuberculato, basi supra in uncum obtusum unidentatum producto, prothorace in medio profunde excarato parte antica strangulo distineto valde et transverse elevata, illius margiue supero acuto in medio interrupto ; tibiis liucaribus posticis paullo latioribus apice subangustioribus; abdominis apiee setis brevibus luteis utrinquo marginato. Long. corp. lin. $3 \frac{1}{3}-4$.

Exxon.-Paussus microcephalus, Linnæus (Dahl. Dissert. Acad. Bigæ ins, p. 6, tab. ann. f. 6-10; Afclius, Trans. Liun. Soc. vol. iv, tab. 22, f. 1-5.; Fabricius, Latreille, Gen. Crusi., Sce., tom. iii. p. 2 ; Westw. Trans. Linu. Soe. xvi. p. 631.

Habitat in Afica occidentali tropieali. Mus. Banks, (Soc. Liun. Lond.) MacLeay, Latreille, and Turner. (Individuum Linneanum in Musso Linnaeano haud nune invenitur.)

This is the speeies upon whieh the genus was originally established by Linnacus. Its true loeality was for a considerable period a matter of doubt, but it is now fully established as a native of tropical W Western Afriea, whenee a specimen has been lately received by J. Turner, Esq., by whose kinduess in plaeing it in my hands, 1 have been enabled to elear up several points in its strueture, incorrectly described by Afzelius.

Tho head is even on its mpper surfaee, and its front margin is slightly emarginato; the basal joint of the antennæ is terminated above in pale rounded vesienlar tubercles, and in a living state the part of the antenna bearing the four minuto tubercles is npwards, and the eurved pedinele downwards. The parts of the mouth are delineated in figures $4 a-4 e ; 4 a$ being one of the mandibles, showing the strong muscles whereby it is moved; 46 one of the maxillo, seen from beneath, and $4 c$ the same with the base of the maxillary palpi, seen laterally, showing the absenee of the analogue of the inner maxillary palpi ; $4 d$ tho labium, with the base of the labial palpi arising from tho basal seape, and having the anterior extremity terminated by three points; $4 e$ the same seen laterally showing the lateral eontinuation of the seape, and the thickness of the labium; and $4 f$ the posterior tarsus and the extremity of the tibire destitute of calearia.

\section{Species Il.-Pausus .Tousselinit, Guér.}

"Corps d'un brun foncé presque noir, a vce l'abdomen et l'cxtrénitélles ély tres ferrugineux: tête petite, ayant un sillon longitudinal cu avant ct trois tubereules cu formo do cornes sur le vertex; antennes rugueuses avee le ler articlo giand presque carré, lo second ou la massue subcylindrique, trois fois plus long que le premier, un peu rétréci au miliell, ayant en dedans et à la basc un appeudice tronqué, et, près de l'extrémité, trois fortes dents aigues, corselet divisé en deux par un profund etranglement, ayant une profonde excavation longiludinalo au milicu, et deux taches orangéos prounites par un fin duvet et placées de chqque cỏté et presque au fond de l'étranglement transversal; élytres lissés, avec uno petite dent dilatée près le l'extrémité, pattes rugucuses comme les antennes." 
" Ce curieux insecte a été trouvé au Pégou, au bord de la rivière Yrrawady, à une journée de Rangoou; il était posé sur un tronc de palmicr." -Guérin-Mcneville, Revue Zool., No. $2, \mathrm{p} .21$.

I regret that I lave not been able to obtain a figure of this species, which $I$ have not found in any of the Parisian Cabinets which I have examined. From the structure of the prothorax the present appears to be the proper position of the species.

\section{Species III.-Paussus Linnar, Westw.}

(Platc 89, fig. 3.)

Parvus subcylindricus, rufo-piceus, clytris rufescentibus antennarum clava lata subquadrata, apice valde depresso recurvo, subhirsuto; tibiis quatuor anticis angustis.

Iong. corp. lin. 2.

Halitat - ? In MIus. Soc. Linn. Lond.

Plaussus Linnai, Westw. In Trans. Linn. Soc. xvi. p. 634, pl. 33, fig. 22-24.

This is the most minute species of the family with which I am acquainted. It is preserved in the Linnaean Cabinet, being attached to the Linnæan label of the Genus, although quite distinct from the species described by Linnæus. Seen under a lens it appears very finely shagreened; the hcad and prothorax being opaque, whilst the hind part of the latter and the clytra are more glossy. The head is subconvex above, obscure, pitchy, and of a subtriangular form, but narrowed bchind the cyes; the fore margin is deeply emarginate, and between the eyes is a rather deep horse-shoe-like excavation. The clava of the antennæ is rufo-fuscous with the apex rather pilose; seen in front it is of an oblong form, rather broadest towards the base, its outer angle being slightly produced; the anterior margin has threc minute tubercles; the disc is very uncven, the apex being suddenly depressed, and reflexed, with an acute edge (figs. $3 a, 3 b$ ). The prothorax is elongated and bipartite, with the fore part broader than the head, angulated at the sides, with a transverse carina, interrupted in the middle; the hinder part is deeply excarated in the middle, with irregular margins, bearing two small tufts of luteous decumbent hairs near the contraction; the lateral margins of this part are nearly rounded. 'The elytra are broader than the prothorax, but scarcely longer than it and the head togother; they aro of a dull rufo-pitchy colour, with a slight gloss, with the apex truncated. The four fore legs are rather narrow and subcompressed; but the posterior tibia are broader and depressed. I could not observe any calcaria to those legs. The legs and antennæ are of a reddish-brown colour. 
This species is closely allied to the following, but is at once distinguished by its minute size, the want of the two porrected tubercles behind the eyes, the form of the clava of the antennæ, the want of the pale scales scattered over the body, \&c.

\section{Spectes 4.-Paussus Burmetsteri, Westzo.}

(Plate 89, fig. 2.)

Obscure eastaneo-piceus albido-squamosus; elytris magis rufescentibus; capite pone oeulos utrinque spina armato; thorace bipartito; elytris subangustis pedibusque dilatatis. Loug. corp, lin. 3.

Habitat apud Promont. Bon. Spei. Mus. Reg. Berol. Hope, Evans, Westermann.

Sr.. Paussus Burmeisteri, Westw., in Trans. Eat. Soe., ii., p. 86, pl, ix., f. 3. Paussus contractus, King MISS.

This dull-coloured insect is closely allied to the preceding, as abore mentioned; it is of a pitchy-chesnut colour, with pale scales scattered over the upper surface, and the elytra, especially towards the extremities, are of a redder hue, and destitute of gloss. The head is somewhat oval, narrowed in front, and impressed in the middle of the anterior margin, from whence runs a rounded impression towards the middle of the head; bctween the eyes is a small round excavation, within which is a minute tubercle; the head on each sidc behind the eyes is produced into a short blunt spine. The clava of the antennx (fig. $2 a$ ) is very irregular on the upper surface; the base broadly truncate, and slightly angulatcd in the middle, with the outer or upper angle produced into an obtuse point; the anterior margin with several small sinuations; the extremity rounded but slightly emarginate behind both near the basal point and apex, the middle space considerably bulging out, and bearing four minute setigerous tubercles. The prothorax is subovate truncate, rather broader than the broadest part of the head, as well as longer; near the anterior part is a deep constriction, the anterior portion bcing angulated at the sides, and formed into a transverse angulated ridge, interrupted in the middle; the hinder part of the prothorax is marked with a deep and broad sulcus in the middlc, bearing two small patches of luteous hairs at the sides in front, and having the edges of the impressed part rather acute, but irregular. The clytra are but little wider than the prothorax; they do not cntirely cover the extremity of the abdomen; they are transversely impressed at the base, and bear the ordinary tubercles at the apical outer angles. The feet (fig. $2 d$ ) are short, with the femora and tibix broad and compressed, the 
latter having the tips obliquely truncate, and the angles acute. The tarsi have the basal joint very minute, as well as the calcaria, which are almost indistinct. The abdomen (fig. $2 c$ ), in the specimens in the collections of the Rev. F. W. Hope and M. Westermann, is simply 4-jointed, without any exserted appendages. [Fig. 26 represents the front part of the body, seen sideways.]

The figure published by me in the Transactions of the Entomological Society, above referred to, was engraved from a slight sketch mado during my visit to Berlin. The present drawing is from a specimen sent to me from Copenhagen by M. Westermann for examination.

Speles 5.-Pausius nufitarsis, Sam. MS.

(Plate 89, fig. 4.)

Fulvo-flarcscens; antcnnarum articulo basali, protloracis angulis posticis, elytrorum disco pedibusque piceis; tarsis rufis, antennarum clava ovata eonvexa basi extcrne in spiuam obtusam produeto. Long. corp. lin. 3.

Habitat - In Mus. Britann.

Paussus rufilarsis, Westw., in Trans. Iimn. Soc., vol. xvi., p. 638, pl. 33, fig. 25-27.

The form of this species is comparatively short and broad; it is somewhat cylindric, and very delicately punctured, and slightly pubescent. The liead is subtriangular, porrected, and nearly as large as the prothorax, with the neck narrowed, and the anterior part truncate and slightitly emarginate; it is of a pale flavescent colour ; and in the middle, between the eyes, is a rounded excavation, having a minute round impression mil eitler side; between the eyes and the base of the antennx is also a rounded impression on each side of the head. The maxillary palpi have tho second joint very broadly ovate and compressed. The basal joint of the antennæe is pitchy, and the second pale livid-flavescent, the latter elongate-globose, rather pointed at the apex, slightly carinated along the anterior margin, with the upper angle of the base produced into an obtuse pitchy spine; the middle of the upper or linder margin, with a rather depressed oblong impression, in which are four slightly elevated transverse ribs. The prothorax is subquadrate, scarcely broader and larger than the head, and bipartite; the anterior portion fulvous-yellow, with the sides of the hinder portion pitchy; the anterior part is elevated and short; along the middle runs an angulated ridge, which is interrupted in the middle, the lateral angles subacute; the linder part is larger, 
with tho middle deeply impressed, the edges of the impression being prominent and irregular in shape, and with two rounded tubercles in the middle of the lind margin. The elytra are subcylindrical, covering the extremity of the abdomen, considerably broader than the prothorax, the hinder part being broader; they are slining, with the base reddish buff, and the lateral and posterior margins red; the dise pitchy, and very obsoletely and finely punctured, the outer and apical margins with several tufts of short, rigid, red seta. The body beneath is pale testaceous, and glossy. The feet are pitchy; the femora slightly dilated, especially in the hind feet; and the tibix scarcely compressed, except the posterior pair, which are broader than the others. The tarsi are red. The abdomen in the single specimen I have litherto seen is destitute of any external appcndages.

[Fig. $4 a$, represents the lower parts of the moutls; $4 b$, the back view of the antennre; $4 c$, front view of ditto; $4 d$, front part of body, seen sideways.]

The drawing, published with my monograph in the Linnacan Transactions, has been eorrected by a recent examination of the typical specimen of the species.

Species VI.-Paussus Pricornis, Donovan.

(Plate 89, fig. 1.)

Rufo-testaceus punctatus, elytris piceo-nigris, antennarum clava oblongo-ovata consexa apicc attenuata incurva pilis longis sparsis. Long. corp. lin. 2.

Habitat in Bengalî. In. Mlus. D. Westermann.

Srs. - Paussus pilicornis, Donovan Ins. of India, pl. Paussus, fig. ***. Westrood, Linn. Trans. xvi., p. $6 \pm 3$.

This minuto speeies laving hitherto been known through Donovan's insuffieient figure and deseription, it is witl pleasure that I now offer a drawing of it, made from a speeimen kindly sent to me from Copenlagen by M. Westermann, for that purpose. It is of a dark-red colour, with the exception of the elytra, which are pitchy black, shining and strongly punctate. The head is subtriangular, with the anterior margin notched, and with an impressed longitudinal line extending from the clypens to the middle of the crown, where is a rathcr larger circular impression; the angles behind the eyes are but slightly prominent; the clava of the antenna is very setose and somowhat reversed pear-shaped, the basal portion being almost circular, with the outer angle at the base produced into a short obtuse spine; and the apieal portion is 
attenuated and bent upwards, with a slight keel along the anterior margin and a transverse depression near the base on the upper side (fig. $1 b$ ). The prothorax is subquadrate with the anterior part broadest, constricted a little before the middle, the anterior angles rounded off, and the fore part having an elevated angulated ridge, which is broadly interrupted by a rounded depression in the middle; the centre of the prothorax is occupied with a deep transverse sulcus, and the lind part is occupied by two large raised glossy spaces separated down the middle by an impressed line; the elytra are black, with the base rather pitchy, strongly punctate, and setose. The abdomen is simple in the specimen examined (fig. $1 a$ ). The body beneath is pitchy, with the breast, legs, mouth, and head of a redder pitcliy colour.

[Fig, $1 c$ represents the labial palpus.]

\section{Speces VII.-Paussus Turcicus, Fridv.}

(Plate 88, fig. 5.)

Oblongus rufus, capite elongato opaco, prothorace transversim diviso, elytris nitidis apice

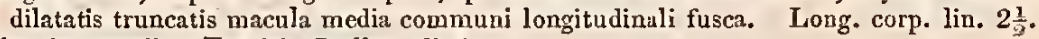

Habitat in montibus Turcicis Balkan dictis.

Srv. - Paussus turcicus, Fridvaldszky in Hungar. Trans. 1835, vol. 2, pl. 6, fig. 5 . Weslwood, in Trans. Ent. Soc. 2, p. 91.

I regret not being able to give any further particulars of this species, which from its locality must be regarded as interesting. The figure here given is copied from M. Fridvaldszky's plate.

\section{Sun-section $b$. Antcnnarum clava postice excavata.}

* Species Indicx. (I'late 90.)

\section{Specifs VIII.-Paussus 'Iibialts, Westw.}

(Plato 90, fig. 1.)

Castaneus nitidus, elytris plaga magna discoidali nigra, antenuarum clava postice (vel supra) profundè excavata marginibus vix sinuatis, tibiis posticis dilatatis compressis. Long. corp. lin. $2 \frac{3}{4}$. .

Habi tat in Bengalâ. In Mus. D. Westermann et Melly.

Srs.-Paussus tibialis, Westw. in Trans. Limn. Soc. xix. p. 47.

This very distinct species is chesnut-coloured and glossy, with the disc of each elytron marked with a large thick longitudinal blotch, leaving only the margins pitchy red. The head is rather narrower than the prothorax, nearly rounded and convex with tle anterior margin scarcely emarginate, and with an impressed line running from the middle of the clypeus to the crown; the sides of the head behind the eyes are oblique and punctured. The second joint of the maxillary palpi is very much dilated and flattened, 
being almost circular, with the inner apical angle produeed and rounded, and the outer margin setose (fig. $1 a$ ); the clava of the antenne is subovate with the anterior margin acutely keeled and rather curved, the base produced at the outer angle into a rather obtuse tooth, the lind part of the antennæe (fig. $1 b$ ) incrassated and deeply excavated, with the margins of the excavation nearly entire and setose, but marked inwardly with several small oval transverse impressions. The prothorax is rather broader than the liead, and bipartite, the anterior part with the sides obtusely angulated, and the disc transversely elevated, the middle being slightly interrupted; the hinder part of the prothorax is deeply excavated in the middle, with the edges slender and elevated. The elytra are broader than the prothorax, gradually dilated to the extremities, and of a shining black colour, with all the margins fulvous chesnut and setose; the dise very delicately and widely punctured when seen through $a$ lens. The four fore-feet are slender and cylindric, but the posterior pair have the femora and tibire dilated and compressed; the calcaria in all the feet appear to be obsolete.

[Fig. $1 c$ represents the underside of the abdomen.]

I am indebted to the kindness of Mr. Westermann for.a knowledge of this Indian species, which he forwarded for my examination from Copenhagen.

Species 1X.-Paussus rulvus, Westw.

(Platc 90, fig. 3.)

Luteo-fulrus subopacus, elytris magis rufescentibus, rivuloso-rugosis, antennarum articulo basali, prothoracis lateribus posticis, fcmoribusque obscurioribus; capite supra profunde rotundato-impresso. Long. corp. lin. 3.

Sxx.-Paussus fulvus, Westw. in Trans. Linn. Soc. xix. p. 47.

Habitat in India Orientali. In MIus. Hope ct nostr.

The lead is subtriangular, and is nearly as broad as the prothorax behind the eyes, where it is angulated to the narrowed part or neck; the anterior part is truncated and slightly emarginate, with an impressed line or gutter extending from the clypeus towards the crown, where is a large and deep circular impression with the margin elevated; it is of a luteo-fulyous colour, sub-opaque, and finely punctured. The antennæ have the basal joint punctate, and the clava is large broad ovate, depressed along the fore margin, which is slightly sinuated, the hind part of the antennæ being much dilated and deeply excavated, with the entire margins of the excaration sinuated, and the base, with the outer angle produced 
into a broad and obtusely rounded tooth. The maxillary palpi have the second joint very large, punctate, and almost subcordate; the inner apical angle beiug rounded off; the labial palpi are separated at the base by a minute conical piece or scape, as in the type of tho genus. The prothorax is bipartite, with the anterior part rather the widest, its sides being produced into rather acute angles, and its hind margin extended further backwards than in the preceding; the middle part of the prothorax is distinguished by a deep transverse impression, with the margins elevated on each side. The olytra are much wider than the prothorax, opaque and rugulose, the ruga running together very irregularly. The feet are very much punctured, compressed, and rather broad, the posterior tibire being slightly curved, and broader than the others. The calcaria * are wanting, being replaced by a few setæ, similar to those at the tips of the joints of the tarsi. The abdomen has a slight notch at the anus, but is destitute of any external appendages.

[Fig. $3 a$, represents the lower parts of the mouth; $3 b$, maxillary palpus; $3 c$, back view of antenna; $3 d$, side view of front of body ; $3 e$, underside of abdomen.]

\section{Speeres X.-Paussus Stevensianus, Westw.}

(Plate 90, fig. 2).

Pallide luteus, capitc subrugoso ; tuberculis duobus elevatis inter oeulos; antonnarum clava. magna postice excavata, marginibus excavationis sintato-tubereulatis ; clytris a picem versus fasciculis duobus minutis setarum instructis. Long. corp. $3 \frac{3}{4}$

Habitat in India Orientali. In MIus, S. Stevens.

Syn.-Paussus Stevensianus, Westw. in Lin. Trans. xix. p. 48.

This species is nearly allied to $P$. fulvus, but differs in its paler colour, narrow feet, pair of tubercles between the eyes, \&c. The head is nearly as broad as the prothorax, pale luteous, finely rugose, the posterior angles behind the eyes rounded off, with a distinct neck, the fore margin or clypous having a central notch, from whence extends an impressed line to the middle of the crown, where are two elevated tubercles excavated at the tips with a fine impressed line between each of them and the eyes. The clava of the antenna is large and strongly punctate, the anterior margin acute and curved, and the posterior considerably dilated and excavated, the sides of the excarated part being sinuato-tuber* By a typographical ertor the tibize of this epecies were described in the Linn. Trans. as
"calcaratis," instcad of "ecalcaratis." 
culated, and the basal external angle produced into a broad rounded lobe. The maxillary palpi have the second joint very broad. The prothorax is bipartite, the sides of the anterior part being acutely angulated with a transverse elevated carina, interrupted in the middle, the posterior half of the prothorax with the sides elevated and the middlo deeply impressed, the hind part having two elevated and rounded lobes in the middile. The elytra are pale luteous, somewhat shining, with the hinder part darker, very finely rugose, nearly twice as broad as the prothorax, having near each of the posterior lateral angles a small fascicle of reddish rigid setre. The legs are elongated, slender, and punctated, the posterior tibire being rather broader than the others; the tarsi distinctly fivejointed, but with the calearia obsolete and replaced by a few short bristles, similar to those at the extremity of the joints of the tarsi. The anal segment of the abdomen is furnished in the middle with two curved horny points. The head and thorax beneath are pale coloured, but the abdomen and mesosternum are darker.

Fig. 26 represents the hearl and prothorax, seen sideways; fig. $2 a$, the antenna seen from behind, showing the excavated part, with its sinuato-tuberculated margins; and fig. $2 c$, the underside of the abdomen.

Srecies XI.-Paussus Borsil, Westu.

(Plate 92, fig. 2, and pl. 90, fig. 6.*)

Lute-fulvus, antennarum clava antiee valde depressa, marginibus excarationis suherenulatis, capite supra in medio exeavatione rotunda, elytris basi apiceque exceptis nigricantibus singulo versus apicem setula instructo. Long. corp. lin. $3 \frac{1}{2}$.

Habitat in India orientali, D. Boys.

Srn.-Paussus No. 6. Boys in Journ. of Asiat. Soc. of Bengal, N.S., No. 54, p. 433, and Tab. aun., fig. 6 .

The kindness of Captain Boys in sending to me lis speeimen of this insect from India, enables me to determine its situation between P. Stevensianus and fulvus, as it possesses the rugose elytra, armed near the tip with a pair of short curved bristles of the former, and the deep eireular excavation of the head of the latter; it is also much more glossy than the latter, and its legs are very much

* The whole of the row of figures at the foot of $\mathrm{pl} .90$ are copied from the plates accompanying Captain Boys' memoir, of which he justly complains to me in lis letters, that they are very unfaithful copies of his drawings, which is ecrtainly the case, Captain B. having sent me his original figures as well as the insects themselves.

No. XXIV.,-lst JUNE, 1845. 
narrower, as is also the reflexed lobe at the base of the club of the antennæ. The following is Captain Boys's description:-

"Length 6-20ths of an incli. The antennæe are composed of two joints, of which the last is very large and in the form of a widemouthed cornucopia, being attached to the first at its basal angle. The margins of the upper side are slightly crenulated, and the upper surface is rather deeply excavated, giving this part a cuspiform appearance. Anterior and posterior margins compressed, the latter produced into a blunt recurved tooth. The sides of the club are striped with six grooved bands; the eye when seen from above appears round, of an irregular oval shape when viewed from the side. Head trigonal depressed, with a marginal excavation, but no groove on the upper part. The thorax appears as if composed of two portions, the anterior being angulated and forming a rather sharp spine on each side, with its base inserted in the posterior part; this latter portion is crenulated, with the exterior margins produced and rounded : a suleus in the form of a bracket crosses the eentre. The elytra are black, broadly patehed anteriorly with brownish sienna; the posterior margin has a faint undefined line of the same colour, which blends into the general black of the wing-cases. The follicles at the exterior margin of the elytra posteriorly are much produced, and close to them on each side is a very curious moveable spine (pl. 90, fig. $6 \mathrm{Z}$ ), slightly incurved and projecting over the latter segment of the abdomen (fig. 6 a). Body beneath a bright chesnut; head, antennæe, and thorax livid brown: all the joints in the tarsi are simple, cylindrical, furnished bencath with liairs, and of five joints in each leg, the first small, the last longest.

"Note.-Taken accidentally, while sweeping in high grass, with a net, under a Munja clump (Saceharinum Munja). On withdrawing this insect from the net, it gave two very distinet explosions, leaving the ordinary black stain on my fingers; the abdomen also sivelled very much when submitted to the hot water process." Upon being plunged into hot water, "a crepitation may be heard, and the abdomen becomes greatly distended, probably by rarefaction of air contained in vessels which give their assistance in its explosive powers, and the part retains the inflated appearance until a small perforation is made in it with a needle's point or such-like instrument, which, allowing the escape of the confined 
air, enables the abdomen to contract to its natural size. The same fact is peculiarly remarkable in many specics of Brachinus."

Pl. 92, fig. $2 a$, represents the head and antennæe seen sideways.

\section{Species XII.-Paussus denticulatus, Westw.}

(Plate 92, fig. 1, and pl. 90, fig. 17.)

Obscure-brunneo-castaneus, setosus, ely trorum disco nigricanti, capite tuberculo minuto excavato inter oculos ; excavatione clavæe antennarnm denticulata, prothorace postice latio ri. Long. corp. lin. $2 \frac{3}{4}$.

Habitat in Iudia orientali, D. Boys.

Srw.-Paussus No. 1. Boys in Journ. of Asiat. Soc. of Bengal, N.S., No. 54, p. 426, and tab. ann. fig. 1 .

I am likerwise indebted to Captain Boys for sending me his specimen of this new and very distinet speeies. The following is Captain B.'s deseription :-

"Length 7-20ths of an inch; body brown, deeper in the niddle of the elytra. Antennæ of two joints, of whieh the last is large, cuspiform, and having dentated edges, with a scallop between eaeh tooth; apex rounded exteriorly: basal angle produced, acuminate, and forming a tooth at the end of the supcrior margins. Lower portions earinated; front view resembling the bows of a boat; head light brown, rounded posteriorly, emarginate in front, sunk nearly to the thorax, and bearing a minute depression in the eentre of its upper part in the form of a diminutive horse-shoe. Eyes round when viewed from above, reniform when seen in flank. Thorax suboctagonal, with rounded margins anteriorly, angulated and scalloped at the eorner's posteriorly, biseetcd in its centre, the posterior portion bearing a strongly produecd emargination, which crosses transversely in the form of a braeket. Tarsi simple, cylindrical, the last longest, the first very small, almost invisible; of five joints in each leg, all of which are furnished with hairs beneatl ; elytra truneatcd posteriorly, of a uniform width throughout, slightly depressed; body oblong flattened; palpi conical, not very salient; maxillary ones tumid at the base and over-arehing the labials. Taken on a heap of manure at Plassie, near Ihow."

Fig. 1 a represents the head and antennæ secn sideways, and 18 one of the hind tibire and tarsi. 


\section{Species XIII.-Paussus Thoracices, Donov.}

(Platc 90, fig.4.)

Ferrugineo-tcstacens, clytrorum disco late nigricanti, antennarum clava oblouga compressa sub-trigona margine antico acito, postico vel supcro excavato, cavitate ovali marginibus crenulatis ; prothoracis lateribus anticis angulatis. Long. corp. lin. $3 \frac{1}{5}$.

Ifabitat in India orientali, Bengala, \&c. In Mus. nostr., \&c.

SYN.-Panssus thoracicts, Donovan. Epit. Ins. of Ind.t. 4, f. 芖. Westw. in Linn. Trans. xvi. p. 640 , tab. xxxiii. fig. $28-30$.

Paussus trigonicornis, Latreillc, Gen. Crust., \&c. vol. iii. p. 3, pl. 11, fig. 8 ; Schonh. Syn. Ins. 1, pt. 3, p. 19.

This species is subcylindrical, with the anterior part of the body attenuated. The head is scareely so broad as the front of the prothorax, its anterior margin is acute and emarginate, its lateral margins, as far as the eyes, nearly parallel; an impressed line extends from the middle of the clypens to the erown, which bears two small elevated curved ridges, which somewhat resemble a horseshoe, the intermediate space with two minute tubercles. The maxillary palpi have the second joint rery much dilated, but with the apical internal angle not salient; the terminal joint of tho labial palpi very slender. The antennae have the clava compressed, oblong subtrigonate, with the anterior or lower margin acute, and the posterior or upper one dilated and boat-sliaped, or exeavated into an oblong-oval cavity, filled with pale coloured membrane, and having each of its margins scalloped, each scallop marked with an impressed dot; the basal angle is produeed into an acnte point. The prothorax is bipartite, the centre very deeply exeavated, the anterior portion with the margins acutcly angulated, and with its middle part dilated behind and emarginate; the hinder part has tho sides in front considerably elevated and also angulated within. The elytra are black, subopaque, with the base and narrow apical margin of brick-red; the disc with minute linteous scales, and their sides with rigid setre standing out at right angles from the body. The feet are elongate and slender, the posterior tibix being more dilated and with the tips narrowed. The tibial calcaria are obsolete. The extremity of the abdomen is furnished with two incurved fascicles of hairs, and the anal segment is destitute of the two curved horny points.

The observation of Latreille upon this species (the name of which he unnecessarily altered to trigmicornis), "P. lineato proximus et forte varietas elytris latius nigris," appears to me to be incolrect, that species belonging as I imagine to the second section, and in 
structure being nearly allied to $P$. affinis and Hardivickii. The supposition of Donovan that this inseet and P. Fichtelii are the sexes of the same speeies is certainly incorrect.

Fig. $4 a$ represents the antennæ seen from the front, and fig. $4 b$ from behind.

\section{Species XIV.-Paussus Fichteli, Donov.}

(Plate 90, fig. 5, 8, 9.)

Testaceus elytrormm disco nigricanti, prothorace angustiori sub-bipartito, antennarum clavâ oblonga postico excavata, cavitatc pyriformi marginibus sinuato-denticulatis, capite supra profunde excavato. Long. corp. lin. 3.

Habitat iu ludia orientali (Bengala, Calcutta, \&c.) Iu Mlus. Kirby, Saunders, Boys, \&c.

Syn.-Paussus Fichtclii, Donovan, Epirt. Ins, Ind. pl. 4, f. ***. Westw. in Liun. Trans, xvi. p. 641, tab. xxxiii. fig. 31, 33. Saunders in Trans. Ent. Soc., vol. ii. p. 83 pl. ix. fig. 1. Boys, in Journ. of Asiat. Soc. of Bengal, N.S. No 54, p. 129, and tab. ann., figs. $4 \& 5$.

This speeies is most nearly allied to P. thoraeiens, from which, however, it is abundantly distinet, the general shape of the clava of the antennæ, and the number of elevations on the margins of the excavation being difforent; the keel-like anterior margin of $P$. thoracicus is replaeed by an obtuse and irregular fore-margin, the front of tho head is more emarginate in P. thoraeicus, and more distinctly quadrate behind the oyes than in this speeies, in which the impression on the erown of the hearl is much deeper and rounder than in P. thoracieus, and ineloses two mimute, elevated tubercles.

The margins of the elytra are simply pubescent, whereas they are setose in that speeies; the lateral lobes of the mentum are long and acute; the extremity of the podex (which, scen from beneatl, appears like a fifth joint of the abdomen) is furnished. with two small tufts of short, thick hairs; the legs are eomparatively long and slender.

Captain Boys deseribes two varieties of this species, whieh are evidently the sexes, ono with the two diverging enrved spines beneatl the extremity of the abdomen (pl. 90, fig. $8 a$ ), which is of an equal width throughout, and with the margins ef the exeavation of the elava of the antenna presenting the appearaneo of a screw; the other, destitute of the two eurved spines (pl. 90, fig. $9 a$ ), and having the erenulations of the prothorax, across the eentre, more deeply sculptured and foliated, with the abdomen narrowed as it approaches the thorax.

The former of these varieties, although considerably irritated, 
could not be made to crepitate; on the contrary, when touched, it simulated death by contracting its limbs. The latter variety, however, discharged its little battery with facility, discolouring testpaper, and staining the liands so strongly that it was not till the end of eighteen days that the marks were worn out. On being plunged into hot water, its abdomen became very greatly distended, as is also observed in Brachinus, \&c. when similarly treated.

The variety with the two horny ventral points was rescued by Captain Boys, "from the gripe of a small black ant, which in spite of its struggles was bearing it along with the utmost facility, holding on by one of its antennæe," thus confirming the fact of a connexion between the ants and Paussi, analogous to that which exists betwcen the former and Claviger, \&c., and lcading to a clue for the discovery and capture of othcr species.

Figs. $5 a$, and $5 b$, represent the antennæ in different positions, and $5 c$, the underside of the abdomen.

$$
\text { * * Specilis Africana. (Plate 91.) }
$$

Species XY.-Paussus excapatus, Westu.

(Platc 91, fig. 2.)

Obscure fusco-rufcscens vel castaneus, capite ct prothorace paulo obscurioribus, antcnnarum clava lata ovata basi hamato marginc antico acuto et '4-foveato, postico valde cxcavato marginibus sinuatis, capitis vertice bi-impresso, pedibus posticis latissimis. Long. corp. lin. 2.

Habitat in Senegallia, Mus. Dupont. Parisiis.

Syn.-Paussus excavatus, Westw. in Linn. Trans. xvi. p. 637, pl. xxxiii. fig. 60, 61 .
Paussus crepilans, Dupont, MSS.

The figure now published was made during a recent visit to Paris, from M. Dupont's original specimen, which still, I believe, remains unique. It is very closely allied to the next species, from which, however, its geographical range as well as several structural characters seem sufficiently to separate it.

The two oval excavations on the crown of the head are outwardly margined by two narrow impressed eurved lines, which become nearly confluent behind; the clava of the antenna is flat beneath, and much more strongly punctured than above; the hind part of the head is very finely granulated, and the elytra are smooth.

Fig. $2 a$ represents the impressions on the crown of the head, $2 l$, the antenna scen from above, and $2 c$, the same seen as in a transverse section. 
Species XVI.-Paussis ruber, Thunberg.

(Plate 9I, fig. I.)

Castaneo-ferrugincus, sub-nitidus, vix pubescens sub Iente punctatissimus; rcrtice impressionibus binis parvis ovalibus, capitc antice enarginato; antennarum clava obovali margine antico subrecto et subacuto impressionibus nonnullis transversis brevibus intra marginem; margine posticn oblongo-ovale excavato ; seriequo transversa imprcssionum in pagina ejus inferiore, angulo extcrno hasali hatnato margineque basali bisinuato, thorace bipartito parte antica in spinam eonicam utrinquo producta, parto postica longiore sed angustiore antice lateralitcr subspinoso disco profunde et irrcgulariter sulcato, pedibus subdilatatis complanatis rugose pnnetatis. Long. corp. lin. $2 \frac{1}{5}$.

Habitat apud Protn. Bon. Spei. D. Kúrebs. In Mns, Reg. Berolinensi.

SYN-Paussus ruber Thunberg, Aet Holm. 1781, p. 170. 1. Afzcl. Linn. Trans. iv. p. 272. Westw. Linn. Trans. xvi. p. 635. Trans. Ent. Soc. vol. ii., p.88, pl. ix. fig. 5 .

The above description and figure are made from a specimen in the Royal Museum at Berlin, being the only individual I lave hitherto seen of the species which approaches very close to the preceding.

Fig. 1 a represents the front of the borly seen sideways; $1 b$, the labial palpus; and $1 c$, the antenna seen from above.

\section{Spfoces XVII.-Paugsus cochlearius, Westw.}

(Plate 91, fig. 3.)

Ferrugineus subnitidus flavo-setosus, antcnnarum clava basi in spinam supra producta, valde compressa dimidio apicali dilatato eroso-cochlcario, capito antice cmarginato linea impressa ad medium (impressum) verticis extensa; menti dente centrali fere obliterato; prothorace capito vix majori bipartito, partc antica lateribus angulatis et postice elevata ; parte postica angulis ejus anticis lateralibus prominentibus, transversa, in medio valde compressa tubcrculisque duobus minutis centralibus; clytris setis flarcseentibus (in lineas irregulariter dispositis) indutis, abdominis scgmentis integris; pedibus satis elorigatis tibiis prosertim dilatatis. Long. corp. lin. $2 \frac{2}{4}$.

Habitat in Afica Australi, (P.B.S.) In Mus. Melly, Westw. \&c.

Srv.-Paussus cochlearius, Westw., in Trans. Ent. Soc., ii., p. 88, pl. ix. fig. 6.

The original specimen of this species, described by me from the collection of Dr. Hooker, has been, with great liberality, added by him to my cabinet. I have also received it from M. Dupont.

Figs. $3 a$, and $3 b$, represent the antenna seen in different positions.

\section{Specres XVIII.-Paussus Kuguri, Westw.}

(Platc 91, fig. 4.)

Niger ; capite anticc cmarginato linea impressa $\mathrm{c}$ elypeo ad verticcm extcnsa, antennis nigris punctatis, clava lateribus sub-parallelis mar ine antico fere recto et acuto, postico vern multo crassiori et in naviculam longam cxcavato cujus margo superior integer, inferior vero tuberculis 6 instructus; prothorace capite multo majori bipartito, parte antica lateribus angulatis et in medio trinsverso et acute elevata, partc postica o proedente exeavationc magna ct irresulari separata in quâ maculse 2 magnm lateralcs aureo-sericantca; elytris lavibus nitidis piccis marginibus lateralibus apicequo rufescenti-Juteis, pedibus nigris geniculis tarsisquo piecis crassis dilatatis, pari postico latiori, abdominc rufescenti segmentis integris. Long. corp. lin. $3 \frac{1}{3}$.

Habitat apud Promont. Bonæe Spei. D. Krebs. In Mus. Reg. Berol, ct nostr. Amicissinı communicavit D. Klug. 
Syn.-Paussus Klugii, Westw., in Trans. Ent. Soc. vol. ii., p. 85, pl. ix, fig. 2.

Paussus runcinatus, Klug MSS.

The tibize are destitute of calcaria, and the outer margin of the elytra is furnished with a series of curved setr. The middle tooth of the mentum is obliterated.

Fig. $4 a$ represents the labrum; $4 b$, the maxilla in situ; $4 c$, the same detached; $4 d$, the mandible; $4 e$, the labium and its palpi.

\section{Species XIX._Paussus Lathfilzin Westw.}

(Plate 91, fig. 5.)

Castaneo-brunneus, elytrorum disco obscuro, capito antice emarginato, tenuissimc punctulato utrinque propo margincm internuiu oculorum impressione parva ovali, antennarum clava elongata angustiori punctatissima postice exenpata margine infero sub-serrato, palpis maxillaribus articulo 2 do. dilatato; prothoraco capito multo majori, magis nitido bipartito, parte antica lateribus augulatis parteque postica valdc excavata maculis duabus aurcopilosis versus medium positis; clytris parum nitidis et vix punctulatis disco nigricanti luteu-setosis, pedibus obscurioribus punctatis, tibiis ecalcaratis, posticis duabus dilatatis. Long. corp. fere lin. 3.

Habitat iu Sierra Leona, Senegallia. Mus. Britann., Buquet, Norris.

Sxs.-Xiphocera brunnea Latr. inedit.

From a sketch of the specimen of this insect in M. Buquet's Collection, I was induced to believe it to be merely a variety of the former species; but having since had an opportunity of comparing my specimen of $P$. Klugii with specimens of this species in the British Museum and Mr. Norris's Cabinets, I find them quite distinct, not only in colour but in structure.

The calcaria are obsolete; the lateral margins of the elytra have a row of curved setæ, and the scgments of the abdomen are entire.

Fig. $5 a$ represents the head and prothorax, seen sideways; $5 b$, the maxillary palpus; $5 c$, the abdomen seen beneath.

Section B.-Prothorax Subcontinuus.

Subsection a.-Species Africana.

Srecies XX.-Paussus sphanocerus, Afzel.

(Plate 92, fig. 3.)

Rufo-castancus nitidus, capitis vertice in cornu conico erceto apice piloso producto; antcnnarum clava sphrica livida magnitudine capitis basi hamato, carina minuta verticis tuberculo pilifero castaneo terminata instructa, prothorace supra parum inxquali, subdepresso et vix bipartito partc antica subelevata latcribus rotundatis postice subemarginata; parte postica lateribus rectis marginc anteriori signo medio quadrato, depresso, nigriscenti posteriorique parum clevato, clytris punctatis rufescentibus; pedibus longioribus gracilioribus subrqualibus. Long. corp. lin. $3 \frac{1}{2}$.

Habitat in Sicrra Lcona. D. Afzelins. Iu. Mus. Soc. Linn. Lond.

Syn.-Paussus spharocerus Afzelius in Linn. Trans. iv. p. 270, tab. 22 f. 2-6. Sturm. Catal. mciuor ins. Eamml. pl. 4, fig, 31 .

Paussus sphcoroides, Donov. ins. Ind. sub g. Paussus.

The habits of this very distinct species have been partially 
detailed in the introductory observatious on the family (ante, p. 3), from the memoir of Afzelius, published in the 4th vol. of the Linnæan Transactions.

Fig. $3 a$ represents the head and prothorax in profile; $3 b$, the labium, maxillary and labial palpi ; $3 c$, the labial palpus; $3 d$, one of the tarsi.

\section{Specres XXI.-Paussus Armatus, Dejean.}

(Platc 93, fig. 1.)

Oblongus haud nitidus, lævis obseure rufeseenti-fuscus, capitis vertico spina erecta acuta armato; antennaruu elava rotundato-ovali marginibus acutis basi externe in spinam producta disco supra et infra convexo; prothorace capite fere angustiori, pedibus valde setulosis obscurioribus. Long. corp. lin. 5 .

Habitat in Senegallia, Sierra Leona, Gambia. In Mrus. Dupont, Saunders, Hopc, Cherrolat, \&c.

Sxw. - Pausstus armatus, (Dej.) Westw. in Trans. Linn. Soc. vol. xvi. p. 645, pl. 33, fig. 62-64; Trans. Ent. Soc. vol. ii. p. 89.

Paussus cormutus, Cherrolat in Gucrin Mag. do Zool. Ins. pl. 49.

The narrow prothorax of this insect distinguishes it from the great majority of the speeies of this genus. The very setose legs, and clava of the antennx, the latter not larger than the head and elosely punetured, the tibire furnished with two spurs, and tho abdomen with two diverging horny points at the apex beneath, are also amongst its leading eliaraeters. The head is opaque, but not distinetly punetured, and the tarsi are as thiek as the tibire. The strueture of the palpi proves that this species is a species of the present genus. The inseet figured by M. Guérin under the name of $\mathrm{P}$. eornutus, Chevrolat, is identieal with the present species, as, indeed, M. Chevrolat has sinee aseertained, the name armatus being now attached to the speeimen in his eolleetion. Figures 2, $2 a$, and $2 b$, are eopied from M. Guérin's figures; the spino of the head is, however, mueh less acute than in the speeimen represented at fig. 6.

Fig. $1 a$ represents the head seen sideways; $1 b$, the maxillary palpus; $1 c$, the labial palpus; $1 d$, the antenna; $1 e$, one of the tarsi.

Stecies XXII.-Paussus cripes, Westw.

(Plate 93, fig. 3.)

Obscure rufo-castancus, clytris magis rufesccntibus, capito oblongo obseuro punctato, nntennarum clava punctatissima setulosa, rotuudato-ovali, basi extus hamato, marginibus acutis disco utrinque convexo, prothoracc oblongo, capito vix latiori, in medio eonstricto, ct nigicanti ; parte antica elcvata linea tenui e sulco medio autice ducta, scd ad marginem anticum haud cxtcnsa, tibiis obscure castancis cxtus fulvo ciliatis vel setosis ; capite supra 
tuberculo parvo corniformi armato ; abdominis segmentis simplicibus ; elytris tenue punetatis. Long. corp. lin. 3 .

Habitat in Sicrra Lcona, D. Morgan. In Mus. Britann.

This species is closely allied to $\mathrm{P}$. armatus, from which its small size and more strongly punctate dise at once distinguish it. A single specimen is contained in the British Museum collcction, presented by the Rev. Mr. Morgan.

Fig $3 a$ represents the head seen sideways; $3 b$, and $3 c$, the antennæ in different positions.

\section{Species XXIII.-Paussus Aithiops, Blanch.}

(Platc 93, fig. 6.)

Castancus, sub-uitidus elytris magis rufesecntibus punctatis, capite ante oculos breviori, vertice spina tenui acuta setosa armato, antennarum clava ovali basi extus in spinam obtusam producto, disco subdepresso sublente punctatissimo, tibiis gracilibus 2-calcaratis, tarsis 5-articulatis articulo basali minuto, prothorace vix capite latiori medio constricto, parte postica in medio lougitudinaliter latè-impressa; abdominis basi et metasterno castaneofulvis. Long. corp. lin. $4 \frac{1}{2}$.

Habitat in Nubia, D. Botta. In Mus. reg. Paris.

Syn.-Paussus AEthiops, Blanchard in Regne An. Edit. Crochard. Ins. pl. 61, fig. 8.

The shape of the clava of the antennæ, and the habitat of the species, distinguish it from the other spccies with the head cornuted between the eyes.

Fig. $6 a$ represents the head seen sideways; $6 b$, the maxillary palpus; $6 c$, the antenna; $6 d$, the same seen sideways.

Species XXIV.-Paussus nentifrons, Dej.

(Plate 93, fig. 4.)

Totus castaneo-fulvus nitidissimus; antennarum clava brevi lata triangulari-ovata supra et infra disco in medio convexo, basi trunctata et in spinam obtusam extus producta; vertice spina erecta setigera armato; olytris punctatis, prothorace antice latcribus dilatatis capite latiori in medio profunde impresso et sulco tenui longitudinali fere ad marginem anticum cxtensa; pedibus compressis nitidis, tibiis bicalcaratis tarsorum articulo basali minuto abdominis segmentis simplicibus. Long. corp. lin. 4.

Habitat in Senegallia. Mlus. Dupont, Guérin, nostr., \&c.

Sxn.- Platyrhopalus dentifrons, (Dej.) Westw. in Trans. Linn. Soc. xvi. p. 662, 1]. 33, fig. $68-70$.

The structure of the palfi of this species proves it to belong to the present genus, and not to Platyrhopalus, in which I had at first provisionally arranged it. The form of the clava of the antennæ, and the very glossy surface of the body, separate it from the other cornuted species of the genus.

Fig. $4 a$ represents the head seen sideways; $4 b$, the maxillary palpas ; $4 c$, the antenna; * the same seen sideways; $4 d$, one of the tarsi. 
Speeies XXV.-Paussus curviconnis, Chevrglat.

(Plate 93, fig.5.)

"D'un ferrugineux un peu obscur avec l'extrémité des élytres plus pâle; tête ayant sur le vertex une pointe coniquo un peu courbéo $\mathrm{cn}$ avant, corselet divisé transversalement par un fort étranglement, nyant une profonde impression à son lobe postérieur; élytres presque lisses a vee quelques tubereules très pétits et une legère dilatation ì l'extrémité et en dehors; pattes d'unc couleur plus foncée. Long. corp. 10 mill."

Habitat in Senegallia. Mus. Cherrolat.

Sxs. - Paussus curvicornis, Cherrolat in Silberm. Rev. Ent. 4, 263 ; Guérin, Iconogr. du Regne An. Ins. pl. 40, fig. 8.

Paussus cornutus, var. Chcvrolat in Guérin Mag. do Zool. No. 49, fig. Ia, 2, 2a.

The accompanying figure and description are copied from the works above referred to, as I have not had an opportunity of examining the species, and am not therefore able to speak with precision as to its more decided characters.

Fig. $5 a$ represents the head and antennæ seen in front; $5 b$, the head seen sideways; and $5 c$, the extrenity of the abdomen beneath.

\section{Specirs XXVI.-Paussus levifrons, Dej.}

(Plate 92, fig. 4.)

Rufo-castancus, elytris magis mifescentibus; lævis nitidus latus subdcprcssus vix setosus; capite inermi, antennarum clava fere ovata depressa basi truncata externe in ungucm parvum producto margineque externo 4-subdentato; prothoraco utrinque antice rotundatodilatato; palpis maxillaribus vix dilatatis, articulo 2 do maximo; elytris punctatis capite et prothorace minus punctatis; tibiis 4-posticis 2-calcaratis, pedibus dilatato-compressis. Long. corp, lin. $4 \frac{1}{2}-5$.

Habitat in Senegallia. Mus. Reiche, Dupont, Noris.

Srw-Platyrhopalus lavifrons, (Dej.) Westw. Linn. Traus. xvi. p. 661, pl. 33, 6.g. $65-67$.

The palpi of this species, upon examination of a specimen in the collection of T. Norris, Esq., of Redvales, Lancashire, are found to agree with those of the present genus in the relative length of the joints, although the maxillary palpi are not so much dilated as in many of the species.

Fig. $4 a$ represents the head and prothorax seen sideways; $4 b$, the maxillary, and $4 c$, the labial palpi; $4 d$, one of the hind tarsi; te, the abdomen in a specimen in Mr. Norris's collection.

\section{Species XXVII. Paussus Shuerardi. Westw.}

(Plate 92, fig. 5.)

Ferrugineus ; capite longitudinaliter et prothorace transverse sulcatis, hoe subbipartito ; antcnnarum clara longa tenui punctata subcylindrica basi externe subacuto; clypco vix emarginato; hateribus capitis inter oculos ct basin antcnnarum clevatis; menti dente centrali fere obliterato dentibusquo lateralibus obsoletis, palpis maxillaribus vix dilatatis articulo ultimo uinuto; prothoracc hand capite latiori lateribus antice obtusc dilatatis parte antica elevata et in medio sulco subdivisa; clytris locvibus subnitidis; pedibus com. 
pressis haud dilatatis puuctatis setis brevibus aurantiis indutis, tarsis brevibus $\mathbf{5}$-articulatis ;

abdomiuis apice subtus spinis duabus divergcntibus armato. Long Corp. lin. 51. Habitat in Africa australi. Mus. Saunders.

This curious species is nearly allied to $P$. armatus, but $I$ am unable to distinguish any spurs at the extremity of the posterior tibiæ, which are furnished with a number of short rigid setæ.

Fig. 5 a represents the head and prothorax seen sideways; $5 b$, the maxillary, and $5 c$, the labial palpi; $5 d$, one of the hind tarsi.

\section{Species XXVIII.-Paussus Lineatus, Thunberg.}

(Plate 94, fig. 1.)

Rufcscens glaber elytrorum disco nigro, thoraco inæquali lateribus autice clovato ot utrinque 1-spinoso postice 3-forcato, antennarum clava magna, compressa apice obtusa basi externe in spinam exeunte, capite punctato marginato "Maguitudo Carabi 1 -pustulati." Thunb. Long Corp. o. fig. Thunbergi, lin. $3 \frac{1}{2}$.

Habitat ad Promout. bonx spci.

Syx.-Paussus linealus, Thunberg Act. Holm. 1781, p. 171, pl. 3, fig. 4 and 5. Fabr. Syst. Elcuth. 2.75.2. Herbst. Syst. ins. Col. vol. 4, p. 102, t. 39, fig. 7, a b. Wcstw. Linn. Trans. xvi. p. 647.

Cerocoma lineata, Fabr. Ent. Syst. 1, 2. 82.

The above is an abstract of Thunberg's characters of a species which is the only one in the genus from Southern Africa, with the dise of each elytron of a black colour.

\section{Species XXIX.-Paussus Afrinis, Westw.}

(Platc 94, fig. 2.)

Castaneo-rufus vol ferrugineus subnitidus tenuissime punctatissimus, clytrorum disco nigro prothorace supra insequali latcribus antice rotundatis, antennarum clava subovata subcouvexa, margiuibus acutis basi cxtcrne in spinam conicam exeunte, marginc postico sulcis tribus obliquis fere obliteratis; capite vix prothorace angustiori antice vix emarginato; verticc elevato et subcarinato; oly tris disco nigro vix punctatis, podice nigricanti; pedibus angustioribus tibiis subcylindricis. Long corp. lin. $3 \frac{1}{2}$.

Habitat - ? In Mns. Britann.

Sys.-Paussus affinis, Westw. Linn. Trans. xvi. p. 646, pl. 33, fig. 36, 37.

This species is very nearly allied to P. Hearseianus, but differs in its comparatively longer prothorax, the sides of which, in front, are more rounded and the disc not polished; the club of the antenna is of the length of the prothorax and has three very faint impressions towards the hinder margin, with the dise not glossy; the antennæ and legs are castaneous red, and the general colour more of a dull brick-red.

There is no locality attached to the two specimens in the British Museum collection, but in the MS. catalogue the insect is named 
linentus, and Africa given as its habitat, but probably merely on the supposition of its being identical with Thunberg's species.

Fig. $2 a$ represcnts the antenna secn from above.

Subsection $b$, - Species Asiatica.

Specifs XXX.-Paussus cogratus, Westiv.

(Plate 94, fig. 3.)

Rufo-castaneus nitidus punctatus, elytrorum singulo disco nigro, capite prothorace parnm angustiori clypeo haud emarginato, sulco tenui impresso et fere ad verticem rlucto, hoc carina medin et impressionibus duabus semicircularibus; antennarum clara suborata, capitc haud majori integrn subconvexa basi in spinam externe prodnclo; prothorace corlato-truncato parte antica capite paullo latiori lateribus rotundatis sctosis, dorso in medio impresso margine postico parnm latiori, pedibns subcylindricis, tibiis 2-calcaratis, podice nigricantí punctato tuberculisque duobus uninntis conicis distantibus instructo. Long corp. lin. 4.

Hatitat in India oricntali Bengala. M[us. M[elly et Westermann.

Fig. 3 a represents one of the posterior tarsi.

\section{Spreres XXXI.-Paussus Hearseianus, Westw.}

(Plate 94, fig. 4).

Fulvo-castaneus nitidus punctatus, clytrorum singulo disco lato nigro, capitc pono oculos carina elevata transversa in malio parum angulati alteraquo longitudinali subobsolcta mediana ad nasum ferc ducta clypeo snbemarginato; antennarum clava subovata basi cxterno in spinam conicam producta mangineque postico supra oblique 3-impresso; prothorace marginibus antico angulato-rotundatis disco pone medium valdo impresso sulcoquo tenui medio longitulinali, abdominis segnentis integris podice ferruginco nitido, tibiis angustis apice 2-calcaratis, Long. corp. lin, 4.

Hlabitat in India oricntali. Mins. Hearsey and Boys.

Srw.-Paussus Hearscyanus, Westw. in Proc. Linn. Soc. April 19, 1842. Boys in Journ. of Asiat. Soc. of Bengal N.S. No. 54, p. 427, (No. 3) tab. ann. fig. 3.

A specimen of this species was first brought home by my fricnd, Col. Hearsey, to whom I dedicated it; three other specimens wero captured by Capt. Boys at Sultanpore, Bcnares, late on the evening of the 21st of June, 1840, and another on the following ovening.

Fig. 4 a represents the head seen sideways; $4 b$, the maxilla seen from outside the mouth; $4 c$, ditto from within; $4 d$, the same seen obliquely from the outside, the parts indicated by marks corresponding with those used in the other plates of this family; $4 e$, one of the hind tarsi ; $4 f$, the antenna ; $4 g$, the mandible.

\section{Spectes XXXII.-Paussus Hardwickir, Westw.}

(Plate 94, fig. 5.)

Rufo-castanens nitidus punctatus, clytrorum singulo plaga lata longitudinali nigra, antennarum clava elongata lineari subcylindrica, basi cxtcrne in hamum producto npiceque rotundato; clypeo subemarginato utrinquo inter oculos longitndinalitor obsolete canaliculato carinaque tenui e verticc ad clypeum cxtensa, prothoracis lateribus antico rotundatis, capito haud latioribus; sulco profundo transverso in mcdio; impressiono tenui abbreviata ad margincm 
anticum hand extensa parteque postica haud sulcata ; pedibus gracilibus; tibiis 2-calcaratis podice castaneo-nigro punctato ; abdominis segmentis incrmibus. Long. corp. lin. 4 . Habitat in India oricntali, Nepaul, Almorah. 'In Mus. Britann. Hope. Boys.

Srn.-Paussus Hardwickii, Westw. in Trans. Linn. Suc. xvi. p. 619, pl. 33, figs. 39, 40. Boys in Journ. of Asiat. Soc. of Bengal, N.S., No. 54, p. 434, No. 8, and tab. ann. fig. 8.

Several specimens of this species were brouglit lome by MajorGeneral Hardwicke from Nepaul, and Capt. Boys captured two at Almorah at the end of the month of July, 1842, which came to the lights late at night, and which crepitated as strongly as the Brachini, discolouring test-paper, and emitting a strong scent of nitric acid.

Fig. 5 a represents the maxillary, $5 b$ the labial palpi; $5 c$, the antenna; $5 d$, the same seen from behind; $5 e$, the head seen from below ; $5 f$, the anterior tibia and tarsus; $5 g$, the front of the head and prothorax seen sideways.

\section{Species XXxili.-Paussus Saunnersir, Westw.}

(Plate 94, fig. 6.)

Totus castaneo-fulvus subnitidus punctatus, capite et prothorace obscurioribus, antennarum clava oblongo-ovata, basi extus in hamum setigerum producta margine acuto; capite inter oculos impressionibus duabus semicircularibus notato ; prothorace cordato-truncato in medio transverse impresso imprcssione utrinque in tuberculum parrum laterale desincnte parte antica paullo elevata, lateribus rotundatis; pedibus gracilibus, tibiis apice bicalcaratis. Long. corp. lin. 3i.

Habitat in India orientali. Mus. W. W. Saunders, F.I.S.

Fig. $6 a$ represents the maxillary, $6 b$ the labial palpi; $6 c$ and $6 d$, the antennæ in different positions; $6 e$, the anterior tarsus; and $6 f$, the wing; the * indicating the small cell alluded to in p. 168.

SPEcres XXXIV.-Paussus Sp. ined. Latr.

Of this species, the habitat of which is stated by Latreille to be the Isle de France, I am entirely ignorant.

The plant represented in pl. 88 is the Indian Globba marantina; and that in pl. 89 is the Moræa papilionacea of Linnæus, from Southern Africa.

Noте.- I find, on examining the insect described by Captain Boys (noticed in p. 161, under the name of Platyrhopalus suturalis), and which that gentleman has been so good as to forward from India for my inspection, that it proves to be identical with Platyrhopalus angustus, p. 78. The specimen has the dark mark on each elytron almost obsolete; and the description should be, "Body brown, rather deeper in colour near the lateral margins of the elytra." 


\section{PLA'TE XCVI.}

liLUSTRATIONS OF TWO SPECIES OF GOLIATH BEETLES FROM AFRICA.

\section{GOLIATHUS GIGANTEUS.*}

(Plate 95, fig. I.)

THE extreme rarity of this insect induces me to refigure it from a fine specimen recently obtained by J. A. Turner, Esq., of Manchester, from the river Gaboon, the locality of the specimen figured by Drury. The specimon now represented differs from Drury's figure in having the two lateral black marks on eacl side of the prothorax united together. 'The specific character given in my edition of Drury's Illustrations, vol. i. p. 6], requircs amending thus:-

"Corpore supra velutino prothorace nigro, lineis 7 lolosericco-albis, elytris obscuro ferrugincis basi extıcmo albo, scutello albo lineis duabus lateralibus nigris."

\section{GOLIATHUS (COMPSOCEPHALUS) HORSFIELDIANUS.}

(White in Ann. of Nat. Hist., Jan. 1845.)

(Plate 95, fig. 2 đ ; 3 \%.).

Char. Subg. Corpus supra scricenm haud nitidum. Caput maris antice coruubus duobus elevatoporrectis, apice sub-bifidis, arnatum; feminx subquadratum inerme. Maxillx utriusque sexus lobo basali cornuto; apicali in mare inermi, in femina in eornu subacutum producto. Prothorax unaris valde convexus antice in lobun rotundum productus latcribus fere rectis, feminæ magis depressus et minus quadratus. Pcdes maris robusti tibiis anticis ntrinque dentatis; femina extus tridentatis; tibiis 4 posticis in ntroque sexu spinis duabus ante medium marginis externi armatis. Processus mesosterni parum productus apice obtusus. (Fig $2 a$, head of male seen sidernys ; $2 b$, maxilla of tuale; $2 c$ and $2 d$, sternal process; $3 a$, maxilla of female.)

This new subgenus is most closely allied to Mecynorhina, but differs from it and all the other Old World Goliath beetles, in possessing two spines in the middle of each of the four posterior tibix, in which respect it approaches the New World Ynce. With the exception of the bifid front of the head, the present subgenus has no relation to Narycius and Dicronocephalus.

\section{Specifs Unied. Goliarius (Conpsocrphalus) Horsfieldianus.}

Cupreo-viridis prothorace scutelloque cnstaneo-nigris, protholace tenue viridi marginato, elytris flavescenti-viridibus corpore subtus pedibusque viridi rubro et cuprco-tinctis. Long. corp. lin. 16 of, $15 \%$.

Habitat in Abyssinia, D, Roth. In Mus. "East Ind. Comp."-Mus. Brit. et Seekenberg, Frankfort (D. Ruppell, test. D. Melly, and A. White). 


\section{ADDENDA ET CORRIGENDA.}

\section{VOLUME I.}

Page 12, Systclla, W. = Trigonopteryx, Charpcnticr. S. Rafflesii, W. = Tr. punctata, charp., teste De Hain in litt. [sed quare.]

Page 65, M. Do ITan (in litt.) considers that Opsomala gladiator belongs to the subgonns Pyrgomorpha of Serville. Its whole babit, howercr, is that of the former genus.

Page 66, De Haan (in litt.) considers Bactrophore to be nearest allied to Precilocerus and Phymatcus.

Page 100, Mastax apicalis and vitrea are considered by M. De Haan (in litt.) to be varictics of one species which he has describod in the Bijdragen, under the name of M. Agrionoides, Pl. 22, fig. 2.

Page 127, M. Schaum (Aun. Soc. Ent. France, 1314, p. 390), asserts that the femalo of Schizorhina Guerinit, is the Cetonia collata of Gory and Perch (in Silbcrm. $3,125)$, and that tho foro tibix of the males aro tridentate; " la supérieure est plus faible." I caunot, howcrer, think that M. Guérin's spccimen was thus constructed. He proposcs to form it into a ner genns named Hoterosoma.

Page 161, "Toxodera denticulata, Serv,, was uever received bero from Japa or any Dutch colonics; probably there has been a mistals at the MLuscum of Paris; it seens much rather an African insect. The horn on tho head in the Mantide seems a character of inferior valuo; Diana, Stoll (Pictipennis, Scrv.), with a horn, has the samo form of thorax and abdomen, the same colour of wingsas $\boldsymbol{M}$. urbana, Fahro, and $\boldsymbol{M}$, tricolor, Linu., without the hom. It is the sume caso, with the pointcd oyes, as Burneister cxpressed it in Germar's Zcitschrift $(2,29)$. NT. rubicunda, Stoll, 25, f. 96 , with pointed cyes, belongs to the ncighbourbood of $M$. precaria. Blepharis and Schizocephala, witl pointed oyes, are rery ncarly allied to Phyllocrania and Thespis witb rounded eycs. Tarachodes coronata, Klug, and $\boldsymbol{M}$. Oxypilus lobiceps, Bijdrag. (Pl. 17, fig. 4, 5), have both two little spines before tbe eyes; for the rest, however, tbey are very distant (vid. Bijd. p. 62). Orthodera bas sub-conical eyes (vid. Burm. ii. p. 529)."
De Haan in litt.

\section{VOLUME II.}

Pago 49, M. De Hann considers Diapherodes serricollis * to ho identical with D. gibhosa of Burmcister, and $n$. pumilio (p. 50), to be a young insect. [sed quere.]

Page 51, M. De Haan assures mo that tho horn on the head of Mr. (Blepharis) Kuhhlii, is borny as in Bl. mendica, and not folinted as in Phyllocrania.

The eame gontleman questions whether $M I$. metallica (pl. 62, f. 3), is not a varisty

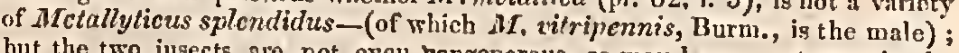
but the two insects are not evcu tongenerous, as may bo scen at onco in the form of tho prothorax, size of tho foro feet, and eycs, colour of the hind
rings, \&e.

Page 53, M. De Han considers Proscopia occidenlatis much nearer to Pyrgomorpha

Page 54, The sub-genus Cephalocema is synonymous with Astroma charp.

Pago 56, Prochilus possesses the oval foramen near the basc of the anterior tibia.

Pago 71, M. Schaum (Anu. Soc. Ent. de France, 1844, p. 401, pl. 10, fig. 1), has descrihed and figured tho female Amaurodes Passerinii, from Port Natal.

Pagc 99, M. Schanm (Ann. Soc. Ent. Fr., 1844, p. 399,) considers Inca Sommeri to be only a variety of $I$. Weberi (Trichius clathratus, Oliv. Journ. d'Hist. Nat. pl. 6, f. 2). The same author bas also described several new African species of
Heterorhina in the same Annales.t * M. C. Sommer, Esq., of Altona, assures me that he has reccired this insect direct from
Para, in Brazil.

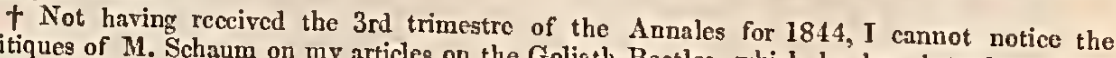
eritiques of M. Schaum on my articles on the Goliath Bectles, whicb he has introduced into
the former part of bis Menoir.

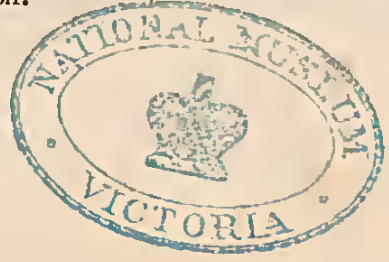








(3) 3.5 5.

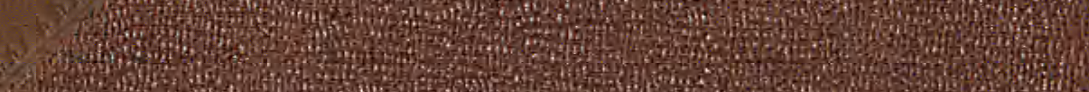

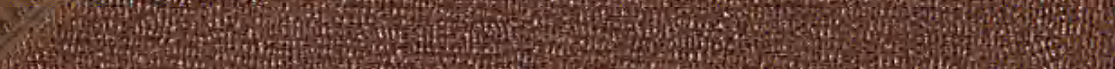
3.1. 70 .

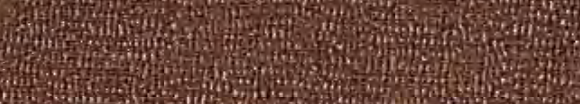
3.7.

A (3) P1. B.5. 20.

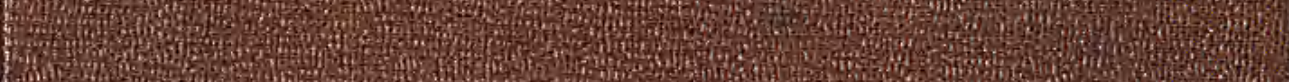
4hor 10.5. 4. 610.7. W.5. H.

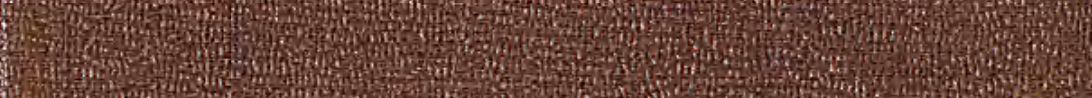
20 (1) 20. m. 20 Wor 8.7.7. 15.

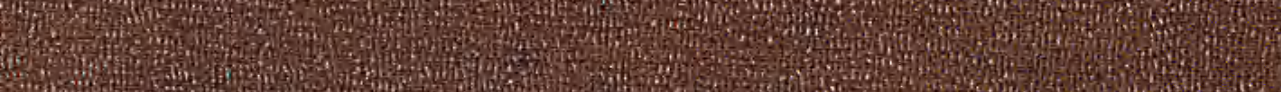

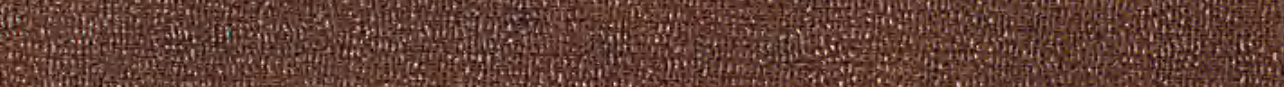
H. 0.7.

(1) H. W. W S. 